\title{
REPERTORIUM KSIĄG WIZYTACJI KANONICZNYCH BISKUPÓW KUJAWSKO-POMORSKICH PRZECHOWYWANYCH W ARCHIWUM DIECEZJALNYM W PELPLINIE
}

\author{
CZĘŚĆ III**
}

\section{G62}

\section{A. OPIS KSIĘGI}

[1.Sygn. akt.] G62.

[2.Tytuł oryg.] Visitatio Ecclesiarum decanatus Svecensis in Archidiaconatu Pomeraniae consistentium et quidem binarum parochialium in Swiekotowo et Groczno per Ipsum et Illustrissimum Excellentissimum et Reverendissimum Dominum Antonium Casimirum de Ostrow Ostrowski, episcopum Vladislaviensem et Pomeraniae, antistitem gratiosissimum. Reliquarum vero per Illrem Adm Rndum Lucam Plachecki, canonicum Lublinensem, praepositum Junivladislaviensem peracta et expedita Anno Dpmini 1766.

[3.Daty krańc.] 1766.

[4.Opis zewn.] Łac.-Pol., $2^{0}(31,9 \times 20,5)$. Kart niepaginowanych na początku księgi 2, kart paginowanych 128 , kart pustych z obciętym górnym prawym narożnikiem, ale paginowanych ołówkiem 15 . Oprawa dawna w skórę, w stanie dosyć dobrym. Pismo czytelne.

[5.Uwagi] Jest sporo wiadomości do biogramów kapłanów pracujących.

* Ks. Witold Kujawski - dr hab. historii Kościoła, prof. UMK, Kierownik Zakładu Historii Kościoła - Starożytnej i Średniowiecznej, Wydział Teologiczny UMK w Toruniu.

** Pierwszą część niniejszego Repertorium opublikowano w tomie 84 Archiwów Bibliotek i Muzeów Kościelnych, s. 93-236 zaś drugą w tomie 85, s. 149-304. 
Godne uwagi są dekrety reformacyjne, bardzo bogate w treść. Dlatego korzystając z tej księgi przy opracowywaniu poszczególnych parafii, koniecznie należy zwrócić na nie uwagę.

\section{B. ZAWARTOŚĆ KSIĘGI}

Tytuł skrócony: Ostrowski 1766, k. 1 nlb.

Tytuł pełny, jak wyżej, k. 2 nlb.

Indeks parafii dekanatu świeckiego $\mathrm{w}$ archidiakonacie pomorskim, z podaniem kart, na których poszczególne protokóły się znajdują, k. 1.

Świekatowo ${ }^{1}$. Wieś prestymonialna kapituły włocławskiej, aktualnie w posiadaniu kanonika Lasockiego ${ }^{2}$. Kościół stary, drewniany, pod wezwaniem św. Marcina. Prawo patronatu należało do kapituły włocławskiej, do której i sama wieś należała. Opis przechowywania Najświętszego Sakramentu, odnawianego co dwa tygodnie. Brak było należytego naczynia do noszenia Najświętszego Sakramentu do chorych. Chrzcielnica $z$ wodą chrzcielną i naczynia na oleje święte dobrze utrzymane. Opis stanu trzech portatyli z podaniem, jakie w nich znajdowały się relikwie. Trzy ołtarze, a z nich wielki pod wezwaniem Chrystusa Ukrzyżowanego, dwa zaś boczne, a więc Matki Bożej, przy którym było bractwa szkaplerza i trzeci św. Marcina. Ponadto w prezbiterium po stronie ewangelii był stary ołtarz z obrazem przedstawiającym ukoronowanie Matki Bożej, ale nie miał portatylu i przy nim mszy nie odprawiano. Opis pozostałego wyposażenia świątyni i jej stanu wewnętrznego, dosyć dobrego. Dzwonnica drewniana po stronie wschodniej. Zakrystia drewniana po stronie ewangelii, k. 1-3v.

Spis inwentarza, głównie paramentów liturgicznych, a więc naczyń, lichtarzy i innego sprzętu metalowego. Spis ornatów według kolorów, kap oraz bielizny i różnych innych sprzętów potrzebnych do nabożeństw. Wykaz ksiąg liturgicznych, k. 3v-5.

Opis stanu zewnętrznego świątyni drewnianej, krytej dachówką. Wieża spekniająca role dzwonnicy, znacznie zniszczona, z trzema dzwonami. Na środku sygnaturka. Cmentarz ze złym ogrodzeniem. Kostnica mała, k. 5v.

Opis sprawowanych nabożeństw w niedziele, kiedy msza poprzedzona była odmówieniem części oficjum, pokropieniem woda święcona, a kończyła się odśpiewaniem, razem z organista, modlitwy „Anioł Pański. Nieszporów nie odprawiano ani w niedziele, ani w wigilie świąt, k. $5 \mathrm{v}$.

Odpusty na Znalezienie i Podwyższenie Krzyża Świętego i na św. Marcina z zezwoleniem na wystawienie Najświętszego Sakramentu, na co był przywilej Stolicy Apostolskiej z 1764 r., k. 5v-6.

${ }^{1}$ Obecnie w diecezji pelplińskiej.

${ }^{2}$ Pewnie będzie chodziło o kanonika Ignacego Lasockiego, zmarłego w 1772 r. Biogram zob. S. Chodyński, Katalog prałatów i kanoników włocławskich, s. 481-484 [mps w Archiwum Diecezjalnym, we Włocławku]. 
Bractwo Szkaplerza Najświętszej Marii Panny, zaprowadzone w 1746 r. przez zakon karmelitów, co potwierdziła w 1747 r. władza diecezjalna, k. 6.

Opis dokładny uposażenia kościoła i parafii z dokładnym wyliczeniem gruntów, także i tych, które należały do organisty, k. 6-7.

Dokładny wykaz inwentarza gospodarczego, k.7-7v.

Wsie parafialne z których pobierano meszne: Świekatowo, Zalesie, Błądzin, Krupocin, Szewno, Tuszyny, Łąkie Niemieckie, Łąkie Młyn i Branica. Z takich wsi jak: Lipienica, Ostrowitko, Huta, Stempiska, Widliska, nowe kolonie, których nazwy nie podano, Reta Nowa, Szewinko, Grabowiec, czyli Obojki, mesznego nie oddawano. $Z$ wizytacji z $1746 \mathrm{r}$. wynika, że parafia straciła kilka wsi na rzecz parafii sąsiednich. Proboszcz nie miał prawa propinacji, ale z karczmy dworskiej płacono mu rocznie 50 groszy, o czym informowały wizytacje biskupa Gniewosza z 1649 r. i Czapskiego z 1746 r., k. 7v-8.

Wykaz zapisanych sum na parafię, k. 8 .

Luteranie oddawali iura stolae parafii, według panujących zwyczajów, chowali zmarłych na cmentarzu, k. 8-8v.

Witrykusami byli Wojciech, sołtys ze Świekatowa i Jan Piotrowski. W ostatnim roku ochrzczono 22 osoby, zaślubionych było 9 par, zmarłych 8. Parafia liczyła 183 mężczyzn 202 kobiety, 60 chłopców i 64 dziewczęta. Wszystkich parafian było 516 osób $^{3}$. Liczne luteran oblicza się na 399 osób, k. 8v.

Proboszcz Grzegorz Brankmsciszewski ${ }^{4}$, k. 8v-9.

Dekret reformacyjny, podpisany za biskupa ordynariusza przez Łukasza Płacheckiego, kanonika lubelskiego i prepozyta inowrocławskiego, sekretarza, k. 9-10.

Groc z no. Wieś kapituły gnieźnieńskiej. Kościół murowany, w stanie dobrym. Prawo patronatu należało do kolegium wikariuszy gnieźnieńskich. Parafia inkorporowana do tego kolegium w 1354 r. przez arcybiskupa Jarosława ze Skotnik, za zgodą biskupa włocławskiego Macieja z Gołańczy. Świątynia pod wezwaniem św. Jana Chrzciciela. Opis stanu wewnętrznego świątyni. Wykaz znajdujących się relikwii oraz opis pięciu ołtarzy, chorągwi, obrazów i wyposażenia. Zakrystia po stronie ewangelii, k. 10-11v.

Spis inwentarza, naczyń liturgicznych i pozostałych sprzętów, szat liturgicznych, bardzo dokładny, k. 11v-14.

Opis stanu zewnętrznego świątyni i cmentarza, k. 14.

Zabudowania plebańskie, plebania, dom dla organisty i budynki gospodarcze. Opis gruntów parafialnych i innych zabudowań. Parafia miała dwa łany ziemi miary chełmińskiej. Według dokumentu inkorporacyjnego powinny być jeszcze dwa łany, zwane Wszanum, ale jak powiada wizytacja z 1597 r. miał je przywłaszczyć sobie Konarski, dziedzic Topolna. Do tej parafii należą dwa kościoły filialne, w Topolnie i w Polednie. Dziedzic z Topolna powinien płacić proboszczowi z Gruczna rocznie 12 florenów pruskich, jak to wynika z zachowanych akt, zaś z Poledna, gdzie był dawniej kościół pod wezwaniem Wszystkich Świętych, właś-

\footnotetext{
${ }^{3}$ Podana liczba nie zgadza się ze szczegółową specyfikacją.

${ }^{4}$ Lekcja niepewna.
} 
ciciel Konopacki, innowierca, nic nie oddawał, chociaż były tam cztery łany. Tak więc praktycznie proboszcz z Gruczna z tych uposażeń nic nie otrzymywał. Organista miał swoja ziemię oraz otrzymywał jeszcze 24 floreny pruskie, k. 14-15v.

Wykaz zapisanych sum, k. 15v-16.

Wsie z których proboszcz pobierał meszne: Groczno, folwark i kmiecie oraz młyn, Parlin, Żurowo, Małaciechowo, Bagniewo, Łuszkowo, Więckowo, Poledno część królewska, Poledno część ziemska, Dworzyska, Kossowo, Krystkowo, Niedźwiedź, Kępa Krystkowska, Parowa Łuszkowska, k. 16.

Inwentarz gospodarczy, k. 16v.

Służba Boża w świątyni. W parafii, chociaż ogólnie katolików było więcej, to we wsiach Dworzyska, Niedźwiedź, Kossowo, Krystkowo, Kępa Krystkowska, Małaciechowo i Parowa Łyszkowska, mieszkali sami akatolicy. Kaplica prywatna we wsi Parlin, należącej do Pawłowskiego, k. 16v.

Proboszcza nie było, a jedynie wikariusz stały, Wojciech Woldański, ustanowiony w 1745 r. Miał on swojego wikariusza, Michała Świetlickiego, k. 16v-17.

Dekret reformacyjny, podpisany imieniem biskupa Antoniego Kazimierza Ostrowskiego, przez Łukasza Płacheckiego, kanonika lubelskiego i prepozyta inowrocławskiego, sekretarza, k. 17-18v.

S e r o c k. Wieś królewska, z przywileju królewskiego w posiadaniu Ignacego Tuchołka, starosty jasieńskiego. Kościół drewniany, od fundamentów naprawiany przez aktualnego proboszcza w 1742 r., a zbudowana przez Franciszka Tuchołka, staroste jasieńskiego w 1689 r., pod wezwaniem św. Judy Tadeusza, patronatu królewskiego. Na światło przed Najświętszym Sakramentem był zapis, 500 florenów pruskich, Katarzyny z Rozrażewa Tuchołczyny. Drugi zapis na ten cel, w sumie 300 florenów pochodził od Jana Taksińskiego z 1732. Sumę tę, wziąwszy od aktualnego proboszcza, Bartłomieja Trochowskiego, Ignacy Tuchołka, ojciec obecnego właściciela, umieścił na swoich dobrach na pięć procent. Opis ołtarzy, obrazów i sprzętów znajdujących się wewnątrz świątyni. Zakrystia murowana po stronie północnej, należycie wyposażona. Stan zewnętrzny kościoła. Dzwonnica drewniana $\mathrm{z}$ dwoma dużymi dzwonami. Była kostnica. Cmentarz ogrodzony, k. $18 \mathrm{v}-19 \mathrm{v}$.

Bractwo różańcowe, założone w 1686 r. przez prowincjała dominikanów Kandyda Zagorowskiego. Posiadało ono zapisany fundusz 600 florenów pruskich zapisanych przez Powalskiego, sędziego ziemskiego ze Świecia i 200 florenów przez Bartłomieja Pawłowskiego, pełniącego role kuratora (proboszcza) w Świeciu. Bractwo miało swoje modlitwy i msze za zmarłych członków, k. $19 \mathrm{v}-20$.

Spis rzeczy „świętych”, a więc naczyń i pozostałego sprzętu srebrnego i innego, Szat liturgicznych według kolorów, bielizny, ksiag liturgicznych i innych przedmiotów ruchomych, k. 20-22.

Opis zabudowań plebańskich, także gospodarczych i tych znajdujących się na poszczególnych gruntach, gdzie mieszkali wieśniacy. Wykaz gruntów parafialnych. Zobowiązania ciążące na proboszczu., k. 22-24.

Wykaz wsi i folwarków, z których oddawano proboszczowi meszne, k. 24v. 
Wsie parafialne: Łowenek, Łaszewo, Łowen, Nieciszewo, Brzeźno, Jasiniec ${ }^{5}$ Zamkowy, Glinki, folwark Stary Jasieniec, Kurpiszewo, młyn zwany Kręgiel, i młyn Jasienecki, folwarki Cierplewo, Wielonek, Lubonia, Lipiny oraz osada Smolniki w lasach starostwa. Do sakramentów było zobowiązanych 505 osób z kartą i około 50 osób bez karty ${ }^{6}$. Księgi metryk ochrzczonych zaślubionych i zmarłych spisywano i podczas wizytacji zostały podpisane, k. 24v-25.

Inwentarz gospodarczy plebanii, żywy i martwy. Aktualny proboszcz, który nastał tu w 1732 r. uzupełniał spis o nowe rzeczy, k. 25-25v.

Kaplice prywatne we wsi Brzeźno i we wsi Łowenek. Luteran było nieco ponad 50 osób, k. 25v.

Proboszcz Bartłomiej Trochowski, kanonik kruszwicki ${ }^{7}$ i oficjał bydgoski, od 1758 r. zwoływał tu kongregacje dekanalne (czyli został tez dziekanem), rezydujący przy swoim kościele. Organista Baltazar Radzyński, będący jednocześnie kantorem, rektorem szkoły i zakrystianinem. Witrykusi Jakub Powski i Piotr Kot. Akuszerki wystarczająco pouczone. W przytułku przebywały 4 osoby. Wikariusz Jan Kręciszewski, od 1759 r., k. 25v-26.

Dekret reformacyjny, k. 26-30.

Ś w i e c i e. Miasto (civitas) królewskie, oddane Antoniemu Jabłonowskiemu, wojewodzie poznańskiemu i staroście świeckiemu. Kościół murowany z cegły, którego prezbiterium pochodzi z czasów krzyżackich, zaś nawa została zbudowana z fundacji Konopackich, pod wezwaniem św. Stanisława biskupa i męczennika. Prawo patronatu należało do króla. Opis stanu wnętrza świątyni. Wykaz znajdujących się relikwii oraz przywilejów odpustowych. Odpustami cieszyły się też bractwa: różańcowe i św. Anny, św., Izydora, Przemienienia Pańskiego i św. Barbary. Opis jedenastu ołtarzy. Fundamenty świątyni dobre, ściany pobielone. Jedenaście okien dużych i osiem małych. Wyposażenie w meble kościelne. Organy 21-głosowe na chórze. Stan zewnętrzny świątyni. Zegar na wieży konserwowany przez magistrat, k. 30-32v.

Spis rzeczy „,́więtych”, to znaczy srebrnych i metalowych naczyń liturgicznych, innego sprzętu, relikwiarzy, krzyży. Spis obrazów i wotów przy nich się znajdujących. Dokładny opis ołtarzy, k. 32v-34v.

Pozostałe sprzęty kościelne z mosiądzu i cyny. Baldachimy, chorągwie. Opis organów i innych instrumentów muzycznych. Księgi znajdujące się na chórze, jako pomoce dla śpiewaków. Bielizna kościelna i ornaty, według kolorów. Kapy według kolorów, antepedia i obrazy, k. 34v-39.

Zabudowania plebańskie dokładnie opisane, Przytułek dla ubogich i szkoła parafialna, k. 39-40v.

Wykaz uposażenia parafii w role, łąki oraz spis inwentarza, k. 41.

\footnotetext{
${ }^{5}$ Raz pisano Jasiniec, a raz Jasieniec.

${ }^{6}$ Trudno powiedzieć co to znaczy. Może już wtedy zaprowadzano, później szeroko stosowany zwyczaj wydawania kartek.

${ }^{7}$ Biogram tego kanonika zob. A. Fiutak, Prataci i kanonicy kruszwiccy, s. 116 [mps w Archiwum Diecezjalnym we Włocławku].
} 
Szczegółowy wykaz wszelkiego rodzaju zapisów na cele kościelne w Świeciu, częściowo ujęty w wykazy tabelaryczne, ukazujące fundatora, dobra na których zostały zabezpieczone, sumę i przeznaczenie, k. 41-45v.

Odpis dokumentu zapisu sumy 2500 florenów, zapisanych w Starogardzie 15 VI 1750 r., k. 45v-46v.

Wykaz wsi z których pobierano dziesięcinę lub meszne, k. 46v-47v.

Wykaz dokumentów dotyczących przywilejów i praw kościoła w Świeciu, k. $47 \mathrm{v}-48$.

Bractwa aktualnie się znajdujące: Świętej Trójcy, czyli literatów, założone przez bpa Macieja Łubieńskiego w 1638 r., św. Anny, Różańcowe i św. Izydora. Wszystkie bractwa posiadały uposażenie i przywileje, tu opisane, k. 48-48v.

Spis cechów rzemieślniczych, które opiekowały się swoimi ołtarzami, przy których odbywały się nabożeństwa za zmarłych członków cechów, k. 48v.

Miejscowości parafialne: Miasto Świecie i wsie: Przechowo, Przechówko, Kozłowo, Skarszewy, Sulnowko, Sulnowo, Mursk, Czaple Wielkie, Czaple Małe, Wiagg, Stwolno Polskie, Dziewięć Włók, Stwolno, Bratwin, Ostrow, Sarławicem, Michale, Święte Małe, Święte Wielkie, Marzy Nowe, Marzy Stare, Miszek, Nowa Kolonia, Dzikowo, Kempa Surowa, Nowodobre, Rypa Jedwabka ${ }^{8}$, k. 48v-49.

Porządek nabożeństw, k. 49-49v.

Wikariusz Michał Witkowski od 1764 r. Było osobne uposażenie na kapłana kaznodzieję, z zapisu mieszczan ze Świecia Sobańskich i innych. Aktualnie obowiązek ten spełniają zakonnicy franciszkanie bernardyni ze Świecia (za miastem), ale mogą być zawsze przez proboszcza magistrat zwolnieni i przyjęty ktoś inny. Organista Michał Brąszwikowski, pobierający ze zwyczaju zapłatę z magistratu. Kantorem był Franciszek Żukowski. Szkoły nie było, bo lokal jej był zniszczony, ale nauczyciel niemiecki w swoim jezyku, uczył około 20 dzieci, także polskich. Zakrystianin Wojciech Burczykowski. Witrykusi Franciszek Wejdlich i Jan Kaczorowski, ale ten pierwszy ostatnio zrezygnował i niedługo będzie wybrany następca. Akuszerki były wystarczająco przygotowane, k. 49v-50v.

W parafii byli luteranie i menonici, czyli anabaptyści. Ich powinności w stosunku do parafii świeckiej określała ugoda z 1725 r. zawarta przez ówczesnego prepozyta Walentego Aleksandra Czapskiego, kanonika poznańskiego. Opis innych powinności z niektórych dóbr, k. 50v-51v.

Do parafii należały kościoły w Sartowicach i Świętem. Była też dawniej świątynia we wsi Michale. Rektorem kościoła w Świeciu i zarządcą w Sartowicach był Jan Maurzycki, k. 51.

Dekret reformacyjny, k. 51-55.

J e ż ew o. Wieś należąca do biskupa włocławskiego, ze świątynią, której prezbiterium było murowane, zaś nawa drewniana, ale już znacznie zniszczona. Nosiła wezwanie Najświętszej Trójcy. Prawo patronatu należało do biskupa. Opis wnętrza świątyni, przechowywania najświętszego sakramentu, chrzcielnicy i ole-

\footnotetext{
${ }^{8}$ Lekcja niepewna, może Wyspa Jedwabka.
} 
jów. Wykaz odpustów. Relikwii, poza portatylami nie było. Bractwa Świętej Trójcy i św. Walentego, k. 55-56.

Opis czterech ołtarzy i ich wezwań oraz stanu wewnętrznego i zewnętrznego świątyni i jej wyposażenia. Wykaż argentariów i pozostałych paramentów liturgicznych., k. 56-57v.

Zabudowania plebańskie i ich stan. Opis gruntów parafialnych, ogrodów i inwentarza gospodarskiego, k. 57v-60.

Wykaz wsi, skąd pobierano dziesięcinę, k. 60-60v.

Wsie parafialne: Jeżewo, Busna, Busienki, Nowa Wieś, Chuta, Taszewo, Białe, Piekarki, Lipna, Laskowice, Buczek, Belno, Orłowo, Bydlanko, Lipienki, Krompiewice, Skrzynki, Czersk, Lęgowo, Kwiatki, Jaszcz, Skrzydłowko, Hotowka, Długoleszcze, Wężowiec, k. 60v.

Porządek nabożeństw, k. 60v.

Organista, Jan Trzęskawski, rektor kościoła Józef Pączkowski, od 1763 r., k. 61 .

Dekret reformacyjny, k. 61-64.

O s i e. Wieś w starostwie świeckim, aktualnie w dożywociu księcia Jabłonowskiego, z kościołem drewnianym, obity, balami, pod wezwaniem Świętego Krzyża. Stan wnętrza świątyni, przechowywania Najświętszego Sakramentu, chrzcielnicy i olejów. Wykaz przywilejów odpustowych. Bractwo Różańcowe, zaprowadzone 1746 r., staraniem ówczesnego proboszcza Michała Połężka, z zapisem 500 florenów na mieście Świecie, k. 64-65.

Opis trzech ołtarzy i ich wezwań. Stan wewnętrzny i zewnętrzny świątyni oraz jej wyposażenia. Wykaz argentariów i pozostałych paramentów liturgicznych, k. 65-66v.

Zabudowania plebańskie oraz opis posiadłości, role i ogrody i łąki. Inwentarz gospodarski. Zapis 1500 florenów poczyniony przez proboszcza Michała Połęszka (sic), k. k. 66v-69.

Wykaz wsi płacących dziesięciny, k. 69-69v.

Wsie parafialne: Osie, Miedzno, Brzeziny, Wierzchy oraz jedenaście miejscowości zwanych pustkowiami, a mianowicie Pruskie, Zgorzały Most, Wymysłowi, Skrzyńczyska, Wygoda, Tlen, Starorzeka, Sobina, Oski Piec, Żur i Dombrowa, k. $69 \mathrm{v}$.

Porządek nabożeństw, k. 69v-70.

Organista Tomasz Kuczkowski, rektor kościoła Wojciech Prabucki, od 1750 r., k. 70 .

Dekret reformacyjny wystawiony w Osiach, dnia 13 III, k. 70-71.

D r z y c i m. Wieś w starostwie świeckim, obecnie w dożywociu księcia Antoniego Jabłonowskiego, wojewody poznańskiego. Była tam świątynia drewniana, na planie krzyża, stara i chyląca się ku ruinie. Poprzedni Proboszcz przewidując, że niedługo ona się zniszczy, wystawił nową z pruskiego muru, którą ukończył i należycie przyozdobił obecny rządca kościoła. Kościół pod wezwaniem Wszystkich Świętych i Oczyszczenia Najświętszej Marii Panny. Konsekracji do- 
konał w 1640 r. biskup [Jan] Małachowski. Prawo patronatu należało do króla. Opis przechowywania Najświętszego Sakramentu, chrzcielnicy i olejów. Wykaz znajdujących się w kościele relikwii. Odpust przypisany do bractwa pięciu ran Pana Jezusa oraz do drugiego bractwa Pocieszenia matki Bożej. Bractwa te nie posiadały osobnego uposażenia. Za łaskami słynące lud uważał wizerunek Ukrzyżowanego znajdujący się pośrodku świątyni i obraz Matki Boskiej Częstochowskiej z głównego ołtarza, k. 71-72.

Opis ośmiu ołtarzy i ich wezwań. Stan wewnętrzny i zewnętrzny świątyni i jej wyposażenia, k. $72-73 \mathrm{v}$.

Wykaz argentariów i pozostałych paramentów liturgicznych, k. 73v-76.

Zabudowania plebańskie. Przytułek z drewna, ostatnio, przez obecnego proboszcza zbudowany, bez własnego funduszu. Miał w nim swoje mieszkanie organista i wikariusz. Ogrody i role dokładnie opisane. Pewna ich część była przeznaczona dla organisty. Wykaz inwentarza gospodarskiego, żywego i martwego. Były też pewne zapisy, k. 76-78v.

Wykaz wsi oddających dziesięcinę: Drzycim, Gacki, Lniano, Witwie, Sierosław, Gródek, Sierosławem, Lnianko, Pólko folwark, Ryszka, Grzybek, Mursz, Dombrowa, Siewkowo, Jeziorki, Jastrzębie, Brzęczek, Luboclenia, Dulsk, Wyry, Ruwiennica, Zalesie, Brzemiona, Mszano, Lubodziesz, Spławie, Dąbrówka, a ponadto Tuchomie, Nowogródeckie i Hammer należące do starostwa oraz szlacheckie Żuławka, Rówieński Most, które dziesięciny nie oddawały, k. 78v-79.

Wsie parafialne: Drzycim starościński, Gacki, Sierosław, Lniano, Wętpie, Gródek, Hammer, Pólko, Ryszka, k. 79.

Porządek nabożeństw, k. 79.

Organista Józef Synoracki, Wikariusz, którym aktualnie był zakonnik franciszkanin z konwentu bydgoskiego, nieobecny w czasie wizytacji, rektorem zaś Gaspar Józef Boruski, kanonik kruszwicki, od 1765 r., rezydujący w parafii, k. 79v.

Proboszcz miał prawo wyrębu drewna w lasach starościńskich, zaś bartnicy mieli dawać jedenaście funtów wosku. Cechy rzemieślnicze, krawców, szewców, kołodziei i mechanicy mieli swoje ołtarze i troszczyli się o światło na nich, k. 79v.

Innowiercy, w liczbie 320 byli we wsiach Zalesie, Lubodziesz, Wyry, Jeziorki, gdzie mieli szkoły, zaś we wsiach Dulsk, Siemkowo, Ponianek i innych, chociaż szkoły nie mieli, ale utrzymywali nauczyciela, który też głosił im kazania, k. 79-80.

Na dworze Siewkowo znajdowała się kaplica prywatna, należycie wyposażona, mająca indult z $1765 \mathrm{r}$. na sprawowanie tam mszy, k. 80 .

Dekret reformacyjny, k. 80-85.

Śli w i c e. Wieś należąca do starostwa świeckiego, w posiadaniu Antoniego Jabłonowskiego, wojewody poznańskiego i starosty świeckiego. Kościół drewniany, wymagający naprawy. Nosi wezwanie św. Katarzyny, konsekrowany, prawa patronatu królewskiego. Opis przechowywania Najświętszego Sakramentu, stan chrzcielnicy i olejów. Relikwie św. Benigny. Wykaz odpustów. Bractwo Bożej Opatrzności, k. 85-86. 
Opis siedmiu ołtarzy, ich wezwań i stanu. Nie było obrazu łaskami słynącego. Stan wewnętrzny i zewnętrzny świątyni i jej wyposażenie, k. 86-87v.

Wykaz argentariów i pozostałych paramentów liturgicznych, k. 87v-88v.

Zabudowania plebańskie, dokładnie opisane, także gospodarcze. Inne zabudowania należące do parafii. Wykaz ogrodów i roli oraz tego, ile się wysiewa tam zboża. Były też pewne zapisy, k. 88v-90.

Dziesięciny pobierano z wsi: Śliwice, Osówek, Lińsk, Śliwiczki, Łążek, Młyn Łoboda, Trzepnicy, Koniny. Były także niektóre kolonie, zwane Pustkowia, które oddawały niewielką opłatę w postaci 2 florenów. Natomiast niżej wyliczone: Laski, Drojna, Linówek, Gajdowskie, jabłonka, Rosochata, Biała, Krowno Wielkie, Krowno Małe, Starzyska, Głuchowo, Woziwoda, Rzewna, Brukniewo, Bielska, Struga, Koniny, Klocek, Koniny Drugie, Krąg, Lubienia, Szlachta, Brzeźno, Zazdrość, Kamionka, Lisiny i Żelcz nic nie płaciły. Podobnie nic nie płaciły proboszczowi wsie Łęski Piec, Zdroje, Osieczko. Jedynym obowiązkiem poza parafialnym proboszcza była msza w piątki w intencji bractwa, za co otrzymywał 16 florenów pruskich, k. 90.

Proboszcz osobiście administrował parafią. Należały zaś do niej następujące wsie: Śliwice, Łążek, Śliwiczki, Ossówek, Lińsk, Trzepnicy, Koniny, Młyn Loboda, Łęski Piec, Zdroje, Szlachta, Rosochata, Krag, Klocek, Koniny Drugie, Laski, Krowna Mała, Krowna Wielka, Biała, Woziwoda, Linówek, Zdrojno, Starzyska, Brzeżno, Rzepna, Brukniewo, Bielska Struga, Zazdrość, Kamionka, Lisiny, Lubocienia, Głuchowo, Gajdowskie, Jabłonka, Jelcz, k. 90-90v.

Porządek nabożeństw, k. 90v.

Inwentarz gospodarski, k. 90v.

Organista Andrzej Kosiecki. Przytułku nie było, ale sześciu ubogich mieszkało we wsi, posługując kościołowi, ale specjalnego funduszu nie było. Proboszcz Jan Łęgowski, od 1742 r., rezydujący na miejscu, k. 90v-91.

Dekret reformacyjny, k. 91-92v.

B y sław. Wieś należąca do starostwa tucholskiego w posiadaniu Jerzego Goltz, starosty tucholskiego. Kościół murowany, konsekrowany, pod wezwaniem Przemienienia Pańskiego. Prawo patronatu należało do króla. Stan przechowywania Najświętszego Sakramentu, chrzcielnicy i olejów. Pacyfikał z relikwiami św. Stefana Męczennika, ale bez dokumentu autentyczności. Przywilej odpustowy za dusze zmarłych i dla bractwa Najświętszego Imienia Jezusowego. Bractwo Najświętszego Imienia Jezusowego zaprowadzone w 1739 r. Bractwo Różańcowe, też w 1739 r, zaprowadzone, posiadające własne uposażenie, k. 92v-93.

Opis pięciu ołtarzy, stanu wewnętrznego i zewnętrznego świątyni i jej wyposażenia, k. $93 \mathrm{v}-94 \mathrm{v}$.

Spis argentariów i pozostałych paramentów liturgicznych, ale dosyć skromnych, wymagających naprawy, k. 94v-95.

Opis zabudowań plebańskich. Opis ogrodów i ról należących do proboszcza. Lasów nie było, ale Proboszcz miał prawo wyrębu drewna na opał i odbudowę zabudowań. Użytkował też staw rybny, położony niedaleko jeziora należącego do 
starosty. Spis inwentarza gospodarskiego żywego i martwego. Były też różne zapisy, k. 95-97.

Dziesięciny pobierano wsi: Bysław, Bysławek, Minikowo, Wełpin, Wierzchlas, Piła Młyn, Ruda, Szumiąca, Huta. Pobierano pewne opłaty, według umowy z wsi Piec Sumiącki i Biełszewo, k. 97-97v.

Wsie parafialne: Bysław, Bysławek, gdzie były zakonnice, Minikowo, Wełpin, Huta, Iwiec, Bieszewo, Wierzchlas, Piec Sumiancki (może Szumiący), Młyn Piła, Ruda Szumiąca, k. 97v.

Porządek nabożeństw, które w niedziele były sprawowane naprzemian z kościołem w Cekcinie. W święta w Cekcynie jedynie w uroczystości się odprawia, w Bysławiu zawsze, k. 97v.

Organista Andrzej Poćwiardowski, rektor zaś Paweł Józef Żmuda Trzebiatowski, k $97 \mathrm{v}$.

Dekret reformacyjny, k. 97v-99v.

C e k c y n. Wieś także w starostwie tucholskim, w posiadaniu dożywotnim Jerzego Goltz, starosty. Kościół drewniany, ostatnio wzmocniony, inkorporowany do Bysławia, pod wezwaniem św. Krzyża, patronatu królewskiego. Opis stanu przechowywania Najświętszego Sakramentu, chrzcielnicy i olejów świętych. Relikwii nie było. Odpust jedynie za dusze zmarłych przywiązany do wielkiego ołtarza. Opis trzech ołtarzy i ich wezwań. Stan wewnętrzny z zewnętrzny świątyni i jej wyposażenie, k. 99v-101.

Wykaz argentariów i pozostałych paramentów kościelnych, k. 101.

Zabudowania plebańskie oraz opis ogrodów i ról oraz łąk i stawu, należących do proboszcza. Był też niewielki zapis 400 florenów, k, 101-102v.

Dziesięciny były z wsi: Cekcyn, Suminy, Zamaże, Zalesie, Młyn Osielsk, Zielonka, Ostrowy, Przygoniła, k. 102v.

Wsie parafialne: Cekcyn, Suminy, Zamarte, kolonie Przygonia, Ostrowy, Gacny, Budziska, Zalesie, Młyn Osielsk, Nowy Młyn, Gacny Wielkie, k. 102v.

Nabożeństwa, raz w Bysławiu, raz w Cekcynie, sprawował rektor tego kościoła, Paweł Józef Zmuda Trzebiatowski, ten sam co w Bysławiu, k. 102v.

Nie ma tu dekretu reformacyjnego, ponieważ był ten sam proboszcz w Bysławiu i Cekcynie.

L u biewo. Wieś należąca do uposażenia arcybiskupa gnieźnieńskiego. Świątynia drewniana, wymagająca naprawy. Nosi wezwanie św. Mikołaja. Konsekrowana, może po odbudowie, w 1611 r. przez bp. Franciszka Łąckiego. Prawo patronatu należało do arcybiskupa. Najświętszy Sakrament przechowywany w tabernakulum należycie urządzonym. Chrzcielnica drewniana, stara, oleje zmieniane każdego roku. Relikwie jedynie te, które są w portatylach ołtarzowych. Odpust na św. Izydora. Bractwo św. Jana Nepomucena. Ołtarzy pięć, tu bliżej nieopisanych. Zakrystia po prawej stronie prezbiterium. Opis wyposażenia wnętrza. Cmentarz ogrodzony, k. 102v-104.

Spis inwentarza i paramentów liturgicznych oraz stan zabudowań plebańskich. Opis uposażenia w ziemię, dokładnie opisaną. Był też dom i ziemia dla 
organisty. Wykaz inwentarza gospodarczego. Proboszcz miał prawo wyrębu drewna na swoje potrzeby w lasach należących do arcybiskupa. Mógł mieć swoje barcie w lasach należących do starostwa Jasieńskiego. Inne informacje zostały podane w tabeli, której w tej księdze nie znaleziono. Wizytacja odbyła się 26 III 1766 r., k. 104-106v.

Dekret reformacyjny, k. 106v-108.

Pr z y s i e r s k. Wizytacja 11 IV 1766 r. Wieś należąca dożywotnio do księcia Jabłonowskiego, wojewody poznańskiego. Świątynia drewniana, ostatnio przez aktualnego proboszcza restaurowana, pod wezwaniem św. Wawrzyńca. Prawo patronatu należało do monarchy. Najświętszy Sakrament przechowywany należycie $\mathrm{w}$ tabernakulum drewnianym, ale należycie przyozdobionym. Chrzcielnica w należytym stanie. Oleje zmieniane każdego roku. Relikwie św. Wawrzyńca i św. Stanisława Kostki, w relikwiarzach. Były przywileje odpustowe. Bractwo Różańcowe założone w 1730 r. i posiadające wlane uposażenie. Pięć ołtarzy, tu opisanych. Opis wnętrza świątyni i jej wyposażenia. Chór z pozytywem. Cmentarz dobrze ogrodzony, k. 108-110.

Nie podano wykazu paramentów liturgicznych, odsyłając do tabeli, której tu nie ma. Opis zabudowań plebańskich, ogrodów i pól, należących do uposażenia. Organista miał tez swoje pola. Wykaz inwentarza gospodarczego, k. 110-112.

Wsie należące do parafii: Przysiersk, Drozdowo, Bukowiec, Budyn, Konopat Polski, Biechówko, Bramka, Gawroniec, Jarzembieniec, Wyrwa, Pniewo, Wiechowo, Konopat Niemiecki, Kawenczyn, Terespole młyn, k. 112-112v.

Wykaz zapisów na parafię. Sposób odprawiania nabożeństw. Rektorem był od 1740 r. Andrzej Józef Hersztowski, posiadający tylko jedno beneficjum, k. 112v$-113$.

Dekret reformacyjny, k. 113-115.

Ł ą k i e. Wizytacja dnia 15 IV 1766 r. Wieś dziedziczna sióstr benedyktynek z Chełmna, w dekanacie świeckim. Kościół drewniany, pozostający w dobrym stanie. W następstwie wojen zniszczeniu uległy dokumenty dotyczące erekcji i uposażenie kościoła, dlatego 13 VIII 1627 r., ksieni konwentu chełmińskiego Magdalena Mortęsta, w swoim i swojego konwentu imieniu wystawiła dokument określający uposażenie, tu dosłownie przytoczony. Został on potwierdzony przez Konsystorz Generalny Włocławski tegoż 1627 r. Świątynia nosi tytuł św. Bartłomieja. Najświętszy Sakrament przechowywany należycie. Chrzcielnica w należytym porządku. Oleje odnawiane każdego roku. Nie było osobnych relikwii. Były przywileje odpustowe. Bractwo Pomocy zmarłym, nieposiadające własnej fundacji, zaprowadzone w 1733 r. za zgodą Konsystorza Foralnego z Bydgoszczy. O1tarzy było trzy, wielki z obrazem Pocieszenia Matki Boskiej, boczny po stronie prawej św. Bartłomieja i po stronie lewej św. Sebastiana. Zakrystia drewniana. Opis wyposażenia świątyni. Na chórze pozytyw. Dzwonnica na cmentarzu nowa, ale jeszcze nie całkiem ukończona i dwa dzwony. Na kościele wieżyczka, jako sygnaturka, k. 115-117. 
Nie ma spisu paramentów liturgicznych, ponieważ odesłano do ich wykazów, na tym miejscu niezamieszczonych. Opis stanu zabudowań kościelnych oraz gruntów, z dosyć dokładnym ich opisem. Inwentarz gospodarczy, k. 117-118v.

Wsie parafialne, oddające też meszne i dziesięcinę: Łąkie, Staszki, Korytowo, Różanna Branica, Więckowom, Głuszyce. Organista Wawrzyniec Jaszkowski, Rektorem, czyli proboszczem, był Jan Humowski, od 1742 r., k. 118v.

Dekret reformacyjny, k. 119-120.

$\mathrm{N}$ i e w i e ś c i n. Wizytacja odbyła się 18 IV 1766 r. Wieś dziedziczna Ludwiki z Czapskich Dworzańskiej. Świątynia drewniana, w dosyć dobrym stanie, ale wieża, z nią złączona, jest zniszczona i zagraża bezpieczeństwu. Dokumenty kościoła zostały albo zniszczone, albo zabrane podczas wojen szwedzkich. Uważa się, że obecna świątynia w 1606 r. została erygowana, czyli pewnie poświęcona przez biskupa Piotra Tylickiego, a zbudowana z fundacji Samuela Konarskiego. Czy było przewidziane należyte uposażenie dla kapłana i sług kościelnych, nie wiadomo. Później, jak to wynikałoby z zachowanych we Włocławskim Archiwum kapitulnym, dziedzice miejscowi według swego uznania zatrudniali kapelanów. 10 XII 1745 r. dziedziczka Ludwika z Czapskich Niewieścińska, właścicielka dóbr Niewieścin i Zembowo, zwróciła, czy też od siebie nadała odpowiednie uposażenie i prosiła biskupa włocławskiego Czapskiego, żeby przysłał komisarzy, którymi byli Wawrzyniec Behme, dziekan i proboszcz ze Swiecia i Wojciech Woldański, proboszcz z Gruczna, w celu zbadania, czy uposażenie w ziemię jest wystarczające. Kościół ten jest pod wezwaniem Trójcy Swiętej, patronatu miejscowych dziedziców. Opis wnętrza świątyni, Najświętszy Sakrament w tabernakulum, znajdującym się na wielkim ołtarzu, był odnawiany co miesiąc. Chrzcielnica $\mathrm{z}$ woda chrzcielną, sporządzona $\mathrm{w}$ Wielką Sobotę. Znajdowały się relikwie, umieszczone w relikwiarzach w formie kolumn. Bractwa nie było. Trzy ołtarze. Wielki z obrazem Trójcy Świętej, boczny po prawej stronie, w nawie głównej, nowy, wystawiony przez obecnego proboszcza, z obrazem Matki Bożej i stojący po przeciwnej stronie ołtarz boczny także z obrazem Maryi. Zakrystia po prawej stronie prezbiterium znajdowała się już praktycznie w ruinie. Dalszy opis wnętrza świątyni i jej wyposażenia. Spis paramentów kościelnych spisano osobno, ale tu go niezamieszczona, k. 120-122.

Opis zabudowań plebańskich i gruntów do proboszcza należących. Były także pewne zapisy sum na procent, k. 122-124.

Wsie należące do kościoła tego : Niewieścin i Zębowo, Soponino, Kozielec, Cieleszynek, Zbrachlin, Wałdowo, Pruszcz, Mruczy, Soponinek. Nabożeństwa sprawowano tak, jak w innych parafiach. Rektorem kościoła był Tomasz Mikołaj Chmielewski, od 1750 r. Wikariusza nie posiadał, k.124-124v.

Dekret reformacyjny, k. 124v-125v.

To p o 1 n o. Wieś szlachecka (nie podano kto był dziedzicem), ze świątynią murowaną. Prawom patronatu należało do dziedziców. Najświętszy Sakrament przechowywany w tabernakulum i odnawiany co dwa tygodnie. Chrzcielnica w należytym porządku z woda chrzcielną. Ołtarz wielkie, jak i boczne, w stanie 
dobrym. Obraz Matki Boskiej w ołtarzu głównym uchodził za łaskami słynący. Dalszy opis stany Kocioła. Jak wynika z dokumentów parafii Gruczno, był ten kościół dawniej filialnym tej parafii. Teraz jest inkorporowany zakonnikom paulinom, którzy mają tu swój konwent, wystawiony jako murowany, gdzie mieszka około dwudziestu zakonników. Przeor konwentu, jest naznaczany przez władze zakonne, i kanonicznie zatwierdzany przez ordynariusza miejscowego, jest jednocześnie proboszczem. Opis uposażenia. W tej parafii było niewielu innowierców, którzy korzystali z sakramentów chrztu i małżeństw w parafii, ale posiadali własny cmentarz, k. $125 \mathrm{v}-126$.

Dekret reformacyjny, k. 127-128.

Piętnaście dalszych kart, posiadających własną foliację od 1 do 15 , jest pustych.

\section{G63a}

\section{A. OPIS KSIĘGI}

[1. Sygn. akt.] G63 a.

[2. Tytuł oryg.] Visitatio Generalis decanatuum Pucensis, Leoburgensis, Mirachowiensis et Bütthoviensis, in dioecesis Pomerana consistentium, sub felici regomine Illustrissimi Excewllentissimi et Reverendissimi Domini Antonii Casimiri de Ostrow Ostrowski, Dei et Apostolicae Sedis gratia episcopi Vladislaviensis et Pomeraniae. Officialatu vero Illustrussimi et Reverendissimi Domini Cypriani Casimiri de Komorze Wolicki, episcopi Sinopensis, praepositi ecclesiae cathedralis nVladislaviensis, suffraganei Pomeraniae, vicarii in spiritualibus generalis ac parochi Gedanensis, per me, Basilium Złocki, archidiacomum Pomeraniae, praepositum Skarszeviensem, visitatorem generalem, expedita anno a Salutifera Nativitate Domini Nostri Jesu Christi $1766-^{\text {to }}$.

[Daty krańc.] 1766.

[Opis zewn.] Łac. $2^{0}(34,0 \times 20,5 \mathrm{~cm})$. Karta niepaginowana 1, stron paginowanych 256. Oprawa dawna, nieco zniszczona. Pismo staranne i czytelne. Sa ślady zabrudzenia. Karty poszczególnych składek są luźne i należałoby księgę ponownie zszyć i oprawić.

Strony puste: 85-96.

[Uwagi] Wizytacja przeprowadzana bardzo dokładnie. Księga zapewne spisana później, bo pismo bardzo staranne i jednej ręki. Ponadto nie zgadza się chronologia, bo często data kolejnej wizytacji w księdze, jest wcześniejsza od poprzednich.

Jest dużo wiadomości do biogramów kapłanów tych dekanatów.

Podawano przy każdej parafii jej przynależność administracyjną i położenie, określając w milach odległości od sąsiednich parafii i większych miast.

Nie we wszystkich protokółach zapisywano wszystko. Często jest inna kolejność. Nie było jakiegoś specjalnie określonego formularza, stąd niekiedy kolejność zapisów w poszczególnych parafiach jest inna. 
Można się dobrze zorientować, jakie wsie należały do poszczególnych parafii i jakie powinności oddawały proboszczom. Nie zawsze jednak można mieć pewność, że to wszystkie są parafialne, bo pewnie nieraz jakieś powinności ponosili mieszkańcy wsi spoza parafii.

\section{B. ZAWARTOŚĆ KSIĘGI}

Wstępne zestawienie stanu dekanatu puckiego (preliminaria), s. I

Kościołów parafialnych - 8;

Kościołów filialnych -6 ;

Kaplic - 2;

Oratoria czyli kaplice prywatne -2 ;

Klasztorów męskich - Wejherowo - 1;

Klasztorów żeńskich - Żarnowiec - 1;

Katolików - 7.174;

Zborów protestanckich -1 ;

Akatolików - 3.050;

Żydów - 74;

Kościół w Żarnowcu będzie wizytowany przez samego ordynariusza.

\section{Wstępne zestawienie stanu dekanatu lęborskiego, s. I}

Kościół prepozyturalny w Lęborku - 1;

Kościoły afiliowane - 6;

Kaplice i oratoria prywatne -

Klasztory -

Katolików - 850;

Zborów protestanckich -17 ;

Akatolików bardzo dużo, ale nie podano liczby;

Żydzi - nie podano liczby.

\section{Wstępne zestawienie stanu dekanatu mirachowskiego, s. II}

Kościoły parafialne - 9;

Kościoły filialne -2 ;

Kaplice - 1;

Oratoria prywatne -1 ;

Klasztor męski kartuzów - 1;

Klasztory żeńskie -

Katolików - 8.413;

Zborów protestanckich -2 ;

Akatolików - 2.048;

Żydzi - 


\section{Wstępne zestawienie stanu dekanatu bytowskiego, s. II}

Kościoły parafialne -6

Kościoły filialne -7

Kaplice - 1

Oratoria prywatne -1

Klasztory -

Katolików - 5.751

Zborów protestanckich -2

Akatolików - 9.225

Żydzi -48

\section{Wizytacja generalna dekanatu puckiego przeprowadzona w $1766 \mathrm{r}$.}

P u c k. Stan kościoła przepozyturalnego w Pucku, podczas wizytacji generalnej, przeprowadzonej 3 II 1766 r. Miasto (civitas) królewskie. Określenie jego położenie w stosunku do najważniejszych miast w diecezji. Kościół murowany, z czasów krzyżackich, pod wezwaniem Apostołów Piotra i Pawła. Prawo patronatu należało do króla. Ołtarz wielki pod wezwaniem św. Trójcy, z nastawą drewnianą, złocona i malowaną. Śwatło przed Najświętszym Sakramentem pali się w dzień i noc. Oleje święte należycie przechowywane w szafce po stronie ewangelii. Znajdowały się relikwie św. Germana. Opis dosyć szczegółowy pięciu ołtarzy bocznych, z których dwa znajdowały się w kaplicacjh. Jeden znajdował się w kaplicy, zwanej Judyckich, przy wielkim ołtarzy, po stronie lekcji, drugi zaś w kaplicy zwanej wejherowską. Na obydwie kaplice były specjalne fundusze zapisane przez fundatorów i były w nich sprawowane specjalne msze przez prebendarzy przy nich zatrudnionych. Zakrystia murowana, s. 1-4.

Dokładny spis inwentarza kościelnego, a więc naczyń srebrnych liturgicznych, szat liturgicznych itp. Ponieważ były dosyć liczne zapisy na msze fundowane, Znajdowały się specjalne tablice wyliczające kiedy i za kogo $\mathrm{V}$ być odprawiane, a także o odmawianym tu oficjum divinum. Spis innych sprzętów, jak dwóch konfesjonałów i ławek. Były spisywane metryki. Opis stanu zewnętrznego świątyni. Wieżyczka nad prezbiterium z jednym dzwonem i dzwonnica osobna murowana, z czterema dzwonami i piątym, który wybijał godziny zegara. Cmentarz dla katolików przy kościele, zaś akatolicy luteranie posiadali osobny, za murami miasta, przy bramie gdańskiej, gdzie dawniej znajdowała się kościół parafialny pod wezwaniem św. Jerzego. Wyznawcy natomiast kalwinizmu mieli cmentarz przy bramie młynarzy. Kostnica murowana. Uposażenie kościoła było jedynie ze zbieranej kolekty oraz z czynszów za domy będące własnością parafii, z racji pogrzebów i zz niewielkiego dochodu od zapisanej sumy, co było zapisane w księdze kościelnej, s. 4-7.

Wsie parafialne:Kruszwica, Rucewo, Ostonino, Beka, Mrzeżyno, Połchowo, Smolno, Żelistowo, Błędnikowo, Celbowo Małe, Słautowie Wielkie, Słautowie 
Małe, Brudzewo, Połczyno z pustkowiem zwanym Kompin. Spowiadających się na Wielkanoc było 1652 osoby. Nie wiadomo było, kiedy odbywały się ostatnie misje, s. 7.

Dom proboszcza z pruskiego muru, stary. Podobnie w złym stanie były domy dla wikariuszów, prebendarzy i kaznodziei. Nie było bractwa, ale nie było też jego promotora, ani mieszkania dla niego. Organista i kantor mieszkali w domu zwanym kantoria. Szkola w pobliżu kościoła. Zakrystianin z kantorem śpiewali oficjum, dlatego też mieli mieszkanie. Inne zabudowania plebańskie oraz wykaz ogrodów, pól i lasu, należącego do parafii. Spis inwentarza gospodarskiego. Ze zwyczaju, do odbudowania zabudowań plebańskich byli zobowiązani mieszczenie tego królewskiego miasta, $\mathrm{z}$ pomocą innych parafian, co potwierdził w wizytacji generalnej z 1702 r. Krzysztof ze Słupów Szembek, s. 7-9.

Dokładny wykaz wsi oddających meszne z podaniem jego wysokości, s. 9-10.

W ostatnim roku ochrzczono 92 dzieci, ślubów było 9, zaś pogrzebów 43. Ogółem parafia liczyła 821 mężczyzn, 831 kobiet, chłopców 364, a dziewcząt 452. Nie było na terenie parafii klasztorów, zborów innowierczych, czy kaplic prywatnych. Luteran mężczyzn było 84, zaś kobiet 69 osób. Byli kalwiniści w liczbie 3 mężczyzn i 4 kobiety, s. 10.

Rektor kościoła Franciszek Adam Goldman, lat 53, w parafii od 1765. W parafii rezyduje. Wikariusze: Jan Józef Netzell, Polak i Karol Walenty Rasszkie, Niemiec, którzy V kazania odpowiednia dla Niemców i Polaków. Bractwa nie było, stąd nie było też zjego promotora. Organista Jan Michał Cenker, kantor Antoni Wojciech Wolszczon. Nauczycielem był organista, zaś kantor pełnił obowiązki zakrystianina. Witrykusi, czyli prowizorzy z miasta: Jerzy Cygiel,Wawrzyniec Meszkie, Jan Busz, Tomasz Doryng, Jan Krzysztof Szembek. Ze wsi natomiast nimi byli: Maciej Choyka, Tomasz Halman, Jan Kloc. Prowizorami szpitala byli: Antoni Zygiel i Michał Halman, mieszczanie z Pucka. Uczniów około 20. Akuszerki zaprzysiężone w każdej wsi, s. 10-11.

Szpital, wystawiony na sposób pruskiego muru, dwukondygnacyjny, przy bramie gdańskiej, na ziemi liczącej cztery łany, kryty dachówką. Dawniej był przy nim kościół św. Jerzego, parafialny, ale został zniszczony podczas wojen szwedzkich. Aktualnie było 10 podopiecznych, prowadzących wspólne życie. Rachunki z ofiar dla nich prowadza prowizorzy. Nie było aktualnie kościoła szpitalnego i kapelana, s. 11.

Dekret reformacyjny wystawiony 3 II 1766 r. w Pucku, s. 11-12.

Wej h e row o. Stan kościoła prepozyturalnego wejherowskiego i filialnego w Górze stwierdzony podczas wizytacji z dnia 6 II 1766 r. Miasto (oppidum) szlacheckie Urszuli Przebendowskiej, wojewodziny malborskiej. Określenie jego położenie w stosunku do najważniejszych miast diecezji. Kościół dawny, zniszczony, został odbudowany, jako murowany, w latach 1654-5 przez nieżyjącego już Piotra Jerzego Przebendowskiego, wojewodę malborskiego, starostę mirachowskiego i puckiego. Jest pod wezwaniem Świętej Trójcy. Prawo patronatu należało do Urszuli z Potockich Przebendowskiej i jej syna, Ignacego Przebendowskiego, starosty mirachowskiego i puckiego, s. 13. 
W ołtarzu głównym, marmuru, po wezwaniem Trójcy świętej, znajdowało się tabernakulum drewniane, złocone i malowane zewnątrz. Na to, aby ciagle paliło się światło przed Najświętszym Sakramentem, brakowało ofiar. Oleje przechowywane w szafce znajdującej się w murze, dobrze zamkniętej. Relikwii nie było. Kilka przywilejów odpustowych, tu wymienionych. Ołtarze boczne dwa. Po stronie ewangelii pod wezwaniem Matki Boskiej, po przeciwnej św. Anny, s. 13-14.

Dokładny spis paramentów liturgicznych, naczyń srebrnych i innych, szat liturgicznych. Wykaz ksiagg liturgicznych, także tych w języku niemieckim. Organy nowe. Sprzęty kościelne, szafy na paramenty liturgiczne. Chrzcielnica stara, ale dobra. Oleje w naczyniach dobrze oznaczonych, s. 14-17.

Opis ołtarzy: wielkiego pod wezwaniem Świętej Trójcy, jeszcze niekonsekrowanego, wykonanego z marmuru. Ołtarz boczny pod wezwaniem Matki Boskiej Szkaplerznej i ołtarz trzeci pod wezwaniem św. Anny. Bractwo szkaplerza św., zaprowadzone przez karmelitów w 1741 r., ale nie posiadające własnego uposażenia, ale mające własne paramenty liturgiczne, tu wymienione, s. 17.

Porządek nabożeństw oraz wykaz zobowiązań, płynących z fundacji, s. 17-18.

Opis stanu wewnętrznego i zewnętrznego świątyni, s. 18.

Wsie parafialne: Nanie, Smiechowo, Pentkowice, karczma poza miastem, karczma pod lasem oraz osada młyńska. Spowiadających się na Wielkanoc w tym roku było: Z Wejherowa 377; ze wsi Nanie 33, ze Smiechowa 108, z Pentkowic 38. Ogółem liczba spowiadających się, w tym też spośród szlachty i przybyszów a Pomorza, był 920 osób, s. 18-19.

Dom rektora, poprzedni z 1459 r., z pruskiego muru, został ostatnio odbudowany. Opis pozostałych zabudowań plebańskich, uposażenia i odbieranych dziesięcin oraz innych dochodów. Spis inwentarza gospodarczego, s. 19-20.

W parafii był klasztor franciszkanów reformat o z wieloma kaplicami na tzw. Kalwarii. Nie było kaplic prywatnych. Zbór protestancki we wsi szlacheckiej Bolszewo, gdzie tamtejszy dziedzic utrzymuje kaznodzieję, bo w tej wsi jest dużo innowierców. Żydów było dorosłych 36, a dzieci 38 osób. W Wejherowie było wielu innowierców, ale ni zostali dopuszczeni do magistratu. Na wsiach parafialnych też dużo luteran, ale ostatnio nawróciło się75 osób. Luteranie chowają się w miejscu sąsiadującym z cmentarzem, s. 20-21.

Rektorem był Goderferdg Makowski, liczący lat 46, w parafii oid 1765. Nie było wikariusza, a w miare potrzeby pomagają zakonnicy. Organista Bonawentura Berendt, rajca miejski, będący jednocześnie Kantorem. Nie było nauczyciele, ale dzieci uczyli zakonnicy, takn iż miał kto usługiwać jako ministrant. Zakrystian Andrzej Jagiellowicz. Wtrykusi: Karol Goldman i Michał Łapin. Akuszerki należycie przygotowane. Szpital, znajdujący się obok cmentarza, został przed kilkoma laty odbudowany z pruskiego muru. Miał on zapisany pewien fundusz, dający roczny dochód na utrzymanie ubogich tu się znajdujących, ale także korzystali oni z jałmużny. Był też do ich dyspozycji ogród, który dzielili pomiędzy siebie. Aktualnie było sześciu podopiecznych, którzy z posługi religijnej korzystali w kościele, ponieważ nie było kościoła szpitalnego, s. 21-22.

Opis stanu kościoła filialnego w G ó r z e. Był to kościół drewniany, znajdujący się stanie dużego zniszczenia. Był pod wezwaniem św. Mateusza Apostoła. 
Prawo patronatu należało do króla, zaś posiadaczem tej wsi był Jakub Przebendowski. Wprawdzie nie było tu stałego proboszcza, to w tabernakulum znajdującym się w wielkim ołtarzu, niepodanego wezwania, przechowywano Najświętszy Sakrament, ale światło paliło się jedynie podczas nabożeństw. Znajdowały się też tu oleje święte, każdego roku odnawiane. Ołtarze boczne miały wezwanie św. Mateusza i Trzech Króli. Zakrystia po stronie ewangelii, s. 23.

Spis inwentarza i paramentów liturgicznych. Księgi liturgiczne, w tym ewangeliarz w języku polskim i niemieckim. Księgi metryk spisywane dobrze, ale znajdowały się u proboszcza. Była też chrzcielnica i piscyna. Nabożeństwa w niedziele i święta, tu wymienione, s. 23-24.

Opis stanu i wyglądu świątyni. Dzwonnica drewniana z trzema dzwonami. Uposażenie stanowiła składka zbierana podczas kazania oraz opłaty przy pogrzebach, s. 24.

Wsie przynależące do tego kościoła: Góra, Żelewo Kniewo, Rybno, Grynkowo z młynem, gdzie mieszkali luteranie, Grabowino, Warszkowo, owczarnia zwana Prześniewicksa, należąca do właściciela z Bolszewa, Bolszewo, gdzie znajdowały się trzy dwory, dwa jednego właściciele Janowica i trzeci wdowy o nazwisku Massau, karczma o niepodanej nazwie, cegielnia wspomnianej właścicielki Massau oraz wieś Orle. Dawne wizytacje wspominały, że w Bolszewie była dawniej świątynia, filialna parafii w Górze, teraz już nieistniejąca, a na jej miejscu stał zbór protestancki. Także we wsi Kniewo dawniej znajdowała się kaplica pod wezwaniem św. Marii Magdaleny, wzniesiona przez mieszkańców jako wotum za ocalenie od zalania woda, czyli od powodzi. Spowiadających się w ostatnim roku było: z Góry 61, Bolszewa 42, Żelewa 58, Rybna 38, Warszkowa 29, Kniewa 8, Orla 11 oraz 116 osób z różnych miejscowości, s. 24-25.

Dom proboszcza bardzo stary i wymagał odbudowania, i było małe pomieszczenie, gdzie zatrzymywał się wikariusz, gdy przybywał tu dla sprawowania nabożeństw. [pewnie któryś z zakonników, bo w Wejherowie wikariusza nie było]. Inne zabudowania gospodarcze wymagały reperacji. Były cztery łany ziemi, położone pomiędzy polami kmiecymi i każda działka miała swoją nazwę, ty wyliczone. Było też prawo wyrębu drewna na opał oraz połowu ryb w jeziorze koło wsi Orle. Wykaz pobieranych dziesięcin w zbożu. Wykaz całego dochodu proboszczowskiego. Inwentarza gospodarczego nie spisano, bo tu proboszcz gospodarstwa nie prowadził. W ostatnim roku było 26 chrztów, 2 śluby i 8 pogrzebów. Parafia liczyła 372 mężczyzn, 302 kobiety, 95 chłopców i 103 dziewczęta. Żydzi mieszkali w Bolszewie i liczyli 36 osób, ale własnej synagogi nie mieli, a swoje nabożeństwa odprawiali w jednym z domów. Opłacali proboszczowi pewną należność z racji kolędy. Posiadali własna szkolę. Luteran było 440 osób zaś kalwinistów 2 osoby, s. 25-26.

Proboszczem był proboszcz z Wejherowa. Organista i zakrystian w jednej osobie, Kazimierz Zelk, witrykusi Jan Preiss i Emanuel Półtorak. Akuszerka z Góry, wystarczająco pouczona. Szpitala nie było, s. 26-27.

Dekret reformacyjny dla parafii Wejherowo i Góra, wystawiony w Wejherowie 6 II $1766 \mathrm{r}$. 
M e c how a. Stan kościoła parafialnego w Mechowej i filialnego w Starzynie, podczas wizytacji przeprowadzonej 4 II 1766 r., opisany tego dnia w Mechowej. Wieś ta należała do opactwa oliwskiego. Określenie położenia parafii. Świątynia zbudowana z muru pruskiego w 1742 r. przez opata z Oliwy Jacka Rybińskiego, pod wezwaniem św. Jakuba i Mikołaja. Prawo patronatu należało do opata z Oliwy. Ołtarz wielki pod wezwaniem Ukoronowania Najświętszej Panny Marii, $\mathrm{z}$ tabernakulum i jednym obrazem w dolnej, a drugim w górnej kondygnacji. Przy chrzcielnicy, w specjalnej szafce przechowywano Oleje święte, zmieniane każdego roku i brane z Konsystorza Gdańskiego. Wykaz odpustów. Cztery ołtarze boczne. Jeden naprzeciwko zakrystii, pod wezwaniem św. Jakuba, z jego obrazem. Dwa ołtarze znajdujące się na wysokości miejsca udzielania Komunii wiernym, a z nich jeden, po stronie prawej pod wezwaniem Matki Boskiej Różańcowej, a wyżej był wizerunek św. Józefa. Po stronie przeciwnej ołtarz mający w dolnej kondygnacji obraz św. Jana Nepomucena, w górnej zaś św. Judy Tadeusza. Czwarty zaś znajdował się naprzeciwko wejścia do świątyni, mający w dolnej kondygnacji obrazyśw. Jakubai Mikołaja, w górnejwyobrażenieBoga Ojca w chmurach. Nie było obrazu łaskami słynącego. Spis obrazów noszonych w procesji. Zakrystia po lewej stronie i opis sprzętów niej się znajdujących, s. 28-29.

Spis paramentów liturgicznych, naczyń srebrnych i z mosiądzu, krzyży i kandelabrów oraz szat liturgicznych, s. 29-30.

Nie było specjalnych zobowiązań, co do mszy w określonych intencjach. Porządek nabożeństw tak, jak to było od dawnego czasu. Opis wnętrza świątyni i jej wyposażenia. Drewniana wieżyczka nad wielkim ołtarzem, ale bez sygnaturki. W dzwonnicy nowej, z pruskiego muru, dwa dzwony. Cmentarz ogrodzony. Kostnice, z muru pruskiego, przylegała do świątyni, s. 30-31.

Wsie parafialne: Mechowa, Darzlub, Leśniewo, Polchowo, Domanowo, Piaśnica Wielka, Piaśnica Mała. Niektóre wioski liczyły jedynie po kilka domów. Były też dwa nałe folwarczki w lesie, ale one nic nie dawały proboszczowi. Wiernych spowiadających się na Wielkanoc było 445 osób, s. 31 .

Dom proboszcza z pruskiego muru, ale pod strzechą. W tym samym domu było mieszkanie dla wikariusza. Obowiązki kaznodziei spełniał sam proboszcz. Nie było żadnego prebendariusza, ani promotora, bo też nie było bractwa. Tylko przy kościele filialnym było bractwo św. Józefa, którego promotorem był wikariusz. Mieszkanie dla organisty, który pełnił też obowiązki kantora, zakrystiana inauczyciela, było naprzeciwko kościoła, wystawione przed dwoma laty przez aktualnego proboszcza. Stan i9nnych zabudowań. Opis uposażenia w grunty, łąki oraz pewne zapisy. Zestawienie dochodów rocznych parafii, s. 31-33.

$\mathrm{W}$ ostatnim roku były 23 chrzty, 2 śluby, 6 pogrzebów. Ogółem było w parafii 232 mężczyzn, 219 kobiet, chłopców - 93 i dziewcząt - 98 osób. Luteranie byli w liczbie 32 osób, zaś kalwinistów było 18, s. 33 .

Rektorem kościoła był zakonnik cysters Dionizy Grossmann, urodzony w 1722 r., rezydujący zawsze w parafii. Miał on wszystkie potrzebne księgi liturgiczne. Wikariuszem był tez zakonnik cysterski, Wojciech Poschman. Organista był Marcin Chyncka, żonaty, który uczył tak chłopców, jak i dziewczęta. Pobierał wynagrodzenie od parafian, tu dokładnie opisane. Był on, jak to wyżej zaznaczo- 
no, także kantorem, zakrystianem i nauczycielem. Witrykusi zaprzysiężeni: Maciej Bolda, sołtys z Mechowej, Jan Kunca i Jerzy Reissman. Uczniów było około 10. Akuszerki należycie pouczone. Szpitala nie było, ani funduszu dla niego, s. 33-34.

Stan kościoła filialnego w S t a r z y n i e. Wies ta także należała do opata oliwskiego. Stojący to kościół murowany, pod wezwaniem świętego Michała Archanioła, został wystawiony przez opata Dawida Kensowskiego. Prawo patronatu należało do opata. Ołtarz wielki w obrazie głównym miał wizerunek Ukoronowania matki Bożej, a wyżej wyobrażenie św. Jana Chrzciciela. Z ołtarzy bocznych jeden miał obraz Zmartwychwstania pańskiego, drugi zaś Narodzenia Pana Jezusa. Niebyło obrazusłynącegołaskami. Było bractwośw. Józefa. Wspomniano o obrazach noszonych jako feretrony. Zakrystia murowana, s. 35-36.

Spis paramentów i szat liturgicznych. Bractwo św. Józefa posiadało własne paramenty. Na specjalnej tablicy wypisano obowiązkowe nabożeństwa za ofiarodawcę Franciszka Kłanieckiego, czy dobroczyńców bractwa, s. 36-37.

Opis stanu zewnętrznego świątyni murowanej. Dzwonnica murowana z trzema dzwonami. Kostnica murowana, s. 37-38.

Wsie parafialne: Starzyno, Werblino, dwór Starzyński, Kłanino, Rosiewo, Parskowo oraz dom w lesie zwany Rzemiętowko. Na Wielkanoc spowiadało się 263 osoby. Misje ostatnie były przez 30 laty, s.38.

Dom rektora kościoła drewniany, ale ten mieszkał w Mechowej, podobnie jak i wikariusz czy organista. Był nauczyciel, jednocześnie pełniąc obowiązki zakrystiana. Dla niego, staraniem obecnego rektora wybudowano mieszkanie. Remontami i utrzymaniem szkoły zajmują się sami mieszkańcy. Opis uposażenie parafii, s. 38 .

W ostatnim roku było 19 chrztów, 1 ślub i 6 pogrzebów. Ogółem mężczyzn naliczono 231, kobiet 232, chłopców 98, a dziewcząt 64. Kaplica prywatna we dworze w Starzynie. Przy tym kościele filialnym były własne księgi liturgiczne. Wikariusz Wojciech Poschanan, nauczyciel szkoły Jerzy Głowienka, wynagradzany przez parafię i to utrzymanie zostało tu podane. Witrykusami byłi Jan Białk, sołtys starzyński, Andrzej Dettlaff, Marcin Langa i Jerzy Bratk. Uczniów było 12. Dwie akuszerki, wdowa Anna Smerlongowa i żona Macieja Nadolskiego, s. 39.

Dekret reformacyjny wystawiony w Mechowej dnia 4 II 1766 r., s. 39-40.

O k s y w i e. Stan kościoła parafialnego w Oksywiu i filialnego w Chylonii, podczas wizytacji przeprowadzonej 1 II 1766 r. Wieś należała do zakonnic norbertanek z Żukowa. Kościół parafialny, po0łożzony na wzniesieniu w pobliżu morza Bałtyckiego, prawa patronatu sióstr norbertanek, noszący wezwanie św. Michała Archanioła, murowany. Ołtarz wielki pod wezwaniem św. Michała Archanioła, ołtarz boczny z prawej strony Wniebowzięcia Najświętszej Marii Panny, z lewej św. Barbary. Zakrystia no stronie prawej, murowana. Opis wyposażenie świątyni w potrzebne meble, ławki, ambona, konfesjonał, chór $\mathrm{z}$ małym organem. Dzwonnica drewniana, sygnaturka mała pośrodku kościoła, Kostnica z pruskiego muru, ogrodzenie cmentarza drewniane, ale dobre, s.41-42. 
Nie było dokumentu erekcyjnego, ale znajdował się przywilej wystawiony w Gdańsku w 1457 przez biskupa włocławskiego, którym był wówczas Jan Gruszczyński. Dokument, tu dosłownie przytoczony, mówił o kręgu parafii w Oksywiu oraz o afiliacji kościoła w Chylonii do tej parafii. Do parafii w myśl tego dokumentu należały wsie: Obłuża, Pogoże, Niemietowo, Kassakowo, Dębogórze, Pierwoszyno, Piaski, Redłowo, Wittomino, Gdynia, Farsrtrna, s. 41-43.

Nie było stałego uposażenia kościoła, jedynie ofiary zbierane przez prowizorów i połowa opłat za pogrzeby. Wykaz wyposażenie w paramenty, szaty i księgi liturgiczne. Było kilka przywilejów odpustowych. Kaplica prywatna w dobrach opackich Mosty była murowana, a w Witominie, dla wygody zakonników św. Brygidy z Gdańska, także znajdowała się kaplica, s. 43-44.

Proboszcz, czyli rektor, Łukasz Jan Krzykowski, pochodzący z diecezji pomorskiej, dziekan gdański, spowiednik zakonnic w Żukowie, od 1756 r. Wikariusz Antoni Lofanczyk. Prowizorami byli: Michał Fichta, sołtys z Obłużyna, Andrzej Kruza i Wojciech Górski, mieszkańcy oksywscy. Organista Mikołaj Borys, który także uczył dzieci. Miał uposażenie, tu opisane, s. 44-45.

Dom proboszcza z pruskiego muru. Opis innych zabudowań plebańskich i uposażenia. Spis inwentarza gospodarczego, żywego i martwego. Spis pobieranej dziesięciny, sporządzony wioskami. Niektóre wioski nie oddawały nic, s. 45-46.

W parafii w roku 1765 było ogółem mężczyzn katolików 605, a luteran 14; kobiet katoliczek 560, a luteranek 9; chłopców katolickich 229, dziewcząt luterańskich 2, dziewcząt katoliczek 193, a luteranek 6. Innowiercy nie mieli tu swojego zboru. Było 6 akuszerek wystarczając o przygotowanych, s. 46-47.

Bractwo św. Barbary, którego dokument erekcji, wystawiony przez papieża Benedykta XIV z 1763 r., tu został przytoczony w całości. Bractwo to posiadało własne paramenta liturgiczne, s. 47-49.

Stan kościoła filialnego w $\mathrm{C}$ h y 1 o $\mathrm{n}$ i i. Wieś królewska, aktualnie w posiadaniu Przebendowskiego, chorążego pomorskiego. Znajdował się w niej kościół filialny parafii Oksywie. Jak to wynikało z przytoczonego wyżej dokumentu biskupa Jana Gruszczyńskiego, kościół w Chylonii był przez niego w 1457 r. odnowiony, a więc była to aktualnie światynia bardzo stara. Prezbiterium miała murowane, zaś nawę częściowo murowaną, częściowo z pruskiego muru. Nosiła wezwanie św. Mikołaja. Ołtarz wielki nosił wezwanie patrona, zaś boczne św. Jana Nepomucena i św. Walentego. Opis świątyni i jej wyposażenia w meble. Chór z małym organem. Zakrystia murowana po prawej stronie. Chrzcielnica. Metryki chrztu spisywano. Dzwonnica drewniana $\mathrm{z}$ dwoma dzwonami. Dawne wyposażenie w naczynia liturgiczne, a także księgi, przechowywane u jednego z witrykusów, spaliły się pożarze. Sprawiono nowe, tu wyliczone, jak również pozostałe paramenty liturgiczne. Niedaleko od wsi Chylonia, przy drodze wiodącej do Gdańska, na wzgórzu w lesię, stała kaplica św. Mikołaja, zbudowana z pruskiego muru. Rektorem był Łukasz Jan Krzykowski, proboszcz z Oksywia. W zabudowaniu proboszczowskim zamieszkiwał jeden z wieśniaków, s. 49-51.

Dekret reformacyjny, wystawiony w Oksywiu, dnia 1 II 1766 r., s. 51. 
R u m i a. Wieś z kościołem pod wezwaniem Świętego Krzyża, którego prezbiterium było murowane, ściana frontowa i nawa z pruskiego muru, prawa patronatu kościelnego - opata z Oliwy. Opis stanu zewnętrznego świątyni. Wieża z pruskiego muru, z trzema dzwonami. Ostnica murowana. Ołtarz główny nosił wezwanie Świętego Krzyża, boczne Opatrzności Bożej i św. Józefa. Tabernakulum, dobrze utrzymane i zamykane, na wielkim ołtarzu, a odnawianie świętych postaci odbywało się dwa razy w miesiącu. Były przywileje odpustowe, w tym dla bractwa Bożej Opatrzności dane na stałe. Bractwo to zaprowadzono w 1730 r., a jego promotorem został proboszcz. Zakrystia murowana po prawej stronie, s. 52-53.

Inwentarz paramentów liturgicznych, naczyń srebrnych i innych oraz szat, s. 53-54.

Do tego kościoła należała wieś Rumia i Kazimiria. W 1765 r. 189 osób. Chrztów było 35, ślubów 3, pogrzebów 8. Mężczyzn naliczono 97 kobiet 85, chłopców 32 i dziewcząt 36 . Ponadto było luteran mężczyzn 4, kobiet zaś 2 osoby, s. 54.

Proboszczem od 1757 r. był zakonnik z Oliwy, Mikołaj z Lerchenfeldt, liczący lat 38. Wikariusz Kajetan Szemierowski, także zakonnik cysters. Opis uposażenie proboszcza, na co składała się ziemia oraz dziesięciny. Opis zabudowań plebańskich. W starej plebanii mieszkali ubodzy. Był organista uczący dzieci, wynagradzany przez parafian. Byli prowizorzy, nie wymienieni z nazwiska oraz akuszerki, s. 54-55.

Inwentarz gospodarczy, żywy i martwy, s. 55.

Stan kościoła w R e d z i e. W tej wsi był kościół filialny parafii Rumia, dawniej parafialny, pod wezwaniem św. Katarzyny. Była to świątynia drewniana, ale z powodu zacieków chyląca się ku ruinie, która powinna zostać z pomocą Bożą odbudowana od nowa jako murowana. Dzwonnica drewniana z trzema dzwonami. Prawo patronatu należało do króla polskiego. Ołtarz wielki pod wezwaniem św. Katarzyny, z tabernakulum. Ołtarze boczne nosiły wezwania Świętej Trójcy i Najświętszej Marii Panny. Przywileje odpustowe na święto Wniebowstapienia Pańskiego i na św. Katarzynę. Bractwo Różańcowe zaprowadzone w 1743 r. Dochód kościoła pochodził ze składanych ofiar i z pogrzebów. Akuszerki były dobrze przygotowane. W 1765 r. było 11 chrztów, 2 śluby i pogrzebów 7 . Na Wielkanoc spowiadało się 326 mężczyzn, 319 kobiet, ponadto było w parafii 43 chłopców i 54 dziewczęta. Luteran mężczyzn było 66, a kobiet 39 oraz 2 kalwinistów. Za czasów obecnego proboszcza nawróciły się z luteranizmu 24osoby, s. 55-56.

Inwentarz paramentów liturgicznych, ksiag tak liturgicznych, jak i metryk, s. 57.

Uposażenie proboszcza w ziemie i dziesięciny, dokładnie z poszczególnych wsi wyliczone. Były to wsie: Reda, Ciechocino, Rekowo, Zagorz, Pieleszewo, Gniewowo, Łużyce, Wyspowo, Zbychowi, Pańska Wola i Nowy Dwór, z którego nic nie oddawano. Przy kościele mieszkał nauczyciel uczący dzieci, posiadający dom, ogród i pobierający wynagrodzenia z parafii, s. 57-58.

Dekret reformacyjny, wystawiony w Rumii, dnia 1 II 1766 r. 
T u t o w o. Wizytacja 5 II 1766 r. Wieś dziedziczna Józefa Przebendowskiego, z nowym kościołem z pruskiego muru z niewielka wieżą na środku z dwoma dzwonami, a dzwon duży został przeniesiony do parafialnego kościoła w Luzino przez Macieja Rzepczyńskiego, dziekana mirachowskiego i proboszcza z Luzina, ale obecnie kolator z aktualnym proboszczem chca go odzyskać. Dokument erekcji tego kościoła z 1755 r. znajduje się w aktach ziemskich tczewskich, zaś odpis jest u proboszcza. Świątynia jeszcze nie konsekrowana, pod wezwaniem Matki Boskiej, a jej kolatorem jest dziedzic wsi. W świątyni są trzy ołtarze, z których boczne $\mathrm{V}$ wezwania św. Józefa i św. Jana Nepomucena. W ołtarzu wielkim było tabernakulum. Zakrystia po stronie lekcji, z pruskiego muru, za mała proporcjonalnie do świątyni, s. 59-60.

Wyposażenie w paramenty liturgiczne było wystarczające. Na mocy pierwotnej fundacji dokonanej przez nieżyjącą już wojewodzinę żmudzką Morsztynowi, był obowiązek, żeby proboszcz odprawiał tygodniowo dwie msze z tytułu zapisu i otrzymywał wówczas zapłatę 175 florenów zabezpieczonych na dobrach Tołowo i Lubocino. Zaś z tytułu zapisu Przebendowskiego proboszcz odprawiał jedna mszę za otrzymaną łąkę, a drugą za łąke znajdująca się w lesie. Opis wyposażenia świątyni w potrzebne sprzęty oraz stanu zewnętrznego, który wyglądał dobrze. Na utrzymanie świątyni szły składane ofiary, s. 60.

Do parafii należały wsie Tutowo i Lubocino. Na Wielkanoc spowiadało się 77 osób. Dom proboszczowski z bardzo złym stanie, ale kolator zadeklarował, że wystawi nowy. Nie było potrzeby domu dla wikariusza, prebendarza czy promotora bractwa. Nie było specjalnego domu dla organisty i mieszkał on w maleńkim domku danym przez kolatora. Opis innych zabudowań plebańskich. Uposażenie proboszcza $\mathrm{w}$ ziemię i pewne zapisy oraz meszne $\mathrm{z}$ wyżej wspomnianych wsi, zamiast dziesięciny. Ostatnio były w roku jedynie trzy chrzty, trzy śluby i 4 pogrzeby. Mężczyzn naliczono 35, kobiet 42, chłopców 17 - dziewcząt 21. Nie było żadnych kaplic, klasztorów itp. Na Terenia parafii zamieszkiwało jedynie 4 luteran, s. 60-62.

Rektorem był Piotr Isnarner, liczący lat 46, w parafii od 1763 r. Nie było innych kapłanów, ani organisty, ale kolator zapewnił na przyszłość dla niego wynagrodzenie, stwierdzając, że organista powinien być. Witrykusami byli Jan Hosst i Jakub Janik. Nie było szpitala, akuszerek, czy klasztoru, s. 62-63.

Dekret reformacyjny dla parafii w Tutowie, wystawiony tamże dnia 5 II 1766 r., s. 63 .

S w a r zew o. Wizytacja dnia 3 II 1766 r., obejmująca parafię Swarzewo i kościoły filialne w Strzelnie i Łebczu. Swarzewo było wsią królewską z kościołem pod wezwaniem Narodzenia Najświętszej Marii Panny. Prezbiterium murowane i jak mówi tradycja, zostało zbudowane z ofiar żeglujących po morzu. Nawa główna z pruskiego muru. Opis stanu świątyni. Dzwonnica nowa na cmentarzu $\mathrm{z}$ trzema dzwonami. Cmentarz ogrodzony z kostnica. Dokumentu erekcyjnego nie ma, bo wojny, czy inne zdarzenia go zniszczyły, ale jest zachowany w aktach miejskich Pucka przywilej królewski, wystawiony w Piotrkowie w roku 1648 dla wsi Swarzewo, Grossendorff, Bełcz i Strzelno, zatwierdzający nadanie uposaże- 
nia dla kościoła dokonane jeszcze przez Krzyżaków. Było też w tym dokumencie przypomnienie zobowiązujące parafian z Łebcza do zbudowania kościoła i plebanii, a także przestrzegania dawnych zwyczajów. Nie wiadomo nic o konsekracji tej świątyni. Z wizytacji z czasów, gdy archidiakonem pomorskim był Krzysztof Szembek, późniejszy prymas, można się dowiedzieć, że około 1720 r., kiedy kościół parafialny był zniszczony, proboszcz ówczesny Jan Bogucki wzniósł nowy, ten, który aktualnie istnieje. Jednak omawiana wizytacja stwierdza, że prezbiterium, wraz z zakrystia, pochodzi z tego dawnego kościoła. W kościele było sześć ołtarzy: Ołtarz wielki pod wezwaniem Narodzenia Najświętszej Marii Panny, zbudowany, czy przyozdobiony w 1747 r., boczne zaś w prezbiterium nosiły wezwanie św. Anny i był z fundacji archidiakona pomorskiego Judyckiego, a drugi św. Barbary. W tym ołtarzu od czasów najdawniejszych znajdował się obraz Matki Boskiej laskami słynący. Trzeci ołtarz boczny w prezbiterium, fundowany przez wikariusza Starzewskiego, Jana Makowskiego, nosił wezwanie św. Jana Nepomucena i św. Antoniego Padewskiego, patrona rybaków ze wsi Kusfeldt. W nawie głównej, znajdowały się, po obu stronach, nowe ołtarze noszące wezwanie Przemienienia Pańskiego i Matki Boskiej Szkaplerznej. Chrzcielnica znajdowała się w pobliżu ołtarza Przemienienia Pańskiego. Były przywileje odpustowe. Bractwo Szkaplerza świętego, zaprowadzone w 1718 r. Zakrystia murowana po stronie ewangelii z odpowiednim umeblowaniem, s. 64-67.

Inwentarz paramentów kościelnych, w tym także te, które należały do bractwa. Inne sprzęty kościelne i księgo liturgiczne. Metryki spisywano poprawnie. Na uposażenie kościoła składały się dwa domki wystawione na gruncie kościelnym przez Jana i Andrzeja Ciszkowskich, za zgodą proboszcza Jana Boguckiego, dziesięć pni pszczół z ofiary Jerzego Czappa oraz ofiary składane w kościele, s. 67-70.

Wsie należące do parafii nie oddawały dziesięcin, a jedynie meszne. Były to wsie: Swarzewo, Gnieździewo, Grossendorff. Wsie rybackie na Półwyspie Helskim: Jastarnia Pucka, Kusfeld, Chałupy. Katolików w parafii naliczono 1133, którzy dopełnili obowiązku spowiedzi wielkanocnej. Luteran obojga płci było 184, kalwinistów 18. Nawróciło się za czasów obecnego proboszcza 8 osób. Innych wyznań, ani Żydów nie było. W Jastarni puckiej była nowa kaplica prywatna w Jastarni Puckiej, wystawiona przez wdowę Urszulę Przebendowską, wojewodzinę malborską, za zgoda Konsystorza Gdańskiego, na prośbę proboszcza Starzewskiego, dla wygody rybaków, bowiem było daleko do kościoła parafialnego. Była aprzy tej kaplicy szkoła, gdzie podstawowych zasad wiary uczył Roch z Wenczyt Herodyski. Dawny dom proboszcza spalił się w 1760 r., ale parafianie wystawili nowy. Opis pozostałych zabudowań plebańskich i uposażenia proboszcza. Spis inwentarza gospodarczego, a także książek, s. 70-74.

W ostatnim roku, w parafii Swarzewo i filii Strzelno ochrzczono 60 osób, ślubów było 14, zaś pogrzebów 16 . W całej parafii naliczono mężczyzn 624 , kobiet 714, chłopców 184, zaś dziewcząt 195. Parafią i filiami administrował Mikołaj Dąb, pochodzący z Warmii, liczący 52 lata, ustanowiony proboszczem z kolacji monarchy w 1742 r., rezydujący na miejscu. Wikariusz Jan Makowski, pochodzący z Gdańska, liczący 52 lata, gorliwy i też przy parafii przebywający. Organi- 
sta Wawrzyniec Kruza, będący też nauczycielem. Witrykusami byli: Adam Klotz, Jan Sztuk, Jan Głębin, Michał Wenda i Jan Jeka. Pięć akuszerek znało swoje powinności. Przytułku dla ubogich nie było, s. 74-76.

Stan kościoła filialnego w S tr z e ln i e.

Była to wieś królewska. Kościół filialny pod wezwanie św. Marii Magdaleny, drewniany, w stanie znacznego zniszczenia. Dzwonnica z trzema dzwonami. Opis stanu wewnętrznego świątyni. Ogólnie stwierdzono, że należałoby ją odbudować od fundamentów. Kościół miał dochód jedynie z ofiar składanych podczas nabożeństw i z pogrzebów. Za ich gromadzenie w skarbonie odpowiadali witrykusi Jan Muza, sołtys z Miruszyna i Jakub Chmielińki, wieśniak ze Strzelna. W świątyni znajdował się jeden ołtarz św. Marii Magdaleny, z tabernakulum gdzie przechowywano Najświętszy Sakrament. Opis wnętrza świątyni i wyposażenie w paramenty liturgiczne, s. 76-78.

Uposażenie stanowiły dwa łany ziemi, nadane jeszcze przez króla Zygmunta Augusta, co potwierdził później Władysław IV, s. 78.

Do parafii tej należało dziewięć wsi, skąd pobierano tak dla proboszcza, jak i dla organisty meszne, tu dokładnie określone. Były to wsie: Strzelno, Miruszyno, Tupadły, Ostrowo, Poczernino, Leśniewo, Cetnowo, osada młyńska Czarnowskie oraz wieś rybacka Karwia, s. 78-79.

Dom proboszcza spalił się w 1759 r. i nie został odbudowany. Były za to niektóre zabudowania gospodarcze, użytkowane przez niejakiego Jakuba Hancke, który płacił proboszczowi czynsz. Przy kościele był organista, niepodanego imienia, posiadający donre mieszkanie i wynagradzany przez parafian, s. 79-80.

Stan kościoła filialnego we wsi $Ł$ e b c z.

Też była to wieś królewska, gdzie dawniej była świątynia pod wezwaniem św. Marcina, jako filialna inkorporowana do parafii Swarzewo, która dnia 13 XII 1747 r. została powalona na ziemię przez wichurę, a nawet dzwonnica nie ostała się nawałnicy. Były tam dwa ołtarze, św. Marcina i św. Józefa i co z nich ocalało, zostało przeniesione do Kocioła w Swarzewie. Z kościoła pozostał jedynie fundamenty i ściany murowane. Ostatnio zbudowano drewniana dzwonnicę, na której znajdują się dwa dzwony, zaś trzeci, mały, przechowywany jest w zakrystii w Swarzewie. Pozostałe paramenty przechowywane są w szafie, pozostającej pod opieką sołtysa wsi Bełcz, które zostały tu spisane. Na uposażenie były cztery łany ziemi, jeszcze na mocy nadania jej przez Krzyżaków w 1340 r. Ponadto proboszcz miał prawo połowu ryb, ale mniejszą siecią. Ten przywilej potwierdzili potem królowie polscy. Ta ziemia jest teraz wydzierżawiona. Do parafii należały trzy wsie, a mianowicie Bełcz, Chrapowo i Karwieńskie Błoto, skąd oddawano meszne i inne powinności. Dom dla proboszcza jest stary i mały, inne zabudowania też ze starości bliskie są ruinie. Pewien dochód dawał dom, którego użytkownik był zobowiązany do dzwonienia na Anioł Pański. Pomimo tej sytuacji, powinno się ze składek i z należności za pogrzeby, świątynię odbudować, s. 80-83.

Dekret reformacyjny dla parafii Swarzewo i parafii filialnych Strzelno i Bełcz, wystawiony w Swarzewie 3 II 1766 r., s. 83-84. 


\section{Wizytacja generalna dekanatu lęborskiego}

L ę b o rk. Miasto z kościołem prepozyturalnym, murowanym, pod wezwaniem św. Jakuba Większego, którego kolatorem był monarcha. Opis świątyni, posiadającej pięć ołtarzy. W ołtarzu wielkim tabernakulum i wizerunkiem Chrystusa Ukrzyżowanego. Po prawej stronie był ołtarz Matki Boskiej, a po przeciwnej św. Jana Chrzciciela oraz dwa następne, poświęcone św. Janowi Nepomucenowi i św. Antoniemu Padewskiemu. Opis wyposażenie świątyni w potrzebne sprzęty. Chór z małym organem. Dzwonnica murowana, złączona ze świątynią, przez aktualnego proboszcza gruntownie odnowiona, z dzwonami dwoma, z których jeden był uszkodzony. Były przywileje odpustowe. Zakrystia murowana, s. 97-98.

Spis paramentów liturgicznych, naczyń srebrnych, szat i ksiąg. Cmentarz nie był ogrodzony i brakowało kostnicy, s. 98-99.

Prepozytem był Ignacy Lniński, archidiakon kruszwicki i kanonik koadiutor włocławski, zawsze tu rezydujący, liczący lat 44 . Wikariuszami, pracującymi tak przy kościele prepozyturalnym, jak i przy kościołach filialnych byli Wawrzyniec Michnowski, lat 56, szczególnie pracujących duszpastersko wśród innowierców oraz Mateusz Bähr, lat 41, także gorliwie pracujący wśród dysydentów. Innowiercy też byli witrykusami tak przy kościele parafialnym, jak i przy filialnych. A więc w Lęborku Jan Grube, mieszczanin i kupiec, przy filialnych zaś Jan Hempell i Maciej Bleck, także mieszczanie i kupcy. W dekanacie byli kapłanami tylko ci, wyżej wymienieni. Nie było przytułku, s. 99-100.

Opis uposażenia parafii oraz dziesięciny z wsi parafialnych Muszyce i Kambłowo. Parafia liczyła mężczyzn katolików 25 osób, kobiet - 27, chłopców - 18 i dziewcząt - 21. W dekanacie lęborskim żyła znaczna ilość Żydów i kalwinistów. Luteran było bardzo duża i mieli oni 17 swoich zborów, s. 100.

Dom prepozyta, podobnie jak i wikariusza, bardzo stare i bliskie ruiny. Brak było domu dla prebendarzy, kaznodziei, nauczyciela i zakrystianina. Organista, Ludwik Więcki był zakrystianinem i kantorem, s. 100-101.

Stan kościoła w N ow e j W s i ${ }^{9}$ (Neudorffensis).

Świątynia murowana, pod wezwaniem św. Katarzyny. Zakrystia, znajdująca się po prawej stronie, także murowana. Ołtarz jeden, drewniany, bez portatylu, z obrazem patronki św. Katarzyny. Nabożeństwa odbywają się ty dwa razy w roku, bowiem nie ma tu katolików. Dzwonnica murowana w pruski mur, z trzema dzwonami. Do tej parafii należało, według dawniejszych wizytacji, sześć łanów ziemi, ale zostały zabrane przez innowierców, którzy dają niewielką tylko zapłatę. Dziesięcina jedynie z wsi parafialnej. Wyliczono dokładnie pewne powinności oddawane prepozytowi lęborskiemu. Na mocy zapisów kościół ten otrzymuje 2499 florenów, s. 101-102.

Stan kościoła filialnego G a r c z e g o r z e.

Świątynia pod wezwaniem św. Marii Magdaleny, jak to informują dawne wizytacje, ponieważ aktualnie znajdują się tu ruiny kościoła. Pozostały jedynie dwa dzwony zawieszona na belkach drewniany, trzeci zaś dzwon został zabrany do

\footnotetext{
${ }^{9}$ Obecnie Nowa Wieś Lęborska.
} 
zboru luterańskiego, za który dopiero teraz urzędujący kaznodzieja innowierczy zamierza zapłacić. Dom proboszcza i inne zabudowania są w ruinie, ale używa ich dzierżawca, płacąc czynsz. Do parafii powinny należeć wsie Garczegorze i Tekla i folwark Obliwice, ponieważ oddawały one prepozytowi opłaty dziesięcinne oraz inne. Był zapis na sumę 420 florenów, s. 102

Stan kościoła filialnego w $\mathrm{L}$ e b i e n i u.

Świątynia pod wezwaniem św. Michała Archanioła, wystawiona z pruskiego muru, stara. Nie przechowywano w niej Najświętszego Sakramentu. Jeden ołtarz. Bardzo skąpe wyposażenie w paramenty liturgiczne. Uposażenie w dwa łany ziemi, w dzierżawie pewnego mieszkańca wioski, za co płacił 24 floreny. Mieszkańcy z tytułu dziesięciny oddawali świadczenia w naturze. Zabudowań plebańskich nie było. Nie było też żadnych zapisów, s. 102-103.

Stan kościoła filialnego w B i ał o g a rd zi e.

Świątynia pod wezwaniem Oczyszczenia Najświętszej Marii Panny, ostatnio, przez aktualnego proboszcza, od fundamentów, z pruskiego muru wystawiona. Ołtarz jeden, stary, pewnie z poprzedniej świątyni. Nabożeństwa były sprawowane w co trzecią niedzielę. Nie przechowywano Najświętszego sakramentu, ani nie udzielano tu chrztu. Skromne wyposażenie w paramenty liturgiczne. Własność parafii, dom plebański i grunta, wydzierżawione. Według wykazów oddawanych powinności dla proboszcza, do kościoła tego przynależały, oprócz samej iejscowości parafialnej, jeszcze wsie Krampa, Trynst Królewski, Londechowo, Garcz, Wick, Skarszewo , Brześć, Kraszewo, Neznechowo, Roszczyce, Maszewo, Zdrzewno, Koponiewo i Strzyżewo. Był zapis na parafię w sumie 100 florenów, s. 103-104.

Stan kościoła filialnego w R o zła z i n i e.

Świątynia została przez aktualnego proboszcza, Ignacego Niskiego, odbudowana od podstaw z pruskiego muru. Przyległa do kościoła wieża służąca jako dzwonnica jest stara, ale jest już zgromadzony materiał przez zarządzającego parafią i należy się spodziewać, że zostanie odnowiona. Swiątynia nosi wezwanie św. Wojciecha. Ołtarz główny, z wizerunkiem Chrystusa Ukrzyżowanego i tabernakulum, gdzie przechowywano N najświętszy Sakrament. Zakrystia i ściana frontowa świątyni, też z pruskiego muru. Dwa ołtarze boczne, św. Wojciecha i po lewej stronie Matki Boskiej. Chrzcielnica syara, ale czysta z woda chrzcielna. Oleje starannie przechowywane w zakrystii. Spis wyposażenie w paramenty liturgiczne, s. 104-105.

Na uposażenie składały się zabudowania plebańskie i grunta w Rozłazinie, znajdujące się w dzierżawie. Ponadto powinności parafialne oddawały wsie: Lubowic, DąmbrówkaNawoże, Osiek, Kętrzyno, Giżewo, Boże Pole, Paraszyno, Chmielowiec, Wilestowo i Gnojno, s. 105.

Przy kościele tym stale rezydował Wawrzyniec Michnowski, wikariusz lęborski, dla większej wygody parafian katolików, tu mieszkających, s. 105-106.

Stan kościoła filialnego w B r z éz n i e ${ }^{10}$. Świątynia drewniana, pod wezwaniem św. Małgorzaty, ostatnio od fundamentów odbudowana. Ołtarz nowy po-

${ }^{10}$ Obecnie Brzeźno Lęborskie. 
święcony Matce Bożej. Nie przechowywano tu Najświętszego Sakramentu, olejów i nie było chrzcielnicy. Nabożeństwa w co czwartą niedzielę. Opis stanu świątyni. Dzwonnica drewniana z trzema dzwonami, zaś czwarty, duży, był pęknięty. Opis zabudowań plebańskich, częściowo przez aktualnego rektora odbudowanych. Uposażenie, składające się z czterech łanów oraz zabudowania wyżej wspomniane $\mathrm{w}$ dzierżawie. Następujące wsie oddawały powinności proboszczowi, a więc, Brzeźno Królewskie, Wielkie Pole, Śliwno, Kaczewo Królewskie, Łączyce, Rekowo, osada młyńska Mędrzyno i Brzeźno, Kissowi, Strzelęcino i Albeka. Był zapis na 170 florenów, s. 106-107.

Dekret reformacyjny dla prepozytury lęborskiej, wystawiony w Lęborki, dnia 10 II 1766 r., s. 107-108.

\section{Wizytacja generalna dekanatu mirachowskiego}

B e rn a czyli Ko ś c i e r z y na $a^{11}$. Wizytacja odbyła się 10 III 1766 r. Miasto (civitas) Kościerzyna posiada kościół pod wezwaniem Świętej Trójcy, murowany, zbudowany w 1642 r., ponieważ stary kościół, wraz z całym miastem, spalił się podczas zamieszek wewnętrznych. Dokument erekcyjny kościoła został wpisany w aktach Konsystorza Generalnego Gdańskiego w 1680 r., którego dosłowny odpis był przechowywany. Prawo patronatu należało do króla. Ołtarzy było cztery. Wielki Świętej Trójcy, z tabernakulum, a światło przed Najświętszym Sakramentem, zawsze się paliło. Relikwie świętych w relikwiarzu, z poświadczeniem z 1755 r., że mogą być wystawiane ku publicznej czci. Przywileje odpustowe. Ołtarz boczny ze strony prawej św. Józefa, po przeciwnej zaś Matki Boskiej Różańcowej. Trzeci zaś nosił wezwanie Świętego Krzyża. Nie było obrazu łaskami słynącego. Zakrystia po stronie ewangelii, gdzie znajdowały się paramenta liturgiczne, dosyć dokładnie wyliczone, s. 109-111.

Bractwo Różańcowe, założona w 1642 r., posiadające własne uposażenie, tu dokładnie wyliczone, s. 111-113.

Opis wnętrza świątyni oraz wyglądu zewnętrznego. Dzwonnica murowana, z trzema dzwonami. Ogrodzenie cmentarza częściowo uszkodzone. Kostnica drewniana, s. 113.

Dochód na utrzymanie świątyni z ofiar składanych podczas nabożeństw i opłat pogrzebowych. Ponadto był dochód $\mathrm{z}$ folwarku zwanego Pierzczewko, jeszcze na podstawie nadania z czasów krzyżackich. Do tego folwarku należała dawniej karczma zwana Kruzina, którą w 1664 r. dawniejszy proboszcz, Andrzej Laurynowicz, zamienił ze starostą kościerzyńskim, Denhoffem za pewien obszar gruntów. $\mathrm{Z}$ folwarkiem tym złączone było pro połowy ryb w sąsiednich jeziorach, większym i mniejszym, zwanym Wędziebno. Teraz część jest pobierana przez Kartuzów, część zaś idzie do skarbony kościoła, pod opieką witrykusów, którzy, razem z proboszczem mają klucze, s. 113-114.

Do parafii należały następujące miejscowości oddające należne powinności: Miasteczko Kościerzyna i wsie Szydlice, Skarżewo, Nowa Wieś, osada młyńska

\footnotetext{
${ }^{11} \mathrm{~W}$ protokole najczęściej używano nawy Berna, ale w repertorium używano Kościerzyna.
} 
kościerska, Lubiana, Kaliska, Fiszrowa Huta, Szenejda, BarkoczynStary, Barkoczyn Nowy, Pustkowie Pieprznika z młynem, Waglikowice, Sarnowy, Czętkowio, Mikorzyn, Szymbark, Skarżewo, Klincz z młynem, Owśnice, Skarszewek, Czarnina. Następujące wsie nic nie oddawała: Juszki, Szklana Huta, Stara Huta Czarlińska, Stara Huta Sikorska, Huta Zielenina, Dąbrówka, Gościerzec, Zimne Zdroje, Wątpie, Mieska Huta, Rybaki, Rote4mberk, Dobrogoszcz. Katolików w parafii było 1100 osób, którzy spowiadali się na Wielkanoc. Mężczyzn naliczono 560, kobiet 540, chłopców 50 i dziewcząt 57. Luteran było 300 i posiadali oni dwa zbory we wsi Szymbark i Barkoczyn. Kalwinistów nie było, ale za to sporo Żydów, którzy mieli swoja bożnicę. Na przedmieściu stała kaplica, niżej opisana. Kaplica prywatna na dworze kościerzyńskim, gdzie odprawiano msze, s. 114-115.

Ponieważ dom proboszcza chylił się ku upadkowi, dlatego staraniem parafian i prepozyta zbudowano nowy, ale pozostający jeszcze do należytego wykończenia. Nie było domu dla wikariusza czy innych duchownych. Służba kościelna, a więc organista $\mathrm{i}$ kantor $\mathrm{w}$ jednej osobie, oraz zakrystiana i nauczyciela też $\mathrm{w}$ jednej osobie, był dom. Opis innych zabudowań gospodarskich. Proboszcz miał folwarczek Pierszczewko. Uposażenie stanowiły cztery łany ziemi. Wykaz dochodów, s. 115-116.

Proboszcz Andrzej Zelewski, dziekan Prachowski, li 59 liczący, w parafii od 1764 r. z prezenty królewskiej. Wikariusz Walenty Pieczewski, będący też kaznodzieją. Promotorem bractwa był sam proboszcz. Organista Andrzej Kurkowski. Nauczyciel Jan Wyder. Witrykusami byli: Bartłomiej Pelowski, Bartłomiej Kleszczyński. Trzy zaprzysiężone, ale niewiadomego imienia, akuszerki. Przytułek znajdujący się na cmentarzu, z trzema podopiecznymi, posiadający własne uposażenie, ale osobnej świątyni, ani kapelana nie posiadający., s. 116-117.

Kaplica drewniana, pod wezwaniem św. Doroty, na przedmieściu, z trzema ołtarzami, chórem muzycznym z pozytywem. Opis jej wnętrza. Cmentarz dobrze ogrodzony. Był przywilej odpustowy na uroczystość Świętego Krzyża i św. Barbary, s. 117-118.

Dekret reformacyjny dla kościoła prepozyturalnego, wystawiony w Kościerzynie, dnia 18 III 1766 r., s. 118-119.

L u z i n o. Wizytacja dnia 7 II 1766 r. Wieś należąca do klasztoru norbertanek z Żukowa. Świątynia murowana, której budowę rozpoczęto w 1734 r., Kidy proboszczem był, nieżyjący już, Maciej Rzepczyński. Opis wnętrza świątyni i jej wyposażenia. Chór muzyczny z małym organem, ale bardzo starym. Dzwonnica murowana, nieco naprawy potrzebująca, $z$ trzema dzwonami. Kościół nosi wezwanie Wniebowzięcia Najświętszej Marii Panny, ale nie był jeszcze konsekrowny. Patronat należał do zakonnic z Żukowa. Świątynią administrował, instalowany przez dziekana puckiego i prepozyta wejherowskiego, Antoniego Langhannik, dnia 8 VII 1758 r., Grzegorz Adam Plutowski. W parafii stale rezyduje. Zaprowadził 2 VII 1759 r. bractwo Różańcowe, Imienia Jezus i Matki Boskiej, którego uposażenie fundował Jakub Dąbrowski z Dąbrówki. Drugim było bractwo św. Jana Nepomucena, dnia 16 V 1760 r. założone i przez samego proboszcza uposażone. Bractwa te otrzymały przywileje odpustowe złączne z niektórymi świętami, 
tu wyliczonymi. Jednakże to uposażenie bractw może dotyczyło samego ich utworzenia, ponieważ zaraz powiedziano, $\mathrm{z}$ tak bractwa, jak i sam kościół specjalnego uposażenie nie posiadają. Kościół jedynie ma ofiary składane podczas nabożeństw z kazaniem oraz opłaty z racji pogrzebów. Wyliczono tu, jakie opłaty pobierano, s. 120-121.

W Świątyni było pięć ołtarzy. Wielki z obrazem Matki Boskiej z Dzieciątkiem. Miał przywilej odpustu za zmarłych, o który wystarał się biskup Antoni Sebastian Dembowski w 1760 r. Znajdowały się relikwie kilku świętych, a nawet Świętego Krzyża. Na niektóre były dokumenty autentyczności. Obok tego ołtarza była zakrystia. W prezbiterium znajdowały się jeszcze ołtarze św. Szczepana, Pierwszego Męczennika i drugi św. Antoniego z Padwy. Ponadto były jeszcze dwa ołtarze - św. Jana Nepomucena i św. Wawrzyńca. Pozostałe wyposażenie świątyni. Księgi parafialne starannie prowadzone. W świątyni znajdowały się stacje Drogi Krzyżowej zaprowadzone przez zakonników franciszkanów reformatów. Nie było żadnej, ale dawniej zapisano, z w pobliżu karczmy, zwanej Borno, w pobliżu miejscowości Boże Pole, znajdowała się kaplica katolicka, gdzie odprawiał co pewien czas proboszcz z Luzina, ale teraz na tym miejscu akatolicy mają swój zbór, s. 121-123.

Wyposażenie świątyni w paramenty liturgiczne, dosyć bogate, s. 123-125.

Uposażenie parafii w cztery łany ziemi, domy, ogrody, a nawet stawy. Powinności parafialne oddają wsie: Luzino, i osada młyńska Luzino, Gowino, Strzebielino, Dąbrówka z osadami młyńskimi, Milwino, Cząstko, Robakowo, Wyszecino, Bartomino, Kambłowo z młynem, Gościnno, osada młyńska Gościnno, Sopieszyno, Ustarbowo z młynem, Przytoczyno. Parafia liczyła mężczyzn 668, kobiet 646, czyli razem 1314 osób. Chłopców 260 i dziewcząt 262. Luteran zaś mężczyzn 97, kobiet 95, chłopców 45 i dziewcząt 52. Nawróconych a aktualnego proboszcza było 68 osób. Akuszerki były dobrze obeznane ze swoimi powinnościami. Organista należycie uposażony. Przytułku dla ubogich nie było. Zabudowania proboszczowskie, mieszkalne i gospodarcze. Inwentarz gospodarczy sporządzony po śmierci poprzedniego proboszcza Macieja Rzepczyńskiego, przyjęty przez aktualnego, Grzegorza Adama Plutowskiego, s. 125-128.

Dekret reformacyjny dla parafii Luzino, spisany dnia 7 II 1766 r. w Luzinie, s. $128-129$.

S i e r a k o w o. Wieś szlachecka Józefa Łaszewskiego, z kościołem jego patronatu, drewnianym, pod wezwaniem św. Marcina. Pięć ołtarzy. Ołtarz wielki, z obrazem Ukoronowania Matki Boskiej, gdzie było tabernakulum. Po prawej stronie ołtarze św. Jana Nepomucena i św. Marcina, a po przeciwnej Świętego Krzyża i Matki Boskiej. Na światło przed Najświętszym Sakramentem był zapis kolatora Łażewskiego (Łaszewskiego). Były przywileje odpustowe. Zakrystia z paramentami liturgicznymi, tu wyliczonymi. Wyposażenie świątyni w potrzebne sprzęty. Opis zewnętrzny świątyni. Dzwonnica drewniana z trzema dzwonami. Cmentarz ogrodzony, z kostnica. Na utrzymanie kościoła szły jedynie ofiary zbierane podczas nabożeństw i z pogrzebów, s. 130-132. 
Do parafii należały 23 miejscowości, z których oddawano powinności parafialne. Sierakowice, Puzdrowo, Puchlino, Pałubice, Kamienica, Młynki, Gowidlino, Łyśniewo, Zalasowo, Skrzeszewo, Pączewo, Bukowo, Bącka Huta, Szopy, Łączki, Moiz, Huta Miszewska, Kamienka, Połęgowo, Nowalcisko, Kolwina. Ponadto były jeszcze wsie, Mrozy, Nowa Huta. Do spowiedzi wielkanocnych było zobowiązanych 1222 osoby, s. 132-133.

Zabudowania plebańskie i uposażenie proboszcza w grunta i ogrody. Był dawny zapis Karola Bystram i jego żony, Anny z Łaszewskich. Inwentarz gospodarczy. Oprócz wyżej wymienionych źródeł uposażenie, był także dochód 474 florenów rocznie, s. 133.

W ostatnim roku było 61 chrztów, 15 ślubów i 30 pogrzebów. W parafii mężczyzn naliczono 566, kobiet 556, chłopców 281 i dziewcząt 223. Akatolików 1188 osób, s.133.

Parafią zarządzał Franciszek Wejer, liczący lat 30, rezydujący w parafii. Nie było innych kapłanów, ani ubogich przy kościele. Witrykusami byli Jan Drywa, Andrzej Klawikowski, Michał Watluszewski i Wawrzyniec Zakrzewski. Akuszerki należycie pouczone, s. 134.

Dekret reformacyjny dla parafii Sierakowo, wystawiony dnia 15 II, s. 134-135.

S tr z e p c z. Wieś królewska z kościołem drewnianym, pod wezwaniem św. Marii Magdaleny. Kolatorem był monarcha. Opis stanu świątyni. Wewnątrz trzy ołtarze, z których boczne nosiły wezwanie Matki Bożej i św. Jana Nepomucena. Opis wyposażenia w sprzęty kościelne. Dzwonnica drewniana z dwoma dzwonami, s. 136-137.

Opis wyposażenia w paramenty liturgiczne, s. 137-139.

Proboszczem był Jan Gręca, od 1765 r., którego, jak to można poznać z protokoły wizytacyjnego, w parafii nie było. Wikariuszem był Marcin Pellowski. Prowizorami był Ludwik Dominirski, dziedzic dóbr Bengardowo, Antoni Lebiński, dziedzic dóbr Łebnie, zaś witrykusi Tomasz Plaster i Łukasz Czerwonka. Organista Franciszek Kujawski, który był jednocześnie kantore4m, nauczycielem i zakrystianinem, s. 139.

Zabudowania plebańskie i uposażenie parafii, s. 140.

Do parafii należało 30 wsi. Strzepocz, folwark Tłuczewo z młynem, Linia z kolonia, Niepoczołowice, Zakrzewo, Tempcze, Dargolewo, Pobłocie, folwark Smarzyno i osada młyńska, Łebnie, Bengardowo, Lewino, Zamblewo z osada młyńska, Staszewo, DSianowo, folwark Cieszenko, Głuszyno, Młynisko, Miłoszewo, dwór Mirachowo i osada młyńska. Ponadto nowe kolonie, jak Stare Smarzyno, folwark Brodki, Huta Łebińska, Bengargówko, Otalżyno, Boreki, Szopy inaczej Mały Borek, folwark Tempcz Rzepeczki, folwarczek mirzchowski, Zarzniczne zwane Rosochy, Huta Stara Mirachowska, Boncz, wieś i folwark Huta Sianowska, Huta Pomieczyńska, Pomieczyno Mirzchowskie, Heytusz, folwark Mirachowski, skąd nie oddawano powinności, s. 140-141.

Katolików przystępujących do sakraaamentów było 1547 osób, spośród których było chłopców 321, dziewcząt 357. Luteran na Terenia parafii naliczono 118, ale nie posiadali oni własnego zboru. Nie było Żydów, kalwinistów, czy greko- 
katolików. Było sześć akuszerek, wystarczająco pouczonych. Przytułek dla ubogich, drewniany, który miał zapis 1650 florenów, zapisanych przez Zygmunta Szczepańskiego, starostę mirachowskiego, lokowanych na mieście Lęborku, a także inne jeszcze zapisy, s. 141-142.

Inwentarz gospodarczy. Spis książek, s. 142-143.

Stan kościoła filialnego w S i a n o w i e.

Świątynia drewniana, pod wezwaniem Narodzenia Najświętszej Marii Panny. Ołtarz wielki z obrazem Matki Boskiej, a boczne św. Jana Nepomucena i św. Tadeusza. Opis stanu wewnętrznego i w3yposażenisa. Zakrystia drewniana, s. 143-144.

Spis wyposażenie w paramenty liturgiczne. Księgi metryk w parafii Strzepocz. Na potrzeby świątyni są jedynie składane ofiary podczas nabożeństw i z pogrzebów. Witrykusi i organista ci sami co w Strzepczu. Zabudowania plebańskie złe. Na uposażenie proboszcza była pewna ilość ziemi oraz prawo połowu ryb w pobliskim jeziorze., s. 144-146.

Dekret reformacyjny dla parafii Strzepcz i kościoła filialnego w Sianowie, wystawiony w Strzepczu, dnia 13 II 1766 r., s. 146-147.

Goręczyno. Świątynia murowana, pod wezwaniem Świętej Trójcy i Wszystkich Świętych. Prawo patronatu należało do klasztoru w Kartuzach. Ołtarz główny Wszystkich Świętych, z tabernakulum, boczne natomiast pod wezwaniem Świętej Trójcy i Matki Bożej. Zakrystia murowana, gdzie przechowywani paramenty liturgiczne, tu wyliczone. Na potrzeby świątyni szły jedynie ofiary składane podczas nabożeństw, s. 148-150.

Wsie parafialne, z których pobierano meszne. Było ich 10: Goręczyno, Kołpino, Ostrzyce, Runty, Stawkowy, Połuszyno, Potuły, Czaple Nowe, Wyczechowo i Borcz. Było jeszcze 129 wsi, które nie oddawały musznego: Somonino, Ossowa, Kolano, Kartuzy, GrzybnoLeśno, Hoppendorff, Skmuca, Sztarkowa Huta, Kammela, Ekiert, Nowa Wieś, Dypendal, Czarna Huta, Ossenkop, Hilowa Huta, Kapelowa Huta, Karczma Wyczechowska czyli Trądkownica i Koszowatka. Wiernych do spowiedzi wielkanocnej było z tych wsi 800 osób, s. 150.

Dom proboszcza częściowo murowany, częściowo z pruskiego muru. Opis innych zabudowań. Uposażenie proboszcza w cztery łany ziemi, łąki i ogrody. Był pewien legat na dobrach Wyczchowo. Spis inwentarza gospodarczego, s. 150-151.

W ostatnim roku było 83 chrzty, 21 ślubów i 16 pogrzebów. Mężczyzn wyliczono 36, kobiet 44, chłopców 153 i dziewcząt $151^{12}$. Na terenie parafii był klasztor kartuzów. Nie było kaplic publicznych i prywatnych, ani zborów dyssydenckich. Luteran mieszkało około 400 osób, s. 151.

Rektorem kościoła był ojciec h Rykowski, lat 34 liczący, 0od 1765 r. w wtej pqarafii. Organista Jan Kleinowski, Witrykusi Jan Bekier, Maciej Kubowski i Mateusz Magulski. Organista uczył dzieci. Przytułku nie było. Trzy odpowiednio pouczone akuszerki, s. 151-152.

Stan kościoła filialnego w K oł p i n i e.

${ }^{12}$ Liczby te niezrozumiałe, jeżeli się zwróci uwagę, że poprzednio powiedziano, że do spowiedzi było rocznie około 800 osób. 
Wieś ta należała do zakonników kartuzów. Świątynia filialna, murowana, pod wezwaniem Świętego Michała Archanioła. Dokument erekcyjny znajdował się w klasztorze kartuzów. Ołtarz wielki św. Michała Archanioła z tabernakulum, ale Najświętszy Sakrament był tam przechowywany jedynie w Dni uroczyste. Drugi ołtarz nosił wezwanie św. Małgorzaty. Zakrystia murowana z potrzebnymi paramentami, dosyć skromnymi, tu wyliczonymi, s. 152-153.

Dekret reformacyjny dla kościoła parafialnego w Goręczynie i filialnego w Kiełpinie, wystawiony w Goręczynie, dnia 18 litego 1766 r., s. 153-154.

$\mathrm{Ch}$ mi e $1 \mathrm{n}$ o. Świątynia drewniana, pod wezwaniem św. Piotra i Pawła. Prawo patronatu należało do zakonnic z Żukowa. Ołtarz wielki z obrazem Matki Boskiej, słynący łaskami, z tabernakulum. Na światło przed Najświętszym sakramentem był zapis 500 florenów, poczyniony przez dawnego proboszcza z Chmielna, Macieja Kręckiego. Ołtarze boczne św. Mikołaja po stronie prawej i po przeciwnej św. Piotra i Pawła. Zakrystia po stronie ewangelii z części murowanej i części drewnianej, s. 155-156.

Wykaz paramentów liturgicznych, dosyć licznych. Opis wnętrza świątyni i stan u zewnętrznego. Dzwonnica drewniana. Cmentarz nie był należycie ogrodzony. Kostnica drewniana. Na potrzeby świątyni szły jedynie ofiary składane w kościele podczas nabożeństw i z pogrzebów, s. 156-157.

Wsie parafialne oddające powinności: Chmielna, folwark Chmielno, Lampowa Huta, posiadłość zwana Karczemy, osada młyńska Chmielno, Zawory, Remboszewo, Brodnica, Łątczyno, osada młyńska Łątczyno, Cieszenie, Borzestowo, Miechucino, Reskowo, Kożyczkowo, Garcz, Grokowo, Kossy, folwark Smętowo, Lipowiec, Łapawice, Borzestowska Huta. Natomiast takie wsie jak: Brodnica Dolna, folwark Chmielno, Huta Borzestowska, Huta Matczyńska, Kalka i Grzebieniec nie oddawały dziesięcin. Do parafii należała także wieś Kozieczkowo. Katolików, tych zobowiązanych do spowiedzi, w parafii było około 900 osób, s. $157-158$.

Opis stanu zabudowań plebańskich, uposażenia w cztery łany ziemi, ogrody, niewiele warty las i prawo połowy w pobliskim jeziorze. Spis inwentarza gospodarczego, s. 158-159.

W ostatnim roku były 53 chrzty, 3 śluby i 20 pogrzebów. Mężczyzn parafia liczyła 447, kobiet 453, chłopców 208 i dziewcząt 150 . Nie było klasztorów, kaplic, czy zborów innowierczych. Akatolików około 90 osób, s. 159.

Proboszczem był Mateusz Kuchtowski, lat 56, w parafii od 1756 r. Innych kapłanów nie było. Organista Józef Trowski. Witrykusi Stefan Deyk, Michał Adamczyk, Krzysztof Okrey. Dziewięć akuszerek należycie przygotowanych. Stary przytułek, zbudowany niegdyś przez proboszcza Kręckiego, w którym było pięciu podopiecznych. Mieli oni czynsz z 500 florenów, zapisanych na klasztorze w Żukowie, przez fundatora, wspomnianego wyżej Kręckiego. Kapelana własnego przytułek nie posiadał, s. 159-161.

Dekret reformacyjny dla parafii w Chmielnie, wystawiony tamże przez wizytatora, dnia 15 II 1766 r., s, 161. 
G r a b o w o. Kościół murowany, pod wezwaniem św. Anny, prawa patronatu zakonników kartuzów. Opis wnętrza świątyni, z trzema ołtarzami. Ołtarz główny św. Anny i boczne św. Szymona i Ścięcia św. Jana Chrzciciela. Zakrystia murowana. Spis dosyć skromnego wyposażenie w paramenty liturgiczne. Opis wnętrza świątyni i stanu zewnętrznego. Dzwonnica murowana, stojąca osobno, wyniosła, niczym wieża, z dwoma dzwonami. Cmentarz dobrze ogrodzony, ale brak kostnicy. Utrzymanie świątyni należało do parafian, kolatora, z udziałem ofiar z racji kolekty i pogrzebów, s. 162-164.

Do parafii należało 15 wsi, a mianowicie Grabowo z osadą młyńską, Kłobuczyzno, Grabówko, Grabowska Huta, Fust Huta, Sztoprowa Huta, Osekop, Szpon, Kamionki, Ansterbank, Burchow. Ponadto od 11756 r. włączono do parafii wsie będące własnością Antoniego Knińskiego, mianowicie Dolne Arnyki, Górne Arnyki i Parowy. Katolików w parafii było 150, którzy przystępowali do sakramentów wielkanocnych, s. 164.

Dom proboszcza, z pruskiego muru, nowo wystawiony przez kolatora. Innych domów dla służby kościelnej, czy wikariusza nie było. Jedynie organista miał mieszkanie. Były zabudowania gospodarcze. Opis ogrodów należących do proboszcza oraz czterech łanów ziemi. Parafianie nie dawali dziesięciny, a tylko meszne. Wykaz inwentarza gospodarczego, s. 164-166.

W ostatnim roku były 25 chrzty, 7 ślubów i 3 pogrzeby. Ogółem mężczyzn naliczono 75 , kobiet 75 , chłopców 20 i dziewcząt 18 . Luteran było na terenie parafii 398 osób, s. 166.

Rektor kościoła Antoni Bobrucki, liczący lat 44. Oprócz parafii Grabowo miał także parafię Rekowice w dekanacie tczewskim. Organista Franciszek Plichtowski. Witrytusi Maciej Lipka, Mikołaj Strompski i Antoni Bober. Było kilka akuszerek, ale nie wszystkie potrafiły udzielać chrztu, s. 166-167.

Dekret reformacyjny dla parafii Grabowo, wystawiony na miejscu dnia 21 II 1766 r., s. $167-168$.

L i p u s z. Wieś królewska z kościołem drewnianym, wystawionym od nowa w 1739 r., pod wezwaniem św. Michała Archanioła, nie konsekrowanym, a jedynie poświęconym za zgoda Konsystorza Gdańskiego przez proboszcza. Kolatorem był król. Ołtarz wielki Matki Boskiej z tabernakulum, gdzie przechowywano Najświętszy Sakrament. Było kilka przywilejów odpustowych, w tym także dla bractwa różańcowego. Ołtarze boczne Świętej Trójcy i św. Michała Archanioła. Obraz Matki Boskiej, który noszony był w procesji, uważano za łaskami słynący. Zakrystia po stronie ewangelii. Wykaz znajdujących się tam paramentów. Na chórze muzycznym pozytyw. Metryki spisywano należycie, a także księgę dochodów i wydatków. Opis stanu zewnętrznego świątyni. Trzy dzwony. Cmentarz należycie ogrodzony z kostnicą. Na potrzeby kościo0ła było 8 florenów z czynszu za jeden domek z ogrodem i ofiar, s. 169-171.

Wsie parafialne: Libusz, Kalisz, Juszkowy, Skwierawy, Gostomek, Radun, Dziemiony, Scybur, Wirowno, Trawice, Trzonka, Dywan, osada młyńska zwana Pech, osada młyńska Kalisz, nowa kolonia Jabłuszek, Śluza, folwarczek Zdroje, Lorync. Katolików dorosłych, z których wszyscy spowiadali się na Wielkanoc 
było ogółem 924 osoby. Mężczyzn 447, kobiet 477, chłopców 139 i dziewcząt148. Luteran na Terenia parafii znajdowały się 102 osoby. Nie było kaplic, ani zboru protestanckiego. Misje ostatnie w 1743 r. przeprowadzone przez jezuitę Jana Łąka, s. 171-173.

Dom proboszcza stary i chylący się ku ruinie. Organistówka stara i także wymagająca naprawy. Inne zabudowania gospodarcze i opis ziemi posiadanej przez proboszcza, a więc ogrody i cztery łany ziemi, łąki z jeziorkiem zwanym Księże, a także las rosnący na gruncie proboszczowskim, z drzewami różnej starości, zdatnymi na budulec, ale prawo do tych drzew miał starosta z Kościerzyny. Nie było dziesięcin, a jedynie meszne, s. 173-175.

W ostatnim roku było 64 chrztów, 13 ślubów i 18 pogrzebów. Rektorem kościoła Był Michał Klimbowski, lat 50 liczący, w parafii od 1763 r. Miał około 30 książek własnych. Nie było wikariusza, ani innego kapłana. Organista Antoni Trepkowski, będący jednoczesnie nauczycielem, kantorem i zakrystianunem. Witrykusi Krzysztof Lamkowski, i Maciej Nozka. Oprócz nich byli starsi bractwa, Łukasz Plata i Jakub Sokołowski. Uczniów było jednie dwóch, których uczył podstaw wiary i czytania organista. Trzy akuszerki potrafiące $\mathrm{w}$ razie konieczności chrzcić, s. 175-176.

Dekret reformacyjny dla parafii Libusz, wystawiony w Lipuszu, dnia 16 III 1766 r., s. 176.

S tę ży c a. Wieś dziedziczna z kościołem murowanym, pod wezwaniem św. Katarzyny, konsekrowana przez sufragana warmińskiego Remigiusza Łaszewskiego w 1738 r. Kolatorem był dziedzic dóbr Stężyca Jan Jezierski, sędzia ziemski tucholski. W kościele znajdowało się pięć ołtarzy. Ołtarz wielki z tabernakulum, pod wezwaniem patronki św. Katarzyny. Ołtarze boczne nosiły wezwania: Świętego Krzyża, Matki Boskiej, św. Jana Nepomucena i św. Antoniego Padewskiego. Uważano, że znajdujący się tam wizerunek Ukrzyżowanego był laskami słynący, ale urzędowego stwierdzenia nie było. Uważano, z znajdowała się relikwia cząstki Krzyża Świętego. Znajdowały się także inne relikwie. Były przywileje odpustowe. Zakrystia murowana po stronie ewangelii. Spis znajdujących się tam paramentów. Nie było spisu inwentarza. Tu wyliczono inwentarz gospodarczy. Wykaz aniwersarzy i innych zobowiązań z mocy poczynionych dawniej zapisów. Wykaz tych legatów. Prowadzono księgę ochrzczonych, jednak nie w sposób przepisany przez prawo. Imiona zmarłych zapisywano, ale też nie w specjalnej księdze. Dalszy opis stanu wewnętrznego i zewnętrznego świątyni. Dzwonnica osobna, murowana z czterema dzwonami. Cmentarz nie całkiem był ogrodzony. Kostnica drewniana dobra. Na kościół szły jedynie składane ofiary, s. 177-181.

Wykaz wsi parafialnych, których było 26, łącznie z folwarkami i miejscami opuszczonymi, $\mathrm{z}$ dokładnym podaniem powinności dla proboszcza: Stężyca i osada młyńska, Pażęcie, Gostomie, Niesiołowice, Misiszewice, Kamienica, Borucino, Zoromino, Przewóz, Zgorzałe, Czaple z osadą młyńską, Gołubie, Pieszczewo, folwarczek Stężyca, Pieszczewko, Stężyca Huta, Klukowa Huta, Przerowie, Nowa Wieś, Sznurki, dwa folwarki Łosińce, Huta Kamińska, folwark Jana Grobla, Osika, Nizinko. Katolików w parafii było 905 osób spowiadających się na Wiel- 
kanoc, z czego mężczyzn 401, kobiet 504, chłopców 162 i dziewcząt 189 . Z innych wyznań jedynie byli luteranie w liczbie 223 osoby. Ostatnie misje w $1754 \mathrm{r}$, s.181-183.

Zabudowania plebańskie stare. Opis uposażenia w ogrody, i cztery łany ziemi, a poza tym łąki. Nie było lasu, ani stawów. $Z$ innych dochodów jedynie te $\mathrm{z}$ legatów wyżej wspomnianych. W ostatnim roku było chrztów 42, ślubów 14 i pogrzebów 22. Nie było innych kościołów, kaplic, ani zborów protestanckich., s. 183-184.

Rektor kościoła Wojciech Wiconowski, lat 41 liczący, od 1764 r. w tej parafii. Rezydował na miejscu. Wikariusz Mateusz Kulaszewicz, organista Szymon Gaszłowski, który pełnił obowiązki kantora, nauczyciela i zakrystianina. Witrykusi Michał Tuziński, Marcin Szczuba, Bartłomiej Kozik. Przytułek w ruinie, ale było w nim trzech ubogich, a dla ich utrzymania był pewien zapis, s. 184-185.

Dekret reformacyjny, wystawiony dnia 22 II 1766 r. w Stężycy, s. 185-186.

\section{Wizytacja generalna dekanatu bytowskiego przeprowadzona w 1766 roku}

B y tó w. Miasto (oppidum) i historia jego powstania. Kościół katolicki prepozyturalny, spalony w w 1770 r., dzięki biskupowi włocławskiemu Felicjanowi Konstantemu Szaniawskiemu od fundamentów jako murowany odbudowany, posiadający 12 okien, których szyby notorycznie są wybijane przez dzieci akatolików. Nie wiadomo kiedy był erygowany tu kościół pod wezwaniem św. Katarzyny. Kolatorem był król pruski. W świątyni tej nie było ołtarzy bocznych, a jedynie ołtarz wielki poświęcony patronce św. Katarzynie, z tabernakulum. Był przywilej odpustowy. Nie było obrazu łaskami słynącego ani w tej świątyni, ani w innych, doń afiliowanych. Zakrystia po stronie ewangelii, murowana, nieco zniszczona, a w niej przechowywano paramenty liturgiczne, tu wyliczone. Chór muzyczny ze starym pozytywem. Za obecnego proboszcza spisywano metryki. Opis zewnętrzny kościoła. Dzwonnica osobno stojąca z jednym dzwonem. Cmentarz wprawdzie z uszkodzonym ze starości ogrodzeniem, ale nie był sprofanowany przez akatolików. Kostnicy nie było. Na utrzymanie świątyni były dwa łany ziemi i różne łąki, do daje, wg tego co aktualny prowizor, rajca miejski imieniem Kisner stwierdził, nieznaczny dochód. Były dawne lagaty, ale dochodu aktualnie nie przynosiły. Ponadto pewien dochód przynosiły pogrzeby, gdy dzwoniono w dzwon parafialny, co zapisywali prowizorzy, s. 187-190.

Wsie parafialne parafii bytowskiej, z których oddawano proboszczowi powinności, tu wymienione: Gostkowo Duże i Gostkowo Małe, Dombie, Grzmiąca, Niedarzyno i osada młyńska w tej wsi, Osiek, Pomysk, Dombinowice, Mędrzychowice, Udorff. Następujące wsie przynależały do afiliowanej parafii Niezabyszewo: Niezabyszewo, Dąbrówka (tu także był kościół), Rekowo, Nowa Kolonia, czyli Płotowa. Do afiliowanego kościoła w Tuchomiu należały wsie: Tuchom, Tuchomek, Modrzewo, Trzebiatkowy, Ciemno, Piasno. Z tych wszystkich wsi katolików spowiadało się na Wielkanoc 420 osób, s. 190-191. 
Dom proboszcza bytowskiego bardzo stary i ubogi, wybudowany przez Ludwika Borzyszkowskiego, powinni teraz odbudować parafianie. Innych domów mieszkalnych nie było, a jedynie skromne zabudowania gospodarcze. Oprócz ogrodu, było sześć łanów ziemi, ale były w posiadaniu mieszczan, co dawało niewielki zysk. Był także grunt zwany Worland, także oddany za czynsz. Nie było własnego lasu, ani jeziora, ale było prawo wyrębu drewna i połowu ryb. Ponadto pewien dochód miał proboszcz $\mathrm{z}$ oddanych $\mathrm{w}$ dzierżawę ziem $\mathrm{w}$ afiliowanych parafiach. Nie pobierał już dziesięciny, a jedynie meszne. Parafie afiliowane nie posiadał żadnych zapisów. Inwentarz gospodarczy mówił jedynie o dwóch koniach i to należących do domu proboszcza w Niezabyszewie i niewielką ilość sprzętów. Ogólny dochód proboszcza bytowskiego ze wszystkich parafii wynosił około 1000 florenów w dobrej monecie, s. 191-193.

W ostatnim roku było chrztów w parafii Bytów i Niezabyszewo 22, w Tuchomiu 3, ślubów ogółem 3 i cztery pogrzeby. Mężczyzn ogółem było 190, kobiet 230, chłopców 45 i dziewcząt 65 . W Bytowie, poza miastem, znajdowały się: kaplica św. Jerzego i kaplica świętego Marka, ale na ich miejsce postawiono zbór protestancki. Drugi zbór postawiono w samym mieście., s. 193.

Rektorem kościoła bytowskiego i afiliowanych był Franciszek Jan Węsierski, lat 52 liczący, ale rezydował w Niezabyszewie. Organistów było dwóch. Jeden przy kościele w Niezabyszewie, drugi zaś przy kościele w Tuchomiu, gdzie był nauczycielem, kantorem i zakrystianem zarazem. Witrykusem w Bytowie był Maciej Theniel, w Niezabyszewie szlachcice Krzysztof Wentach Rekowski i Marcin Ciszewski, w Tuchomiu niejaki Wirbus. Aktualnie przy żadnym kościele nie uczono dzieci. Dwie akuszerki, wystarczająco pouczone. Nie było w żadne parafii przytułku, ani kapelana, bo i nie było uposażenia, s. 193-195.

Ni e zaby s zew o. Kościół dawniej parafialny, teraz filia Bytowa, stary z pruskiego muru, pod wezwaniem św. Mikołaja. Ołtarz główny niepodanego wezwania. Były przywileje odpustowe. Jeden ołtarz boczny pod wezwaniem św. Mikołaja. Zakrystia po stronie ewangelii. Wykaz znajdujących się w niej paramentów liturgicznych i innych rzeczy kościelnych. Opis stanu świątyni. Dzwonnica osobna, drewniana z trzema dzwonami. Cmentarz ogrodzony i w pewnej jego części chowają się akatolicy. Na utrzymanie kościoła była pewna ilość ziemi, pół łana z łąką i domek z ogrodem, co dawało niewielki dochód, a także ofiary składane podczas kazania i z pogrzebów, s. 195-196.

Dom proboszcza nowy wystawiony staraniem obecnego proboszcza. Inne niewielkie zabudowania gospodarcze. Na utrzymanie proboszcza były cztery łany ziemi z łąką, dochód z domku wystawionego dawniej przez mansjonarzy, s. 196-197.

T u c h o m i e. Wieś królewska z kościołem drewnianym, pod wezwaniem św. Michała, przez księdza Ryndwelskiego, wówczas proboszcza Boryszkowskiego i kanonika kamieńskiego od nowa wystawiony. Po stronie ewangelii zakrystia z paramentami liturgicznymi, skromnymi, tu wyliczonymi. Ołtarz główny, wystawiony ostatnio z obrazem św. Mikołaja i drugim Zwiastowania Najświętszej Marii Panny Znajdowało się tu tabernakulum, i przechowywano tu Najświętszy sa- 
krament. Wykaz skromny innych sprzętów w kościele. Przywileje odpustowe na św. Michała i Zwiastowania Najświętszej Marii Panny. Na środku kościoła wizerunek Ukrzyżowanego. Chór muzyczny, ale bez instrumentu. Po stronie ewangelii ołtarz pod wezwaniem Ukrzyżowania Pana Jezusa. Opis zewnętrznego wyglądu kościoła, ogrodzonego częściowo cmentarza, na którym chowają się katolicy i akatolicy. Kostnicy nie było. Na utrzymanie świątyni była łąka zwana Kand, co dawało pewien czynsz oraz ofiary podczas kazań z racji pogrzebu, gdy dzwoniono. Dla proboszcza było sześć łanów ziemi, ale teraz już tylko były cztery łany, z łąka, a także dom plebański, ogród z kilkoma zabudowaniami gospodarczymi, s. 197-198.

D ą b r ó w k a. Wieś królewska. Kościół katolicki, afiliowany do parafii Niezabyszewo, z prezbiterium drewnianym i nawą murowana w pruski mur, pod wezwaniem św. Wojciecha, z dzwonnica, zawierająca dwa dzwony. O początkach tego kościoła nic nie wiadomo. Jeden ołtarz pod wezwaniem Jezusa Ukrzyżowanego, ale bez tabernakulum, bo tu ani nie przechowywano Najświętszego sakramentu, ani nie udzielano chrztu. We wsi mieszkali sami akatolicy, stąd nie było tu nabożeństw, a jedynie w co czwartą niedzielę było kazanie dla akatolików (ale nie powiedziano kto je głosił). Na utrzymanie satyni był pół łana ziemi i domek, z czego był czynsz. Dla proboszcza dwa łany z ogrodem i domek, z czego proboszcz miał roczny czynsz, s. 198-199.

Dekret reformacyjny dla kościoła prepozyturalnego bytowskiego i kościołów afiliowanych, wystawiony w Bytowie, dnia 3 III 1766 r., s. 199-200.

U g o s z c z. Wieś królewska, z kościołem św. Marii Magdaleny, drewnianym, zbudowanym w 1736 r., zaś erekcja jest przechowywana na zamku w Bytowie i jak twierdził u aktualny proboszcz, widział ja w Archiwum królewskim. Kolatorem był król pruski. Ołtarz wielki pod wezwaniem Matki Boskiej, z tabernakulum, boczne po stronie ewangelii św. Barbary, po przeciwnej zaś ołtarz Matki Boskiej Różańcowej. Przywileje odpustowe. Nie było obrazu słynącego łaskami ani w Ugoszczu, ani w kościołach filialnych. Zakrystia po stronie ewangelii z paramentami liturgicznymi, tu wymienionymi. Inne sprzęty w kościele. Inwentarz gospodarczy i innych sprzętów w obejściu plebańskim. Metryki spisywano, s. 201-203.

Opis stanu zewnętrznego świątyni. Dzwonnica obok kościoła drewniana z trzema dzwonami. Na cmentarzu chowali się katolicy i akatolicy. Kostnicy nie było przy żadnym z kościołów. Na utrzymanie świątyni powinien był jeden łan ziemi, ale teraz jest na utrzymanie proboszcza. Inny dochód dla świątyni jedynie z ofiar składanych w kościele i z pogrzebów, s. 203.

Wsie parafialne i wykaz pobieranych powinności przez proboszcza: Ugoszcz, Czarna Dombrowa, Osowa Dombrowa, Huminy, Konczno, Prondzonka. Do kościoła filialnego w Borzytuchomiu należały wsie: Borzytuchom, Strzyszewo, Kotkowy, gdzie był też kościół, Kraśniewo, osady młyńskie w Kotkowie, Morsztynowie i Kraśnienie. W tych wsiach było 542 katolików, którzy wszyscy spowiadali się na Wielkanoc, s. 203-205. 
Dom rektora kościoła dobry, wystawiony przez nieżyjącego już zarządcy parafią, księdza Maszyńskiego, chociaż wg prawa obowiązującego w Prusach do zbudowania i utrzymania zabudowań plebańskich są zobowiązani parafianie. Innych domów nie nbyło, poza organistówką. Inne zabudowania gospodarcze. Uposażenie stanowily cztery łany z łąkami i ten jeden, kontrowersyjny, o którym wyżej. Lasu nie było, ale proboszcz miał prawo wyrębu drewna, ponadto stawy gdzie mógł łowić ryby, także i zimą w innych stawach w parafii. Nie było dziesięcin, ani wytycznych, ani pieniężnych, a jedynie meszne. Roczny dochód proboszcza obliczano na 700 florenów, s. 205-206.

W ostatnim roku ochrzczono we wszystkich parafiach, czyli w Ugoszczu i filialnych, 20 osób, ślubów udzielono 3 i pochowano 8 osób. Ogółem było mężczyzn 240, kobiet 302, chłopców 20 i dziewcząt 30. Nie było innych świątyń, poza dwoma zborami luterańskimi, w Borzutuchomiu i Siminach, s. 206.

Rektor kościoła Michał Bartłomiej Kempski, lat 49, od 1764 r. Organista w Uoszczu Jan Rekowski, który pełnił także obowiązki kantora, nauczyciela i zakrystiana. Wtrykusami byli w Ugoszczu i Studzienicach szlachcice Andrzej Kłopotek i Jakub Czerzen. W Borzytuchomiu i Kotkowie Szymon Wróblewski. Nie było uczniów, ani przytułku i ubogich w nim. Trzy akuszerki dobrze przygotowane, s. 206-207.

S t u d z i e n i c e ${ }^{13}$. Świątynia drewniana z fundacji szlacheckiej, przedstawiająca zły widok. Trzy ołtarze. Wielki od wezwaniem Trójcy Przenajświętszej, ale w tabernakulum przechowywano Najświętszy Sakrament, ale tylko na korporale, bowiem obawiano się, że puszka srebrna i złocona, która stanowiła własność tego kościoła, byłaby okazja dla złodzieja. Zakrystia po stronie ewangelii, gdzie przechowywano paramenta. Na cmentarzu, ogrodzonym, chowali się sami katolicy. Kostnicy nie było. Bractwo Różańcowe, które z zapisu Rekowskiego miał na uposażenie nieco ziemi sąsiadującej ze wsią, z czego był minimalny dochód. Syn tego Rekowskiego, Maciej zapisał na bractwo jeden łan, z czego było rocznie 24 floreny dochodu. Dzielono go w ten sposób, że proboszcz brał na msze rocznie florenów 10 , organista 4 , a pozostałe 10 szło dla chorych braci i sióstr bractwa, s. 208-209.

B o r z y u chom. Kościół filialny drewniany, zwyczajem pruskim wystawiony, pod wezwaniem Zwiastowania Najświętszej Marii Panny. Ołtarz jeden pod wezwaniem Wniebowzięcia Matki Boskiej, ale nigdy tu nie przechowywano Sanctissimum. Zakrystia po stronie ewangelii, gdzie przechowywano skromne paramenta. Stara i bardzo artystycznie wykonana figura matki Boskiej, znajdująca się na środku kościoła obok Krzyża. Dzwonnica drewniana i zniszczona z dwoma dzwonami, które dzwonią także, gdy ma byś nabożeństwo akatolików w ich zborze. Na cmentarzu, dobrze zamkniętym, chowają się tez akatolicy. Opis uposażenia kościoła w łąkę zwana Chmielnik, pewna ilość ziemi we wsi Strzyszewo i po-

${ }^{13}$ Studzienice znajduja się obecnie w parafii Ugoszcz i jest tam kościół filialny pod wezwaniem Trójcy Przenajświętszej. 
siadłość znajdująca się pomiędzy polami sołtysa strzyżewskiego i sołtysa wsi Dombrowa. Jest też domek, w którym mieszka Szymon Wróblewski, prowizor kościoła i kantor. Pewne wynagrodzenie dają akatolicy z korzystania z dzwonów. Dla proboszcz zaś było sześć łanów z łąkami i ogrodami, co dawało roczny dochód. Dzierżawcami posiadłości plebańskich byli: Jakub Wrecza, Jerzy Jank, Marcin Wrecza. Szymon Wróblewski, kantor i prowizor miał jeszcze dodatkowe wynagrodzenie, tu wyliczone, s. 210-211.

K o t k o w o. Wieś królewska z kościołem filialnym parafii Ugoszcz, w roku ubiegłym od podstaw odbudowanym z pruskiego muru, ale jeszcze wnętrze nie było należycie urządzone, bo jedynie znajdowała się ambona i dwie ławki, bardzo stare, znać ze starego kościoła wzięte. Ołtarza nie było jedynie sama mensa murowana. Nie podano wezwania świątyni. Do tego kościółka, bo użyto także tego określenia, była przyległa dzwonnica z dwoma dzwonami. Na uposażenie jej były dwie morgi ziemi zwane Księże Kawle, leżące w kierunku wsi Strzyszewo oraz marga zwana Kawel, łąka w kierunku wsi Modrzewo, a także łąka niedaleko fabryczki zwanej Nowa Huta. Z tego proboszcz ma roczny czynsz. Ponadto był zapisany pewien fundusz, który teraz rozumiany jest jako parafialny, ale z niego i domu i innych zabudowań, zbudowanych niegdyś przez Marcina Gola, czynsz idzie do skarbu króla pruskiego, s. 211-212.

Dekret reformacyjny dla parafii Ugoszcz, wystawiony 5 III 1766 r., s. 212.

B r u s y. Wieś królewska. Kościół pod wezwaniem Wszystkich Świętych, ze starości w stanie bardzo zniszczonym, ale w t tym roku ma być wystawiony nowy i było już zebrane potrzebne drewno i inne materiały. Kolatorem był król polski. Opis wnętrza tej świątyni. Ołtarz wielki pod wezwaniem Wniebowzięcia Najświętszej Marii Panny z tabernakulum, gdzie przechowywano Sanctissimum. Ołtarze boczne zaś nosiły wezwania Wszystkich Świętych i Trzech Króli. Zakrystia po stronie ewangelii. Wykaz dosyć bogatego zbioru paramentów liturgicznych i innych rzeczy kościelnych. Opis stanu zewnętrznego. Dzwonnica drewniana $\mathrm{z}$ trzema dzwonami. Cmentarz ogrodzony z kostnicą. Na utrzymanie świątyni był łan ziemi ofiarowany przez nieżyjącego już Wojciecha Gnacińskiego, z czego był czynsz roczny 24 floreny. Ponadto były ofiary składane podczas nabożeństw i okazji pogrzebów, s. 213-216.

Wsie należące, których było 13. Brusy, Kossobudy, Czyczkowy, Zalesie, Męcikał, Żabno, Małe Chełmy, Wielkie Chełmy z którymi złączone były nowe kolonie o nazwach Stare, Asmus, Młynek i Plesno, Czarnowo, Czapiewice, Glisno, Głowczewice. Ponadko nowe kolonie o nazwach: Olszyny, Giełda, Okręglik, Kłonia, Dąbrówka, Pokrzywno, Turoqwiec, Spiorwia, Drzewicz, Rolnik, Czernica. Katolików spowiadających się było ogółem 1357 osób, s. 216-217.

Dom proboszcza dosyć wygodny. Organista, który pełnił obowiązki kantora, nauczyciela i zakrystiana, miał domek drewniany, nie dawno wystawiony staraniem parafian. Inne zabudowania gospodarcze. Uposażenie proboszcza stanowiły cztery łany ziemi. Proboszcz miał prawo wyrębu drewna. W miejsce dziesięciny, było meszne, dokładnie podane przy każdej miejscowości. Proboszcz posiadał 
także pewien dochód $\mathrm{z}$ filialnej parafii Leśno. $\mathrm{W}$ ostatnim roku było $\mathrm{w}$ Brusach 85, zaś w Leśnie 27 chrztów, ślubów w obydwóch parafiach udzielono 44, zaś pogrzebów 56. Ogółem mężczyzn naliczono 669, kobiet 694, chłopców 112, dziewcząt 153. Luteran było 52 osoby. Nie było innych kościołów, czy kaplic, a tylko kaplica prywatna w dobrach Wielkie Chełmy, gdzie było zezwolenie na sprawowanie mszy, s. 217-218.

Rektor kościoła Piotr Ignacy Niezorawski, lat 60 liczący, parafii od 1758 r., zawsze rezydujący na miejscu. On był też promotorem bractwa Szkaplerza. Nie było wikariusza, chociaż byłby potrzebny. Organista Józef Rabiński, jednocześnie zakrystian, kantor i nauczyciel. Akuszerek dziewięć, wystarczająco pouczonych. Był dom dla przytułku, z uposażeniem 1000 florenów zapisanych przez Piotra Kuberskiego, z czego było 40 florenów dla 10 ubogich. Ten przytułek własnego kościoła nie miał, s.218-22.

L e śn o. Wieś królewska, w ostatnim czasie w posiadaniu rodziny szlacheckiej Lewaldtów-Jezierskich. Kościół drewniany pod wezwaniem Znalezienia Krzyża Świętego, afiliowany do parafii Brusy, nie konsekrowany, a jedynie poświęcony, za zezwoleniem biskupa Włocławskiego Szaniawskiego, przez nieżyjącego już dziekana bytowskiego Szymona Kolińskiego. O starz wielki pod wezwaniem Znalezienia Krzyża Świętego, gdzie przechowywano Najświętszy Sakrament. Trzy ołtarze boczne: po stronie prawej św. Katarzyny, a po przeciwnej Świętego Krzyża oraz jeszcze jeden, nowy, św. Jana Nepomucena. Dwi9e zakrystie, po obydwóch stronach prezbiterium. Spis znajdujących się tam paramentów liturgicznych. Nie było inwentarza gospodarczego. Spis innych rzeczy znajdujących się w świątyni. Dzwonnica drewniana z dwoma dużymi dzwonami. Cmentarz ogrodzony z kostnica. Nie było specjalnego uposażenia na utrzymanie świątyni, a tylko kolekta składana podczas nabożeństw i opłaty z okazji pogrzebów, s. 220-221.

Wsie parafialne do tej parafii filialnej należące i wykaz powinności. Leśno, Lędy,Trzebórz, Radon, Wysoka, Orlik. Było też 12 nowych kolonii, czyli pustkowi. Osady młyńskie Kaszuba, Parzyn, Lamk. Wyndorp, Kruszyn, Skoszewo, Ocymi czyli Tatarki, Pepliński, Laska, Widno, Warszin, Prądzonka. Dom rektora drewniany, wystarczająco dobry. Z zabudowań gospodarczych jedynie mała stajnia i stodoła. Na uposażenie były cztery łany ziemi i łąka, ale w dzierżawie, s. 222.

Katolików w tej filialnej parafii było 907 i wszyscy spowiadali się na Wielkanoc. Było też 25 luteran. Ochrzczonych zostało 27 osób, związków małżeńskich zawarto 22 i pochowano 28 osób. Mężczyzn naliczono 432, kobiet 472, chłopców 93 i dziewcząt 114. Organista był Jakub Ostrowski, jednocześnie kantor, nauczyciel i zakrystian. Trzy akuszerki potrafiące chrzcić w razie potrzeby, s. 223.

Dekret reformacyjny dla parafii Brusy i parafii filialnej Leśno, wystawiony dnia 9 III w Brusach, s. 223-224.

P a r c h o w o. Kościół tu się dawniej znajdujący spalił się, ale w 1666 r. został odbudowany z drewna, z dwiema kaplicami. Według sporządzonego odpisu dokumentu erekcyjnego wiadomo, że parafia erygowana była w 1339 r. zakonnika krzyżackiego Warlabin de Szanfanberk. Kościł nosił wezwanie św. Mikołaja, 
a kolatorem był król polski. Ołtarz wielki pod wezwaniem Wniebowzięcia Najświętszej Marii Panny, z tabernakulum, gdzie był przechowywany Najświętszy Sakrament. Były pewne przywileje odpustowe, w tym także dla bractwa Bożej Opatrzności. Ołtarze boczne były takie. Po stronie lekcji Przemienienia Pańskiego, a po przeciwnej Jezusa Chrystusa Ukrzyżowanego. Ponadto był ołtarz kaplicy matki Boskiej. W kościele tym znajdowała się figura Matki Boskiej Niepokalanej, uważana za łaskami słynąca. Zakrystia po stronie ewangelii. Spis paramentów liturgicznych i innych rzeczy kościelnych w niej przechowywanych, s. 225-227.

Inwentarz gospodarczy, w którym wymieniono dawnego proboszcza Jakuba Małkowskiego i obecnego Jana Erazma Kitowskiego. Opis stanu zewnętrznego świątyni. Dzwonnica z trzema dzwonami. Cmentarz nie znajdował się przy kościele, ale w pobliżu plebanii, gdzie dawniej znajdowała się świątynia, należycie ogrodzony, ale na nim chowali się także akatolicy. Nie było kostnicy, ale miała być zbudowana $\mathrm{w}$ niedługim czasie. Na świątynię nie było żadnego uposażenia, a jedynie ofiary z tacy i z racji pogrzebów, s.227-229.

Wsie z podaniem oddawanych powinności: Parchowo, Gałczewo, Nakla, Sieczno, Jomno, Chośnica, Żukowko, Młynki, Grabowo. Ponadto folwarki Nowy Dwór, Neufeldt, Sucha, Kłodno, Huminy, osada młyńska Jaminense, folwarki Botendorf, Osenkop, Choina, Rzeka, Chośnica, Wygoda. Katolików było 599 i wszyscy się spowiadali na Wielkanoc, s. 229-230.

Dom rektora wystawiony w 1754 przez proboszcza Jakuba Małkowskiego. Nie było innych domów, tylko dla organisty, wystawiony kosztem parafian. Inne zabudowania gospodarcze. Na uposażenie były cztery łany ziemi z łąkami. Lasu nie było, ale miał proboszcz prawo wyrębu drewna. W miejsce dziesięciny proboszcz odbierał meszne. Żadnych legatów nie było, s. 230-231.

W ostatnim roku chrztów było 45, ślubów 13 i pogrzebów 25. Mężczyzn naliczono296, kobiet 303, chłopców 124 i dziewcząt 104. Nie było żądnych kaplic ani świątyń, ale oczekuje się zezwolenia ordynariusza na postawienie kaplicy we wsi szlacheckiej Żukówko, gdzie dawniej była kaplica pod wezwaniem św. Erazma, po której zostały jeszcze fundamenty. Na tę kaplicę były dawne legaty, ale terac ich nie oddawano. Cmentarz na tym miejscu istniejący zajęli akatolicy. Akatolików było 344 osoby, s. 231-232.

Rektor kościoła Jan Erazm Kitowski, lat 46, w parafii od 1763. Wikariusz Jakub Roszkowski, lat 37. Organista Antoni Szefler, jednocześnie kantor, nauczyciel i zakrystian. Prowizorami byli Jerzy Żakowski i Marcin Wróblewsko. Pięć akuszerek wystarczająco pouczonych. Było także bractwo, bliżej nie określone, s. 232-233.

Dekret reformacyjny dla parafii Parchowo, wystawiony na miejscu dnia 1 III 1766 r., s. 233-234.

S u lę c zyno. Wieś dziedzicznaDorpowskich, z kościołem drewnianym, który, według dokumenty erekcyjnego wyjętego z Archiwum Kapituły Włocławskiej, był erygowany w 1616 r. i wtedy był konsekrowany przez biskupa sufragana Franciszka Łąckiego. Nie podano wezwania świątyni. Ołtarz wielki z wizerunkiem Ukrzyżowanego, gdzie przechowywano Najświętszy Sakrament. Odpusty 
na Świętą Trójce i św. Annę z 1754 r. Ołtarze boczne trzy, a więc po prawej stronie Matki Boskiej i Świętej Trójcy, po lewej Obrzezania Pańskiego i św. Anny i ołtarz św. Jana Nepomucena. Zakrystia po stronie ewangelii z przechowywanymi tam paramentami liturgicznymi. Spis inwentarza gospodarczego. Był zapis na dobrach Sulęczyno, poczyniony przez Reinholda Hedelszteyn, sekretarza królewskiego, opiewający na 1500 florenów. Była i druga lokata 500 florenów na tych samych dobrach, przez Kacpra Góreckiego, z czego płynęły pewne obowiązki dla proboszcza. Opis stanu wewnętrznego świątyni i jej wyposażenia oraz stanu zewnętrznego. Dzwonnica drewniana z trzema dzwonami. Cmentarz, za którego ogrodzenie odpowiadają parafianie, pozostawiał wiele do życzenia. Także i kostnica była zniszczona. Na potrzeby świątyni szły jedynie ofiary składane podczas kazań i z racji akcydensów, s. 235-238.

Wsie parafialne, jak to ustalił biskup Wawrzyniec Gembicki, są takie: Sulęczyn, Zdunowie, Żakowo, Podjazdy, Kistowo, Węsiory. Po powstaniu parafii, doszły jeszcze nowe miejscowości, jak Borek, osada młyńska Podjazy, Bielawki, Zdunowie Małe, KistówkoOstrowite, Buskowa Góra. W całej parafii było 560 katolików spowiadających się na Wielkanoc, z czego mężczyzn naliczono 248, kobiet 312, chłopców 86 i dziewcząt 89. Luteran buło 48 osób, s. 238-239.

Dom rektora dobry, bo niedawno wystawiony. Innych domów nie było, a jedynie organista, który był i kantorem i nauczycielem, miał dom zbudowany bardzo dawno przez fundatora. Inne zabudowania gospodarcze. Uposażenie w cztery łany ziemi, prawo wyrębu drewna a także prawo połowy ryb w jeziorze zwanym Skarszyno. Zamiast dziesięcin, było meszne. W ostatnim roku było chów 32, ślubów 3 i pogrzebów 4 . Nie było żadnych światyń katolickich, ani innych wyznań, s. $239-240$.

Rektorem był Józef Antoni Moszarski, lat 67, w parafii od 1`755 r. Wspomniano, że był także promotorem bractwa, o którym jednak nic nie powiedziano. Organista Jakub Szlagowski, witrykusami byli szlachcice Maciej Cieszyca Węgierski i Aleksander Zelewski oraz spośród wieśniaków Paweł Głodowski, Jan Kasa, Wojciech Treder i Grzegorz Marszk. Akuszerki dwie, dobrze wyuczone, a jedna z nich, ze wsi Sulęczyno, imieniem Elżbieta, podczas tej wizytacji złożyła przysięgę. Nie było przytułku, ani uposażenia dla niego, s. 240-241.

Dekret reformacyjny dla parafii, wystawiony w Sulęczynie dnia 26 II 1766 r., s. 242 .

W i e l e. Kościół drewniany, pod wezwaniem św. Mikołaja, prawa patronatu króla polskiego. Ołtarz wielki z obrazem Matki Boskiej i św. Marcina w górnej części. W nim było tabernakulum. Były przywileje odpustowe, także dla bractwa, zapewne św. Anny, na co w parafii było brewe papieskie z 1752 r. Trzy ołtarze boczne, a więc po stronie ewangelii św. Antoniego Padewskiego, niedawno kosztem Franciszka Łukowicz zbudowany. Po przeciwnej stronie nowy ołtarz św. Józefa, wreszcie trzeci, w nawie, po stronie ewangelii, św. Mikołaja. Zakrystia drewniana, po stronie ewangelii. Wykaz znajdujących się w niej paramentów liturgicznych i innych rzeczy kościelnych. Był zapis z 1750 r., uczyniony przez Franciszka Łukowicza na sumę 750 florenów, oraz na sumę 500 florenów, przez 
Tomasza Lipińskiego, proboszcza Rogozińskiego, z czego proboszcz z parafii Wiele miał odprawiać przepisane nabożeństwa. Proboszcz spisywał metryki. Opis stanu świątyni, wewnętrznego i zewnętrznego. Dzwonnica z dwoma dzwonami. Dochód kościoła z ofiar, pogrzebów i zapisów, s. 243-246.

Wsie parafialne z wyliczeniem powinności dla proboszcza: Wiele, Karsin, Górki, Dąbrówka, Przytarnia, Borzk, Miedzno, Cisewie, nowa kolonia Bonk, wieś Odry, Wojtal, karczma Kiszowska, nowa kolonia zwana Puste, wieś Ossowo, Piechowice, Kleczkowy, osada młyńska Broda, nowa kolonia zwana Rodaczka, nowa kolonia Row, nowa kolonia Jastrzębiec, nowa kolonia Zamość. Ponadto wyliczono jeszcze Wdzydze Tucholskie, Wdzydze Kiszewskie, Kolonia Zabrody, Kolonia Lipa, Kolonia Kozłowiec, Kolonia Płazy, Kolonia Czyste, Kolonia Barłogi, Kolonia Kloc. Katolików spowiadających się naliczono 1176 osób, z czego mężczyzn 560, kobiet 616, chłopców 259 i dziewcząt 272. Luteran w parafii mieszkało 66, a Żydów 18, s. 246-248.

Dom rektora dosyć wygodny. Innych domów, poza organistówką, nie było. Opis zabudowań gospodarczych oraz trzech domków, gdzie mieszkali wieśniacy, plącący roczna należność proboszczowi. Na uposażenie proboszcza było pięć łanów ziemi oraz łąka nad rzeką Niechwościa leżąca, w odległości jednej mili. Były i inne łąki. Proboszcz posiadał prawo wyrębu drewna w lasach królewskich. Ponadto miał jeszcze jezioro zwane Ciepłe. Dziesięcina była zastąpiona mesznem. W ostatnim roku chrztów było 99, ślubów 7 i pogrzebów 16. Nie było innych świątyń, a jedynie kaplica we wsi Odry, s. 248-250.

Rektor kościoła Marcin Lendowski, lat 62 liczący, w parafii od 1735 r., nie mający innego beneficjum. Wikariusza, chociaż był potrzebny, nie było. Promotorem bractwa był sam proboszcz. Organista Józef Platowski, jednocześnie kantor, nauczyciel i zakrystian. Wirykusi Konstanty Libera, Jakub Jesz, Jakub Libera, J ózef Derdowicz. Uczniów było 9. Akuszerek w parafii naliczono 12 osób, ale żadna nie była zaprzysiężona i odpowiednio pouczona. Nie było przytułku, ani funduszu dla ubogich, s. 250-251.

We wsi Odry, należącej do Pawłowskiego znajdowała się kaplica pod wezwaniem Znalezienia i Podwyższenia Krzyża Świętego, w 1739 r., staraniem dziedzica Pawłowskiego od fundamentów zbudowana i do parafii Wiele włączona. Ołtarz nowy, niepodanego wezwania, z tabernakulum, ale nie przechowywano tu Najświętszego Sakramentu. Ołtarz boczny po stronie ewangelii poświęcony Matce Boskiej Jasnogórskiej, a po przeciwnej św. Barbary. Zakrystia po stronie ewangelii z paramentami liturgicznymi. Uposażenia specjalnego nie było. Cmentarz dobrze utrzymany, poświęcony, ze zezwoleniem Konsystorza Gdańskiego, przez dziekana bytowskiego, proboszcza parafii Wiele, s. 251-252.

Dekret reformacyjny dla parafii Wiele, z dnia 13 III 1766 r., s. 252-254.

Indeks parafii opisanych w tej księdze, sporządzony w czasach zaboru pruskiego, w języku niemieckim, s. 255-256. 


\section{G63b}

Księga ta jest duplikatem księgi G63a, dlatego nie zrobiono z niej repertorium.

\section{G68}

\section{A.OPIS KSIĘGI}

[1. Sygn. akt.]G68.

[2. Tytuł oryg.]Visitatio decanalis ecclesiarum in decanatu Starogardiensi anno 1780 peracta.

[3. Daty krańc.] 1779-1780.

[4. Opis zewn.] Łac. Pol. $2^{0}(34,0 \times 21,0)$. Kart foliowanych 39. Poszyt oprawiony jedynie w karton. Na nim napis: Visitatio decanalis in decanatu Starogardiensi anno 17980. Księga składa się ze składek pisanych zapewne przez proboszczów poszczególnych parafii, stąd pisany różna ręką, ale na papierze jednego formatu. Pismo czytelne, jednak atrament o różnym nasyceniu. Karty puste z odciętym prawym narożnikiem i nie foliowane.

[5. Uwagi]Pytania, na jakie musiano dać odpowiedź podczas wizytacji można poznać z protokołu sporządzonego w parafii Czersk, gdzie są odpowiedzi na poszczególne punkta, których było kilkadziesiąt.

Niektóre opisy zawierają sporo wiadomości do biografii proboszczów.

Opisy poszczególnych świątyń różnią się, co do kolejności i dokładności. Pisane różną ręką, niekiedy podpisywane przez wizytatora dziekana Bastkowskiego.

W tej wizytacji podawano więcej wiadomości o duszpasterstwie, m. inn. o przygotowywaniu do pierwszej spowiedzi oraz do małżeństwa.

\section{B. ZAWARTOŚĆ KSIĘGI}

S t a r o g a r d. Opis kościoła w mieście (civitas) Starogard w roku 1780, leżącego $\mathrm{w}$ archidiakonacie i oficjałacie pomorskim, dekanacie starogardzkim, województwie pomorskim i powiecie tczewskim. Kościół murowany, jak się przyjmuje, zbudowany przez Krzyżaków, prawa patronatu monarszego. Oceniono stan świątyni na średni, stąd wiele rzeczy wymagało naprawy, k. 2.

Spis paramentów liturgicznych. Bractwo różańcowe, posiadające dokument erekcyjny i zachowujące swoje statuty. Kaplica prywatna w Suminie, posiadłości Grąbczewskich i druga w Rokoczynie, także tych samych właścicieli. Nie było nauczyciela, a zatem pewnie nie było szkoły. Organista swoje obowiązki (może i nauczyciela) dobrze wypełniał. Na przedmieściu znajdował się przytułek dla ubogich, Alenie podano ilu było ubogich i dla ilu był fundowany, k. 2-2v. 
Parafia sąsiadowała z parafiami Kokoszkowy, Klonowo, Bobowo, Zblewo i Pinczyn. Wsie parafialne: Kudzborowo, Klincz, Ekonomia Królewska Starogardzka, zwana Amtem, miasto Starogard z przedmieściem, wieś Owidz, Barchanowy, Jabłowo, Kołcze z folwarczkiem Freda, folwarczek Płączewo, Sumin, Brzeziny, Józefowo, Rękoczyn i Nowa Wieś, k. 3.

Opis sprawowania służby Bożej i Sakramentów. Wiernych zobowiązanych do sakramentów wielkanocnych 1134 osoby. Dzieci przed przyjęciem do sakramentów, były należycie przygotowywane. Najświętszy Sakrament należycie przechowywany i Święte Postacie wymieniane latem co 8 dni, w lecie co dni 15. Wykaz dni, kiedy bywało wystawienie Najświętszego Sakramentu. Zapowiedzi małżeńskie trzykrotnie głoszone podczas nabożeństw. Oleje Święte należycie przechowywane. Nikt nie zmarł bez zaopatrzenia sakramentem chorych, k. 3-3v.

Opis uposażenie, na które składały się cztery łany ziemi, od niepamiętnych czasów nadane. Dziesięcinę pobierano w pieniądzu. Legatów nie było. Proboszcz sam nie gospodarował, ale ziemie wydzierżawił, k. 3v.

Proboszcz Jan Bastkowski, rezydujący na miejscu i wikariusz Michał Politowski. Opis nabożeństw. Proboszcz osobiście odprawia msze za parafian. Księgi metryk spisywano. Na terenie parafii nie było klasztorów, ani innych kapłanów. Stan poziomu moralnego parafii można ocenić jako należyty, k. 3v-4.

Opis kościoła filialnego w Jabłowie, znajdującego się w dobrym stanie, chociaż ubogiego, bo nie było dlań żadnych dochodów. Opis świątyni murowanej i jej wyposażenia, k. 4-4v.

Opis kościoła filialnego w Nowej Wsi, drewnianego, znajdującego się w stanie bardzo zniszczonym. Wyliczono znajdujące się tam wyposażenie, k. 4v.

K o k os z kow y ${ }^{14}$. Wieś z kościołem parafialnym w oficjałacie, archidiakonacie i województwie pomorskim, dekanacie i powiecie starogardzkim. Świątynia murowana, ale nie wiedziano wówczas przez kogo została fundowana. Prawo patronatu należało do monarchy. Stan świątyni, tak zewnętrzny, jak i wewnętrzny dobry, ale należało zreperować dach oraz drewniana wieżę. Wykaz wyposażenia w paramenty liturgiczne. Ołtarz wielki pod wezwaniem św. Barbary, boczny po stronie prawej Matki Boskiej Różańcowej, a po lewej Najświętszego Imienia Jezus. Kaplic i prebend nie było. Bractwo Różańcowe. We wsi Szpęgawsk był z dawna kościół filialny, pod wezwaniem Narodzenia Najświętszej Marii Panny, teraz w całkowitej ruinie. Miał on na uposażenie trzy łany ziemi. W tej wsi znajdowała się kaplica prywatna, posiadająca indult na sprawowanie w niej mszy. Nauczyciela Anie było, ale organista zima uczył dzieci. Przytułek dla czterech ubogich żyjących z jałmużny. Do parafii należały wsie: Kokoszkowy, Szpęgawsk, Zduny, Ciecholewy, Linowiec, Bączek Wielki, Bączek Mały, Krąg, Żabno, Pustkowie Okole, Młyn Kręcki, Pustkowie Kczewska Wola. Parafie sąsiednie to Kiszewy, Godziszewy i filia Oboźno, k.5-6v.

${ }^{14}$ Nie wiadomo kto spisywał ten protokół. Uwaga napisana osobiście przez dziekana Jana Bastkowskiego podaje, że wizytacja miła miejsce 22 I $1780 \mathrm{r}$. 
Opis sprawowania sakramentów. Chrzcielnica należycie utrzymana. Wiernych zobowiązanych do spowiedzi wielkanocnej było 464 osoby i wszyscy zadość czynili temu obowiązkowi. Dzieci do pierwszej spowiedzi należycie przygotowywano. Najświętszy Sakrament należycie przechowywany i Święte postacie odnawiane co 8 dni. Wykaz uroczystości kiedy były nabożeństwa a Wystawieniem Najświętszego Sakramentu. Do sakramentu małżeństwa wiernych należycie przygotowywano i zapowiedzi głoszono przez trzy niedziele. Oleje Święte przechowywano w specjalnych naczyniach. Nikt nie umarł bez sakramentu namaszczenia chorych, k. 6v-7.

Opis uposażenia. Cztery łany ziemi. Dokładny wykaz pobieranych powinności, zamiast dziesięciny, z poszczególnych wsi. Nie było żądnych legatów, poza zapisem 700 florenów gdańskich danych przez rodzinę Konarskich. Proboszcz dzierżawił swoją ziemię za 150 florenów niejakiemu Piotrowskiemu. Z ofiar składanych z racji pogrzebów było około 50 florenów gdańskich i szło to na remonty. Zamiast dziesięciny miał proboszcz od parafian pewną ilość ziarna pszenicy i owsa. Z ziemi należącej dawniej do kościołów filialnych w Szpęgawsku w ilości trzech łanów i Linowcu, do którego należały cztery łany, nie było żadnego dochodu. Opis stanu plebanii, która wymagała naprawy. Nie było domu dla wikariusza, a jeżeli jakiś kapłan przyjeżdżał do pomocy, mieszkał w domu proboszcza. Organista zamieszkiwał w części budynku przytułku i nie miał ani ziemi, ani ogrodu, k. $7-7 \mathrm{v}$.

Ponieważ parafia ta została jeszcze przez biskupa włocławskiego Wojciecha Gniewosza inkorporowana do klasztoru dominikanów w Tczewie, proboszczem był tamtejszy przeor, aktualnie mgr teologii Bonifacy Wilugocki, który jednak rezydował przy swoim klasztorze. Parafią administrował zakonnik Kazimierz Swarikowski. Opis nabożeństw. Na końcu uwaga odręczna dziekana Batkowskiego, że dawniejsze wizytacje, jak ta z 1761 r., wymagały aby przeor tez przyjeżdżał to tej parafii, ale tego nie przestrzegano, $\mathrm{k} .7 \mathrm{v}-8$.

K 1 o n ó w k a. Wizytacja przeprowadzona przez Jana Bastkowskiego, dziekana i prepozyta starogardzkiego, dnia 3 II 1780 r. Wieś dawniej należąca do starostwa gniewskiego, ale od niepamiętnych czasów zmieniła właściciela a aktualnie będąca własnością Jerzego z Kalkszteynów. Leżaca w dekanacie starogardzkim, oficjałacie, archidiakonacie i województwie pomorskim, powiecie starogardzkim. Świątynia murowana, w stanie dobrym, fundowana jeszcze przez Krzyżaków. Prawo patronatu należało do wspomnianego Jerzego Kalkszteyna. Stan świątyni zewnętrzny i wewnętrzny dobry, chociaż niektóre rzeczy były w stanie średnim. Organy wymagały naprawy, k. 9.

Dokładny wykaz paramentów liturgicznych, w tym także tych, które należały do bractwa Różańcowego. Cmentarz otoczony murem. Kaplic nie było. Było oratorium w Nowym Dworze, należącym do konwentu cysterskiego w Pelplinie i gdzie mieszka jeden z zakonników. Oratorium to miało indult na odprawianie nabożeństw. Nauczyciel uczył dzieci jedynie zimą. Przytułek na dwie osoby, które utrzymywały się z jałmużny. Do parafii należały wsie: Klonówka, Rywałd i Nowy Dwór oraz trzy pustkowia zwane Mosty, Marywile i Lipienki. Parafie sąsied- 
nie to Starogard, Kokoszkowy, Subkowy, Rajkowy, Pelplin i Bobowo. Chrzcielnica utrzymana czysto. Wiernych zobowiązanych do spowiedzi wielkanocnej było 420 osób. Dzieci przygotowywano do pierwszej spowiedzi dobrze. Najświętszy sakrament przechowywany dobrze, ale nie było funduszu na wieczna lampe. Ofiarami składanymi do skarbony dysponował kolator, bez udziału proboszcza czy prowizorów. Wykaz uroczystości, kiedy było wystawienie Najświętszego Sakramentu. Osoby przystępujące do sakramentu małżeństwa należycie egzaminowano i zapowiedzi głoszono w trzy niedziele. Oleje Święte przechowywano w specjalnych naczyniach. Nikt nie umarł bez zaopatrzenia sakramentem chorych, k. 9-11.

Opis uposażenia parafii w cztery łany, zapis 1000 florenów, uczyniony przez dawna kolatorke Mariannę Pawłowska na remonty świątyni, co dawało 50 florenów rocznie. Wykaz pobieranych dziesięcin. Dwie fundacje na msze lokowane na mieście Gniew i na dobrach Klonówka. Majątkiem administrował sam proboszcz. Zabudowania plebańskie bardzo zniszczone, k. 11-11v.

Proboszcz Maciej Praczkowski. Metryki spisywał. Na terenie parafii mieszkał wspomniany wyżej zakonnik cysters, ale nie mieszał się do spraw parafialnych. Zarządzeniapowizytacyjne. Dopisekdziekan,żebyodbudować domplebańskiipodpis, k. $11 \mathrm{v}-12$.

B o b o w o. Wizytacja przeprowadzona przez dziekana Bastkowskiego dnia 12 XI 1779 r. Wieś w oficjałacie, archidiakonacie pomorskim, dekanacie starogardzkim, województwie pomorskim i powiecie tczewskim, w prefekturze starogardzkiej, dawniej w starostwie gniewskim. Świątynia murowana, fundowana przez Krzyżaków, pod wezwaniem św. Wojciecha i jak się przyjmuje, konsekrowana. Prawo patronatu należało do monarchy. Świątynia wewnątrz i zewnątrz przedstawia stan średni. Ołtarz wielki pod wezwaniem Wniebowzięcia Najświętszej Marii Panny z Jej obrazem oraz boczne Matki Boskiej Różańcowej i św. Wojciecha. Opis stanu świątyni, k. 14.

Spis rzeczy ,świętych”, a więc argentariów i innych paramentów liturgicznych. Bractwo różańcowe. Nie było kaplic publicznych ani oratoriów w domach szlacheckich. Organista uczył dzieci. Przytułek w 1653 r. otrzymał przywilej od króla Jana Kazimierza i miał na utrzymanie ogród, ale praktycznie ubodzy żyją z jałmużny. Do parafii należą wsie: Bobowo, Wysoka, Smoląg i Żabienki. Podano tu zobowiązania poszczególnych wsi dla proboszcza. Dawniej wieś z Bobowa i Wysokiej dawano proboszczowi po wozie drewna, ale od 1770 r. szlachcic Adam Pałubicki, administrator dóbr starostwa gniewskiego zakazał tego wójt i odtąd mieszkańcy tych wsi drewna nie przywoża, k. 14-15.

Opis sprawowania sakramentów. Chrztu zasadniczo nie odkłada się poza okres sześciu dni. Wiernych zobowiązanych do spowiedzi wielkanocnej było około 500 osób. Do pierwszej spowiedzi oraz do sakramentu małżeństwa należycie przygotowywano. Najświętszy Sakrament przechowywany należycie. Nikt nie umarł bez sakramentów, k. 15.

Nie było żadnego dokumentu o ewentualnych darowiznach, czy zapisach na parafię. Proboszcz nieraz sam gospodaruje, nieraz wydzierżawia ziemię parafialną, której było cztery łany. Nie było prawa wolnego wyrębu drewna, czy połowu 
ryb. Kilku wieśniaków mieszkało w domkach należących do parafii i płaciło niewielki czynsz. Ponadto parafia posiadała jeden łan położony pośród pół wieśniaczych, wydzierżawionego niejakiemu Piątkowskiemu, oddającemu czynsz w wysokości 36 florenów. Ofiary z racji pogrzebów, dające około 70 do 80 florenów, szły na remonty, wino do mszy i inne potrzeby. Zamiast dziesięciny snopowej proboszcz pobierał, jak to było w Prusach Wschodnich, ale w ziarnie. Zabudowania plebańskie znajdowały się w stanie daleko posuniętej ruiny, k. $15 \mathrm{v}$.

Proboszcz Andrzej Antoni Moritz. Wikariusza nie było. Opis nabożeństw. Metryki spisywano. Na terenie parafii znajdował się konwent cysterski w Pelplinie, k. 16.

D ą b r ó w k a, wieś z kościołem filialnym.

Świątynia murowana, fundowana jeszcze przez Krzyżaków, pod wezwaniem Podwyższenia Świętego Krzyża, znajdująca się w stanie średnim. Ołtarz wielki pod wezwaniem Podwyższenia Krzyża Świętego, boczne Matki Boskiej i św. Michała. Opis stanu wewnętrznego i wyposażenia, k. 16-16v.

Wykaz rzeczy „świętych”, czyli paramentów liturgicznych. Cmentarz ogrodzony murem. Organista i nauczyciel ten sam, co w Bobowie. Przytułku nie było. Do kościoła tego należała jedynie wieś Dąbrówka, oddająca dziesięcinę zbożową w ziarnie. Ponieważ proboszcz tu nie mieszkał, w dwóch domkach należących do parafii mieszkali dzierżawcy gruntów parafialnych. Nabożeństwa odbywały się w co trzecia niedzielę, k. 16v-17.

Zarządzenie powizytacyjne i osobisty podpis dziekana Bastkowskiego, k. 17.

Z b l e w o i filia L u b i c h o w o. Wizytacja odbyła się19 X 1779 r. i została przeprowadzona przez dziekana. Zblewo, to wieś w oficjałacie i archidiakonacie pomorskim, dekanacie starogardzkim, województwie pomorskim i dystrykcie (powiecie) tczewskim, prefekturze borzechowskiej, ze świątynią wystawiona w pruski mur, wystawioną staraniem różnych dobrodziejów w 1710 r. jak twierdzą zapisy kościelne, zbudowana pod wezwaniem św. Michała Archanioła, nie konsekrowana, a jedynie poświęcona, prawa patronatu monarszego. Stan świątyni średni. Ołtarz wielki pod wezwaniem i z obrazem św. Michała, patrona kościoła, boczne zaś Najświętszego Imienia Jezus, Zwiastowania Najświętszej Marii Panny i Biczowania Pana Jezusa. Opis wyposażenia w sprzęt i stanu zewnętrznego, k. 19.

Inwentarz rzeczy ,świętych”, a więc wszelkich paramentów liturgicznych. Cmentarz wymaga dobrego ogrodzenia. Nie było prebend ani kaplic. Bractwo Matki Bożej, Najświętszego Imienia Jezus i świętego Różańca, zaprowadzone 9 IX 1732 r. Bractwa te posiadały pewne zapisy. Kaplic publicznych i oratoriów nie było. Dzieci uczył organista. Przytułku nie było. Wsie należące do parafii z podaniem oddawanych powinności: Zblewo, czyli Szteblau; Bytonia, Iwiczno, Iwickie Piece, Pustkowie Kaliska Kiszewskie; Huta Czubkowa; Borzechowo; Nierasowo z przyległościami Białachowo, Piekiełko i Nieradowko; Radziejowo; Blomfeldt z przynależnościami Kazub, Bunajek, Zamrze, Lipe, Lipska Karczma, Piełka, pustkowie Libiki; pustkowie Czarne; osada młyńska Czubek; Pustkowo Trzecho- 
wo; osada młyńska Młyńsk; pustkowie Nowa Karczma; Cisz; Łążek; Bukowiec; Krzewina. Parafie sąsiednie to Starogard, Bobowo, Pączewo, Pinczyn, k. 19- 21.

Sposób sprawowania Sakramentów. Wiernych spowiadających się na Wielkanoc około 700 osób. Dzieci do pierwszej spowiedzi należycie przygotowane. Tabernakulum, gdzie przechowywano Sanctissimum należycie utrzymane. Zapowiedzigłoszono w obydwóchświątyniach w parafii. Narzeczeni byli pouczenii przeszkodach małżeńskich. Nikt bez sakramentów nie umarł w parafii, k. 21.

Nie było zapisów na uposażenie. Rektor kościoła osobiście administruje gospodarstwem parafialnym. Miał prawo połowy ryb na swój stół i prawo wyrębu drewna w lasach. $Z$ ofiar $z$ racji pogrzebów $i$ innych okazji rocznie bywa zaledwie około 50 do 60 florenów. Zwyczajem panującym w Prusach Wschodnich dziesięcina pobierana jest $w$ ziarnie. Proboszcz miał jedynie cztery łany ziemi. Stan zabudowań plebańskich w stanie średnim. W zsadzie do napraw zabudowań zobowiązani byli parafianie, co było nawet zapisane w aktach ławniczych, ale aktualnie tego nie przestrzegano. Dom wikariusza był złączony z domem proboszcza. Spis inwentarza gospodarczego, k. 21-21v.

Proboszcz Tomasz Józef Łyszkowski, wikariusz Jan Bąkowski. Opis nabożeństw. Nie było osób prowadzących złe życie. Metryki spisywano. Nie było żadnych innych kapłanów na terenie parafii, ani klasztorów. Zarządzenia powizytacyjne, k. 21v-22.

L u b i c h o w o. Wieś z kościołem od najdawniejszych czasów filialnym parafii Zblewo. Świątynia drewniana, ostatnio staraniem aktualnego proboszcza oszalowana deskami. Zbudowana, wraz z umocnieniem w 11740 r. staraniem różnych dobroczyńców, szczególnie Kazimiera Zajewski ${ }^{15}$, ówczesnego asesora tucholskiego i dzierżawcę starostwa borzechowskiego, pod wezwaniem św. Jakuba Większego, nie konsekrowana, a jedynie poświęcona. Prawo patronatu należało do monarchy. Stan świątyni średni. Ołtarz wielki pod wezwaniem św. Józefa, boczne zaś św. Barbary i Pocieszenia Najświętszej Marii Panny. Opis stanu wewnętrznego i zewnętrznego świątyni, k. 22v.

Spis paramentów liturgicznych. Nie było żadnych kaplic, ani bractwa. Nauczyciel naznaczony przez regencję był akatolikiem. Przytułku nie było. Wsie należące do tego kościoła $\mathrm{z}$ wyliczeniem powierzchni w łanach: Lubichowo, Ossowo, Zielonagóra, czyli Grynbark, Bietowo, Ocypel, osana młyńska zwana Młynki, osada opuszczona Budy Zielonogórskie, pustkowie Krępka i Połom, Wilczebłota, Mościska, Gazda, Lipianki i folwark Stegno, k. 22v-23v.

Sposób sprawowania sakramentów. Do sakramentów Wielkanocnych było 309 osób. Dzieci do pierwszej spowiedzi uczono dobrze. Najświętszy sakrament przechowywano w należycie przyozdobionym tabernakulum. Oleje przechowywano w naczyniach odpowiednich. Wykaz uroczystości, kiedy było wystawienia Najświętszego Sakramentu, k. 23v.

Nie było żadnych zapisów na kościół. Opis gruntów plebańskich w ilości czterech łanów oraz łąki. $Z$ ofiar składanych z racji pogrzebów i nabożeństw w co

${ }^{15}$ Lekcja niepewna z powodu uszkodzenia tekstu. 
trzecią niedziel e i świeta było około 30 do 40 florenów, co szła na potrzeby świątyni. Zabudowania plebanie w sytanie średnim, ale częściowo wymagały naprawy. Organista ten co w Zbllewie, k. 23v-24.

Proboszcz i wikariusz ci sami co w Zblewie. Odprawiano tu w co trzecia niedzielę, w trzecie dni świąt i w uroczystości tu wyliczone. Metryki tu nie prowadzono, k. 24.

Zarządzenia powizytacyjne dla parafii Zblewo i kościoła filialnego w Lubichowie. Podpis własnoręczny dziekana Bastkowskiego, k. 24-24v.

C z e r s k. Jest położony w dobrach starostwa tucholskiego diecezji pomorskiej i podlega oficjałowi gdańskiemu, dekanatu starogardzkiego. Kościół drewniany, któremu podlega kościół filialny we wsi Łag, gdzie odprawiane jest nabożeństwo w co trzecią niedzielę. Po spaleniu starego kościoła, nowy został odbudowany w 1759 r. staraniem szlachcica, niejakiego Łukowitz ${ }^{16}$ oraz innych wspomagających go na czele z proboszczem i parafianami. Konsekrowany przez biskupa sufragana Cypriana Kazimierza Wolickiego w 1767 r. Prawo patronatu należało do monarchy. Świątynia wymagała naprawy. Opis stanu zewnętrznego i wewnętrznego kościoła, k. 24a-25.

Spis paramentów liturgicznych. Cmentarz należycie ogrodzony. Przy tym kościele nie było prebend ani kaplic. Bractwo św. Jana Nepomucena, ale bez własnego uposażenia. Kaplica publiczna we wsi Mokre, w dobrach Pawłowskiego, posiadająca indult na odprawianie tam nabożeństw, ale służące do tego paramenty są własnością dziedzica. Nie było szkoły, ani przytułku. Do parafii należało 12 wiosek i 30 folwarków, ale nazw tu nie wymieniono. Sąsiednie parafie to Śliwice i Wiele, zaś z sąsiedniej archidiecezji [gnieźnieńskiej] Raciąż i Nowacerkiew, k. 25-25v.

Sposób sprawowania sakramentów. Chrzcielnica o oleje utrzymane w czystości. Chrztów nie odkłada się poza 4 do 5 dni. Osób zobowiązanych do spowiedzi wielkanocnej około 1500. Dzieci do pierwszej spowiedzi odpowiednio przygotowywano. Najświętszy Sakrament przechowywano w należycie urządzonym i utrzymanym tabernakulum. Co $15 \mathrm{dni}$, a nawet częściej bywają odnawiane święte Postacie. Na wieczna lampę nie było funduszu. Wykaz świąt, kiedy było wystawienie Najświętszego Sakramentu, przy licznym udziale wiernych i procesją. Narzeczeni są pouczani o przeszkodach małżeńskich i zapowiedzi głosi się zgodnie z przepisami. Oleje święte należycie przechowywane w specjalnych naczyniach mosiężnych. Nikt nie zmarł bez sakramentów, k. 26.

Uposażenie parafii. Należało do niej cztery łany ziemi. Innych zapisów nie było. Gospodarstwo prowadzi sam proboszcz. Daje to rocznie około 100 florenów. Zabudowania plebańskie w stanie średnim. Sam proboszcz był odpowiedzialny za remonty. Nie było żądnego domu dla wikariusza, ani dla niego uposażenia, k. 26v.

\footnotetext{
${ }^{16}$ Lekcja niepewna
} 
Proboszcz Szymon Plutowski, nie posiadający innego beneficjum. Wikariusz niepodanego imienia Dolatowski. Opis sprawowanych nabożeństw. Metryki spisywano. Nie było na terenie parafii innych kapłanów, czy klasztorów, k.27.

Ł ą g. Wieś z kościołem filialnym w parafii Czersk. Świątynia zbudowana staraniem mieszkańców wsi, którzy mieli od dawna przywilej utrzymywania przy niej kapłana dla sprawowania nabożeństw. Przy kościele tym chowali się zmarli z wsi i folwarków doń należących. Stan świątyni średni. Cmentarz ogrodzony. Spis paramentów liturgicznych. Na końcu uwaga dziekana Bastkowskiego, że przy tym kościele był stary proboszcz sparaliżowany, zaś zarządca młody, bardziej dba o siebie, niż o chwałę Pana Jezusa, k. 27v.

$\mathrm{S}$ t a r a K i s z e w a. Wizytacja odbyta przez dziekana Bastkowskiego dnia 23 X 1779 r. Wieś królewska. Swiątynia drewniana, ale dzwonnica (może wieża) z pruskiego muru. Fundowana w 1741 r. staraniem Stanisława i Katarzyny z Iwanickich Skórzewskich, pod wezwaniem św. Marcina, a także św. Walenty, kapłan męczennik. Świątynia składała się z prezbiterium i nawy. Konsekrowana przez biskupa Fabiana Franciszka Pląskowskiego, sufragana chełmińskiego 11 XI 1759 r. Prawo patronatu należało do monarchy. Opis stanu świątyni. Dzwonnica wymagała pilnej naprawy, k. 28.

Spis paramentów liturgicznych. Cmentarz ogrodzony. Żadnych prebend nie było. Kaplica pod wezwaniem św. Barbary, stojąca w miejscu, gdzie dawniej był kościół, drewniana, z cmentarzem wokół, którego ogrodzenie wymagało naprawy. Msze sprawowane w święto patronki. Żadnego funduszu kaplica ta nie posiadała. Nie było bractwa, ale w roku przyszłym ma powstać bractwo Szkaplerza. Organista uczył dzieci. Przytułku nie było. Parafien sąsiednie to Zblewo, Kogutkowy, Niedomowo, Wiele i Czersk. Wsie parafialne: tara Kiszewa, Zamkowa Kiszewa, Nowa Kiszewa, Bartoszówlas, Konarzyny, Olpuch, Bartel, Studzienice, Kuta, Maliki Górne, Strzelki, Bożepole, Chwarzno, Chwarzienko, Foshuta, Szuflarze, Bukowiec Stary Bukowiec Nowy, folwark Bukowiecki, pustkowie Bukowieckie, Pałubie, Ruda, Cięgardno, Barłogi, Gołuń, Wygonin, Nierybno, DStruga, Żubrek, Ciehorka, Sztecka, Libiki, Uroza, Nowy Folwark, Tuszdus zwany Turowo, ale bez miszkańców, oraz Babie, także nie zamieszkałe, k. 28-29.

Sposób sprawowania sakramentów. Chrzcielnica sprawiona w 1762 r., Ambona z 1764 r. Piscyna pod ołtarzem wielkim. Oleje corocznie zmieniane. Chrzest sprawowany jaknajszybciej po urodzeniu i w świątyni, chyba w wypadku konieczności w domu. Do Komunii Wielkanocnej było 802 osoby. Dzieci należycie przygotowywane do pierwszej spowiedzi. Najświętszy Sakrament przechowywany w tabernakulum ładnie przyozdobionym i odnawiany co 15 dni. Lampa wieczna zazwyczaj się paliła. Wykaz świat z Wystawieniem Najświętszego Sakramentu. Sakrament małżeństwa udzielany po pouczeniu i po zapowiedziach. Oleje przechowywane w naczyniach mosiężnych. Nikt nie umarł bez sakramentów, k. $29-29 \mathrm{v}$.

Uposażenie w cztery łany ziemi od najdawniejszych czasów. Dziesięcina była pobierana w ziarnie. Pobożnych zapisów nie było. Rektor kościoła sam prowadzi 
gospodarstwo. Ofiary jakie zbierano szły na potrzeby kościoła. Zabudowania plebańskie w stanie średnim i naprawiane przez proboszcza. Opis uposażenia z czasów krzyżackich i szkód wyrządzanych podczas wojen szwedzkich, k. 29v.

Proboszcz Andrzeju Schulz. Wikariusz Jan Tendycki. Porządek nabożeństw. Metryki spisywano. Innych kapłanów, ani klasztorów nie było. Zarządzenia z poprzedniej wizytacji Trochowskiego z 1765 r. aktualny proboszcz wypełniał. Protokół podpisał osobiście dziekan Bastkowski, k.29v-30.

$\mathrm{S} \mathrm{t}$ a $\mathrm{r}$ e $\mathrm{P}$ o 1 a s z k i. Wieś otrzymała prawo magdeburskie od Krzyżaków w 1420 r. Z przywileju króla polskiego Zygmunta III z 1555 (W 1555 r. królem był Zygmunt August) stała się wsią dziedziczną i aktualnie w posiadaniu Michała i Ludwiki z Czapskich małżonków Skórzewskich, ale jako wsi królewskiej. Kościół $\mathrm{w}$ tej wsi, fundowany jako parafialny, teraz z powodu małego uposażenia, złączony jako filialny z parafia w Kiszewie. Świątynia murowana, w 1752 r. staraniem Stanisława i Katarzyny z Iwanickich Skórzewskich, starostów kiszewskich, zbudowana pod wezwaniem św. Mikołaja. Prawo patronaty wg przywileju Krzyżaków należało do posiadaczy wsi, teraz nie ma dokładnego określenia. Pewnie należy do monarchy. Świątynia w dobrym stanie, k. 30v.

Spis paramentów liturgicznych. Cmentarz ogrodzony murem. Bractwa, ani oratooriów, czy też przytułku, nie było. Organista ten co w Kiszewie. Wsie parafialne: Stare Polaszki, Nowe Polaszki, Wilcze Błoto, Sztecha. Parafie sąsiednie to Kiszewy, Pogutkowy i Garczyn, k. 30v-31.

Sposób sprawowania sakramentów. Chrzcielnicy nie było, bo chrztu udzielano w parafii. Chrztu nie odkładano i jedynie w razie konieczności chrzczono w domu. Oleje odnawiano corocznie. Wiernych do spowiedzi wielkanocnej około 80 osób. Dzieci do pierwszej spowiedzi należycie uczono. Najświętszy Sakrament przechowywano i odnawiano w co trzecia niedzielę. Lampa nie paliła się. Wykaz dni, gdy było wystawienie Najświętszego Sakramentu. Zapowiedzi małżeńskie głoszono w obydwóch kościołach, a narzeczonych pouczano o przeszkodach Nikt nie zmarł bez sakramentów, k. 31 .

Uposażenie, jeszcze z czasów krzyżackich pochodzące, stanowiły cztery łany ziemi, jak to jest w przywileju z 1420 r., ale od czasów niepamiętnych kościół jest w posiadaniu jednego łana. Ostatnio toczono spór i proces o odzyskanie całości. Dziesięcinę pobierano w zbożu. Zapisów nie było żadnych. Ziemie proboszcz wydzierżawił i corocznie odnawiał kontrakt. Otrzymywał rocznie 24 floreny. Ofiary składane do skarbony i z pogrzebów nawet nie wystarczają na koszty związane z nabożeństwami. Organista ten co w Kiszewie, ale miał także tu pewne wynagrodzenie, k.31-31v.

Proboszcz i wikariusz ci sami co w Kiszewie i tam rezydują. Tu odprawia się w co trzecia niedzielę i takie SA nabożeństwa, jak w Kiszewie. Metryki spisywano. W zarządzeniu przypomniano, żeby odzyskać uposażenie. Podpisał własnoręcznie dziekan Bastkowski, k. 31v. 
P o g u t k o w y $\mathrm{y}^{17}$, czyli $\mathrm{Now}$ a $\mathrm{D}$ ą b r ow a. Wieś opactwa pelplińskiego. Świątynia z solidnego muru pod wezwanie. Św. Apostołów Piotra i Pawła, wystawiona staraniem Tomasza Franciszka Czapskiego, koadiutora biskupa chełmińskiego i opata pelplińskiego ${ }^{18} \mathrm{w} 1715$ r., konsekrowana natomiast w $1767 \mathrm{r}$. przez Fabiana Franciszka Pląskowskiego ${ }^{19}$, sufragana i oficjała generalnego chełmińskiego. Prawo patronatu zawsze należało do opata z Pelplina. Ołtarz wielki, pod wezwaniem patronów, odnowiony w 1765 r., i na nim tabernakulum, dobrze urządzone, gdzie przechowywano Najświętszy Sakrament. Lampa paliła się zawsze. Oleje przechowywano należycie i zmieniano każdego roku. Relikwie w tym kościele się znajdujące, przechowywano należycie. Było bractwo Aniołów Stróżów, założone w 1634 r., mające przywileje odpustowe na wyliczone tu dni. Ołtarzy bocznych było pięć. W kaplicy Wniebowzięcia Najświętszej Marii Panny, W kaplicy Aniołów Stróżów, odbudowany i złocony w 1768 r., W kaplicy św. Jerzego, przy ścianie pod wezwaniem Świętego Krzyża i także przy ścianie, nowy pod wezwaniem św. Jana Nepomucena. W 1770 r. sprawiono nowa ambonę, w roku następnym sprawiono ambonę. Dalej opis stanu wewnętrznego i zewnętrznego świątyni i jej otoczenia, k. 32-32v.

Uposażenie kościoła stanowiły dwa łany ziemi, znajdujące się we wsi Kosmin i w we wsi Kleszczewo. Sposób sprawowania nabożeństw. Oratoria prywatne, posiadające wszystko do sprawowania nabożeństw dwa. Jedno w Pogutkowach, dobrach opata pelplińskiego, drugie w folwarku Malary, także go opactwa pelplińskiego należącego. Proboszczem był zakonnik cysterski Anzelm Powalski. Dom proboszczowski zbudował poprzedni proboszcz, zakonnik Aleksander Białochowski. Opis pozostałych zabudowań gospodarczych. Przytułek o dwóch izbach w domu zbudowanym na placu po śmierci dotychczasowej właścicielki Wymłowe $\mathrm{j}^{20}$, ale bez własnego uposażenia. Dom dla organisty $\mathrm{w}$ pobliżu świątyni. Zapisów żadnych nie było, jedynie Hieronim Stefan Turno, opat z Pelplina, dał jeden domek we wsi Kosmin, z którego czynsz szedł na lampę palącą się przed Sanktissimum. Organista Andrzej Myszkier, uczący niewielka grupę dzieci. Wyznaczeni zostali ostatnimi casy nauczyciele w innych sąsiednich wioskach. Witrykusami byli Józef Baszkiewicz i Maciej Niedrzwicki, obydwaj ze wsi Pagodki. Na uposażenie proboszcza było osiem łanów, w Kogutkach i w Kleszczewie. Wsie parafialne: Kleszczewo, Jaroszewy, Kosmin, Więckowy, Głodowo, Jądrowy, Pagodki, Kobyle, Czernikowy, Malary, Wałdówko, Jezierze, Ryle, Tomaszewo, Zawada, Bukowiec, Brzęczek, Milonki, Szczepanowo, Liszewko, Deka, k. 32v-33.

Inwentarz paramentów liturgicznych, dosyć ubogi, k. 32v.

Dekret reformacyjny z wizytacji Trochowskiego z 1765 r. Podpis dziekana Bastkowskiego, k. 34.

P i n c z y n. Wizytacja dnia 15 XII 1779 r. przeprowadzona przez dziekana Starogardzkiego Jana Bastkowskiego. Wieś w archidiakonacie, oficjałacie i woje-

\footnotetext{
${ }^{17}$ Nazwę tej wsi pisano różnie: Pogutkowy, Pogutki, Pagotki.

${ }^{18}$ Biogram zob. Nitecki, Kapłani kościoła w Polsce, k. 62.

${ }^{19}$ Biogram tego biskupa zob. Nitecki, Kapłani kościoła w Polsce, k. 352.

${ }^{20}$ Lekcja niepewna z powodu uszkodzonego tekstu.
} 
wództwie pomorskim, starostwie kiszewskim, powiecie tczewskim. Kościół drewniany, w 1720 r. wystawiony staraniem parafian, innych dobrodziejów, szczególnie zaś Stanisława i Katarzyny Skórzewskich, pod wezwaniem św. Katarzyny, konsekrowany w 1759 r. przez Fabiana Franciszka Pląskowskiego, sufragana chełmińskiego. Prawo patronatu należało do monarchy. Stan świątyni średni i jej opis zewnętrzny i wewnętrzny. Sześć ołtarzy. Wielki pod wezwaniem św. Katarzyny, zaś boczne Opatrzności Bożej, św. Onufrego, Niepokalanego Poczęcia Najświętszej Marii Panny, .św. Józefa i św. Rocha. Wszystkie należycie ozdobione i wyzłocone, k. 35-36.

Spis paramentów liturgicznych i innych rzeczy kościelnych. Cmentarz należycie ogrodzony. Nie było prebend, ani kaplic przy tej świątyni. Bractwo św. Józefa założone w 1737 r. mające przywilej odpustowy. Nie było na terenie parafii kaplic publicznych, ani oratoriów prywatnych. Jeżeli była potrzeba, dzieci uczył organista. Przytułku dla ubogich nie było. Wsie parafialne: Pinczyn, Pustkowie Pinczynem, Przemyśle, Salin, Samlinek, Piszenica, Bukowiec, Sucimin, Suciminek, Góra, Nowy Dworzec, Borowa Karczma, Pałubinek. Parafie sąsiednie: Zblewo i Pogutkowy. Niektóre wsie zaznaczono jako opuszczone, k. 36-37.

Sposób sprawowania sakramentów. Chrzcielnica stojąca obok ołtarza św. Józefa. Oleje święte z ostatniego roku, stare zostały spalone. Chrztu nie odkłada się. Osób zobowiązanych do spowiedzi było 260. Dzieci do spowiedzi należycie przygotowywane. Najświętszy Sakrament przechowywany w należycie urządzonym tabernakulum i odnawiany w ciaggu 15 dni. Wyliczono święta obchodzone z wystawieniem Najświętszego Sakramentu i procesji. Pouczano o przeszkodach małżeńskich i zapowiedzi głoszono. Oleje święte przechowywano w naczyniach mosiężnych. Sakramentu chorych udzielano i nikt nie zmarł bez zaopatrzenia, k. 37-37v.

Uposażenie kościoła składało się z czterech łanów lichej ziemi oraz łąki. Aktualnie zabroniono, dawniej przysługującego, prawa wyrębu drewna. $Z$ trzech stawów, pewnie dawniej do parafii należących, dwa zatrzymali sobie miejscowi właściciele. Wykaz mesznego, jakie tradycyjnie było oddawane z wiosek: Pinczyn, Salin, Góra, Pszenica, Sucimin, Kolonia Pinczynek, Sadlinek, Salin, Nowy Dworzec, Borowska Karczma. Pewne świadczenia należały się także z młynów Bukowiec i Pszenica. Dawniejsza wielkość tych świadczeń była zapisana w przechowywanym w parafii protokole wizytacyjnym Jana Kazimierza Jugowskiego. Pobożnych zapisów nie było. Rektor kościoła osobiście administrował gospodarstwem. Zabudowania plebańskie wymagały naprawy, do czego z dawniejszego prawa byli zobowiązani parafianie, k. $37 \mathrm{v}-38 \mathrm{v}$.

Proboszcz Michał Józef Lubaszewski, rezydujący na miejscu. Wikariusza nie było. Metryki spisywano. Innych kapłanów, czy klasztorów na terenie parafii nie było. Przypomniano dawne zarządzenia powizytacyjne z 1768 r. z wizytacji Bartłomieja Franciszka Trochowskiego. Na zakończenie wizytator Bastkowski, podpisując ten protokół zapisał, że proboszcz wypełnia to, ci do niego należy, ale $\mathrm{z}$ niewiadomych mu powodów nie żyje w zgodzie z kolatorem, k. 38v-39. 


\section{G69}

\section{A. OPIS KSIĘGI}

[1. Sygn. Akt.] G69.

[2. Tytuł oryg.] Visitatio Generalis Ecclesiarum Decanatuum Butovien[sis] Leoburgen[sis] ac Mirachoviensis ex mandato illustrissimi Excellen[tissi[mi] D[omi]ni Domini Josephi Rybinski Ep[isco]pi loci ordinarii Vladidlaviensis ac Pomeraniae, per Perillustrem Admodum Reverendum JJ Gręca CC decanum praepositum Pucensem, praedictorum dacanatuum ecclesiarum visitatorem generalem deputatum expedita Anno 1780.

[3. Daty krańc.] 1780.

[4. Opis zewn.] Łac., Pol. $(33,7 \times 21 \mathrm{~cm})$. Karta nie foliowana na początku z pieczęcią Archiwum Diecezjalnego w Pelplinie. Tabele zestawiające dane poszczególnych parafii, zawierające wiele danych, ale bardzo zniszczone i wymagające zabezpieczenia. Stron paginowanych cyfrą rzymską II, kart foliowanych cyframi arabskimi 255. Pismo czytelne i ładne. Stan zachowania księgi dobry, ale przy oprawie obcięto nieco tekstu. Niektóre karty załamane. Pismo kilku rąk. Najpierw notariusza Jana, , proboszcza z Ugoszcza oraz proboszczów wizytowanych parafii, którzy dawali odpowiedzi na pytania wizytacyjne. Dekrety reformacyjne pisał sam wizytator J. Gręca. Karty puste: 3v, 30v, 52v, 59v, 71v, 77v, 86v, 87v, 95v, $102^{\mathrm{a}} \mathrm{v} ; 103 \mathrm{v}, 121 \mathrm{v}, 136 \mathrm{v}, 149,156 \mathrm{v}, 161 \mathrm{v}, 192 \mathrm{v}, 233 \mathrm{v}, 249 \mathrm{v}$.

[5. Uwagi] Protokóły wizytacyjne nie zachowują chronologii, czyli księga sporządzona po zakończeniu wizytacji.

Dekrety reformacyjne, bardzo zwięzłe, sporządzone i spisane osobiście przez samego wizytatora.

Szczegółowe dane o miejscowościach parafialnych i parafianach zamieszczają tabele sporządzane dla każdej parafii.

Wizytator podawał położenie parafii przez wyliczanie parafii sąsiadujących, a także odległości od Włocławka, Wolborza i innych miejscowości ważnych dla administracji diecezjalnej.

Jest bardzo wiele wiadomości do biografii ówczesnego duchowieństwa. Była to właściwie wizytacje wewnętrzna, ponieważ pytano także o pracę i zachowanie duchowieństwa. Wizytator opisywał także, w jaki sposób proboszcz spełnia swoje powinności administracyjne, a także, czy wypełnił punkty z poprzednich wizytacji. Każda wizytacja jest zakończono bardzo dokładnymi odpowiedziami na pytania jej dotyczące, zapewne sformułowanymi przez biskupa. Pewnie były one dane razem z dekretem upoważniającym wizytatora do przeprowadzenia wizytacji, następnie przekazywane zainteresowanym proboszczom. Tych pytań było ponad trzysta. Odpowiedzi pisali sami proboszczowie. Stanowią one największe źródło wiadomości. Chcąc ich treść przedstawić, należałoby je dokładnie przepisać, stąd podano jedynie karty, na których są spisane.. 


\section{B. ZAWARTOŚĆ KSIĘGI}

Karta wewnętrzna okładki z pieczęcią okragłą z napisem Archiwum Diecezji Chełmińskiej, Pelplin, bez numeracji.

Strona tytułowa $\mathrm{z}$ tytułem $\mathrm{w}$ języku łacińskim, oraz z uwagą osobiście napisana przez biskupa chełmińskiego, [Anastazego] Sedlaga w 1842 r., jak wyżej, s. I.

Indeks parafii z podaniem kar, na których są spisane protokoły wizytacyjne, s. II.

\section{[Dekanat bytows ki]}

Opis dekanatu bytowskiego ujęty w 35 punktach, s. k. 1-3.

Zestawienie tabelaryczne dekanatu poprzedzone krótkim jednostronicowym opisem, zawierające kolejno nazwę parafii, kościoły filialne, kościoły, przy których nie prowadzono duszpasterstwa, kaplice i oratoria publiczne, położenie administracyjne, odległość od kościoła siedziby dekanatu, imiona i nazwiska proboszcza i wikariusza, liczna zakonników, krótka ocena postawy proboszcza i wikariuszy, k. $2^{21}$

B y tó w. Wizytacja generalna kościoła prepozyturalnego w Bytowie, przeprowadzona dnia 9 XI 1780 r. Kościół prepozyturalny,pod wezwaniem św. Katarzyny, prawa patronatu monarszego, aktualnie króla pruskiego. Opis położenia geograficznego. Stan kościoła średni. Jeżeli zakrystia murowana, to zapewne i cała świątynia. Wieża wymagała naprawy. Dzwonnica złączona ze świątynią, a więc rolę dzwonnicy zapewne pełniła ta wspomniana wieża. Jeden dzwon. Cmentarz nie był należycie ogrodzony. Kostnicy nie było. Dzieci zmarłe przed chrztem chowano w polu, k. 4.

Wyposażenie w paramenty liturgiczne. Parafia posiadała pieczęć z wyobrażeniem św. Katarzyny. Konieczne meble w świątyni się znajdowały. Nowe organy. Ołtarz wielki św. Katarzyny, boczne Ukrzyżowanego i św. Jana Nepomucena. Obrazów łaskami słynących nie było. Znajdowały się tu jakieś relikwie, ale bez dokumentów autentyczności. Odpusty na święto św. Katarzyny, św. Jana Chrzciciela. Nie było prebend, bractw, ani kaplic publicznych, czy prywatnych. Ale były trzy kościoły filialne, niżej omówione. Na terenie parafii mieszkali liczni akatolicy, którzy posiadali kaplice publiczne, dwie w Bytowie jedną we wsi Tuchom, a przy nich swoje cmentarze. Mieszkali także w Bytowie Żydzi, posiadający własną szkołę. Nie było żadnej drukarni. Szkoły nie było, jedynie organista uczył w porze zimowej. Szkoła niemiecka przy kościele filialnym w Niezabyszewie. Przytułku dla ubogich nie było, k. 4-6.

Wykaz tabelaryczny, dokładny, według miejscowości parafialnych, k. $5^{22}$.

${ }^{21}$ Ta karta $\mathrm{z}$ tabelą, podobnie zresztą jak i inne tabele w tej księdze, podwójnego wymiaru, zapewne wklejone po sporządzeniu całej księgi, ale przed sporządzeniem numeracji kart, stąd noszą numer bieżący.

${ }^{22}$ Wykaz tabelaryczny dotyczący stanu parafii składający si z dwóch kart, z których druga została wszyta. Stan tabeli znacznie zniszczony. Tabele te dotyczące parafii zawierały następujące 
Opis sposobu sprawowania sakramentów, k. 6-6v.

Proboszcz Franciszek Węsierski i dosyć szczegółowe dane o jego osobie oraz zachowaniu, wikariusz Michał Grabowski, organista Jakub Maszloch, k. 7-7v.

Klasztorów nie było. Krótka charakterystyka parafian, k.7v.

Opis stanu beneficjum i wykaz dochodów i rozchodów, oraz inwentarza kościoła parafialnego i gospodarstwa plebańskiego, k. $7 \mathrm{v}-8 \mathrm{v}$.

$\mathrm{N}$ i e z a y s z e w o. Kościół filialny, wizytowany łącznie z parafią w Bytowie. Kościół drewniany, pod wezwaniem św. Mikołaja. Uposażenie niewielkie. Wykaz inwentarza kościoła i plebanii, k. 8v-9.

D ą b r ó w k a. Kościół filialny, drewniany i stary, ale niedawno naprawiony. Wizytacja łącznie z Bytowem. Nie było tu sprawowanych nabożeństw, k. 9-9v.

T u c h o m i e ${ }^{23}$. Kościół filialny, pod wezwaniem św. Michała Archanioła, drewniany, dawniej parafialny. Opis, dosyć dokładny, kościoła i inwentarza, k. $9 \mathrm{v}-10$.

Protokół powizytacyjny, podpisany przez wizytatora J. Gręca i notariusza J. Postelle, Podpis własnoręczny pod protokołem wizytatora i notariusza, z pieczęcią wyciśniętą w czerwonym laku, k. 10-10v²4.

Dekret reformacyjny dla kościoła prepozyturalnego w Byszewie i kościołów filialnych Niezabyszewie, Tuchomiu i Dąbrówce, napisany i podpisany przez wizytatora Gręca, k. 11-11v.

Odpowiedzi według pytań, na temat stanu parafii Bytów ${ }^{25}$, zawierająca 338 pozycji, k. 12-16.

Odpowiedzi na pytania o stanie kościoła filialnego w Niezabyszewie, ujęte w 320 pytań $^{26}$, k. $16-18$ v.

Krótka charakterystyka kościoła w Dąbrówce, k. 18v-19.

Odpowiedzi według pytań o kościele filialnym w Tuchomiu ujęte w 338 pytań, $\mathrm{k} 19-21 \mathrm{v}^{27}$.

dane: Nazwa miejscowości parafialnej, odległość od kościoła parafialnego, właściciel wsi, w jaki, państwie buła położona, W jakim województwie i powiecie, liczna katolików ogółem, liczba przystępujących do sakramentów świętych, liczba akatolików i liczba Żydów. Należy na tym miejscu stwierdzić, że tabele w tej księdze wymagają odpowiedniego zabezpieczenia, ponieważ od częstego korzystania, są znacznie uszkodzone,

${ }^{23}$ Używano tu nazwy Wielkie Tuchomie.

${ }^{24}$ Zawsze w protokole powizytacyjnym wizytator powoływał się na otrzymana delegację do przeprowadzenia wizytacji generalnej, otrzymana dnia 20 V 1780 r. od biskupa włocławskiego Józefa Rybińskiego.

${ }^{25}$ Są to bardzo szczegółowe pytania. Odpowiedzi częściowo w języku łacińskim, częściowo w języku polskim. Dużo wiadomości o proboszczu, jego pracy w parafii i życiu osobistym..

${ }^{26}$ Numeracja pytań albo pomylona, albo celowo opuszczone pewne kwestie, bo po numerze 300 następuje numer 305.

${ }^{27}$ Nie podano, kto te odpowiedzi sporządził, ale spodziewać się można, że sam proboszcz. 
U g o s z c z. Wizytacja dnia 6 XI 1780 r. Kościół parafialny w Ugoszczu, po niemiecku Berensdorf, którego kolatorem był monarcha pruski, drewniany, zbudowany z ofiar parafian w 1736 r. Opis położenia geograficznego parafii. Świątynia w stanie dobrym. Wykaz paramentów liturgicznych i opis ołtarzy. Przywileje odpustowe na święta św. Marii Magdaleny i św. Barbary. Bractwo Szkaplerza. Nie było żadnej kaplicy. Jednak akatolicy posiadali dwa oratoria, we wsi Borzytuchom i Somoniny, k. 22-24.

Wykaz tabelaryczny stanu parafii wg miejscowości parafialnych, k. $23^{28}$.

Opis sprawowania sakramentów, k. 24-25.

Proboszcz Jan Postell. Dosyć dokładne dane biograficzne. Proboszcz zatrudnia wikariusza, nazwiskiem Kempski, który odprawia w co czwartąniedzielę w kościele filialnym w Studzienicach. O)organista i zakrystian Paeł Borowka. Klasztorów nie było. Krótka charakterystyka parafian, k. 25-26.

Opis stanu beneficjum parafialnego. Spis inwentarza kościoła parafialnego we wsi Ugoszcz oraz gospodarstwa plebańskiego, k. 27-27v

S t u d z i e n i c e. Kościół filialny, drewniany, pod wezwaniem Świętej Trójcy. Opis świątyni, jej stanu, wyposażenia i ołtarzy. Odpusty z okazji święta Świętej Trójcy, Matki Boskiej Różańcowej i innych świąt maryjnych z racji bractwa Różańcowego. Opis uposażenia kościoła i jego inwentarz, k. 27v-28v.

B o r z y t u c h o m. Świątynia filialna, drewniana, pod wezwaniem świętych Piotra i Pawła. Odpusty z okazji święta Zwiastowania Najświętszej Marii Panny i św. Jana Ewangelisty. Bractwa żadnego nie było. Opis beneficjum i inwentarz kościoła, k.28v-29v.

K o t k o w o. Mała świątynia, nie posiadająca swego wezwania, zbudowana w 1764 r. przez Michała Kempskiego, ówczesnego proboszcza w Ugoszczu. Nie sprawowano tu nabożeństw. Wykaz skromnego wyposażenia, k. 29v.

Dekret reformacyjny dla kościoła parafialnego i świątyń filialnych, z własnoręcznym podpisem wizytatora, k. 30 .

Protokół wizytacyjny podpisany przez wizytatora J. Gręca i notariusza J. Postella, k. dnia 6 XI 1780 r., k. 29v-31.

Odpowiedzi na szczegółowe pytania odnoszące się do wizytowanego kościoła parafialnego i filialnych, podpisane przez proboszcza Jana Postylla, k. 32-39.

P a r c h o w o. Wizytacja 15 XI 1780 r. Kościół parafialny we wsi Parchowo, pod wezwaniem św. Mikołaja, prawa patronatu króla pruskiego, drewniany. Opis położenia geograficznego parafii. Krótki opis stanu świątyni i jej wyposażenia, ołtarzy i obrazów Bractwo Bożej Opatrzności. Kaplic żadnych nie było. Akatolicy także żadnego zboru nie posiadali i chowali się na miejscu wyznaczonym na cmentarzu parafialnym, chociaż chowali się też na swoim cmentarzu we wsi Pomysk. Żydzi, jacy mieszkali na terenie parafii swoje nabożeństwa odprawiali

\footnotetext{
${ }^{28}$ Jest to złożona karta ze wszytym dodatkiem.
} 
w domu prywatnym we wsi Hosznica i tam mieli swoje miejsce pochówku. W szkole przy kościele uczył organista Antoni Trepkowski. Uczniów w zimie było 8 lub 9. Przytułku nie było, a ubodzy mieszkali po wsizck, k. 40-40v.

Wykaz tabelaryczny stanu parafii wg miejscowości, k. 41.

Opis sprawowania sakramentów, k. 40v-42v.

Proboszcz Ignacy Rogowski. Wikariusza nie było. Organista Antoni Trejkowski. Zakonników żadnych nie było, k. 42v-43v.

Stan beneficjum parafialnego z wyliczeniem dochodów i rozchodów. Spis inwentarza świątyni oraz gospodarstwa proboszczowskiego. k. 43v-44v.

Protokół zakończony przypomnieniem, że wizytacja ta odbyła się na mocy dekretu biskupa Rybińskiego z dnia 20 V 1780 r., danego niżej podpisanemu wizytatorowi. Własnoręczny podpis wizytatora i notariusza, którym był proboszcz z Ugoszcza, Jan Postella. Pieczęć, k. 44v-45.

Dekret reformacyjny dla parafii w Parchowie, z dnia 15 XI 1780 r., podpisany własnoręcznie przez wizytatora J. Gręca, k. 46.

Odpowiedzi na szczegółowe pytania odnoszące się do parafii, ujęte w 338 punktów. Odpowiedzi te spisał własnoręcznie i podpisał ks. Ignacy Rogowski, k. 47-52.

S u 1 ę c z y n o. Wizytacja 17 XI 1780 r. Kościół parafialny w tej wsi, drewniany, prawa patronatu Józefa Laszewskiego, pod wezwaniem Świętej Trójcy. Opis położenia parafii. Krótki opis stanu świątyni, jej wyposażenia. Bractwo Różańcowe. Nie było żądnych kaplic. Byli akatolicy, nie było Żydów. W szkole parafialnej uczył organista. Przytułku nie było, k. 63-55.

Wykaz tabelaryczny stanu parafii ujęty wg miejscowości parafialnych, k. 54.

Sposób sprawowania sakramentów, k. 55-56.

Proboszcz Jan Malotka. Organistą i zakrystianem jednocześnie był Jakub Wróblewski, k. 56-57.

Stan beneficjum parafialnego i spis inwentarza kościoła parafialnego oraz inwentarza gospodarstwa proboszcza, k. 57-58v.

Protokół podpisany przez wizytatora J. Gręca i notariusza J. Postella, 17 XI 1780 r. Pieczęć, k. 58v.

Dekret reformacyjny z 17 XI 1780 r., podpisany przez wizytatora J. Gręca i własnoręcznie podpisany, k. 59.

Odpowiedzi na pytania dotyczące parafii, spisane osobiście przez proboszcza z Sulęczyna, Jana Malotka, k. 60-65.

W i e 1 e. Wizytacja w dniu 23 X 1780 r. Świątynia parafialna we wsi Wiele, drewniana, pod wezwaniem św. Mikołaja, prawa patronatu monarszego. Opis położenia parafii, stan świątyni i jej wyposażenia w paramenty liturgiczne. Opis ołtarzy. Żadnych kaplic nie było. Bractwo św. Anny, św. Józefa i św. Antoniego Padewskiego. Kaplica publiczna we wsi Odry i jej krótki opis. W szkole parafialnej uczył organista Antoni Szefler. Przytułku nie było, k. 66-68.

Wykaz tabelaryczny parafii, k.67.

Opis sprawowania sakramentów, k. 68-68v. 
Proboszcz Jan Netzel. Wikariusz Krzysztof Worochowski, organista Antoni Szefler. Żadnych innych kapłanów, ani zakonników nie było. Krótka charakterystyka parafian, k. $68 \mathrm{v}-69 \mathrm{v}$.

Opis stanu beneficjum i jego dochodów. Spis inwentarza gospodarstwa plebańskiego, k. 69v-70v.

Dekret reformacyjny dla kościoła parafialnego we wsi Wiele, z dnia $23 \mathrm{X}$ 1780 r., podpisany przez wizytatora. Gręca, k. 71.

Protokół podpisany przez wizytatora J. Gręca i notariusza J. Postella, dnia 23 X 1780 r. Pieczęć, k. 72.

Odpowiedzi na pytania dotyczące parafii, spisane osobiście przez proboszcza z parafii Wiele, Jana Netzel, k. 73-77.

B r u s y. Wizytacja odbyta 27 X 1780 r. Kościół parafialny, drewniany, pod wezwaniem Wszystkich Świętych, zbudowany przez proboszcza miejscowego Piotra Niezorawskiego w 1767 r., konsekrowany przez sufragana pomorskiego Cypriana Wolickiego w 1769 r. Prawo patronatu należało do monarchy pruskiego. Opis położenia parafii, stanu świątyni i jej wyposażenia w paramenty liturgiczne i opis ołtarzy. Bractwo Szkaplerza. Nie było kaplic publicznych. Kaplica prywatne we wsi Wielkie Chełmy, w posiadłości [Michała] de Lewaldt Jezierskiego, ale aktualnie nie było tam kapelana. Poprzednio był kapelan Marin Kobielski z zakonu augustianów eremitów. Żydów nie było. Nie było szkoły publicznej. Organista Franciszek Płatowski prywatnie uczył dzieci. Przytułek przy kościele drewnianym, dla czterech podopiecznych, ale prepozyta tego kościółka nie było. Aktualnie były tam dwie pary małżeńskie i jeszcze jedna osoba. Na utrzymanie, z uposażenia 40 florenów, tym, jak i innym ubogim włóczącym się, to co konieczne, dawał proboszcz, k. 79-81.

Wykaz tabelaryczny parafii k. $80^{29}$.

Opis sprawowania sakramentów, k. 81-82.

Proboszcz Andrzej Łysakowski. Wikariusz Józef Platowski. Organista Franciszek Platowski i zakrystian Błażej Bruski. Zakonników żadnych nie było. Krótka charakterystyka obyczajów parafian, k. 82-83.

Opis stanu beneficjum, jego dochodów i spis inwentarza gospodarstwa plebańskiego, k. 83-84

L e ś n o. Kościół filialny, pod wezwaniem Podwyższenia Świętego Krzyża, patronatu Michała de Lewaldt Jezierskiego, drewniany. Opis stanu tego kościoła i jego skromnego wyposażenia w paramenty liturgiczne. Opis ołtarzy. Bractwo św. Jana Nepomucena. Szkoły nie było, k. $84-84 \mathrm{v}$.

Podczas wizytacji mieszkańcy wsi Leśno i sam kolator wyrazili pragnienie, aby był tu samodzielny proboszcz, jak dawniej i przytoczyli swoje racje, między innymi i tę, że było wystarczające uposażenia tak dla proboszcza w Brusach, jak i dla proboszcza w Leśnem. Oświadczyli ponadto, że obrazy Matki Bożej i św. Jana Nepomucena są uznawane przez wiernych jako łaskami słynące, k. 84v-85.

\footnotetext{
${ }^{29}$ Tabela na dwóch zszytych kartach.
} 
Opis beneficjum w Leśnem i jego dochodów oraz spis inwentarza kościoła filialnego oraz zabudowań plebańskich w tej wsi, k.85-86.

Protokół podpisany przez wizytatora J. Gręca i notariusza ,J. Postella, dnia 27 X 1780 r. Pieczęć, k. 86.

Dekret reformacyjny dla parafii Brusy i kościoła filialnego w Leśnem, z dnia 2 X 1780 r., podpisany i napisany przez wizytatora J. Gręca, k. 87.

Odpowiedzi na pytania wizytacyjne, spisane najprawdopodobniej osobiście przez proboszcza parafii Brusy, k. 88-95.

Odpowiedzi na pytania wizytacyjne dotyczące kościoła filialnego w Leśnem, możliwe iż spisane przez wikariusza ${ }^{30}, \mathrm{k} .96-96 \mathrm{v}$.

L ę b o r k. Wizytacja kościoła prepozyturalnego w mieście (civitas) Lęborku, przeprowadzona 27 XI 1780 r. Światynia murowana, prawa patronatu monarchy pruskiego, pod wezwaniem św. Jakuba Apostoła. Opis położenia parafii. Stan świątyni dobry. Spis wyposażenia w paramenty liturgiczne oraz opis ołtarzy. Nie było żadnego bractwa. Nie było żadnej kaplicy prywatnej katolickiej. Kaplic akatolickich było sześć. Nie było też szkoły parafialnej ani przytułku, k. 97-97v.

Opis sprawowania sakramentów, k. 97v-99.

Wykaz tabelaryczny dla parafii Lębork ${ }^{31}$, k. 98.

Proboszcz, z tytułem prepozyta, Ignacy Lniński, kanonik włocławski, doktor obojga praw, archidiakon kruszwicki, tylko niekiedy tu rezydujący. Wikariusz przy świątyni porepozyturalnej Mateusz Behr i Jan Stypp Rekowski, przebywający przy kościele filialnym Rozłazino. Organista, będący jednocześnie zakrystianem i kantorem, Ludwik Więcki. Witrykusami byli Krzysztof Gube, mieszczanin Lęborka, niepodanego imienia Toltzdorf, regens kancelarii królewskiej i Maciej Blecks, także mieszczanin. Żadnych zakonów nie było. Krótka charakterystyka parafian, k 99 .

Opis stanu beneficjum parafialnego i wykaz dochodów i rozchodów, k. 9999v.

Dokładny spis inwentarza kościoła, a więc paramentów liturgicznych i innego sprzętu kościelnego oraz inwentarz gospodarstwa plebańskiego, k. 99v-100v.

N o w a W i e ś. Kościół filialny, murowany, pod wezwaniem św. Katarzyny. Opis jego położenia i wyposażenia stan beneficjum, k. 100v-101.

G a r c z e g o r z e. Kościół filialny, zbudowany z pruskiego muru, pod wezwaniem św. Marii Magdaleny. Jego krótki opis i uposażenia, k. 101.

Ł e b i e ń. Kościół filialny, niedawno wystawiony, pod wezwaniem św. Michała Archanioła. Jego opis i uposażenie, k. 101-101v.

${ }^{30} \mathrm{Nie}$ były to pytania tak dokładne jak w przypadku parafii. Przy oprawie księgi obcięto podpis spisującego te odpowiedzi. Prawdopodobne jest, jak to widać z resztek podpisu, że był to wikariusz Józef Platowski.

${ }^{31}$ Tabela na dwóch zszytych kartach, bardzo zniszczonych. 
B i a ł o g a r d a. Kościół filialny, pod wezwaniem Oczyszczenia Najświętszej Marii Panny, niedawno przez rektora parafii odbudowana z pruskiego muru, jej opis i uposażenia, k. 101v.

R o z ł a z i n o. Kościół filialny pod wezwanie św. Wojciecha, niedawno odbudowany z pruskiego muru. Dosyć dokładny opis świątyni. Przy tej świątyni rezydował jeden z wikariuszy, Jan Styp Rekowski ${ }^{32}$, odprawiając tu w co czwartą niedzielę ${ }^{33}$. Dosyć dokładny spis paramentów liturgicznych i uposażenia, k. 101v$102 \mathrm{v}$.

B r z e ź n o. Kościół filialny, pod wezwaniem św. Małgorzaty, niedawno z drewna odbudowany, częściowo z ofiar kościelnych, częściowo przez rektora parafii. Opis nielicznych paramentów liturgicznych i stanu beneficjum, k. 102103.v.

Dekret reformacyjny dla Kocioła prepozyturalnego w Lęborku i filialnych w Rozłazinie, Brzeźniu, Nowej Wsi, Białogardzie, Garczegorzu i Łebieniu, z dnia 27 XI 1780 r., podpisany przez wizytatora Gręca, k. 102 $2^{\text {a34 }}$.

Protokół z dnia 27 XI 1780 r., podpisany przez wizytatora J. Gręca i notariusza J. Postell, z pieczęcią odciśniętą w czerwonym laku, k. 103.

L ę b o r k ${ }^{35}$. Opis kościoła parafialnego w Lęborku i świątyń filialnych w Nowej Wsi, Garczegorzu, Łebieniu, Białogardzie, Rozłazinie i Brzeźniu, k. 104$-112 \mathrm{v}$.

\section{[Dekanat mirachowski]}

Wizytacja generalna dekanatu mirachowskiego, odbyta 16 X 1780 r. Krótki opis i charakterystyka dekanatu, spisany przez wizytatora J. Gręca, k. $114^{36}$.

Odpowiedzi na 55 pytań dotyczących wizytacji dekanatu mirachowskiego, możliwe iż sporządzone przez dziekana, k. 113-115.

K o ś c i e r z y n a. Wizytacja odbyta 16 X 1780 r. Po niemiecku B e rna. Kościół prepozyturalny pod wezwaniem Świętej Trójcy. Opis położenia parafii. Świątynia murowana, konsekrowana 27 VI 1769 przez biskupa sufragana pomorskiego Cypriana Wolickiego. Prawo patronatu należało do króla [pruskiego]. Opis

${ }^{32}$ Lekcja niepewna. Poprzednio napisano Rekowski.

${ }^{33}$ Można wnioskować, że we wszystkich kościołach filialnych odprawiano raz w miesiącu.

${ }^{34}$ Przy foliacji opuszczono te kartę, dlatego została zapisana jako k. 102a. Właściwie to kartę tę dołożono po sporządzeniu całej księgi.

${ }^{35}$ Jest to protokół wizytacji tej parafii, zapewne tej co poprzednio, ale spisany inną ręką, może przez proboszcza, lub jednego z wikariuszy, dotyczący tak samego kościoła parafialnego, jak i kościołów filialnych. Możliwe iż powstał on w miejsce odpowiedzi na pytania wizytacyjne, jak przy innych parafiach.

${ }^{36}$ Jest ten opis umieszczony na odwrocie wykazu tabelarycznego dekanatu mirachowskiego, składanej podwójnej k. 114. 
stanu świątyni i wyposażenia w paramenty liturgiczne oraz ołtarzy i obrazów. Była kaplica św. Józefa, przy kościele parafialnym, zbudowana przez miejscowego prepozyta Andrzeja Zelewskiego. Druga to kaplica za miastem pod wezwaniem Świętego Krzyża, ale niewiadomo kto ja fundował. W tej kaplicy odprawiano nabożeństwo w każdy piątek. Była już znacznie zniszczona, ale mieszczanie mieli zamiar ją reperować. Przy tej kaplicy znajdował się cmentarz, gdzie także, ale na innym miejscu, chowali się akatolicy. Paramenty do sprawowania mszy zabierano zawsze $\mathrm{z}$ kościoła parafialnego. Jest uważane, że w tej kaplicy wizerunek Ukrzyżowanego, słynie łaskami. Bractwo różańcowe. We wsi Puc znajdowała się kaplica prywatna w posiadłości Karola Jezierskiego, mająca indult nas sprawowanie tam mszy. Kapelanem był bardzo stary zakonnik cysterski, który w dniach świątecznych przybywa do kościoła parafialnego, wspomagając proboszcza. Akatolicy na terenie parafii mieszkający posiadali dwie kaplice. Byli też Żydzi, ale nie posiadali synagogi, a jedynie szkolę. W szkole, bardzo zniszczonej, uczył organista Franciszek Kujawski 15 dzieci, i niejaki Bunik 13. We wsi Korne uczył 30 dzieci, osobno chłopców i osobno dziewczęta, niejaki Kurkowski. Był przytułek gdzie było około 30 podopiecznych oraz szpital. Ubodzy przebywali w swoich wsiach, k. 116-118.

Wykaz tabelaryczny stanu parafii ujęty według wsi, k. 117.

Sposób sprawowania sakramentów, k. 118-119.

Proboszczem, z tytułem prepozyta, był Andrzej Zelewski, dziekan mirachowski. We wsi Puc mieszkał wyżej wspomniany kapelan z zakonu cysterskiego. Wikariusz Jakub Permarewski. Organista Franciszek Kujawski, zakrystian Maciej Pyszki. Krótka chrakterystyka parafian. Żadnych zakonów na terenie parafii nie było, k. 119-119v.

Uposażenieparafiizwykazemdochodówzposzczególnychmiejscowości,awięc z miasta Kościerzyna i wsi: Skórzewo, Sikorzyno, Barkocin z nową wsią, Pysztowa Huta, Kaliska, Now Wieś, Szenagda, cztery osady młyńskie bez podawania nazw, osady, czy chaty zwane Cicha i Czerkwia, Nowa kolonia Ottembark, dwie chaty zwane Owśnice, kolonia Biebrznica, Pustkowie Korne, Waglikowice, Sarnowy, Cząstkowo, Klincz Mały i Duży, Wętpie, k. 120-120v.

Inwentarz kościoła parafialnego, paramentów liturgicznych, obrazów i innych sprzętów kościelnych, k. 120v.

Inwentarz gospodarstwa proboszcza, k. 120v-121.

Protokół dnia 16 X podpisał i pieczęcią opatrzył wizytator J. Gręca, proboszcz i dziekan z Pucka oraz J. Postyll, notariusz, k. 121.

Dekret reformacyjny własnoręcznie spisany i podpisany przez wizytatora, k. 122 .

Odpowiedzi na pytania wizytacyjne, podpisane przez proboszcza Andrzeja Zelewskiego, k. 123-130.

L i p u s z. Wizytacja odbyta 19 X 1780 r. Wieś parafialna ze świątynią św. Michała Archanioła, prawa patronatu króla pruskiego. Położenie parafii. Zbudowana drewna przez proboszcza miejscowego Mateusza Lipińskiego w $1739 \mathrm{r}$. Opis stanu świątyni i jej wyposażenia w paramenty liturgiczne, ołtarzy i obrazów. 
Prebend i żadnych osobnych beneficjów nie było. Bractwo różańcowe. Nie było kaplic. Znajdujący się tu akatolicy także swojej kaplicy nie posiadali. Żydów nie było Dwie szkoły. Jedna przy kościele, gdzie uczył organista Maciej Dubiałkowski, a druga we wsi Kalisz, gdzie uczył Błażej Mazurek. Zimą było około 30 uczniów, zaś latem zaledwie 1, k. 131-133.

Wykaz tabelaryczny stanu parafii, k. 132.

Sposób sprawowania sakramentów, k. 133-133v.

Proboszcz Michał Klimkowski. Wikariusza, ani innych kapłanów na terenie parafii nie było. Organista Maciej Dubiałkowski. Krótka charakterystyka parafian, $\mathrm{k} .133 \mathrm{v}-134 \mathrm{v}$.

Opis uposażenia z wykazem dochodów, ale bez wyliczania wsi. Inwentarz kościoła parafialnego, w tym i paramentów liturgicznych, ołtarzy i obrazów oraz inwentarza gospodarstwa proboszcza, k. $134 \mathrm{v}-135 \mathrm{v}$.

Protokół podpisali 19 X 1780 r. wizytator J. Gręca i notariusz J. Postell, co uwierzytelniono także pieczęcią, k. 135v.

Dekret reformacyjny własnoręcznie napisany przez wizytatora, także tegoż dnia 19 X 1780 r., k. 136.

Odpowiedzi na pytania wizytacyjne, spisane przez samego proboszcza Michała Klimkowskiego, proboszcza z Lipusza, z dodaniem spisu inwentarza gospodarstwa plebańskiego, k. 137-142v.

S t ę ż y c a. Wizytacja 12 X 1780 r. Kościół parafialny murowany we wsi Stężyca, pod wezwaniem św. Katarzyny, patronatu Jana de Lewant Jezierskiego, nie wiadomo przez kogo fundowany, ale przypuszcza się, że przez ówczesnego proboszcza, a konsekrowany w 1738 r. przez Remigiusza Łaszewskiego, biskupa $\mathrm{Macri}^{37}$. Opis położenia parafii. Stan świątyni parafialnej oraz jej wyposażenia w paramenty liturgiczne. Opis ołtarzy i obrazów. Nie było żadnych prebend. Bractwo różańcowe. Kaplic nie było. Akatolicy na terenie parafii zamieszkali także swojej kaplicy nie posiadali, Żydów nie było. Szkoły brak. Bardzo stary przytułek dla ubogich we wsi parafialnej, posiadający pewne uposażenie. Uzyskiwany dochód proboszcz rozdzielał ubogim, którzy zamieszkiwali po wsiach, k. 143-145.

Wykaz tabelaryczny stanu parafii, k. 144.

Sposób sprawowania sakramentów, k. 145-145v.

Proboszcz Marcin Płachecki. W parafii mieszkał poprzedni proboszcz Wojciech Wiconowski, który z parafii zrezygnował. Organista i zakrystian Szymon Rasztowski. Zakonników nie było. Krótka charakterystyka parafian, k. 145v$-146 \mathrm{v}$.

Opis uposażenia parafii z wyliczeniem wsi: Stężyca Szlachecka, Stężyca Królewski, Gostomie, Niesiołowice, Kamienica, Borucino, Zgorzałe, Czaple Stare, osada młyńska tej wsi [czyli Czaple Stare], Golubie, Pierszczewo, folwark Stężyca, Pierszczewko, Mszczyszewice i Żeromino. Parafia pobierała także dziesięciny tu wyliczone. Ponadto były zapisane pewne sumy dające dochody roczne. Wyli-

${ }^{37}$ Był to biskup tytularny Macri, i sufragan warmiński - zob. Nitecki, Biskupi Kościoła w Polsce, kol. 262. 
czenie dochodów i wydatków. Spis inwentarza kościelnego i inwentarza gospodarstwa proboszcza, k. 146v-148.

Protokół podpisany przez 12 X 1780 r. wizytatora J. Gręca i notariusza J. Postella oraz uwierzytelniony pieczęcią wyciśnięta w laku, k. 148v.

Dekret reformacyjny z 12 X 1780 r., własnoręcznie napisany przez wizytatora J. Gręca, k. 149.

Odpowiedzi na pytania postawione w wizytacji, spisane osobiście przez proboszcza Marcina Płacheckiego, k. 150-156.

S i e r a k o w i c e. Wizytacja odbyta 24 XI 1780 r. Kościół drewniany, pod wezwaniem św. Marcina biskupa, prawa patronatu Józefa Łaszewskiego. Opis położenia parafii. Opis tanu świątyni i wykaz paramentów liturgicznych. Opis ołtarzy i obrazów. Przy świątyni kaplica św. Barbary zbudowana niedawno przez proboszcza i parafian. Bractwo św. Barbary, posiadające własne paramenty liturgiczne. Nie było żadnej kaplicy. Także akatolicy tu zamieszkali własnej kaplicy nie posiadali. Żydów nie było. Szkoła we wsi Gowidlino zbudowana kosztem króla pruskiego gdzie uczył katolik Ignacy Stuszewski, opłacany przez władze, uczący około 30 uczniów. Przytułku brakowało, a ubodzy mieszkali po wsiach, k. $156^{\mathrm{a3} 8}-158 \mathrm{v}$.

Wykaz tabelaryczny stanu parafii, k. 157.

Opis sprawowania sakramentów, k. $158 \mathrm{v}-159$.

Przed wizytacją był proboszcz Franciszek Wejher, ale zmarł i jego miejsce miał zająć Antoni Lewiński, ale jeszcze w parafii był nieobecny. Tymczasowo obowiązki pełnił zakonnik franciszkanin ze Stolcembergu. Innych kapłanów nie było. Organista i zakrystian Adam Trowski. Zakonników nie było. Krótka charakterystyka parafian, k.159-159v.

Stan materialny parafii i wykaz dochodów i rozchodów. Spis inwentarza kościelnego i gospodarstwa proboszczowskiego, k. $159 \mathrm{v}-161$.

Protokół wizytacyjny podpisany 24 XI 1780 r. przez wizytatora J. Gręca, notariusza J. Postella, z pieczęcią, k. 161.

Dekret reformacyjny napisany własnoręcznie i podpisany 24 XI 1780 r. prze wizytatora J. Gręca, k. 162.

Odpowiedzi na pytania stawiane w punktach wizytacji, ale nie podano kto je sporządził, ale możliwe iż sam proboszcz Franciszek Wejher bezpośrednio przed śmiercią, ale brak podpisu, k. 163-168.

S t r z e p c z. Wizytacja 23 IX 1780 r. Kościół drewniany, pod wezwaniem św. Marii Magdaleny. Prawo patronatu należało do króla [pruskiego]. Opis położenia parafii. Stan świątyni i spis paramentów liturgicznych. Opis ołtarzy i obrazów. Bractwo Opatrzności Bożej. Kaplic nie było. Także akatolicy tu mieszkający nie posiadali swojej świątyni. Szkoły nie było. Przytułek na ośmiu podopiecznych, k. 169-171.

Wykaz tabelaryczny stanu parafii, k. 170.

\footnotetext{
${ }^{38}$ Pomyłka przy oznaczaniu numerów kart.
} 
Sposób. Sprawowania sakramentów, k. 171-171v.

Proboszcz Jakub Niedrzwicki. Wikariusz Maciej Mejer. Witrykusi Wojciech Patelczyk i Jan Baranowski. Organista i zakrystian Michał Bałachowski. Zakonów nie było. Krótka charakterystyka parafian, k. 171v-172v.

Stan materialny parafii. Wykaz dochodów i rozchodów. Inwentarz kościoła parafialnego i gospodarstwa proboszczowskiego, k. 172v-173v.

S i a n o w o. Wizytacja $25^{39}$ IX 1780 r. Świątynia filialna, drewniana, pod wezwaniem Narodzenia Najświętszej Marii Panny. Opis stanu tego kościoła, ołtarzy i obrazów. Szkoła publiczna w Sianowie, królewska z nauczycielem Adamen Kupiter. Uczniów powinno być 200, ale aktualnie nie buło nikogo. Nauczyciel został upomniany, że nie wypełnia swoich obowiązków, chociaż ma należyte utrzymanie, tu przedstawione. Sakramenty sprawowano tak, jak w kościele parafialnym. Zakonów nie było. Skromne uposażenia dla proboszcza. Inwentarz kościoła sianowskiego i inwentarz gospodarczy proboszcza ${ }^{40}, \mathrm{k} .173 \mathrm{v}-174 \mathrm{v}$.

Protokół wizytacyjny kościoła parafialnego w Strzepczu i filialnego w Sianowie, z dnia 23 IX 1780 r., podpisany przez wizytatora J. Gręca i notariusza J. Postella, z pieczęcia, k. $174 \mathrm{v}$

Dekret reformacyjny dla kościoła parafialnego w Strzepczu i filialnego w Sianowie z 23 IX 1780 r., napisany własnoręcznie i podpisany przez wizytatora J. Gręca, k. 175.

Odpowiedzi na artykuły wizytacyjne, sporządzone przez proboszcza parafii w Strzepczu i filii Sianowo, Jakuba Nierzwickiego i przez niego podpisane, k. $178-185$.

L u z i n o. Wizytacja 20 IX 1780 r. Kościół parafialny we wsi Luzino, murowany, pod wezwaniem Wniebowzięcia Najświętszej Marii Panny. Prawo patronat dawniej należało do zakonnic z Żukowa, a teraz do króla Prus. Opis położenia parafii. Świątynia wystawiona przez proboszcza Macieja Rzepczyńskiego w 1734 r., k. 186.

Opis stanuświątyni, jej wyposażenia w paramentyliturgiczne, opis ołtarzyi obrazów. Nie było osobnych prebend, ale trzy zapisy na odprawianie mszy w wyznaczonych intencjach. Dwa bractwa, a mianowicie Różańcowe i św. Jana Nepomucena. Nie ma kaplic. Akatolicy żądnego zboru nie posiadali. Żydów nie było. Brak przytułku i ubodzy mieszkali po wsiach. Szkoły nie było, ale uczył organista, k. 186-188.

Wykaz tabelaryczny stanu parafii, k. 187.

Opis sprawowania sakramentów, k. 188v-189.

Proboszcz Grzegorz Adam Plutowski. Wikariusz Michał Mościcki. Organista niepodanego imienia Lipiński. Żadnych zakonników nie było. Krótka charakterystyka parafian, k. 189-190.

\footnotetext{
${ }^{39}$ Ta data z pewnością została błędnie napisana, zamiast dnia 23 IX.

${ }^{40}$ Spisany w języku polskim.
} 
Opis uposażenia parafii z podaniem wsi: Luzino, osada młyńska Luzino, Gowino, Strzebielino, Dąbrówka, niepodanej nazwy osada młyńska, Malwino, Cząstkowo, Wyszecino, Barłomino, Rybakowo, Gościcino, niepodanej nazwy osada młyńska, Kambłowo, Sopieszyno, Ustarbowo, niepodanej nazwy osada młyńska, Przytoczyno. Opis dochodów i rozchodów, Inwentarz kościoła parafialnego i gospodarstwa plebańskiego, k. 190-191v.

Protokół powizytacyjny podpisany przez wizytatora Gręca i notariusza Postella, z pieczęcią, k. 191v.

Dekret reformacyjny osobiście spisany i odpisany przez wizytatora, k. 192.

Odpowiedzi na punkty wizytacyjne postawione 20 IX 1780 r., bardzo dokładnie podane przez proboszcza Grzegorza Adam Plutowskiego, k. 193-208.

C h m i e 1 n o. Wizytacja 28 IX 1780 r. Kościół we wsi parafialnej Chmielno, drewniany, pod wezwaniem świętych Piotra i Pawła, dawniej prawa patronatu zakonnic z Żukowa, a teraz króla pruskiego. Opis położenia parafii. Stan świątyni wymagającej pilnie naprawy. Spis paramentów liturgicznych, ołtarzy i obrazów. Prebend nie było. Bractw nie było. Nie było kaplic. Akatolicy posiadali swój cmentarz we wsi Łączyn. Niekiedy małżeństwa akatolików były zawierane w kościele parafialnym, a często inni udawali się do swego ministra poza parafię. Nie było szkoły. Przytułek we wsi parafialnej, fundowany dawniej przez proboszcza z Chmielna Macieja Kręckiego, k. 208-210.

Wykaz tabelaryczny stanu parafii, k. 209.

Opis sprawowania sakramentów, k. 210-211.

Proboszcz Michał Witk Niepoczołowski, notariusz apostolski. Wikariusz Antoni Lewiński. Organista Józef Prowski. Zakonników nie było. Krótka charakterystyka parafian, k. 211-212.

Stan uposażenia parafii w wykazem wsi parafialnych: Folwark Chmielno, osada młyńska, Chmielno, Zawory, Remboszewo, Brodnica Górna, Łączyn, osada młyńska Łączyńska, Borzestowo, Miechucino, Czeszenie, Reckow2o, Pożyczkowo, Prokowo, Garcz, Kossy, Łapalzie ${ }^{41}$, Smętowo i Lipowiec. Wykaz dochodów i rozchodów oraz inwentarz kościoła parafialnego i gospodarstwa plebańskiego, k. 212-213v.

Protokół na zakończenia wizytacji z dnia 28 IX 1780 r., podpisany przez wizytatora J. Gręca i notariusza J. Postella z pieczęcią, k. 213v-215.

Dekret reformacyjny napisany i podpisany przez wizytatora J. Gręca, z dnia 28 IX 1780 r., k. $214^{42}$.

Odpowiedzi na postawione pytania wizytacyjne, sporządzone przez proboszcza z Chmielna Michała Witk Niepoczołowskiego, k. 216-225v.

G o r ę c z y n o. Wizytacja 2 X 1780 r. Kościół parafialny, murowany, fundowany w 1739 r., przez niejakiego Kacpra, zakonnika Kartuzów, prokuratora tego zakonu, konsekrowany przez Cypriana Wolickiego, sufragana pomorskiego 21 IX

\footnotetext{
${ }^{41}$ Lekcja niepewna.

${ }^{42}$ Karta ta została dołączono po sporządzeniu księgi, stąd poprzedni zapis na dwóch kartach.
} 
1772 r pod wezwaniem Świętej Trójcy i Wszystkich Świętych, którego prawo patronatu dawniej należało do zakonu kartuzów, a teraz do króla pruskiego. Położenie parafii. Opis stanu świątyni i jej wy[osmażenia w paramenty liturgiczne, ołtarzy i obrazów. Kaplic żadnych nie było, a tylko świątynia filialna we wsi Kiełpino. Bractwo różańcowe. We wsi Kartuzy kaplica publiczna, murowana, z cmentarzem, należąca do zakonników Kartuzów, pod wezwaniem św. Katarzyny. Proboszcz odprawia tu kilka razy w roku i z racji pogrzebów. W dni powszednie odprawia msze dla mieszkańców prokurator Kartuzów. Inna kaplica, pod wezwaniem Świetego Krzyża znajdowała się na wzgórzu Spycbarch, niedaleko klasztoru, teraz opuszczona, ale dawniej każdego piątku odprawiał tu przeor, albo prokurator zakonu. Akatolicy posiadali swoje oratorium z cmentarzem we wsi Szymbark, oraz prywatne cmentarze w swoich wsiach. Żydów nie było. Szkoła królewska we wsi parafialnej, uczył katolik Stanisław Moskierski, opłacany przez rząd i miał około 20 uczniów. Przytułku nie było a ubodzy przebywali w swoich wioskach, k. 226-228

Tabelaryczny wykaz stanu parafii, k.22743.

Sposób sprawowania sakramentów, k. 228-229.

Proboszcz Wojciech Nepomucen Rykowski. Wikariusz Maciej Pormita ${ }^{44}$. Organista Paweł Bykowski. Witrykusi Andrzej Marszałkowski, Jakub Markowski i i Mateusz Magulski. Na terenie parafii przebywało 8 kapłanów zakonników kartuskich i 2 braci laików 2. Poza wypadkami konieczności, nie mieszają się do sprawowania sakramentów. zakonnic nie było. Krótka charakterystyka parafian, k. 229-230.

Stan beneficjum i jego uposażenie. Były zapisy na parafie, tu wymienione, na co był dokument wystawiony w Warszawie 15 VI 1740 r. Parafie tworzyły wsie: Goręczyno, Kiełpino, Ostrzyce, Nowe Czaple, Ronty, Słomkowy, Wyczechowo, Borcz, Połuty, Poluszyno, Egiertowa Huta, Kamila, Nowa Wieś, Kapelowa Huta, Staerkowa Huta, Dypedal Huta, Czarna Huta, Ossenkop Huta, Ekmuc Huta, Kolano, Hoppendorf. Wykaz dochodów i wydatków. Inwentarz kościoła parafialnego i gospodarstwa plebańskiego, k. 230-231v.

K i e $\nmid$ p i n o. Wizytacja 3 X 1780 r. Wieś z kościołem filialnym, murowanym i fundowanym w 1647 r. przez przeora Kartuzów, pod wezwaniem św. Michała Archanioła. Opis stanu świątyni, ołtarzy, obrazów. Żadnego bractwa nie było. Sprawowanie sakramentów, tak jak w kościele parafialnym, ponieważ tu odprawiał albo proboszcz, albo wikariusz. Stan uposażenia, inwentarz kościoła filialnego i miejscowego zabudowania gospodarczego, k.231v-232v.

Protokół wizytacyjny dla kościoła parafialnego w Goręczynie i filialnego w Kiełpinie, podpisany przez wizytatora J. Gręca, notariusza J. Postella, z pieczęcią, z dnia 2 X 1780 r., k. 232v.

Dekret reformacyjny dla kościła parafialnego i filialnego, z tego samego co wyżej dnia, napisany i podpisany przez wizytatora J. Gręca, k. 233.

\footnotetext{
${ }^{43}$ Tabela na dwóch kartach ze sobą złączonych.

${ }^{44}$ Lekcja niepewne.
} 
Odpowiedzi na pytania wizytacyjne dotyczące kościoła parafialnego w Goręczynie, podpisane przez proboszcza Wojciecha Nepomucena Rykowskiego, k. 234-240v.

Odpowiedzi na pytania dotyczące kościoła filialnego w Kiełpinie, podpisane także przez proboszcza goręczyńskiego, Wojciecha Nepomucena Rykowskiego, k. 241-243v.

G r a b o w o. Wizytacja 8 X 1780 r. Wieś parafialna ze świątynią murowana, pod wezwaniem św. Anny. Dawniej prawo patronatu należało do zakonników kartuzów, a teraz do króla pruskiego. Położenie parafii. Stan świątyni murowanej dobry i jej opis wyposażenia, ołtarzy i obrazów. Nie było żadnych prebend, bractw, ani kaplic prywatnych. Akatolicy tu mieszkający swojego zboru nie posiadali. Żydów nie było. W szkole królewskiej uczył katolik, Ignacy Pokejzer, wynagradzany przez rząd. Uczniów zima około 30. Przytułku brak, a ubodzy mieszkali po wioskach, k. 244-244v.

Opis sprawowania sakramentów, k. 244v-246v.

Tabelaryczny wykaz stanu parafii, k. 245.

Proboszcz Marcin Antoni Pellowski. Wikariusza nie było. Organista Jakub Hilbrant. Zakonników na terenie parafii nie było. Krótka charakterystyka parafian, k. 246v-247.

Stan beneficjum parafialnego, ale bez wykazu wsi parafialnych. Wykaz dochodów i wydatków. Inwentarz kościoła parafialnego i gospodarstwa plebańskiego, k. 247-248.

Protokół powizytacyjny, z dnia $8 \times 1780$ r., podpisany przez wizytatora J. Gręca i notariusza J. Postella, z pieczęcią, k. 248-248v.

Dekret reformacyjny z dnia 8 X $1780 \mathrm{r}$. spisany osobiście przez wizytatora J. Gręca, k. 249.

Odpowiedzi na pytania postawione podczas wizytacji, sporządzone przez proboszcza Marcina Antoniego Pellowskiego, k. 250-255v.

\section{G70}

\section{A.OPIS KSIĘGI}

[1. Sygn. Akt.] G70.

[2. Tytuł oryg.] Visitatio generalis ecclesiarum Decanatuun Dirschaviensis et Starogardiensis ex mandato Illustrissimi et Reverendissimi Domini Domini Josephi Rybiński episcopi loci ordinarii Vladislaviensis ac Pomeraniae, per Perillustrem Admodum Reverendum Lucam Joannem Krzykowski, canonicum Crusviciensem, notarium apostolicum, visistatorem delegatum, peracta anno 1780-mo.

[3. Daty krańc.] 1780, 1781.

[4. Opis zewn.] Łac.-pol. $(36,0 \times 22.0 \mathrm{~cm})$. Stron paginowanych 456. Liczne pomyłki przy paginacji. Księga pisana różną ręką. Fragmenty opisów stanu świątyń, czy wyposażenia, jak również wykazy inwentarzy, często sporządzone w ję- 
zyku polskim. Strony puste: $1 \mathrm{v}, 3$, s. $8 \mathrm{v}, 18 \mathrm{v}, 51 \mathrm{v}, 52 \mathrm{v}, 61 \mathrm{v}, 73 \mathrm{v}, 74 \mathrm{v}, 82 \mathrm{v}, 91 \mathrm{v}$, $107 \mathrm{v}, 139 \mathrm{v}, 140 \mathrm{v}, 148 \mathrm{v}, 149 \mathrm{v}, 157 \mathrm{v}, 158 \mathrm{v}, 177 \mathrm{v}, 180 \mathrm{v}, 186 \mathrm{v}, 187 \mathrm{v}, 209 \mathrm{v}, 179 \mathrm{v}$, $321 \mathrm{v}, 331 \mathrm{v}, 332 \mathrm{v}, 380 \mathrm{v}, 380^{\mathrm{a}} \mathrm{v} ; 351 \mathrm{v}, 378 \mathrm{v}, 384 \mathrm{v}, 387 \mathrm{v}, 402 \mathrm{v}, 411 \mathrm{v}, 421 \mathrm{v}, 428 \mathrm{v}$, $433 \mathrm{v}, 434 \mathrm{v}, 439 \mathrm{v}, 440 \mathrm{v}, 446 \mathrm{v}, 447 \mathrm{v}$.

[5. Uwagi] Jest dużo wiadomości do biogramów księży. Przy ich charakterystyce podawano zaraz jak sprawują duszpasterstwo. W tym miejscu zapisywano także porządek nabożeństw, a także czy prowadzili proboszczowie księgi metryk. Sprawdzano także w tym miejscu, czy zostały wypełnione zalecenia z poprzednich wizytacji.

Cenne są wykazy tabelaryczne, ale niektóre tabele bardzo zniszczone. Należałoby je przynajmniej podkleić, żeby nie zaginęły.

Odpowiedzi na pytania wizytacyjne, spisywane przez zainteresowanych proboszczów, są niezwykle dokładne, niekiedy obszerniejsze aniżeli sam protokół wizytacyjny, ale są parafie, gdzie tych odpowiedzi nie ma. Żeby je przytaczać, należałoby poświecić wiele czasu i miejsca. Dlatego zainteresowanych odsyła się do rękopisu księgi. Odpowiedzi jednak nie były traktowane osobno, ale są to właściwie powtórzone, tyle, że nieco dokładniej, wiadomości z samego protokołu wizytacyjnego. Ponieważ pytań było 328, stąd niektórzy proboszczowie odpowiadali na każde pytanie.

Księga zapewne skompletowana i oprawiona po zakończeniu wizytacji, bo są różne formaty kart. Niektóre karty zostały wklejone do księgi po jej oprawie.

Nazewnictwo miejscowości niekiedy nieznacznie się zmieniało. Tym razem pozostawiono je $\mathrm{w}$ formie napisanej $\mathrm{w}$ księdze. Niekiedy podawano brzmienie niemieckie.

Każdą parafię opisano, jakie było jej oddalenie od głównych centrów diecezji i podawano wykaz graniczących parafii.

Same opisy wyglądy świątyń, stanu zabudowań plebańskich, często pisano w języku polskim.

Niekiedy pomiędzy tekst wklejano kartę, która nosi kolejną numerację, chociaż poprzedni zapis znajduje swoje zakończenie na karcie po niej następującej.

Podpisując protokół wizytacyjny, wizytator zawsze dawał pieczęć z napisem „In fide et iustitia et fortitudo”. Napis na pieczęci najczęściej nie jest czytelny.

\section{B. ZAWARTOŚĆ KSIĘGI}

Wewnętrzna strona okładki z napisem niemieckim i pieczęcią, która w polu ma napis Pelplin a w otoku Archiwum Diecezji Chełmińskiej.

Tytuł jak wyżej na karcie pierwszej niefoliowanej.

Visitatio Generalia Decanatus Derschaviensis in Dioecesis Pomerana peracta 1780 , s. 1.

Opis położenia dekanatu tczewskiego, którego dziekanem był Andrzej Józef Schultz, kanonik kruszwicki, proboszcz parafii Kiszewa i Polaszki. Uwagi, że odpowiedzi na szczegółowe pytania będą na osobnych kartach. Podpis wizytatora Łukasza Jana Krzykowskiego, z pieczęcią w czarnym tuszu, k. 2-2v.0-2v. 
Zestawienie tabelaryczne dekanatu tczewskiego. Tabela bardzo zniszczona, ale czytelna, k. 3 .

Tczew, z kościołem filialnym Lubiszewskim, z klasztorem dominikanów. Proboszcz Franciszek Piechowski, ale niezbyt często rezydujący; Skarszewy z kościołem filialnym w Szczodrowie, proboszcz Joachim Wybicki i wikariusz Józef Landsberg; Subkowy z kościołem filialnym Gorzędziej, proboszcz Wincenty Schulz, zarządca Ludwik Juchniewicz, wikariusz Feliks Łyzakowski, zakonnik dominikanin; Miłobądz z kościołem filialnym w Dalwinie, proboszcz Karol Ansitio, zarządca Jan Waralski, wikariusz Stanisław Zaremba; Godziszewo z kościołem filialnym w Obozinie, proboszcz Ludwim Modlibowski z zakonu cystersów; Giemlice, proboszcz Józef Dubiszewski, wikariusz Piotr Kielman; Trąbki, proboszcz Jan Zaręba; Wiśniewo, proboszcz Stanisław Wylma; Garczyn, proboszcz Stanisław Kaliszewski; Niedamowo, zarządca Piotr Piątkowski, k. 3.

Opis dekanatu tczewskiego, ujęty w 12 punktów, z wyliczeniem parafii i jej duszpasterzy, sporządzony przez dziekanaAndrzeja Schulza. Opis ten przyjętyipodpisany przez wizytatora dnia 19 IX 17870 r., k. $4-5 \mathrm{v}^{45}$.

S k a r s z e w y. Wizytacja generalna kościoła parafialnego w Skarszewach, odbyta w 1780 r. U góry karty zaznaczono: Diecezja pomorska; dekanat tczew$\mathrm{ski}^{46}, \mathrm{k} 8$.

Zestawienie tabelaryczne parafii Skarszewy.

Skarszewy z przyległościami liczyły katolików 394, komunikujących 333, akatolików 1355 i 150 Żydów; Demblin 82, 62, 96; Nygut 31, 24, 27; Bożepole 6, 4, 22; Czarnocin 6, 3, 36; Suchahuta jedynie 56 akatolików; Barhuta jedynie 66 akatolików; Górne Piekło jedynie 47 akatolików, Czashuta 2, 1, 49; Sztrukhuta jedynie 120 akatolików; Granicznik jedynie 20 akatolików; Elemsbruk 1, 1, 54; Szczodrowo z przyległościami 173, 131, 49; Kamirowo z przyległościami 64, 49, 56; Zapowiednik 24, 18, 6; Czysta Woda i Trzcionka5, 3, 13; Czarnocińskie Piece 4, 4, 16, Mirowo 70, 54, 9; Kiwpon jedynie 6 akatolików; Nowy Wiełc 99, 72, 10; Pawłowo z przyległościami 44, 31, 49; Pawłoko jedynie 32 akatolików; Paltembarg z przyległościami jedynie 32 akatolików; Pustkowia 2. Proboszczowskie, 15, 9, 13. Zatem parafia liczyła 24 wsie, 1020 katolików, w tym 799 przystępujących do sakramentów wielkanocnych. Ponadto na terenie parafii zamieszkiwało 2280 akatolików i 150 Żydów, k. $9^{47}$.

Opis parafii Skarszewy. Świątynia pod wezwaniem św. Michała. Określenie położenia parafii, także w stosunku do najważniejszych ośrodków diecezji. Kościół z 7 ołtarzami. Zakrystia wyposażona wystarczając. Opis znajdujących się

${ }^{45} \mathrm{Na}$ początku księgi nie stosowano jednej numeracji stron. Karta tytułowa nie została zaznaczona. Następnie karty 1, 2 i 3, na której została spisana tabela dekanatu tczewskiego. Opuszczono karty 6 i 7.

${ }^{46}$ Zawsze u góry karty rozpoczynającej opis wizytacyjny podawano notatkę, że chodzi o diecezje pomorska i dekanat tczewski, a potem starogardzki.

${ }^{47}$ Przedstawiając treść tabel, najpierw podawano opisowa ilu było katolików, osób spowiadających się na Wielkanoc, innowierców i Żydów, a potem odpowiednio w tej kolejności podawano liczby 
obrazów. Nie było osobnych prebend. Bractwo św. Anny z własnym uposażeniem i paramentami liturgicznymi. Zbór protestancki w Skarszewach. Dwie szkoły, ale utrzymywane przez rząd. Był przytułek, ale bez własnej świątyni, którym opiekował się proboszcz. Opis uposażenie tego przytułku, k. 10-11.

Sposób sprawowania sakramentów, k. 11v.

Proboszcz Joachim Wybicki. Wikariusz Józef Landsberg. Nie było zakonników. Krótka charakterystyka parafian. Organista, a jednocześnie zakrystian, niepodanego imienia Pieczewski, k. 12-12v.

Opis uposażenia parafii. Wykaz miejscowości parafialnych z podaniem oddawanego przez ich mieszkańców mesznego, a także dziesięcin. Następnie podano wydatki. To, co pozostało, przeznaczone było dla proboszcza, k. 12v-14.

Opis stanu murowanej świątyni w Skarszewach i jej wyposażenia w paramenty liturgiczne, , k. 14-14v.

Zabudowania plebańskie i dokładny inwentarz, tak ksiag, jak i gospodarstwa. Stan domu organisty i szpitala, wyremontowanego w $1780 \mathrm{r}$. przez aktualnego proboszcza, w którym przebywało sześciu podopiecznych, k. 15-15v.

S z c z o d row o. Opis kościoła filialnego w S z c zodrow i e pod wezwaniem św. Szymona i Judy Apostołów. Świąynia drewniana $z$ trzema ołtarzami. Wykaz inwentarza. Nie było własnego uposażenia kościoła, a świątynię utrzymywano z ofiar. Dla proboszcza jednak były cztery włoki, znajdujące się w dzierżawie, k. 15-18.

Protokół wizytacyjny podpisany w Skarszewach dnia 19 X 1780 r., przez wizytatora Łukasza Krzykowskiego. Sekretarzem był Maciej Formela. Pieczęć z napisem w otoku: ,in fide et iustitia fortitudo", k. $18^{48}$.

Dekret reformacyjny dla parafii i filii, wystawiony 19 X 1780 r., spisany i podpisany przez samego wizytatora Jana Krzykowskiego, k. $16^{49}$.

Odpowiedzi szczegółowe na pytania wizytacyjne. Sporządzone zostały przez proboszcza Joachima Wybickiego, jednakże w formie ogólnej, jak sam protokół wizytacyjny. Osobno podano także odpowiedzi na temat świątyni w Szczodrowie. Te odpowiedzi zostały przyjęte i potwierdzone własnoręcznym podpisem przez wizytatora, w dniu 19 X 1780 r., k. 19-38v.

S u b k o w y. Odpowiedzi na pytania wizytacyjne z parafii Subkowy ${ }^{50}$. Opis stanu świątyni w Subkowach pod wezwaniem św. Stanisława Biskupa. Określenie położenia parafii w stosunku do ważnych miejscowości diecezjalnych. Świątynia, zapewne murowana, znajdująca się w stanie dobrym. Zakrystia wyposażona w potrzebne paramenta. Było sześć ołtarzy, tu opisanych. Krótki opis znajdujących się obrazów. Znajdowały się tu relikwie, także Krzyża Świętego z dokumentem autentyczności, orz jeszcze inne. Bractwo Różańcowe z własnym uposażeniem i wyposażeniem w paramenty liturgiczne tu wyliczonym. Oratorium prywatne,

${ }^{48}$ Ta pieczęć znajduje się na końcu wszystkich dekretów reformacyjnych.

${ }^{49}$ Karta wklejona jako 16. Następną zapisano już przez pomyłkę jako kartę 18.

${ }^{50} \mathrm{Nie}$ wiadomo dlaczego nie ma właściwego protokółu wizytacyjnego, ale zaraz odpowiedzi na pytania wizytacyjne. Odpowiedzi te wystarczają jednak za sam protokół. 
a raczej kaplica murowana, z trzema ołtarzami, we wsi Radostowo, należącej do opactwa cysterskiego w Oliwie, przy której przebywał jeden z zakonników cystersów. Szkoła parafialna w Subkowach, gdzie uczył Jan Staszewski, ale opłacany przez rząd. Przytułek w Subkowach, bez własnego funduszu, a przebywały w nim trzy kobiety i jeden mężczyzna, k. 39-42v.

Zestawienie tabelaryczne parafii Subkowy, k. 41. Subkowy, katolików 645, spowiadających się na Wielkanoc 230, innowiercy 5, Żydów nie było; Gorzędziej 270, 230, 3; Waćmierz 130, 100, akatolików i Żydów wnie było; Waćmierek 50, 25, 12; Gniszewa 60, 41, 1; Piaski 13, 11; Czarlin 24, 16; Wielogłowy 100, 50; Brzezno 101, 65, 5; Narkowy 15, 7, 4; Wielka Słonia 151, 91; Mała Słonia 16496, 4; Gartz 90. 53, 3; Radostowo 140, 119; Brzusce 136, 96; Starenczyn 42, 29; Łowiguz 4, 4, 3; Fyszbudy 25, 19; Kempa 4, 3, 4. Ogółem więc katolików było 2141, akatolików 1300 i 46 Żydów, k. 41.

Sposób sprawowania sakramentów, k. 42v-43.

Rektorem kościoła był Wincenty Ignacy Schulz, kanonik włocławski i sędzia surogat oficjałatu gdańskiego. W parafii było archiwum z dokumentami, a także biblioteka. Byli jeszcze dwaj kapłani zatrudnieni w duszpasterstwie, ale nie nazwano ich wikariuszami, Ludwik Ruchniewicz i Feliks Łysakowski. Organista Gabriel Felchner i dzwonnik kościelny Antoni Czajkowski. Zakonników nie było. Krótka charakterystyka parafian, k. 43-44.

Opis uposażenia parafii. Wykaz oddawanego mesznego z poszczególnych wsi parafialnych. Wykaz dochodów i wydatków, k. 44-45v.

Opis bardzo dokładny świątyni murowanej oraz zabudowań plebańskich. Spis inwentarza kościelnego i gospodarczego ${ }^{51}, \mathrm{k} .46-48 \mathrm{v}$.

G o r z ę d z i e j. Wizytacja kościoła filialnego pod wezwaniem św. Wojciecha we wsi Gorzędziej. Złączona z parafia Subkowy w 1646 r. Znajdowały się w niej dwa ołtarze. Szkoły ani przytułku dla ubogich tu nie było. Bractwa nie było, zaś przywilej odpustowy na święto św. Wojciecha. Nabożeństwa w co trzecią niedzielę. Opiekę miał wikariusz lub inni kapłani z kościoła macierzystego. Podano dokładny opis świątyni starej, z prezbiterium murowanym w pruski mur. Wykaz uposażenia $\mathrm{i}$ inwentarza. Ten opis sporządzony przez księdza Juchniewicza, nazwanego tu zarządcą parafii Subkowy, potwierdzony przez wizytatora w dniu 9 X 1780 r., k. 49-50v.

Dekret reformacyjny dla parafii Subkowy, wystawiony przez wizytatora w dniu 9 X 1780 r., k. 51.

M i $\nmid$ o b ą d z. Wizytacja generalna, kościoła parafialnego miłobądzkiego przeprowadzona w 1780 r., k. 52 .

Kościół pod wezwaniem św. Małgorzaty, prawa patronatu miejscowego ordynariusza. Opis położenia parafii. Świątynia murowana z takąż wieżą, konsekrowana, k. 53.

${ }^{51} \mathrm{~W}$ języku polskim. 
Wykaz tabelaryczny parafii ułożony miejscowościami, które wszystkie znajdowały się w Prusach w powiecie tczewskim. Podano tu dokładne dane wg porządku: Wieś Miłobądz, właściciel biskup włocławski, liczba katolików 333, komunikujących na Wielkanoc 257, akatolików i Żydów nie było; Malenin, biskup włocławski, 166, 126, 6; Mieszczyn, biskup włocławski, 149, 106, 7; Dabrówka, król pruski, 169, 122, 7; Dalwin, król pruski , 115, 80, 16; Zajączkowo, 91, 72, 8; Szpęgawa,34,19, 15; Kolink, 84, 60, 115; Pszczółki, 149,115, 121; Łukocin, 89,67,9; Żenisławki, 82, 60, 29; Rembielty 2, 2, 359. Zatem ogółem było w parafii 1463 katolików z czego komunikujących na Wielkanoc 1086, akatolików 692, a Żydów nie było, k. 54.

Opis stanu świątyni, wyposażenia i ołtarzy. W kościele znajdowały się relikwie liczne relikwie, także Krzyża Świętego, posiadające dokumenty autentyczności z Rzymu. Były także przywileje odpustowe. Bractwo Różańcowe. We wsi Rembielty (Rembiltz) znajdował się zbór akatolicki. Szkoły utrzymywane przez rząd w Miłobądz i Dąbrówce. Nauczyciel w Miłobądz Antoni Jankowski, zarazem organista, a uczniów 29. W Dąbrówce uczył Leopold Loeber, uczniów katolików 23. Przytułek w Miłobądzu, gdzie było czterech podopiecznych. k. 53-55.

Sposób administrowania sakramentów, k. 55-55v.

Proboszcz Karol Ksawery de Ansicio, Włoch, kan. warszawski, od 1774 r., rzadko tu przebywający. Duszpasterstwo sprawują wikariusze: Jakub Waralski, lat 36 i Stanisław Zaremba lat 29. Organista niepodanego nazwiska, jest od 1778 r., ponadto także dzwonnik, niepodanego nazwiska. Zakonników nie było. Opis obyczajów wiernych, k. 55v-56.

Opis stanu beneficjum, spis gruntów, dziesięcin i pozostałego uposażenia. Wykaz pobieranych dziesięcin z poszczególnych wsi, k. 56-56v.

Opis świątyni murowanej. Spis inwentarza kościelnego, bardzo bogatego. Stan zabudowań i spis inwentarza, k. 56v-59v.

D a 1 w i n. Opis kościoła filialnego w Dalwinie. Świątynia drewniana, pod wezwaniem św. Mikołaja, z wieżą, w stanie złym. Wykaz inwentarza kościelnego, k.59-60.

Spis inwentarza gospodarczego, żywego i martwego „plebanii”, k. 60.

Spis inwentarza sprzętów, wotów i innych rzeczy należących do bractwa Różańcowego w parafii Miłobądz, k. 60v.

Niniejszy protokół podpisał dnia 5 X 1780 r. wizytator Łukasz Jan Krzykowski i sekretarz Maciej Formela i potwierdzono to pieczęcia, k. 60v.

Dekret reformacyjny dla parafii Miłobądz i kościoła filialnego we wsi Dalwin, z dnia 5 X 1780 r., napisany i podpisany przez wizytatora Krzykowskiego, k. 61v,

Pytania i odpowiedzi z racji wizyty generalnej parafii Miłobądz, sporządzonego przez zarządce [Jakuba] Waralskiego i podpisane przez wizytatora Łukasza Jana Krzykowskiego, dnia 5 X 1780 r., k. 62-73 5 .

\footnotetext{
${ }^{52}$ Napisane na papierze mniejszego formatu niż całość księgi.
} 
G o d z i s z e w o. Wizytacja generalna kościoła parafialnego w Godziszewie przeprowadzona w 1780 r., k. 74

Kościół e Godziszewie pod wezwaniem św. Jana Nepomucena, prawa patronatu zakonników, czyli Benedykta Lubstowskiego, opata cystersów z Lądu. Opis położenia parafii, k. 75 .

Wykaz tabelaryczny parafii wg miejscowości leżących w Prussach w woje3wództwoe pomorskim i powiecie tczewskim. Godziszewo, własność opata $z^{53}$ Lądu, katolików 213, komunikujących 227, akatolików 47, Żydów nie było; Gołębiowo Średnia, 86, 70, 57; Boroszewo Wielkie z młynem, 86, 63, 17; Boroszewo Małe 37, 25, 3; Damaszka 41, 29, 22; Gołębiewo Wielkie 110, 106, 11; Gołębiewo Mał 51, 39, 4; Kobierzyn 29, 22, 13; Scierbięcin 111, 75, 13; Turze Wielkie 93, 73, 4; Turze Małe nie było zamieszkałe; Obozin 216, 171, 59; Trzcińsk 115, 89, 14, Razem w parafii było 1203 wiernych, komunikujących 909, akatolików mieszkało 264 osoby, a Żydów nie było, k. 76.

Opis ołtarzy i obrazów, relikwii i przywilejów odpustowych. Bractwo św. Franciszka i Różańcowe, k. 76-77v.

Kaplic publicznych nie było. Kaplica prywatna na dworze w Gołębiewie, gdzie kapelanem od $1770 \mathrm{r}$. był zakonnik dominikanin, k. 77v.

Szkoły nie było, ale nauczyciel nazwiskiem Jankowski uczył 19 dzieci obojga płci. Przytułku nie było, k. 77v.

Sposób sprawowania sakramentów, k. 78-78v.

Proboszcz Ludwik Modlibowski, zakonnik z Lądu. Zakonników innych nie było. Wikariuszem był także zakonnik cysterski Jan Nepomucen Holzer. Witrykusi Franciszek Czamański i Marcin Chynowski. Organista Mikołaj Jankowski. Stan moralny parafian oceniany jako dobry, k.79-79v.

Opis uposażenia i dochodów z mesznego, oddawanego z poszczególnych wsi, k. $79 \mathrm{v}-80$.

Opis kościoła parafialnego w Godziszewie, Świątynia murowana, pod dachówką. Ołtarzy pić. Wyposażenie w paramenty liturgiczne bogate, k. 80-80v.

$\mathrm{O}$ b o z i n. Krótki opis kościoła filialnego w Obozinie, z pruskiego muru, pod wezwaniem św. Michała. Trzy ołtarze., 81v.

Dekret reformacyjny dla parafii Godziszewo i kościoła filialnego w Obozinie, podpisany dnia 21 X 1780 r. przez wizytatora Krzykowskiego, k. 81 .

Inwentarz kościoła parafialnego w Godziszewie, k. 82.

Protokół wizytacji generalnej parafii Godziszewo podpisany w dniu $21 \mathrm{X}$ 1780 r. przez Wizytatora Krzykowskiego i sekretarza Formela, k. 82.

Pytania i odpowiedzi przy wizytacji parafii Godziszewy i kościoła filialnego w Obozinie, sporządzony przez księdza Ludwika Modlibowskiego i podpisany przez Krzykowskiego dnia 21 X 1780 r., k. 83-92v.

G i e $\mathrm{m} 1$ i c e. Wizytacja generalna kościoła parafialnego w Giemlicach przeprowadzona w 1780 r., k. 91.

\footnotetext{
${ }^{53}$ Pewnie pomylono tu kolejnoć zapisu.
} 
Świątynia pod wezwaniem św. Jana Chrzciciela, prawa patronatu Jezuitów z Szotlandu pod Gdańskiem. Opis położenia parafii, k. 92.

Wykaz tabelaryczny podaje, iż parafię tworzy jedna wieś Giemlice, gdzie było 292 katolików, komunikujących 242 i akatolików 5, k. 93, Żydów nie było.

Opis świątyni drewnianej, znajdującej się w dosyć dobrym stanie, jej wyposażenie, ołtarze i obrazy. Nie było relikwii. Odpust na św. Jana i św. Michała Archanioła. Bractwo Różańcowe, kaplic żadnych nie było. Szkoła, w której uczył Wawrzyniec Marszewski. Przytułku nie było, k. 92-94.

Opis sprawowania sakramentów, k. 94-94v.

Proboszcz Józef Dubiszewski, rezydujący i sam sprawujący duszpasterstwo. Wikariusz Piotr Kellmann, lat 28. Zakonników nie było. Stan moralny parafian oceniony jako dobry, k. $94 \mathrm{v}-95 \mathrm{v}$.

Opis beneficjum. Był zapis uczyniony przez Jakuba Krieger, ulokowany na dobrach Konstancji Langmesser. Wykaz dochodów proboszcza, k. 95v-96.

Opis kościoła w Giemlicach i jego wyposażenia w paramenty liturgiczne, k. $96-97 \mathrm{v}$.

Wykaz zabudowań i inwentarza plebańskiego, k. 98.

Ochrzczonych w ostatnim roku było 18 , małżeństwa zawarło 7 par, zmarłych było 7. Spowiadało się parafian 242, a przybyłych spoza parafii, z Wyspy Gdańskiej, 900, k. 98.

Protokół podpisany 1 X 1780 r. przez Krzykowskiego i Formela, k. 98v.

Dekret reformacyjny dla parafii Giemlicze, k. 99.

Pytania i odpowiedzi przy wizytacji parafii Giemlicze, sporządzone przez księdza Józefa Dubiszewskiego i podpisane przez Krzykowskiego, k. 100-107.

T r ą b k i. Wizytacja generalna kościoła parafialnego w Trąbkach, przeprowadzona w 1780 r., k. 108.

Świątynia pod wezwaniem Wniebowzięcia NMP. Prawa patronatu króla pruskiego. Opis położenia parafii, k. 108-109v.

Wykaz tabelaryczny miejscowości parafialnych, położonych w województwie pomorskim i powiecie tczewskim. Trąbki Wiwelkie113, 88, 6; Sobowidz, 97, 66, 65; Klepiny, 36, 25, 9; Postojowo 66, 48, 17; Ołganowo 123, 91, 18. Zatem w parafii było 435 katolików, w ty, spowiadających się na Wielkanoc 318. Na terenie parafii mieszkało 115 akatolików, a Żydów nie było, k. 110.

Opis kościoła parafialnego w stanie dobrym. Wyposażenie, opis ołtarzy i obrazów. Nie było relikwii. Odpusty z racji bractwa różańcowego, które przy parafii istniało i miało swoje wyposażenie, tu wyliczone. Kaplic publicznych i prywatnych nie było. Szkoły i przytułku także nie było, k. 109v-112v.

Sposób sprawowania sakramentów, k. 112v-114.

Proboszcz Jan Zaremba i sam sprawował duszpasterstwo. Zakonników nie było. Krótka charakterystyka stanu moralnego parafian, k. 114-116.

Opis stany beneficjum i dochody proboszcza, k. 116-118.

Opis kościoła zbudowanego w latach 1739-1740 kosztem Konstancji Czapskiej, wojewodziny pomorskiej. Opis świątyni i jej wyposażenia, ołtarzy i obrazów, k. 118-120. 
Stan plebanii i pozostałych zabudowań, k. 120-120v.

Protokół wizytacyjny podpisał dnia 3 X 1780 r. Łukasz Jan Krzykowski i Maciej Formela, k. 120v.

Dekret reformacyjny dla parafii Trąbki z dnia $3 \mathrm{X}$ podpisany przez wizytatora Łukasza Jana Krzykowskiego, k. 121.

Pytania i odpowiedzi przy wizytacji parafii Trąbki, sporządzone bardzo dokładnie przez proboszcza Jana Zarembę i podpisane dnia 3 X 1780 r. przez wizytatora Łukasza Jana Krzykowskiego, k. 122-132v.

W y s i n. Wizytacja generalna kościoła parafialnego w Wysinie odbyta w 1870 r., k. 133.

Wykaz tabelaryczny wsi parafialnych położonych w województwie pomorskim i powiecie tczewskim. Wysin miał katolików 225, komunikujących na Wielkanoc 156 i 1 akatolika; Skrzydłowko 56, 31, 28; Skrzydłowo 50, 39, akatolików nie było; Szatarpy 72, 61, akatolików nie było; folwark Łąkie, nie było katolików, 20; Trzepowo, nie było katolików, 86; Piekło Dolne 14, 13, 40; Szumles 38, 29, 75; Szymanowiec 5, 4, 7; Stary Wiec 125, 75, 16; Jełownica 98, 81, akatolików nie było. Ogółem parafia liczyła wiernych 683 osób, komunikujących na Wielkanoc 489, akatolików 273, natomiast Żydów nie było, k. 134.

Świątynia pod wezwaniem Wszystkich Świętych, prawa patronatu biskupa diecezjalnego. Opis położenia parafii. Kościół wymagał naprawy. Wykaz wyposażenia kościoła w paramenty liturgiczne, opis ołtarzy i obrazów. Relikwii nie było. Przywileje odpustowe z racji święta Szkaplerza, bo było tam bractwo tego wezwania. Kaplic publicznych nie było, k. 133-135v.

Opis sprawowania sakramentów, k. 135v-136.

Proboszcz Stanisław Cyprian Wylma, rezydujący na miejscu i należycie spełniający swoje obowiązki. Innych kapłanów, ani zakonników nie było. Krótka charakterystyka stanu moralnego parafian, wśród których nie było żadnych wykroczeń, k. 136-136v.

Stan uposażenia parafii i proboszcza, wykaz mesznego i dochodów oraz rozchodów. Dokładny opis stanu świątyni, zbudowanej na fundamencie kamiennym z drewna. Inwentarz obejmujący spis paramentów liturgicznych. Opis budynków plebańskich i ich inwentarza z ich otaksowaniem. Opis organistówki. Protokół podpisany dnia 5 XI przez Krzykowskiego i Fortel, k. 1236v-138.

Dekret reformacyjny wystawiony przez wizytatora Krzykowskiego w dniu 5 XI 1780 r. i przez niego podpisany, k. 139.

Pytania i odpowiedzi z racji wizytacji, sporządzone przez proboszcza Stanisława Wylma, dnia 5 XI 1780 r., k. 140-147v.

$\mathrm{N}$ i e d a m o w o. Wizytacja generalna kościoła parafialnego w Niedamowie w 1780 r., k. 149.

Wykaz tabelaryczny miejscowości parafialnych parafii Niedomowo, leżących w województwie pomorskim i powiecie tczewskim. Niedamowo katolików3 56, komunikujących na Wielkanoc 26, akatolików 55; Smolniki 12, 9, 20; Dembogóry, gdzie nie było katolików, 75; Honembarg 3, 3, 55; Barembarg, gdzie nie było 
katolików, 12; Stawiska 96, 79. 35; Luboń 90, 41, 80; Wielkie Polesi3 48, 42, 20; Małe Polesie 38, 32, 35. Dawało to ogółem 354 wiernych, z czego do sakramentów wielkanocnych przystępowały 232 osoby. Akatolików mieszkało w parafii 387 osób. Żydów nie było, k. 150.

Świątynia parafialna pod wezwaniem św. Marii Magdaleny. Opis położenia parafii. Stan świątyni w stanie złym. Paramenty liturgiczne, opia ołtarzy i obrazów. Relikwie Krzyża Świętego i inne. Przywileje odpustowe na św. Mikołaja, św. Marii Magdaleny i dla bractwa Różańcowego tu istniejącego, mającego zapis poczyniony przez Annę Klinika, kolatorkę parafii, z 1 I roku 1741, który dokument w języku polskim został tu wpisany. Wspomniany tu został proboszcz niedamowski, Jan Jerzy Pączkowski. Nie było kaplic, szkoły, ani przytułku, k. 151-152.

Sposób sprawowania sakramentów, k. 152-152v.

Proboszcz, a właściwie zarządca parafii, Piotr Piątkowski, tu rezydujący i sprawujący duszpasterstwo. Innych kapłanów, ani zakonników nie było. Poziom moralny parafian dobry, k. $152 \mathrm{v}-153$.

Stan świątyni parafialnej i jej uposażenia. Odpis zapisu Jana Klińskiego, dziedzica z Niedamowa, dla parafii, z dnia 3 I 1725 r. Dokładny opis pozostałych posiadłości parafialnych. Wykaz pobieranego mesznego i wydatków, k. 153-155.

Opis świątyni z drewna zbudowanej, jej wyposażenia w naczynia liturgiczne $\mathrm{i}$ inne paramenty, k. $155-155 \mathrm{v}$.

Stan i opis zabudowań plebańskich, k. 155v. Protokół podpisany przez wizytatora Łukasza Jana Krzykowskiego dnia 11 XI 1780 r., k. 155v-157. $156 \mathrm{v}$.

Dekret reformacyjny z dnia jak wyżej, wystawiony przez wizytatora, k. 156-

Odpowiedzi na pytania wizytacyjne, sporządzone bardzo dokładnie, z podaniem nawet odpisów niektórych dokumentów, przez księdza Piotra Piątkowskiego i przyjęte przez wizytatora 11 XI 1780 r. Odpowiedziano na 337 pytań. Potem opisano kościół w Niedamowie i sporządzono wykaz inwentarza. Na koniec podano wyciag z testamentu Augustyna Klińskiego, sporządzonego w 1750 r., k. 158-176.

R a k o w n i c a. Wizytacja generalna kościoła parafialnego w Rakownicy, odbytej w 1780 r., k. 177.

Wykaz tabelaryczny miejscowości parafialnych położonych w województwie pomorskim i powiecie tczewskim. Rakownica liczyła katolików ogółem 25, komunikujących 18, akatolików 25; Będomino 26, 19, 25; Będominek nie miał katolików, 22; Płoteczno nie miało katolików, 9; Kulmela 4, 4, 9; Papiernia nie miało katolików, 7; Śledziowahuta 2, 2, 12; Jeden dom pewnie stojący na uboczu], gdzie mieszkało 6 akatolików. Parafia ta zatem liczyła ogółem tylko 57 wiernych, z czego do komunii na Wielkanoc przystępowały 33 osoby. Akatolików zaś było 115, natomiast Żydów nie było., k. 178.

Parafia ta z powodu małego dochodu nie posiada własnego proboszcza, stąd od dawna obsługiwana jest przez proboszcza innej parafii w charakterze zarządcy. Dawniej był to proboszcz z Niedamowa, a aktualnie przez proboszcz z Grabowa, dekanatu mirachowskiego. Świątynia pod wezwaniem św. Michała Archanioła, prawa patronatu miejscowych właścicieli. Parafia w województwie pomorskim i po- 
wiecie tczewskim. Stan świątyni średni. Wyposażenie w paramenta liturgiczne i opis ołtarzy i obrazów, k. 179-179v.

Uposażenie kościoła bardzo małe. W kościele tym są nabożeństwa w co trzecią niedzielę. Świątynia z drewna. Spis niewielkiego inwentarza kościelnego, k. 179v.

Protokół podpisany przez wizytatora Łukasza Jana Krzykowskiego w dniu 13 XI 1780 r., k. 180.

G a r c z y n. Wizytacja kościoła parafialnego w Garczynie, w 1780 r. odbyta, k. 181

Wykaz tabelaryczny miejscowości parafialnych w województwie pomorskim i powiecie tczewskim. Garczyn , katolików 51, komunikujących na Wielkanoc 47, akatolików 60; Orle 80, 60, 7; Krtowo, gdzie nie było katolików, 48; Równe, gdzie nie było katolików, 52; Lubieszyn 56, 38, 80; Lubieszynek, gdzie nie było katolików, 12; Liniewo 45, 30, 65; Rukostwo, gdzie nie było katolików, 18; Płachty 27, 19, 1; Liniewko 35, 21, 20; Soboncz 59, 52, 48, Ogólnie więc wiernych były 343 osoby, z czego do sakramentów było zobowiązanych 267 osób. Nie było Żydów, natomiast akatolików naliczono 401 osób, k. 182.

Kościół pod wezwaniem Świętej Trójcy. Opis położenia parafii. Świątynia wymaga naprawy, o czym pamięta kolator i przygotowuje potrzebny materiał. Paramenta liturgiczne wystarczające. Opis ołtarzy i obrazów. Relikwii nie było. Przywileje odpustowe na Świętą Trójcę, św. Andrzeja oraz z racji istniejącego bractwa Bożej Opatrzności, erygowanego w 1766 r. Kaplic publicznych nie było, a tylko prywatna we dworze w Orlu, posiadająca indult, ale własnego kapelana nie było. Szkoły i przytułku nie było, k. 183-183v.

Sposób sprawowania sakramentów, k. 183v-184.

Proboszcz Stanisław Jakub Kaliszewski od 1778 r. i tu rezydujący. Innych kapłanów nie było. Organista niepodanego imienia. Parafianie prości, ale szczerego serca, k. $184-184 \mathrm{v}$.

Uposażenie parafii z wykazem pobieranego mesznego, dochodów i rozchodów, k. $184 \mathrm{v}$.

Opis stanu świątyni, częścią murowanej, częścią w tzw. pruski mur. Spis inwentarza kościelnego oraz stan zabudowań plebańskich. Protokół podpisany przez wizytatora Łukasza Jana Krzykowskiego w dniu 8 XI 1780 r., k. 185-185v.

Dekret reformacyjny spisany przez Wizytatora Łukasza Jana Krzykowskiego, k. 186 .

Odpowiedzi na pytania wizytacyjne, sporządzone bardzo dokładnie przez księdza Stanisława Kaliszewskiego i przyjęte przez wizytatora, k. 188-194.

T c z e w. Wizytacja generalna kościoła parafialnego w Tczewie odbyła w 1780 roku, k. 195.

Świątynia pod wezwaniem Podwyższenia Krzyża Świętego. Kolatorem był król pruski. Opis położenia parafii. Stan kościoła murowanego dobry. Spis paramentów liturgicznych. Opis 12 ołtarzy i obrazów. Relikwii innych nie było, jak tylko cząstka Krzyża Świętego, na co był dokument autentyczności. Liczne przywileje odpustowe. Były kaplice przy kościele, a mianowicie św. Anny, Niepoka- 
lanego Poczęcia NMP., Przemienienia pańskiego, Trzech Króli, św. Apolonii, Opatrzności Bożej i św. Jakuba. Bractwo św. Aniołów Stróżów posiadające własne wyposażenie w paramenty liturgiczne. Kaplic publicznych nie było. Kaplica prywatna w dobrach Stanisławie, bez stałego kapelana, ale podczas wizytacji przebywał tam zakonnik cysters z klasztoru w Pelplinie. Akatolicy w Tczewie mieli swój zbór. Szkoła parafialna, gdzie uczy organista. Przytułek z własnym kościołem, przebywało w nim czterech ubogich żyjących z jałmużny, k. 196-199.

Wykaz tabelaryczny miejscowości parafialnych. Miasto Tczew, gdzie było 508 katolików, komunikujących na Wielkanoc 468noraz 3641 akatolików, Czyżykowo 112, 94, 242; Knybawa 30, 23, 30; Bałdowo 77, 65, 156; Czarlin 33, 29, 18; Rokitki 90, 78, 83; Suchostrzygi 117, 97, 382;mSztembarg 37, 33, 16; Śliwiny 17, 13, 103; Całkowy 28, 20, 164; Lubiszewo, gdzie znajdował się kościół filialny, 130, 104, 12; Stanisławie 90, 76, 26; Rukoszyn 106, 98, 4; Małżewo 71, 37, 8; Małżewko 69, 34, 12; Wytkowy 70, 55, 56; Liniewek 20, 10, 45, Goszyn 68, 55, 35; Swarożyn 104, 98, 58; Zwierzynek 21, 14, 15; Nowy Młyn 23, 16, 26, Pręga 18, 10, akatolików nie było; Michałowo 9, 4, akatolików nie było. Ogólnie zatem parafia ta liczyła katolików 1841, a spowiadających się na Wielkanoc 1531 osób. Więcej znacznie, bo aż 5132 osoby, były wyznania akatolickiego, Żydów natomiast było 200 osób, k. 197.

Sposób sprawowania sakramentów, k. 198v-199.

Proboszcz Franciszek Ignacy de Piechowice Piechowski, kanonik warszawski, mający też kościół filialny w Lubiszewie. Rezydował w Warszawie. Na miejscu pozostawił zakonnika dominikanina Anioła Zawierowskiego, w charakterze zarządcy, sprawującego duszpasterstwo. Przy kościele filialnym rezydował wikariusz Hipolit Basendowski, także dominikanin. Organista Józef Szczodrowski, po śmierci poprzednika Ludwika Diltloff oraz dzwonnik Michał Scijanowski. Przy kościele filialnym znajdował się organista Szymon Trzebicki i dzwonnik Jan Wiśniewski. W Tczewie znajdował się klasztor dominikanów, gdzie przebywało 11 zakonników. Do tego klasztoru była inkorporowana parafia Kokoszkowy w 1653 r. przez biskupa włocławskiego Mikołaja Wojciecha Gniewosza, na co wyraził zgodę król Polski i kapituła włocławska. Proboszczem wówczas został aktualny przeor, Tomasz Frąckiewicz, a potem obowiązki te przechodziły na jego następców. Zakonnicy do duszpasterstwa się nie mieszali. Parafianie nie sprawiali większych kłopotów, k. 199-200v.

Wykaz uposażenia parafii i proboszcza z wyliczeniem pobieranego mesznego. Obliczenie dochodu i rozchodu. Inne dane związane z dochodami i pracami wykonywanymi w parafii, także w kościele filialnym, k. 200v-201v.

Dokładny opis świątyni parafialnej, wykaz sprzętów różnych, a więc wszelkich paramentów liturgicznych, opis 13 ołtarzy i obrazów, k. 202-204v.

Protokół podpisany przez wizytatora Łukasza Jana Krzykowskiego, dnia 7 X 1780 r., k. 204 v.

L u b i s z e w o. Wizytacja kościoła w Lubiszewie, filialnego parafii Tczew. Świątynia pod wezwaniem Świętej Trójcy, prawa patronatu królewskiego, inkorporowana do parafii tczewskiej w 1596 r. przez biskupa włocławskiego Hieroni- 
ma Rozdrażewskiego. Wsie przynależne do tego kościoła: Lubiszewo, Stanisławie, Rukoszyn, Goszyn, Wętkowy, Swarożyn, folwarki zaś: Małżewo, Małżewko, Michałowo, Liniewek, Zabagnie, Zwierzynek, Nowy Młyn, Pręga ${ }^{54}$. Stan świątyni zadowalający i jej opis. Opis paramentów liturgicznych, trzech ołtarzy i obrazów. Relikwie św. Józefa [?]. Przywileje odpustowe na Świętą Trójcę i Wniebowzięcia NMP. Przy kościele kaplica św. Antoniego z Padwy. Bractwo Opatrzności Bożej. Porządek nabożeństw, k. 205-206.

Opis świątyni murowanej. Wykaz paramentów liturgicznych, k. 206-208.

Protokół podpisany w Lubiszewie dnia 7 X przez wizytatora Krzykowskiego, k, 208-208v.

Dekret reformacyjny dla parafii Tczew i kościoła filialnego w Lubiszewie podpisany 7 X przez wizytatora Krzykowskiego, k. 209.

Odpowiedzi na pytania dotyczące parafii tczewskiej sporządzone przez Anioła Zawierowskiego i przyjęte przez wizytatora Łukasza Krzykowskiego 7 X 1780 r. Wśród tych odpowiedzi znajduje się też zestawienie tabelaryczne, zgodne z tym w samym protokole. Odpowiedzi dotyczyły 328 pytań. Nie pominięto wyliczenia, co w sprawach materialnych uczyniono w ostatnim czasie staraniem proboszcza i zarządzającego aktualnie parafią, w tym także przy kościele w Lubiszewie. Sporządzono ty także w języku polskim dokładny opis świątyni parafialnej. Przyjął to i potwierdził 7 X wizytator Łukasz Jan Krzykowski, k. 210-232v.

Odpowiedzi na pytania dotyczące kościoła filialnego w Lubiszewie, sporządzone przez wikariusza lubiszewskiego Hipolita Bassendowskiego i przyjęte w dniu 7 X 1780 r. przez wizytatora Łukasza Jana Krzykowskiego, k. 233-243v.

$\mathrm{S} t$ a r o g a $\mathrm{r}$ d. Wizytacja generalna dekanatu starogardzkiego w diecezji pomorskiej w 1780 r., k. 244.

Krótka charakterystyka dekanatu, którego dziekanembył Jan Bastkowski, zdnia 15 IX 1780 r., podpisana przez wizytatora, k. 245-245v.

Odpowiedzi na 35 pytań wizytacyjnych, udzielone przez dziekana starogardzkiego i przyjęte 15 IX 1780 r. przez wizytatora, Łukasza Jana Krzykowskiego, k. $247-247 \mathrm{v}$.

$\mathrm{S}$ t a r o g a r d. Wizytacja generalna kościoła parafialnego prepozyturalnego w Starogardzie w roku 1780 przeprowadzona, k. $350^{\text {as5 }}$.

Kościół w mieście (civitas) Starogard, pod wezwaniem św. Mateusza Apostoła, murowany, którego kolatorem był król pruski. Opis położenia parafii w stosunku do innych sąsiednich parafii i do ośrodków diecezjalnych. Świątynia wymagała napraw. Zakrystia wyposażona w potrzebne sprzęty. Opis ołtarzy, których było jedenaście i obrazów. Swiątynia miała relikwiarz z relikwiami różnych świętych, ale bez dokumentów autentyczności. Był natomiast zapis z 1660 r., wykonany przez ówczesnego proboszcza i dziekana starogardzkiego, mówiący, że relikwiarz ten, w formie krzyża, podczas wojen szwedzkich został schowany w ziemi, gdzie

\footnotetext{
${ }^{54}$ Wsie te były wymienione w spisie tabelarycznym parafii tczewskiej.

${ }^{55}$ Ten początek protokołu wizytacyjnego umieszczono przez pomyłkę sto kart dalej.
} 
przeleżał lat pięć, co spowodowało zniszczenie znajdujących się na nim zapisów. Dawniej w Starogardzie były trzy prebendy z własnym uposażeniem, a więc kościółek przy bramie gdańskiej pod wezwaniem Matki Boskiej, a także św. Jakuba i św. Katarzyny, ale teraz pozostało po nim jedynie plac. Na przedmieściu były jeszcze: przy bramie gdańskiej kościółek Świętego Ducha, a także kościółek św. Jerzego, po którym pozostały ruiny. Poza miastem także był niegdyś kościółek pod wezwaniem św. Jana Chrzciciela, posiadający na uposażenie cztery łany ziemi. Teraz po tym wszystkim nic nie pozostało. Przy kościele tym było bractwo Różańcowe, posiadające dokument zaprowadzenia, ale bez własnego uposażenia, czyli utrzymujące się jedynie z ofiar. Jednakże opiekowało się ołtarzem Najświętszej Marii Panny, wystawionym kosztem Józefa Grąbczewskiego, kasztelana chełmińskiego ${ }^{56} . \mathrm{k} \cdot 350^{\mathrm{b}}$. Bractwo to miała swoje paramenty liturgiczne, obrazy do noszenia w procesji. Ponadto istniało też bractwo św.. Barbary. Kaplic publicznych nie było, a kaplica prywatna we wsi Rękoczyn, ale bez własnego kapelana. Na miejscu dawnej kaplicy św. Katarzyny, teraz V akatolicy swój zbór. Żydzi posiadają swoją szkołę w domu prywatnym. Zakonów żadnych nie było. Szkoły jako takiej nie było, ale uczył Wawrzyniec Zdanowski. Uczył, ale tylko w zimie, około 20 dzieci obojga płci. Szpital za miastem, a przy nim kaplica pod wezwaniem św. Jerzego, posiadający pewne uposażenie, k. 250-250v.

Wykaz tabelaryczny miejscowości parafialnych ${ }^{57}$, położonych w Prusach, województwie pomorskim i powiecie tczewskim: Miasto Starogard liczyło ogółem katolików 900, komunikujących na Wielkanoc 700, akatolików 800 i 120 Żydów; Kuczborowo odpowiednio 44, 24, -, -; Kolincz 50, 32, 10, 12; Barchnowy 74, 48, 4, -; Jabłowo 60, 49, 4, -; Owidz 56, 49, 14, -; Rękoczyn 89, 62, 6, -; Kołyże, Treda i Płaczewo 33, 17, 49, -; Sumin z dodatkami Józefowo, Brzeziny i Wygoda 125, 81, 47, -; Nowawieś 97, 72, 8, -, k. 249.

Sposób sprawowania sakramentów, k. 250v-251.

Proboszcz Jan Bastkowski liczący lat 49, prepozyt i dziekan starogardzki, w parafii rezydujący. Wikariusz Michał Politowski, lat $32 \mathrm{w}$ charakterze zarządcy. W parafii był także brat proboszcza, zakonnik z Nowego, Mikołaj Bastkowski, wspomagający do w duszpasterstwie, za ci daje wynagrodzenie dla macierzystego klasztoru. Organista Jan Radziecki, kościelny Wawrzyniec Zdanowski, dzwonnik Paweł Sakowski. Zakonników żadnych nie było. Opis stanu moralnego parafian, k. $251 \mathrm{v}-252$.

Opis stanu uposażenia parafii i proboszcza, dosyć dokładny, z podaniem dochodów i rozchodów. Odpis zapisu poczynionego na sumę rocznego dochodu piętnaście złotych, poczynionego 2 XI 1768 r., przez Adama Pałubickiego, administratora starostwa gorzewskiego, co zatwierdził Cyprian z Komorza Wolicki, sufragan pomorski i wikariusz in spiritualibus oraz oficjał generalny, w Gdańsku, dnia 19 XI 1768 r., k. 252-253v.

${ }^{56}$ Protokół ten nie ma zakończenia. Po nim następują karty z wyżej podanymi odpowiedziami o kościele w Zblewie.

${ }^{57}$ Nie ma strony tytułowej rozpoczęcia wizytacji tej parafii, a nawet karty początkowej opisu, ponieważ karta 250 zawiera ciąg dalszy protokołu. 
Opis dokładny świątyni w Starogardzie, z wyliczeniem inwentarza kościelnego, opis zabudowań plebańskich i ich sprzętów, k. 253v-254v.

J a b ł o w o. Opis kościoła filialnego w Jabłowie. Świątynia z pruskiego muru, pod wezwaniem św. Wawrzyńca. Opis tego kościoła z podaniem wyposażenia, dosyć skromnego. Zabudowania, a więc plebania, stodoła, owczarnia wyremontowane przez proboszcza, w stanie dobrym, ale bez inwentarza, k. 255.

$\mathrm{N}$ o w a W i e ś. Opis kościoła filialnego w Nowej Wsi. Świątynia pod wezwaniem św., Anny, drewniana, ale ze starości znacznie zniszczona, Wykaz skromnego wyposażenia. Zabudowań plebańskich nie ma, ale na gruncie wybudowało się dwóch dzierżawców płacących proboszczowi dzierżawę z ziemi zajmowanej, k. 255-255v.

Protokół powizytacyjny, podpisany w Starogardzie dnia 15 IX 1780 r. przez wizytatora Łukasza Jana Krzykowskiego i sekretarza Macieja Formela, k. 255v.

Dekret reformacyjny dla parafii starogardzkiej i kościołów filialnych w Jabłowie i Nowejwsi, z dnia 15 IX 1780 r., wystawiony przez wizytatora Łukasza Jana Krzykowskiego, k. 256-256v.

Odpowiedzi na stawiane podczas wizytacji pytania, których było 328, spisane przez zarządcę parafii Michała Politowskiego, dnia 15 IX 1780 r. Ponadto zamieszczono tu także opis budynków plebańskich w Starogardzie i Jabłkowie oraz krótkie opisy kościołów w Jabłkowie i Nowej Wsi. Ta odpowiedź przyjęta i podpisana przez wizytatora Łukasza Jana Krzykowskiego, k. 257-279.

K o k o s z k o w y. Wizytacja generalna kościoła parafialnego w Kokoszkowach, przeprowadzona w 1780 r., k. 280.

Świątynia pod wezwaniem św. Barbary, zbudowana z kamienia polnego. Prawo patronatu należało do monarchy pruskiego. Opis położenia parafii. Stan świątyni i jej wyposażenie, ołtarze i obrazy. Relikwii żadnych nie było. Odpust na św. Barbarę, głównie z racji bractwa Jej imienia. We wsi Szpęgawsk, gdzie dawniej znajdowała się świątynia parafialna, we dworze aktualnie była kaplica prywatna, posiadająca odpowiedni indult, o który starał się Wincenty Bystram, podkomorzy królewski, z potrzebnymi paramentami do mszy, a kapelanem był zakonnik paulin. W dni świąteczne jednak on udaje się albo do parafii, albo częściej do Starogarda, gdzie służy pomocą w konfesjonale. Na terenie parafii byli akatolicy. Nie było Żydów. Szkoły nie było, a jedynie organista w porze zimowej uczył dzieci. Przytułek z czterema podopiecznymi żyjącymi z jałmużny, k. 281-283v.

Wykaz tabelaryczny wsi parafialnych. Kokoszkowy, gdzie katolików ogółem było 98, komunikujących na Wielkanoc 74, zaś akatolików 14; Linowiec 58, 47, 17; Żabno z dodatkami 24, 19, 33; Szpęgawsk 114, 98, 7; Zduny 34, 27, 4; Ciecholewy 64, 52, 17; Bączek z dodatkami 47, 39, 8; Krag z dodatkami 25, 18, 57. Ogółem więc było w parafii 464 wiernych, w trym komunikujących na Wielkanoc 374 osoby. Ponadto na Terenia parafii zamieszkiwało 157 akatolików, k. 282.

Sposób sprawowania sakramentów $283 \mathrm{v}-284 \mathrm{v}$. 
Parafia ta jest inkorporowana do konwentu dominikanów w Tczewie na mocy zarządzenia biskupa włocławskiego Wojciecha Gniewosza. Dlatego proboszczem jest przeor tegoż konwentu. Aktualnie jest nim Bonifacy Klugocki, magister św. Teologii, rezydujący przy klasztorze. Parafią zarządzał Kazimierz Sciankowski, rezydujący na miejscu i sprawujący duszpasterstwo. Organista i dzwonnik Wawrzyniec Szczodrowski. Klasztoru i zakonników na terenie parafii nie było. Charakterystyka parafian, nie sprawiających większych trudności, k. 284v-285v.

Opis uposażenia beneficjum. Odpis zapisu 700 florenów dokonanego przez Stanisława Konarskiego, co potwierdził jego syn Ignacy Konarski dnia 5 VI $1771 \mathrm{r}$. Wykaz dochodów, także z pobieranego mesznego oraz wydatków, k. 285c-286v.

K o k o s z k o w y. Opis dokładny świątyni parafialnej w Kokoszkowach, od najdawniejszych czasów inkorporowanej do konwentu dominikanów w Tczewie, murowanej, z polnych kamieni. Świątynia posiadała trzy ołtarze. Było kilka obrazów. Zapewne było bractwo różańcowe, jeżeli były obrazy do tego bractwa należące. Inwentarz rzeczy świętych, czyli naczyń liturgicznych i innych paramentów, dosyć bogatych i licznych. Wykaz zabudowań plebańskich oraz inwentarza gospodarczego, żywego i martwego, k. 287-289.

Protokół podpisał dnia $13 \mathrm{X}$ wizytator Łukasz Jan Krzykowski i sekretarz Maciej Formela, k. 1289v.

Dekret reformacyjny dla parafii Kokoszkowy wystawiony 13pażdziernika 1780 r. przez wizytatora Łukasza Jana Krzykowskiego, k. 290.

Odpowiedzi na pytania wizytacyjne postawione przy wizytacji kościoła parafialnego w Kokoszkowach, pokrywające się w zasadzie z protokołem, przynajmniej w pewnych częściach, sporządzone przez zarządcę Kazimierza Sciankowskiego i przyjęte przez wizytatora w dniu 13 X 1780 r., k. 291-299v.

K 1 o n ó w k a. Wizytacja generalna kościoła parafialnego w Klonówce, odbyta w 1780 r., k. 300.

Świątynia pod wezwaniem św. Katarzyny, murowana, której kolatorem był Jerzy Kalkszteyn, dziedzic dóbr Klonówka. Opis położenia parafii e województwie pomorskim i powiecie tczewskim. Stan świątyni i jej wyposażenia. Cztery ołtarze, ich opis, a także obrazów. Było wiele różnych relikwii. Przywilej odpustowy na uroczystość św. Katarzyny. Prebend, ani kaplic nie było. Bractwo Różańcowe zaprowadzone w 1732 r. przez dominikanów, mające nawet pewien zapis, a także swoje paramenta liturgiczne. Kaplica prywatna we wsi Nowy Dwór, przy której zawsze przebywała kapłan zakonnik z klasztoru w Pelplinie, ponieważ wieś ta należała do opactwa. Był indult na sprawowanie tam mszy, ale nie wchodziło to w kolizje z prawem parafialnym. Szkoły nie było, a jedynie w porze zimowej nauczyciel uczył jedynie we Klonówce. Przytułku z własną kaplica nie było, a jedynie w Klonówce dom, zapisany testamentem przez niejaką Mariannę Pawłowska, o dwóch izbach, z których jedną zamieszkiwał nauczyciel, a w drugiej mieszkało dwóch ubogich żyjących z jałmużny, k. 301-303.

Wykaz tabelaryczny wsi parafialnych. Klonówka, gdzie było 194 katolików, z których komunikowało na Wielkanoc 141, akatolików i Zydów nie było; Naj- 
muzy folwark, 17, 17, 6 akatolików; Mosty 19, 12, akatolików w nie było, a Żydów około 60; Marywill 22. 20, 3, Żydów nie było; Rywałdt 155, 115, 6, Żydów nie było; Nowy Dwór, 144, 98, akatolików i żydów nie było; Lipienki 1, 1, 17, Żydów nie było. Parafia liczyła więc wszystkich wiernych 552, w tym komunikujących na Wielkanoc 399. na terenie parafii mieszkali także akatolicy w liczbie 32 osoby oraz Żydzi, których było 60 osób, k. 302.

Sposób sprawowania sakramentów, k. 303-303v.

Zarządca parafii był Maciej Praczkowski. Opis sprawowanych nabożeństw. Organista Marcin Paszkowski. Na terenie parafii, przy kaplicy we wsi Nowy Dwór, przebywał Konstanty Preyszoft, zakonnik cysterski. Innych kapłanów nie było. Krótka charakterystyka parafian, k. 303v-304v.

Uposażenie proboszcza. Odpis dokumentu zapisu czterech włók ziemi dla proboszcza, uczyniony w 1719 r. przez Mariannę Wolffów Kossowa, wojewodzinę chełmińską. Dalszy wykaz pobieranego mesznego, a także wydatków, k. 304v305.

Dokładny opis świątyni w Klonówce, wykaz inwentarza, a więc naczyń srebrnychi innych sprzętów i paramentów kościelnych. Stan plebanii wystawionej w 1780 r., a więc dobrej oraz wykaz inwentarza gospodarczego, żywego i martwego. Protokół podpisał 11 X 1780 r. wizytator Krzykowski, k. 305v-308.

Dekret reformacyjny dla parafii w Klonówce, wystawiony przez wizytatora Łukasza Jana Krzykowskiego, dnia 11 X 1780 r., k. $307^{58}$.

Odpowiedzi na pytania wizytacyjne, dokładniejsze nawet aniżeli sam protokół, sporządzone przez zarządcę Macieja Praczkowskiego i przyjęte przez wizytatora w dniu 11 X 1780 r., k. 309-321.

B o b o w o. Wizytacja kościoła parafialnego we wsi Bobowo, odbytej w 1780 roku, k. $322^{59}$.

Nazwa niemiecka tej miejscowości to Bobau. Świątynia pod wezwaniem św. Wojciecha. Prawo patronatu należało do monarchy pruskiego. Opis położenia parafii w województwie pomorskim i powiecie starogardzkim. Stan świątyni średni. Jej opis. Paramenty liturgiczne i opis trzech ołtarzy i obrazów. Relikwii żadnych nie było. Przywileje odpustowe z racji święta św. Wojciecha. Osobnych prebend i beneficjów nie było. Bractwo Różańcowe założone w 1706 r. przez dominikanów, co potwierdził w roku w 1719 r. oficjał gdański Andrzej Góra. Kaplic nie było. Była szkoła rządowa. Przytułek, do którego należał jeden ogród, przeznaczony był dla czterech podopiecznych starych, niemogących już pracować. Opiekował się nimi Proboszcz, zaś utrzymywali się z pomocy pobożnych parafian, k.323-325.

Wykaz tabelaryczny wsi parafialnych, Na terenie parafii nie było Żydów. Bobowo liczące 331 katolików, z czego spowiadało się na Wielkanoc 232 osoby oraz było 6 akatolików; Wysoka 208, 159 i 4, Dąbrówka 157, 116, 38; Zawionki 15, 14, 1; Smoląk folwark 50, 35, akatolików nie było; Grabowiec gdzie mieszkało

\footnotetext{
${ }^{58}$ Karta z dekretem reformacyjnym wklejona później, stąd pewna niezgodność w paginacji..

${ }^{59}$ Protokół ten spisany inna ręką, chociaż podpisał go także sekretarz Formela.
} 
jedynie 8 akatolików; Rusek, 3, 2, ale akatolików też nie było. W sumie, więc parafia liczyła 76e wiernych, komunikujących na Wielkanoc było 558. Akatolików mieszkało 57, natomiast Żydów nie było, k.324.

Sposób sprawowania sakramentów, k. 325-325v.

Proboszcz Józef Reynerowski, naznaczony przez króla, ale niemający zatwierdzenia przez ordynariusza, a jedynie przez oficjała miał zlecony zarząd parafią. Rezydował na miejscu i należycie sprawował duszpasterstwo, tu dokładnie opisane. Nie było w parafii żadnego klasztoru. Organista Michał Witkowski. Witrykusi Antoni Szkodowski i Maciej Chojnacki. Stan moralny parafian nie budził zastrzeżeń, k. 326-326v.

Opis uposażenia beneficjum z podaniem dochodów, w tym także z filialnego kościoła w Dąbrówce, a także rozchodów. Podano też dochód organisty. Nie było specjalnego funduszu na naprawy świątyni i ciężar ten spoczywał na parafianach, ale ci byli biedni, k. 326v-327.

Opis kościoła w Bobowie i jego wyposażenie w naczynia liturgiczne i inne rzeczy tu wyszczególnione. Inwentarz bractwa różańcowego. Opis stanu zabudowań plebańskich i wykaz inwentarza gospodarczego, żywego i martwego, k. 327-329.

D ąb ró w ka. Wizytacja kościoła filialnego parafii Bobowo w Dąbrówce, z kościołem Podwyższenia Krzyża Świętego. Prawo patronatu należało do monarchy pruskiego. Stan świątyni dosyć dobry, tu opisany. Wyposażenie w paramenty liturgiczne wystarczające. Opis trzech ołtarzy i obrazów. Obrazu słynącego łaskami nie było, Nie było także relikwii, a odpust na święto Podwyższenia Krzyża. W świątyni tej przechowywano Najświętszy Sakrament w tabernakulum należycie urządzonym Inne sakramenty opisano przy kościele parafialnym, jak wyżej. Opis świątyni murowanej, pochodzącej, jak wieść niosła, z czasów krzyżackich. Wykaz inwentarza tego kościoła, a więc paramentów liturgicznych, k. 329-332.

Protokół wizytacji parafii Bobowo i kościoła filialnego w Dąbrówce podpisał wizytator Łukasz Jan Krzykowski w dniu 15 X 1780 r., k. $331^{60}$.

Dekret reformacyjny także z dnia jak wyżej, wystawiony i podpisany przesz wizytatora Łukasza Jana Krzykowskiego, k. 331.

Odpowiedzi na napytania postawione przy wizytacji parafii w Bobowie oraz z racji wizytacji kościoła filialnego w Dąbrówce, właściwie zgadzające się z protokołem wizytacji, spisane przez zarządcę Józefa Reynerowskiego i przyjęte przez wizytatora w dniu 15 X 1780 r., k. 333-340v,

Z b l e w o. Wizytacja generalna kościoła parafialnego w Zblewie, przeprowadzona w 1780 r., k. 341.

Nazwa niemiecka nazwa miejscowości - Szteblau. Świątynia pod wezwaniem św. Michała Archanioła, prawa patronatu królewskiego, w archidiakonacie, oficjałacie i województwie pomorskim, w powiecie tczewskim w Prusach. Położenie w stosunku do najważniejszych miejscowości diecezji włocławskiej. Kościół zbudowany z pruskiego muru. Stan zachowania świątyni średni. Zakrystia murowa-

\footnotetext{
${ }^{60}$ Karta ta została wklejona później.
} 
na. Dzwonnica drewniana z potrzebnym wyposażeniem. Opis czterech ołtarzy i obrazów. Relikwii żadnych nie było. Nie było prebend ani kaplic. Arcybractwo Różańcowe, bractwo Najświętszego Imienia Jezus i Matki Boskiej, za aprobata Stolicy Apostolskiej w 1732 r. Opis funkcjonowania tych bractw i ich uposażenia. Kaplica prywatna w dworze Feliksa Plaskowskiego, za zezwoleniem władzy diecezjalnej. Kapelan Grzegorz Wilhelm. Nie było naruszenia praw parafialnych. Szkoła parafialna, gdzie uczył katolik Jakub Lege, wynagradzany przez rząd, ale dzieci uczyły się jedynie zimą. Przytułku nie było, k. 341-344.

Wykaz tabelaryczny wsi parafialnych. Żydów było jedynie 4 osoby we wsi Piece Iwickie. Zblewo, liczące katolików 122, w tym komunikujących na Wielkanoc 104 oraz 11 akatolików; Borzechowo 142, 118, 14; Bytonia 96, 80, akatolików nie było; Iwiczno 65, 56, akatolików nie było; Piece Iwickie 64, 48, akatolików wnie było, Żydów 4; Huta Czubkowa 16, 12, 49; Nowa Karczma gdzie było jedynie 5 akatolików; Krzewina 16, 15, akatolików nie było; Kaliska Kiszewskie 39, 26, akatolików nie było; Ciss 9, 6, akatolików nie było; Nierasowo z dodatkami, 78, 60, 38; Blomfeldt 79, 62, 51; Czarne i Czubek 18, 15, akatolików nie było; Trzechowo 10, 6, 3; Radziejewo 54, 41, 19, Białachowo 10, 6, 6; Bukowiec 22, 16, akatolików nie było; Łubiki 9, 6, akatolików nie było; Młyńsk 30, 20, 1; Łążek 4, 3, 5; Libichowo110, 92, 20;Pszowo 43, 38, 30; Ocepel 3o, 20, 3; Zielona Góra 40, 35, 15; Mościska jedynie 30 akatolików; Połom 3, 3, 3; Lipianki 2, 2, 6; Pazda 5, 3, 8; Bietowo 70, 68, 19; Stwelkno 70, 68, 19; Krępka 13, 10, 4; Młynki 18, 14, 5; Bilizebłota ${ }^{61}$ 10, 9, 30; Budy 25, 18, 1 . Ogółem było więc w parafii 1273 wiernych, z czego spowiadających się na Wielkanoc naliczono 1025 osób. Ponadto na terenie parafii mieszkało 391 akatolików oraz 4 Żydów, k. 343.

Sposób sprawowania sakramentów, k. 344-344v.

Proboszcz Tomasz Józef Łyszkowski. Obowiązki swoje sprawował należycie, tak co do nabożeństw, jak i prowadzonych ksiagg parafialnych. Wikariusz Jan Bąkowski. Witrykusi Wojciech Orlikowski i Jakub Prabucki oraz nauczyciel, który spełniał też obowiązki dzwonnika. Był też niepodanego nazwiska organista. Nie było żadnych zakonników. Opis stanu moralnego parafian, k. 344v-345v.

Opis uposażenia proboszcza i parafii, $\mathrm{z}$ wyliczeniem oddawanego mesznego według poszczególnych wsi oraz wydatków. k. 345v-346v.

Opis dokładny świątyni oraz jej wyposażenia w paramenty liturgiczne, $\mathrm{k}$. $346 \mathrm{v}-347 \mathrm{v}$.

Opis zabudowań plebańskich oraz inwentarza gospodarczego, k. 347v-348.

L u b i c h o w o. Opis kościoła Lubichowskiego, złączonego od dawna z kościołem Zblewskim. Świątynia drewniana, pod dachówką. Dokładny jej opis, a także wyposażenia. Nabożeństwa w co trzecią niedzielę. Wykaz inwentarza kościelnego, a więc naczyń liturgicznych i pozostałych paramentów. Były zabudowania plebańskie, z których proboszcz pobierał dzierżawę, k. 348v-349v.

${ }^{61}$ Niektóre nazwy miejscowości nieczytelne z powodu uszkodzenia mechanicznego tabeli. 
Protokół wizytacji parafii Zblewo ${ }^{62}$, z dnia 17 IX 1780 r., podpisany przez wizytatora Łukasza Jana Krzykowskiego i sekretarza Macieja Formela, k. 349v.

Dekret reformacyjny dla parafii Zblewo i kościoła filialnego w Lubichowie, wystawiony przez wizytatora Łukasza Krzykowskiego, k. 350.

$\mathrm{Na}$ kartach $350^{\mathrm{a}}$ i $350^{\mathrm{b}}$ wklejono początkowe karty protokołu wizytacyjnego parafii prepozyturalnej Starogard.

Odpowiedzi na pytania z racji wizytacji kościoła parafialnego w Zblewie i kościoła w Libichowie, których było ogółem 328, sporządzony przez księdza Tomasza Łyszkowskiego k. 351-365v.

Opis kościoła parafialnego w Zblewie i jego wyposażenia, też sporządzony przez księdza Tomasza Łyszkowskiwego, k. 366-370.

Opis Kocioła lubichowskiego, złączonego z parafią Zblewo, sporządzony także przez księdza Tomasza Łyszkowskiego, k. 370-377v ${ }^{63}$.

C z e r s k. Wizytacja generalna kościoła parafialnego w Czersku, przeprowadzona w1781 r., k. 378.

Wieś ze świątynią pod wezwaniem św. Marii Magdaleny, patronatu królewskiego. Opis położenia, także w odniesieniu do centrów diecezjalnych. Dawniejsza świątynia, niewiadomo przez kogo fundowana, po pożarze w 1754 r., od nowa zbudowana w 1762 r., w 1767 r. konsekrowana przez bpa Cypriana Wolickiego. Opis dokładny tego kościoła, drewnianego i pod dachówka, z dzwonnica doń przylegającą. Zakrystia drewniana odpowiednio urządzona. Opis ołtarzy, których było siedem oraz znajdujących się tu obrazów, k. 379-379v.

Wykaz tabelaryczny wsi parafialnych z podaniem liczby mieszkańców. Żydów było 4, a mianowicie dwóch w miejscowości Lutom i $2 \mathrm{w}$ Brusach. I tak Czersk z dodatkami liczył 377 katolików, w tym komunikujących na Wielkanoc 299 oraz 29 akatolików; Legmont 146, 123, akatolików nie było, Lutom z dodatkami 54, 31, 8; Zapendowo 45, 30, 6; Malechin 76, 50, 20; Mokre z dodatkami 102, 62, 43; Niezorawa z dodatkami 90, 70, 18; Retel z dodatkami 197, 138, 10; Łag z dodatkami 307, 226, 8; Będźmierowice z dodatkami 90, 60, 31; Brusy 59, 30, 14; Klepiny z dodatkami 116, 84, akatolików nie było, Gottheltt 30, 15, akatolików nie było; Zawada z dodatkami 63, 33, akatolików nie było. Ogólna statystyka parafii podaje zatem 1760 wiernych, z czego do Komunii przystępowało 1259 osób. Katolików mieszkało 107, a Żydów 4 osoby, k. 380.

Wykaz wszelkich paramentów kościelnych. Relikwii nie było. Wyliczenie przywilejów odpustowych. Żadnych prebend i beneficjów też nie było. Bractwo św. Jana Nepomucena założone z przywileju Stolicy Apostolskiej w 1741 r., ale nie posiada swoich statutów. Utrzymuje się z ofiar. Promotorem jest Proboszcz. We wsi Mokre, dziedzicznej Michała Pawłowskiego, jest kaplica publiczna, wystarczająco wyposażona w paramenty liturgiczne. Kapelanem był Konstanty Wy-

\footnotetext{
${ }^{62} \mathrm{~W}$ tekście wyraźny znak poprawki.

${ }^{63}$ Powyższe odpowiedzi na pytania i opisy świątyń i parafii Zblewo i Lubichowo są umieszczone po karcie rozpoczynającej opis kościoła w Starogardzie, stad niezgodność kolejności kart. Karta 350 b powinna znaleźć się na swoim miejscu, to jest po tabeli na karcie 249. tam też na swoim miejscu jest umieszczona treść tej karty 350 .
} 
socki. Było wielu akatolików, ale nie posiadali swojego zboru i chowali się oni obok cmentarza parafialnego. Szkoły ani przytułku nie było, k. 381-382.

Sposób sprawowania sakramentów, k. 382-382v.

Proboszcz Andrzej Miszewski. Innego beneficjum nie posiadał. Wikariusz Józef Dołęgowski. Organista i kościelny w jednej os0bie nosił nazwisko Franciszek Pałucki. Nie było żadnych zakonników. Poziom moralny parafian normalny. Nie było publicznych grzeszników, k. 382v-383.

Opis uposażenia proboszcza. Wykaz dokładny pobieranego mesznego z poszczególnych wsi, oraz dochody i rozchody. Dokładny opis stanu zabudowań plebańskich, także gospodarczych. Wykaz ilości wysianego zboża oraz inwentarza żywego i martwego, k. 383-384.

Ł ę g. Wizytacja kościoła filialnego w Łęgu. Świątynia pod wezwaniem Narodzenia Najświętszej Marii Panny i jej położenie. Jest to świątynia drewniana, miejscami potrzebująca naprawy. Opis sprzętów w niej się znajdujących. Trzy ołtarze i ich opis. Wykaz paramentów liturgicznych, ornatów, bielizny, argentariów i innych. Bractwo Różańcowe w 1757 r. zaprowadzone. Jego kapelanem był Proboszcz. Nie posiadało własnego funduszu, ani zapisów. Do tego kościoła należały cztery łany ziemi. Znajdowały się tu też zabudowania, dosyć dokładnie opisane, k.385-386v.

Protokół podpisany przez wizytatora Łukasza Jana Krzykowskiego w dniu 30 X 1781 r., k. 386v.

Dekret reformacyjny dla parafii Czersk z dnia 30 X 1781 r., też przez wizytatora Łukasza Jana Krzykowskiego wystawiony i podpisany, k. 387.

Odpowiedzi na pytania postawione z racji wizytacji kościoła parafialnego w Czersku, i kościoła filialnego w Łęgu, sporządzony przez proboszcza Andrzeja Miszewskiego i potwierdzony przez wizytatora Łukasza Jana Krzykowskiego, tego samego dnia, co i samej wizytacji. Te „odpowiedzi” sporządzone na sposób protokołu wizytacyjnego i z nim zgodny, k. 388-401v. k. 402 .

K i s z e w a. Wizytacja kościoła parafialnego w Kiszewie, odbyta w 1780 r.,

Wykaz tabelaryczny wsi należących do parafii Kiszewa. W parafii nie było Żydów. Stara Kiszewa liczyła 141 katolików, z czego spowiadało się na Wielkanoc 125 osób oraz akatolików 20; Zamkowa Kiszewa, 139, 123, 23; Nowa Kiszewa 5, 5, 109; Bartoszów Las 31, 28, 38; Konarzyny 89, 80, 39; Olpuch 36, 31, -; Barthel 46, 39, 6; Studzienice 23, 20,-; Huta 24, 20, 15; Maliki Górne 25, 20 8; Strzelki 1, 1, 12; Wygonin 34, 29,-; Uroża 20, 19, 11; Ruda 19, 17, 6; Cięgardło 19, 17, -; Barłogi 11, 10, -; Tyszarstwo i Gołub 20, 18, -; Nierybno 22, 19, 9; Struga tylko 6 akatolików; Dubrek i Cieciorka 2, 2, 12; Kamiona i Ludwiki Dolne 6, 6, -; Pałubin 2, 2, 90; Chwarzcienko, Foss, Huta i Szuflane 71, 60, 48; Boże Pole 38, 30, 10; Chwarzno 72, 60, 45; Bukowiec Stary z przyległościami 15, 10, 47; Bukowiec nowy z przyległościami 28, 24, 38. Zatem ogółem parafia liczyła 939 katolików i 590 akatolików, k. 403. 
Świątynia parafialna pod wezwaniem św. Marcina, prawa patronatu monarszego. Opis położenia w stosunku do najważniejszych ośrodków diecezjalnych. Ponieważ stara świątynia popadła w ruinę, wystawiono nową, na nowym miejscu, staraniem Stanisława i Katarzyny Skórzewskich, starostwa kiszewskiego i parafian w 1742 r., konsekrowana za pozwoleniem miejscowego ordynariusza przez sufragana chełmińskiego Fabiana Pląskowskiego w 1759 r. Stara zaś świątynia rozebrana z polecenia Augustyna Klińskiego, wizytatora i z odzyskanego drewna wystawiono kaplicę pod wezwaniem św. Barbary, k. 404.

Opis świątyni znajdującym się w dobrym stanie. Trzy ołtarze. Relikwii nie było. Nie było także żadnych prebend, ani osobnych beneficjów. Nie było żądnego bractwa, ale aktualny proboszcz przygotował wszystko, aby mogło zostać erygowane bractwo Szkaplerza, i datę erekcji przełożono na następny rok. Było Droga Krzyżowa i przywilejem odpustowym. Kaplica św. Barbary, o której wyżej. Nie było kaplic prywatnych. Mieszkający na terenie parafii akatolicy mieli swoje cmentarze w Nowej Kiszewie i tamże szkołę oraz cmentarz we wsi Bartoszów Las, k. 404-404v.

Sposób sprawowania sakramentów, k. 404v-405.

Proboszcz Andrzej Józef Schulz, dziekan tczewski, osobiście spełniający obowiązki duszpasterskie. Jego wikariusz, Jan Tendycki odszedł na probostwo do Pinczyna, i proboszcz Schulz oczekuje na jego następcę. Organista Marcin Bławat. Żadnych zakonników nie było. Stan moralny parafian nie budził większych zastrzeżeń, k. 405-405v.

Opis uposażenia probostwa. Wykaz pobieranej dziesięciny snopowej według miejscowości. Wykaz wydatków. Także organista miał prawo pobierania opłat z parafii oraz a niektórych wsi dziesięcinę snopową, zwana „taxa”, k. 406-407.

Dokładny opis świątyni drewnianej, na fundamencie murowanym, w stanie dobrym, z murowanym z kamienia grobowcem i herbem Skórzewskich. Opis sprzętów wyposażenia świątyni. Inwentarz paramentów liturgicznych, k. 407-407v.

Stan zabudowań plebańskich i ich dokładny opis. Spis inwentarza żywego i martwego, k. 408.

Po 1 a s z k i. Opis świątyni w Polaszkach, od dawna przyłączonego do parafii Kiszewa. Świątynia murowana, kryta dachówką. Opis wnętrza świątyni z czterema ołtarzami. Zakrystia także murowana. Do kościoła tego należy praktycznie jedynie wieś Polaszki. Kolatorami tego kościoła byli Skórzewscy, którzy też świątynię tę utrzymywali. Nabożeństwa odbywają się tu w co trzecią niedzielę. Zaprzysiężonymi kościelnymi byli Marcin Lewandowski i Wojciech Zarembski, k. $408 \mathrm{v}$.

Wykaz inwentarza kościelnego, a więc naczyń liturgicznych i pozostałych paramentów liturgicznych, k. 408v-409.

Wykaz stanu okręgu ,parafialnego” tego kościoła. Stare Polaszki, gdzie katolików było 162, zaś innowierców „Lutrów” 55; Nowe Polaszki liczyły 70 katolików i tam znajdował się zbór protestancki, Wilczebłoto miało 10 katolików i akatolików 2, zaś na folwarku Sztacha też było 4 akatolików, k. 409-409v. 
Opis stanu uposażenia dla parafii Polaszki, które miały cztery łany ziemi, o co upominał się aktualny proboszcz (z Kiszewa), ziemie tę na drodze sądowej odzyskał i aktualnie wydzierżawił. Wykaz oddawanej należności z wsi „parafialnych”. Znajdowały się tu też niewielkie zabudowania, k. 409v.

Protokół ten podpisany przez wizytatora w Kiszewie dnia 19 IX 1780 r. przez wizytatora Łukasza Jana Krzykowskiego, k, 409v-411.

Dekret reformacyjny dla parafii Kiszewa i kościoła filialnego w Polaszkach wystawiony dnia 19 IX 1780 r., podpisany przez wizytatora Łukasza Jana Krzykowskiego, k. 410.

Odpowiedzi na pytania postawione podczas wizytacji kościoła parafialnego w Kiszewie sporządzony i podpisany przez Andrzeja Schulza, proboszcza w Kiszewie, k. 413-421.

Odpowiedzi na pytania dotyczące kościoła filialnego w Polaszkach. Proboszcz z Kiszewa, Andrzej Schulz, dał tu bardzo dokładny opis świątyni oraz przytoczył odpisy dokumentów w związku ze staraniem się o odzyskanie (skuteczne) ziemi parafialnej. Odpowiedzi te zaaprobowane przez wizytatora Łukasza Jana Krzykowskiego dnia 19 IX 1780 r., k. 422-428v.

[Wizytacja dekanatu starogardzkiego]

Wykaz tabelaryczny parafii dekanatu starogardzkiego ${ }^{64}$. Wszystkie parafie położone były w powiecie starogardzkim. Parafia Starogard, proboszcz Jan Bastkowski i wikariusz Michał Potyłowski; parafia Kokoszkowy, proboszcz Kazimierz Sciankowski z zakonu dominikanów z Tczewa; parafia Klonówko, proboszcz Maciej Pruczkowski, parafia Bobowo, proboszcz Stefan Reznnerowski; parafia Zblewo, proboszcz Tomasz łyszkowski i wikariusz Jan Bąkowski; parafia Czersk, proboszcza nie było, a zarządzał ksiądz Józef Dolentowski; Kiszewa, proboszcz Andrzej Schulz, wikariusza tymczasowo nie było; parafia Pogutki, proboszcz Anzelm Powalski z zakonu cysterskiego z Pelplina; parafia Pinczyn, proboszcz Józef Tendycki, k. 421ª.

P o g u t k o w y. Wizytacja generalna kościoła parafialnego w Pogutkowach, odbyta w 1780 r., k. $428^{\mathrm{a}}$.

Wykaz tabelaryczny miejscowości parafialnych w parafii Kogutki. Na terenie tej parafii nie było Żydów. Pogutkowy liczyły 124 katolików, z czego spowiadało się 85 osób, zaś akatolików mieszkało 20; Jaroszewy 96, 72, 25; Kosmin, 84, 60, akatolików nie było; Kleszczewo 64, 46, 30; Kobyle, 66, 50, 20; Czernikowy 35, 22, 18; Więckowy 120, 80, 10; Jądrowy 39, 20, 15; Głodowo 84, 65, akatolików nie było; Malkowy 27, 18, 22; Malary 23, 16, 10; Deka 16, 10, 8; Tomaszewko 9, 6, 10; Ryle 18, 8, 20; Jezierze jedynie 40 akatolików; Zawada 2, 2, 17; Lisewko 1, 1, 10; Wałdowko 5, 3, 15; Lipiagóra 1, 1, 30; Bukowiec jedynie 8 akatolików;

${ }^{64}$ Wykaz ten powinien znajdować się tam, gdzie rozpoczęto wizytacje dekanatu starogardzkiego i podano jego charakterystykę. Przez pomyłkę wklejono tę tabelę w tym miejscu. 
Bara 12, 8, akatolików nie było; Brzęczek 5, 3, 4; Milonki 5, 4, 6; Szczepanowo 6, 4, akatolików nie było. Ogółem zatem na terenie parafii było 834 katolików i 336 akatolików, k. 429.

Kościół w Pogódkach, murowany, był pod wezwaniem św. Piotra i Pawła. Prawo patronatu zakonnego opata i opactwa w Pelplinie. Obecna świątynia zbudowana przez opata pelplińskiego, biskupa tytularnego Diana, Tomasza Czapskiego, w 1715 r., konsekrowany w 1764 r. przez biskupa sufragana chełmińskiego Fabiana Pląskowskiego. Stan świątyni dobry. Wyposażenie w paramenty liturgiczne znajdujące się w zakrystii wystarczające. Kościół miał sześć ołtarzy. Były relikwie z dokumentami autentyczności oraz przywileje odpustowe. Nie było prebend i osobnych beneficjów. Bractwo Aniołów Stróżów, zaprowadzone w 1637 r. Jego kapelanem był proboszcz miejscowy. Nie było żadnych kaplic, także prywatnych. Szkoła w Więckowach utrzymywana przez rząd, gdzie uczył Teofil Gotwalt. Obok świątyni znajdował się domek, zwany przytułkiem, ale nie było ani uposażenia, ani podopiecznych, k. 430-431v.

Sposób sprawowania sakramentów, k. 431.

Proboszcz Anzelm Piotr de Lewald Powalski, zakonnik z opactwa pelplińskiego, którego $\mathrm{w}$ razie potrzeby wspomaga inny kapłan $\mathrm{z}$ tego klasztoru. Innych osób duchownych w parafii nie było. Parafianie nie sprawiali większych kłopotów, k. 431-431v.

Opis uposażenie beneficjum. Były dwa łany ziemi z przeznaczeniem na remonty świątyni oraz osiem łanów dla duszpasterza, co było zazwyczaj wydzierżawiane. Ponadto niektóre wioski, tu wyliczone, więc Więckowy, Jaroszewy, Kleszczewo, Kosmin, Głodowo, Jakrowy i Malary oddawały meszne. Proboszcz stwierdził, że dochody nie wystarczały dla duszpasterza i utrzymania przytułku, $\mathrm{k}$. 432.

Dokładny opis świątyni murowanej i jej wyposażenia. Zakrystia murowana, a przy niej kaplica bractwa z ołtarzem Anioła Stróża. Po drugiej stronie kaplica Matki Boskiej oraz kaplica z ołtarzem św. Jerzego. Spis argentariów i innych naczyń liturgicznych i sprzętów. Opis plebanii drewnianej, pod dachówką i innych zabudowań gospodarczych. Inwentarza żadnego nie było, k. 432-434.

Protokół podpisany przez wizytatora Łukasza Jana Krzykowskiego i sekretarza Macieja Formela, k. 434.

Dekret reformacyjny dla parafii w Pogótkowach z dnia 23 IX 1780 r., wystawiony i podpisany przez wizytatora Łukasza Jana Krzykowskiego, k. $433^{65}$.

Odpowiedzi na pytania postawione $\mathrm{z}$ racji wizytacji generalnej parafii Pogutkowy, przeprowadzonej w 1780 r. Sporządzone w formie odpowiedzi na 328 pytań. Sporządził je proboszcz Anzelm Powalski i przyjął je 23 IX 1780 r. wizytator Łukasz Jan Krzykowski, k. 435-439.

P i n c z y n. Wizytacja kościoła parafialnego w Pinczynie, odbyta w 1780 r., k. 440.

${ }^{65}$ Karta z dekretem wklejona później, dlatego zakończenie samego protokołu wizytacyjnego jest jeszcze na karcie 434 . 
Świątynia pod wezwaniem św. Elżbiety, prawa patronatu świeckiego. Opis położenia względem najważniejszych miejsc w diecezji. Kościół aktualnie stojący został wzniesiony w 1742 r. staraniem Stanisława i Katarzyny Skórzewskich, starostwa kiszewskich oraz innych dobroczyńców i praca parafian. Konsekracji dokonał w 1759 r. biskup Fabian Pląskowski sufragan i oficjał generalny chełmiński. Prawo kolatorskie aktualnie należało do Anny Święcickiej, dziedziczki wsi Pinczyn. Stan kościoła dobry i nie wymagał naprawy. Krótki jej opis i wyposażenia zakrystii. Opis sześciu ołtarzy i obrazów, ale obrazu łaskami słynącego nie było. Nie było też kaplic, prebend, ani osobnych beneficjów. Bractwo św. Józefa aprobowane przez Stolicę Apostolska, utrzymywane z ofiar. Posiadało nieco swoich paramentów liturgicznych. Nie było kaplic prywatnych, a nawet innowiercy nie posiadali swojego zboru. Żydów nie było. Ponieważ nie istniała tu także szkoła, dlatego organista uczył podstaw pisania i czytania. Brak przytułku, a ubodzy żyli z jałmużny, k. 441-443.

Wykaz tabelaryczny wsi parafialnych. Pinczyn liczył 142 katolików, spośród których spowiadało się na Wielkanoc 98 osób, zaś akatolików na terenie tej wsi było 8; Pinczynem 5, 3, 4; Przemyśle nie miało katolików, a jedynie 5 akatolików, Samlin 51, 32, 32; Sadlinek miał jedynie 10 akatolików; Góra 75, 57, 20; Nowydworzec miał tylko 36 akatolików; Borowa Karczma 1, 1, 6; Pisienica 95, 73, 46; Bukowiec 5, 4, 5; Sukimin 69, 41, 41; Sukuminek jedynie 8 akatolików; Pałubinek jedynie 6 akatolików. Ogółem parafia liczyła 443 parafian, a na jej terenie mieszkało 227 akatolików, k. 442.

Sposób sprawowania sakramentów, k. 443443v.

Proboszcz Jan Tendycki, osobiście sprawujący duszpasterstwo. Organista i zakrystianem był Wojciech Piotrkowski. Zakonników na terenie parafii nie było. Parafianie nie sprawiali większych kłopotów, k. 443v-444v.

Uposażenie parafii. Witrykusi Łukasz Baszkowski i Jakub Bajar trzymali ofiary na naprawę świątyni i inne wydatki. Opis uposażenia proboszcza. Pobierał także meszne z wsi parafialnych, tu wyliczonych. Wykaz wydatków. Opis zabudowań plebańskich i inwentarza gospodarskiego, tak żywego, jak i martwego, k. 444v-445 .

Dokładny opis świątyni drewnianej, pod dachówką, jej wnętrza i otoczenie. Kościół miał sześć ołtarzy. Podano jakie znajdowały się tu obrazy. Zakrystia z drewna. Spis argentariów i pozostałych paramentów liturgicznych i innego sprzętu, k. 445-447.

Protokół ten podpisany przez wizytatora Łukasza Jana Krzykowskiego w Pinczynie, dnia 17 X 1780 r., k. 447.

Dekret reformacyjny dla parafii Pinczyn, wystawiony i podpisany przez wizytatora Łukasza Jana Krzykowskiego w dniu 17 X 1780 r., k. 446.

Odpowiedzi na pytania postawione podczas wizytacji generalnej parafii Pinczyn, ujęte w wyjaśnienia do każdego z 328 pytań. Na koniec podano szczegółowy wykaz inwentarza gospodarskiego, opis stanu świątyni i wykaz argentariów, pozostałych paramentów liturgicznych i innego sprzętu. Osobno jeszcze opisano ołtarze oraz obrazy i figury znajdujące się w świątyni. Odpowiedzi twe sporzą- 
dzone zostały przez proboszcza Tendyckiego i zaaprobowane przez wizytatora Łukasza Jana Krzykowskiego, k. 449-456.

Alfabetyczny indeks wizy towanych parafii, z podaniem kart, sporządzony w języku niemieckim, k. 456.

\section{G71}

[1. Sygn. akt.] G71.

\section{A. OPIS KSIĘGI}

[2. Tytuł oryg.] Visitatio Generalis Ecclesiae Parochialium Decanatuum Neoburgensis ac Maevensis ex mandato Illustrissimi ac Reverendissimi Domini Dimini Josephi Rybinski, episcopi Vladislaviensis et Pomeraniae, per Perillustrem Admodum Reverendum Andream Schultz, Canonicum Crusviciensem, Decanum Foraneum Dirschaviensem, Parochum Kiszeviensem et Polaszkoviensem, Visitarorem Generalem Deputatum in Anno 1780 et 1781-mo expedita.

[3. Daty krańc.] 1780-1781.

[4. Opis zewn.] Łac.-pol. $(26,0 \times 22,0)$ Kart paginowanych z numerami pisanymi ołówkiem 351. Zastapiono dawną numerację pisaną piórem. Stan zachowania księgi dosyć dobry. Oprawa stara w półskórek w stanie dobrym. Na odwrociu okładki napis: Rybiński per Schultz 1780-1781. Karta niefoliowana na początku księgi z pieczęcią Archiwum Diecezjalnego w Pelplinie.

Karty puste: $1 \mathrm{v} ; 2 \mathrm{v}-3 \mathrm{v} ; 5 \mathrm{v}, 19 \mathrm{v} ; 22 \mathrm{v} ; 26 \mathrm{v} ; 28 \mathrm{v} ; 45 \mathrm{v} ; 46 \mathrm{v} ; 48 \mathrm{v} ; 61 \mathrm{v} ; 72 \mathrm{v} ; 123 \mathrm{v}$; $136 \mathrm{v} ; 152 \mathrm{v} ; 154 \mathrm{v} ; 158 \mathrm{v} ; 165 \mathrm{v} ; 187 \mathrm{v} ; 197 \mathrm{v} ; 209 \mathrm{v} ; 225 \mathrm{v} ; 231 \mathrm{v} ; 243 \mathrm{v}, 312 \mathrm{v}, 319 \mathrm{v}$, $320,321 \mathrm{v}, 337 \mathrm{v}, 352 \mathrm{v}, 360 \mathrm{v}-361 \mathrm{v}$.

Niektóre karty puste, nie objęte foliacją, mają obcięte narożniki. Pismo kilku rąk. $5 \mathrm{v}$;

[5. Uwagi]. Pismo w zasadzie bardzo staranne i czytelne, ale nie wszystkie protokoły. Nieraz poprzestano na opisie danym przez samego proboszcza. Te opisy nieraz bardzo dokładne, nieraz bardziej powierzchowne. Nie zawsze można się dowiedzieć, kiedy dokładnie była przeprowadzana wizytacja i spisywany protokół.

Papier w księdze pochodzący z różnych papierni.

Protokóły nie są ułożone chronologicznie, widać, że księga skompletowana później.

Ponieważ są niejednokrotnie dwa opisy parafii, w tym jeden sporządzony przez proboszcza i z jego osobistym podpisem. Zdaje się, że to proboszczowie przygotowywali opisy, z których prawie dosłownie korzystał wizytator. Przy sporządzaniu repertorium zbędnym okazało się powtarzanie tych samych wiadomości. Ale wydaje się, że niezbędnym było podawanie nagłówków tych podwójnych opisów.

Przy oprawie księgi poczyniono pomyłki w składaniu, stąd niektóre, zwłaszcza tabele, oddzielone są od właściwego opisu parafii.

Przy miejscowościach podawano zazwyczaj, kto był właścicielem, ale tego w niniejszym repertorium nie notowano. 
Przy opisie stanu moralnego parafian zwracano uwage, czy nie było publicznych grzeszników, łamiących dekalog, czy nie porzucano żon oraz czy nie oddawano się złym zwyczajom miejscowym.

Opis stanu materialnego zawsze uwzględniał grunta, łąki, lasy, ale w repertorium, ponieważ przy poprzednich wizytacjach nieraz podawano to szczegółowo, tym razem to pomijano.

\section{B. ZAWARTOŚĆ KSIĘGI}

Indeks parafii opisanych $\mathrm{w}$ księdze, sporządzony w języku niemieckim z podaniem stron, z uwzględnieniem także dawnej numeracji, k. 2.

Strona tytułowa (druga) z napisem: Visitatio G[enera]lis Decanatus Neoburgensis et Maevensis Dioecesis Pomeraniae per Perill[ust]rem Andream Schultz visitatorem G[enera]lem deputatum, peracta in $\mathrm{A}[\mathrm{nn}] \mathrm{o}$ 178- ad 1781, k. 4.

Zestawienie tabelaryczne dekanatu nowomiejskiego z podaniem parafii dekanalnych i kościołów filialnych. Były to parafie: Skórcz, Nowe, Komórsk, Lubień, Płochocin, Jania (Kościelna Jania), Barłożno, Lalkowy, Pieniążkowo. Podano imiona proboszczów oraz krótką charakterystykę duchowieństwa, k 4v-5.

P i e n i ą ż k o w o. Opis świątyni we wsi Pieniążkowo, pod wezwaniem św. Jana Chrzciciela, w archidiakonacie, oficjałacie i województwie pomorskim. Świątynia murowana, wzniesiona w 1592 r. przez kasztelana chełmińskiego Jana Oleskiego, jak to wynikało z tablicy marmurowej znajdującej się przy wejściu. Konsekrowana 29 IX 1593 r. przez biskupa Hieronima Rozdrażewskiego. Dawniej prawo patronatu należało do ordynariusza miejscowego, a aktualnie do dziedzica dóbr Ostrowite, kasztelana brzesko-kujawskiego, Pawła Dąbskiego. Miejscowości parafialne, Pieniążkowo, Półwsie, Dabrówka, Ostrowite, Czerwińsk, Luchowo, Smarzewo, Kolmaga, Wiosło, Murowany Młyn, Stary Młyn i Mały Młyn będą omówione w wykazie tabelarycznym, k. 6.

Opis świątyni (w języku polskim) znajdującej się w dobrym stanie. Grobowiec murowany fundatorów Jana Oleskiego i Zuzanny, kasztelaniców chełmińskich. Opis otoczenia kościoła, z dzwonnicą murowaną z dzwonami, kostnicą i ogrodzeniem. Wyposażenie w paramenty liturgiczne znajdujące się w zakrystii. Opis trzech ołtarzy oraz obrazów. Relikwii nie było. Przywileje odpustowe. Bractwo Aniołów Stróżów zaprowadzone w 1642 r. Promotorem był sam proboszcz. Była księga przywilejów i obowiązków członków bractwa oraz ich spis. Kaplic ani osobnych prebend nie było. Byli w granicach parafii wierni wyznawcy protestantyzmu, niemający swojej kaplicy a jedynie miejsce w narożniku cmentarza, gdzie chowają swoich zmarłych. Pustelników, ani Żydów nie było w parafii. Szkoły nie było, ale organista uczył dzieci podstaw wiary i nauki. W Pieniążkowie istniał przytułek, bez własnego uposażenia, a było w nim czterech ubogich, mężczyzna i trzy niewiasty, żyjący z Jałmużny, k. 6v-7v.

Sposób sprawowania sakramentów, k. $7 \mathrm{v}-8$. 
Proboszcz Paweł Omieński, lat 49, święcony w 1755 r. Rezyduje przy parafii. Nabożeństwa sprawuje należycie. Księgi parafialne prowadzi. Nie ma zastrzeżeń, co do postawy moralnej. Wikariusz Józef Świdziński, lat 33, święcony w 1770. Organistą od 1776 r. był Stanisław Toskowski. Zakonników nie było. Parafianie zasłużyli na dobrą ocenę moralną, k. 8-8v.

Opis stanu ekonomicznego parafii. Odpis przywileju dla probostwa w Pieniążkowie, wystawiony 20 V 1763 r. przez kasztelana z Lubrańca Dąbskiego. Inne uposażenie, to ziemia oraz dziesięcina oddawana przez poszczególne wsie. Prowizorami byli Jan Frankiewicz i Maciej Marchlewski. Opis innego uposażenia, k. $8 \mathrm{v}-9 \mathrm{v}$.

Spis dokładny inwentarza kościelnego, a także gospodarczego, z opisem zabudowań plebańskich, opisu domu dla organisty i przytułku, k. 10-12.

Protokół ten podpisany i pieczęcią (w opłatku) uwierzytelniony przez Andrzeja Szhultza i Jan Klińskiego, który był notariuszem, k. 12.

Dekret reformacyjny wystawiony w Pieniążkowie 27 V 1781 r., k. 12v.

Opis parafii, właściwie nie różniący się od powyższego, sporządzony (zapewne pod jego dyktando) przez proboszcza Pawła Osieńskiego i własnoręcznie przez niego podpisany, k. 13-19.

Wykaz tabelaryczny parafii Pieniążkowo. Pieniążkowo, gdzie katolików było 102, z czego komunikujących 75, zaś akatolików 11; Półwsie 94, 68, zaś akatolików nie było; Dąbrówka 70, 52, 6; Ostrowite 99, 87, 39; Czerwińsk 82, 58, akatolików brak; Luchowo 58, 35, 10; Smarzewo 49, 34, 3; Kolmaga 29, 25, 9; Wiosło 44, 34, 31; Murowany Młyn 10, 9, 7; Stary Młyn 2, 2, 5; Mały Młyn jedynie 4 akatolików. Ogółem 639 katolików, z czego spowiadających się 482 oraz 125 akatolików, k. $20^{66}$.

Wykaz tabelaryczny dekanatu gniewskiego.

Należały doń parafie z proboszczami: Nowa cerkiew, inkorporowana do opactwa w Pelplinie - Fabian Ustarbowski i wikariusz Izydor Lossau, zakonnicy cystersi; Gniew - Michał Dąbrowski, kanonik poznański i wikariusz Deodatus Arent; Pączewo - Antoni Lewiński i wikariusz Paweł Latosiewicz; Lignowy (pisano Libnowy), filia parafii Szprudowo - proboszcza nie było, wikariusz Wawrzyniec Michnowski, Walichnowy - Kajetan Rembieliński i wikariusz Walerian Pelnerowski, Grabowo (?) - Józef Żurkatowski; Rajkowy - Michał Łabuszewski, Pelplin (cysterski) - Gwillelm Kostrzewski, Dzierżązno - proboszcza nie było, wikariusz Daniel Postel. Razem było w dekanacie 10 parafii, 8 proboszczów, 7 wikariuszy i 34 zakonników w opactwie cysterskim w Pelplinie, k. 21.

Wizytacja dekanatu gniewskiego w diecezji pomorskiej 1780, k. 22.

Opis dekanatu gniewskiego z podaniem parafii i ich odległości od siedziby dziekana. Podano nazwiska duchowieństwa. Wizytację poprzedziły dwie kongregacje dekanalne, gdzie podano przez dziekana zarządzenia pastoralne. Dziekanem

${ }^{66}$ Przy sporządzaniu opisu tych tabel, w dalszej części wymieniano wszystkich parafian katolików, potem liczbę spowiadających się, a potem podawano liczbę akatolików, oraz Żydów. Gdy tych ostatnich nie było, stawiano znak: ,-,,, 
był Fabian Ustarbowski, doktor teologii, cysters, proboszcz w Nowem i dziekan gniewski, który opis ten podpisał., k. 23-26.

Nowa Cerkiew, dekanat gniewski, k. 27.

Wykaz tabelaryczny parafii Nowa Cerkiew. Należały do niej wsie: Nowa Cerkiew,. Licząca akatolików 270, z czego spowiadało się 283 i było 7 katolików; Morzeszczyn 116, 103, 10; . Genomie 95, 78, 3; Kulice 109, 69, 7; Rozental 154, 124, akatolików brak; Krółówlas 151, 120, akatolików brak; Molendinum Krolówlasense 8, 7, akatolików brak; Rzezęcin 171, 142, 3; Borkowo 134, 103, 30; Olszowka 26, 23, akatolików brak; Olsze 22, 19, 10; Smolążek 12, 12,alatolików brak; Brzyzno 5, 4, 5; Rombarg 77, 65, 7; Ropuchy 35, 26, 5; Bielawki 111, 84, 4. Ogółem katolików było 1499, w tym po spowiedzi wielkanocnej 1168, akatolików natomiast 91, k. 27.

K o ś c i e 1 n a J a n i a. Kościół we wsi Kościelna Jania, pod wezwaniem Świętej Trójcy, prawa patronatu świeckiego. Opis jego położenia. Prawo patronatu należało do Stanisława z Małachowic Małachowskiego, starosty sądeckiego i Urszuli Czapskiej, córki Tomasza i Marianny z Czapskich. Do parafii należały wsie: Kościelna Jania, Stara Jania, folwark Kownatka, folwark Bobrowiec, Pastwisko, czyli Wołownik, Wielkie Komorze, Małe Komorze, Długoleszcz, Grabowiec, Nicponi, Nowe Kolonie czyli Pustkowia, Leśna Jania, Naszczerz, Młyn Słuchacz, Skarpiec, Nowe Kolonie czyli Pustkowia Królewskie Borysz. katolików ogółem było 620, komunikujących na Wielkanoc 234, akatolików 59, Żydów nie było. Relikwii nie było. Przywileje odpustowe z racji bractwa Świętej Trójcy. Prebend i osobnych beneficjów nie było. Bractwo Świętej Trójcy założone w 1748 r za zezwoleniem Stolicy Apostolskiej i wiedzą Konsystorza Pomorskiego, Bractwo to posiadało swoje księgi, obrazy. Kaplicy żadnej nie było. Szkoły nie było, ale uczył organista Mateusz Dubielski. Przytułek, gdzie było sześć kobiet, pod opieką proboszcza. Był na to skromny zapis lokowany w Nowem, k. 29-30,

Sposób sprawowania sakramentów, k. 30-31,

Proboszcz Józef Halba, lat 47, święcony w 1763 r. Wykładał teologię moralną w szkole w Szotlandzie. Obowiązki proboszcza spełnia gorliwie. Księgi metryk prowadził. Nie było spisanego inwentarza. Spis książek. Zakonników żadnych nie było. Opinia o parafianach, k. 31-32.

Stan ekonomiczny beneficjum z wykazem mesznego, dochodów i rozchodów, zabudowania plebańskie $\mathrm{w}$ stanie średnim. Opis stanu świątyni murowanej, z dwiema kaplicami i ze sklepieniem. Posadzka z cegły. Grobowiec murowany. Opis otoczenia świątyni, k. 32-33.

Spis paramentów liturgicznych i szat, choragwi, k. 33-34v

Opis trzech ołtarzy, k. 34v.

Spis inwentarza gospodarczego. Ten opis świątyni i parafii sporządził zapewne, bo go podpisał, Jan Halb, proboszcz parafii Jania, k. 28.

B a rło ż n o, dekanat nowomiejski, k. 36. Wykaz tabelaryczny parafii Barłożno. Należały do niej wsie: Barłożno liczące 336 katolików, z czego na Wielkanoc 
spowiadało się 259 osób, zaś akatolików była 1 osoba; Mirotki 200, 147, 22; Lipiagóra 163, 113, 19; Gąsiorki 118, 91, 5; Kierwałd 57, 49, akatolików 2; Piła Molendinum 26, 18, akatolików brak; Olszowiec 19, 12, akatolików brak, Markocin 14, 13, akatolików brak. Ogółem więc na teranie parafii było 933 katolików, z czego spowiadających się na Wielkanoc 702 oraz 49 akatolików, k. 36.

Wizytacja kościoła parafialnego we wsi Barłożno. Świątynia pod wezwaniem św. Marcina, patronatu monarszego, pochodząca z czasów krzyżackich. Opis położenia parafii. Wsie należące to Barłożno, Mirotki, Lipia Góra, Gąsiorki, Kierwałd, Piła, Olszowiec, Markocim. Opis świątyni murowanej, w stanie dobrym, zmałą kaplicą pod wezwaniem Pana Jezusa Ukrzyżowanego, od którą znajdował się mały grobowiec. Zakrystia wyposażona wystarczająco w najważniejsze paramenty. Opis trzech ołtarzy i obrazów, Relikwii nie było. Przywileje odpustowe z racji bractwa św. Izydora, a także na inne święta. Bractwo zaprowadzone w $1648 \mathrm{r}$. Nie posiadało specjalnego uposażenia, ale miało swoje księgi statutów, księgi członków bractwa oraz swoje paramenty liturgiczne przy ołtarzu św. Izydora. Kaplicy żadnej nie było. W całej parafii było 49 członków religii protestanckiej, ale nie mieli oni swojej kaplicy, jedynie plac na cmentarzu, gdzie się chowali. W Barłożnie jest nauczyciel na pensji rządowej, który uczył w jednym z pomieszczeń w przytułku. Przytułek zbudowany kosztem parafian, a w nim kilku starców, k. 38-39v.

Sposób sprawowania sakramentów, k. 40.

Proboszcz Andrzej Dobrowolski, kanonik krakowski, lat 53, święcony w 1752 r., pochodzący z Mazowsza, stale rezydujący w parafii. Wikariusza aktualnie nie posiadał. Organista, kościelnym i dzwonnikiem w jednej osobie był Antoni Chmielecki. Witrykusi Maciej Klejna i Józef Wałkowski. Zakonników żadnych nie było. Obyczaje parafian nie nastręczały wątpliwości, k. 40-40v.

Stan ekonomiczny beneficjum. Wykaz oddawanych dziesięcin oraz wykaz dochodów i wydatków, k. 40v-41v.

Inwentarz dokładny paramentów liturgicznych, innych sprzętów kościelnych i ksiag. Spis inwentarza gospodarczego żywego i martwego, k. 42-43.

Opis zabudowań plebańskich, a także budynków organisty i dokładny opis jego dochodów. Sam organista, jak to zapisano w protokole, łożył na remonty organistówki z własnej kieszeni i własną praca, k. 43-44.

Opis szpitala wystawionego nakładem parafian, gdzie mieszkało troje ubogich. Inspektor królewski uczył tam dzieci. Szpital nie miał żadnych funduszy, a ubodzy żyli z jałmużny, k. 44.

Protokół powizytacyjny spisany w Barłożnie dnia 16 II 1781 r., podpisany przez wizytatora Józefa Schulza i notariusza Jana Klińskiego, k. 44.

Zestawienie tabelaryczne parafii, identyczne z poprzednim, jaki na karcie 36 był sporządzony, k. 45 .

Dekret reformacyjny, wystawiony w Barłożnie 16 II 1781 r., k. 46.

L a 1 k o w y, dekanat nowomiejski, k. 47. Wykaz tabelaryczny parafii Lalkowy. Parafia obejmowała wsie: lalkowy, gdzie było 150 katolików, z czego po spowiedzi wielkanocnej 105 oraz 5 innowierców; Włosiennica 54, 34, innowierców brak; Smętowo 78, 59, 5; Jeżewnica 8, 4, 20; Jasieniec 8, 6. innowierców brak; 
Rynkówka 237, 159, 11; Cysowy 25, 15, 15; Bukowiny 35, 26, akatolików brak; Frąca 181, 96, 8; Udzież 38, 28, akatolików brak; Kopytkowo 193, 137, 23; Smętówko 56, 37, 11. Ogółem więc było 1963 katolików, z czego po spowiedzi wielkanocnej było 709, zaś akatolików naliczono 98. k. 47v-48.

Wizytacja kościoła parafialnego w Lalkowych. Kościół we wsi Lalkowy pod wezwaniem św. Barbary, murowany, z czasów krzyżackich, konsekrowany w 1409 roku, prawa patronatu monarszego. Opis położenia parafii. Wsie parafialne - tak jak w tabeli. Opis dokładny świątyni znajdującej się w dobrym stanie, ale dach wymaga pewnej naprawy. Wewnątrz, pod prezbiterium, znajdowały się trzy grobowce (sklepy). Epitafium biskupa włocławskiego Walentego Czapskiego, gdzie też złożono jego serce. Opis otoczenia świątyni. Zakrystia wyposażona w potrzebne paramenta, szaty i inne utensylia kościelne. Opis pięciu ołtarzy i obrazów. Znajdowały się tu relikwie z dokumentami autentyczności. Wykaz przywilejów odpustowych. Bractwo św. Barbary zaprowadzone za zgoda Stolicy Apostolskiej, ale nie posiadało własnego uposażenia i utrzymywało się z jałmużny. Kaplicy publicznej nie była. Kaplica prywatna we dworze Czapskich w Rynkówce, za zgodą władzy kościelnej, ale zdarza się, że gdy jest tu sprawowana msza przez jakiegoś zakonnika, wierni tu uczestniczą we mszy w niedziele i święta. Protestanci nie mieli swojej kaplicy. Szkoły nie było, ale organista uczył podstaw wiary i „literatury”. Przytułek za kościołem, bez własnej kaplicy i uposażenie, a w nim trzech ubogich żyjących z samej jałmużny, k. 49-50v.

Sposób sprawowania sakramentów, k. 50v.

Proboszcz Samuel Rutkowski, lat 48, kanonik chełmiński. Duszpasterstwo sprawuje osobiście i przy pomocy wikariusza Piotra Dygowskiego. Organista Jakub Raykowski, zakonników nie było. Poziom moralny parafian różny, k. 51.

Stan ekonomiczny parafii. Wykaz pobieranych dziesięcin oraz dochodów i rozchodów, k. 51v-52,

Inwentarz dokładny paramentów kościelnych oraz książek, k. 52-53.

Inwentarz gospodarczy inwentarza żywego i martwego. Opis stanu zabudowań plebańskich. Stan organistówki i opis uposażenia organisty, k. 53-53v

Opis szpitala. Zapisano, że są trzy akuszerki pouczone o sposobie udzielania chrztu in „,casu necessitatis”, k. 53v-54.

Protokół wizytacyjny podpisał Andrzej Józef Schulz, wizytator i Jan Kliński jako notariusz, dnia 30 I 1781 r., k. 54.

Dekret reformacyjny wystawiony w Lalkowych dnia 30 I 1781 r., zapewne przez wizytatora, k. $54-54 \mathrm{v}$.

Opis kościoła i parafii, zgadzający się treścią z poprzednim protokołem, a nawet identyczna tabela, sporządzone i podpisane przez proboszcza Samuela Rutkowskiego, k. 55-61.

P i e n i ąż k o w o, dekanat nowomiejski. Wykaz tabelaryczny parafii Pieniążkowo. Zgadza się on dosłownie z tabelą podaną na karcie 20 wyżej. 
Wizytacja kościoła parafialnego w Nowej Cerkwi i ${ }^{67}$. Kościół pod wezwaniem Wniebowzięcia Najświętszej Marii Panny, świętych Piotra i Pawła oraz św. Mateusza. Prawo patronatu należało do opata z Pelplina. Opis położenia parafii. Obecny kościół fundowany w 1764 r. przez opata Izydora Tokarzewskiego. Świątynia murowana, kryta dachówką. Dokładny jej opis oraz stan otoczenia. Zakrystia wyposażona w potrzebne utensylia. Opis krótki siedmiu ołtarzy oraz obrazów. Relikwie Świętego Krzyża i inne. Przywileje odpustowe. Nie było osobnych kaplic ani prebend. Bractwo Różańcowe zaprowadzone w 1632 r., prowadzące księgę przyjmowanych członków bractwa. Nie miało specjalnego uposażenia, ale zdaje się, że miało włókę ziemi we wsi Nowa Cerkiew, nadaną przez opata Leonarda Rembowskiego. We wsi Borkowo znajdowała się kaplica zbudowana w pruski mur, pod wezwaniem św. Jakuba Apostoła, z fundacji opata pelplińskiego, gdzie odprawiał jeden z zakonników, zanim Borkowo nie zostało zabrane przez rząd pruski. Zakonnicy zabrali wyposażenie kaplicy, klucze aktualnie ma Proboszcz parafii Nowa Cerkiew i odprawia jedynie w święto patrona. Innych oratoriów nie było. Akatolicy nie mieli swojego zboru. Żydzi byli we wsi Ropuchy, ale też nie mieli własnej synagogi. We wsi parafialnej był nauczyciel Jan Hoeger, katolik uczący około dziesięcioro dzieci. Przytułek przy kościele, gdzie mieszkały trzy wdowy, żyjące z jałmużny, k. 64-65.

Sposób sprawowania sakramentów, k. 65-65v.

Proboszcz Fabian Michał Ustarbowski, doktor teologii, dziekan gniewski, zakonnik cysterski. Wikariusz Izydor Lossau, zakonnik cysterski. Innych zakonników nie było. Stan moralny parafian nie budził większych zastrzeżeń, k. 65v-66.

Stan ekonomiczny parafii z wykazem pobieranej dziesięciny, dochodów i rozchodów, k. 66-67.

Inwentarz paramentów liturgicznych, szat liturgicznych, bielizny oraz ksiag kościelnych, k. 67-68v.

Inwentarz rzeczy posiadanych przez bractwo, k. $68 \mathrm{v}$.

Inwentarz gospodarczy zwierząt i sprzętów oraz opis zabudowań plebańskich i mieszkania organisty, k. 69,

Wizytacja kościoła filialnego we wsi K r ó łó w la s, inkorporowanego do parafii Nowa Cerkiew. Świątynia w tej wsi, pod wezwaniem św. Mikołaja, fundowana przez konwent cysterski w Pelplinie. Do tego kościoła należała sama wieś Królówlas i osada młyńska, katolików ogółem było 151, z czego do sakramentów zobowiązanych było 110. Akatolików i Żydów nie było. Kościół wystawiony w pruski mur, wymagał znacznej naprawy. Dach zaciekał. Cmentarz nie był ogrodzony z niedbalstwa. Opis otoczenia kościoła, k. 70.

Spis wyposażenia w paramenty liturgiczne. W świątyni trzy ołtarze oraz kilka obrazów. Relikwii nie było. Przywilej odpustowy na niedzielę przed świętem św. Rocha. Na uposażenie były trzy łany, dane niegdyś przez opactwo. Jeden łan na potrzeby kościoła, a dwa dla proboszcza w Nowej Cerkwi, k. 70-71v.

\footnotetext{
${ }^{67}$ Wykaz tabelaryczny tej parafii umieszczono niżej na karcie $27 \mathrm{v}-28$.
} 
Protokół podpisany we wsi Nowa Cerkiew, dnia 10 X 1780 r. przez wizytatora Andrzeja Józefa Schulza i notariusza Jana Klińskiego, k, 71v,

Dekret reformacyjny wystawiony w Nowej Cerkwi 19 X 1780 r.

Wykaz tabelaryczny parafii Nowa Cerkiew, identyczny z wykazem na karcie 27-28.

Wizytacja kościoła parafialnego w Nowej Cerkwi ${ }^{68}$, k. 73-87.

Wizytacja generalna kościoła filialnego Krółówlas ${ }^{69}$, k. 87-92v.

[G n i e w]. Wykaz tabelaryczny parafii Gniew. Do parafii należało miasto (civitas) Gniew, liczące 541 katolików, 441 spowiadających się na Wielkanoc, 449 akatolików i 50 Żydów; Ciepłe 176, 119, 68; Gronowo 206, 164, 167; Cierpice 20, 14, 4; Brody Niemieckie 120, 84, 16; Osada młyńska 21, 16, 12; Nicponia 53, 43, 46; Bursztach 66, 36, 93; Nowe Lichnowy 64, 44, 36; Jansdorf 94, 64, 200; Wielka Pastwa 76, 54, 166; Gniewskie Pole 21, 17, 330; Kacza Kępa 17, 10, 100; Foswynkiel 7, 4, 10; Kramrowskie 20, 19, 60; Gucz 29, 24, 122; Szalwinek 83, 63, 111; Szulwcza 16, 13, 14 oraz 52 menonitów; Małe Półko 45, 33, 78; Pazurowa Kępa 9, 6, 10; Strakweltowa Kępa 6, 6, akatolików brak; Tymawa 206, 168, 2; Rakowiec 134, 91, 4; Jazwiska 134, 101, 8. Ogółem parafia liczyła 2186 katolików, z czego na Wielkanoc spowiadało się 1634 osoby, akatolików było 1099, Żydów 50 i menonitów 52, k. 93.

Wizytacja Kościoła parafialnego w Gniewie. Kościół parafialny z tytułem archiprezbiteratu w wmieście (oppidum) Gniew, pod wezwaniem św. Mikołaja, prawa patronatu monarszego, dawniej króla polskiego, a teraz króla pruskiego. Opis położenia parafii. Do do parafii należał kościół filialny Tymawa. Wiernych w parafii całej 1689, przy kościele w Tymawie 480, akatolików 1099, Żydów 5070. Kościół w dobrym stanie, z kaplicą i zakrystią murowaną. Opis otoczenia świątyni. Zakrystia wyposażona w potrzebne paramenta liturgiczne. Ołtarzy w prezbiterium było trzy, w nawie sześć oraz w kaplicy św. Anny i św. Katarzyny. Opis obrazów. Opis relikwii i przywilejów odpustowych. Dwie kaplice, ale nie wiadomo przez kogo erygowane. Bractwo Różańcowe, zaprowadzone przez kanonika włocławskiego Zaporskiego ${ }^{71}$ i oficjała gdańskiego oraz bractwo św. Anny. Kaplica św. Jerzego za miastem oraz druga przy zamku Gniew. Żydzi posiadają swoja synagogę. Religia akatolicka ma swoje oratorium. Szkoły nie było, ale zakrystian uczył podstaw wiary i czytania. Przytułek dosyć dobry przy kościele, zbudowany z pruskiego muru, bez własnej świątyni, z funduszem dla ośmiu podopiecznych.

${ }^{68}$ Jest to dokładny opis parafii, zgadzający się z protokołem wizytacyjnym, sporządzony i podpisany przez Fabiana Ustarbowskiego, zakonnika cysterskiego, proboszcza z Nowej Cerkwi.

${ }^{69}$ Jest to dokładniejszy jeszcze, niż poprzednio, opis tego kościoła filialnego, sporządzony przez Fabiana Ustarbowskiego, zakonnika cysterskiego i proboszcza we wsi Królówlas.

${ }^{70}$ Te dane różnią się od tych, co zapisano w wykazie tabelarycznym.

${ }^{71}$ Biogram tego kanonika i oficjała zob. Chodyński, Katalog prałatów i kanoników włocławskich, rkps w Archiwum Diecezjalnym we Włocławku, k 1071-73; Czaplewski, Wykaz oficjałów gdańskich i pomorskich, s.65-66. 
To uposażenie zostało tu opisane. Mężczyźni mieszkają osobno od kobiet. Inni ubodzy mieszkają w domach parafian, k. 94-95v.

Opis sprawowania sakramentów, k. 95v-96.

Proboszcz Michał Dąmbrowski, kanonik katedralny poznański, lat 75, rezydujący na miejscu. Posiadał dyspensę na łączenie kanonikatu, prepozytury w Gniewie i opieki nad kościołem filialnym Tymawa. Do pomocy miał Deodata Arenta, jako zarządce i wikariusza, ale nieobecnego. Poprzednim wikariuszem był Mikołaj Fankidejski, ale odszedł do parafii Śliwice. Organista Walenty Marciński, kościelny Józef Chondzieński. Zakonników nie było. Opinia o parafianach. Wykaz 71 dokumentów w Archiwum Parafialnym się znajdujących. Spis ponad sześćdziesięciu książek liturgicznych, teologicznych i innych, k.96-98.

Opis stanu ekonomicznego parafii i przywilejów, jakimi się cieszyła parafia. Wykaz dochodów i rozchodów, k. 98-98v.

Spis inwentarza żywego i martwego należącego do parafii, k. 99.

Spis paramentów kościelnych wszelkiego rodzaju, bogaty i bardzo dokładny, k. $99 \mathrm{v}-101$.

Spis rzeczy należących do bractwa różańcowego, k. 101-102.

Spis rzeczy należących do bractwa św. Anny, k. 102-102v.

Wizytacja kościoła filialnego w Ty ma w i e. Kościół pod wezwaniem św. Michała Archanioła, prawa patronatu monarszego, zbudowany z pruskiego muru, konsekrowany w 1665 r. Do tego kościoła należą wsie Tymawa, Jazwiska i Rakowiec. Opis świątyni krytej dachówką, posiadającej skromne, ale wystarczające wyposażenie. Relikwii nie było. Odpust na św. Michała. Bractwo św. Rocha. Była szkoła rządowa i uczył w niej Antoni Faustman, katolik. Szpitala nie było. Sakramenty sprawowano tak jak w kościele parafialnym. Opis uposażenia kościoła, pobieranych dziesięcin oraz dochodów i rozchodów. Zabudowania plebańskie bardzo małe i bliskie ruinie. Spis dokładny paramentów liturgicznych, k. 103$103 \mathrm{v}$.

Protokół podpisany przez wizytatora Andrzeja Schulza i notariusza Klińskiego, k. 103v.

Dekret reformacyjny dla kościoła w Gniewie i Tymawie, wystawiony w Gniewie dnia 2 XI 1780 r., k. 104-104v.

Ad M[aiorem] D[ei] Gl[oriam] Beate] V[irginis] M[ariae] Honorem Visitatio Generalis Ill[ustrissi]mi et R[everandis]simi D[omi]ni. Tak rozpoczął się dokładny opis parafii i kościołów w Gniewie i Tymawie, sprządzony zapewne pod dyktando proboszcza i przez niego, to jest Michała Dąmbrowskiego, osobiście podpisany, k. 105-121v.

P ą c z e w o, dekanat gniewski, k. 122. Wykaz tabelaryczny parafii Pączewo. Należały do niej wsie: Pączewo liczące 345 katolików, z czego spowiadających się na Wielkanoc było 247; Wolental 213, 152; Czarnolas 262, 136, Bukowiec 156, 125; Zelgoszcz 255, 158; Wda 140, 95; Młyn Wdeński 9, 8 oraz 14 akatolików; Gęby 11, 7; Cisiny 12, 6; Zadługie 7, 5; Mermet 9, 6; Ziamianek 24, 14; Zajączek 10, 9. Ogółem więc było 1453 katolików, spośród których po spowiedzi 
wielkanocnej było 978, akatolików było zaledwie 14, zaś Żydów nie było, k. $122 \mathrm{v}-123$.

Wizytacja Kościoła parafialnego w Pączewie. Kościół w Poczęcie pod wezwaniem Zwiastowania Najświętszej Marii Panny, murowany, patronatu królewskiego. Opis położenia parafii, k. 124.

Stan świątyni dobry, dachówka wymaga naprawy, wewnątrz ściany dobre, podłoga $\mathrm{z}$ cegły. Dzwonnica murowana, znacznie wyniesiona nad świątynię. Kostnica murowana, cmentarz ogrodzony deskami. Zakrystia posiada wszystko, co potrzebne do liturgii. W świątyni osiem ołtarzy krótko opisanych. Spis obrazów, także tych do procesji. Relikwie św. Stanisława Biskupa i inne. Spis dni z przywilejami odpustowymi. Nie było żadnych osobnych prebend. Bractwo Opatrzności Bożej, za zgoda Stolicy Apostolskiej i władzy diecezjalnej założone. Nie miało własnego uposażenia i utrzymywało się z Jałmużny. Stał na czele bractwa Tomasz Kleinowski. Bractwo miało księgę swoich członków. Role kapelana pełni wikariusz parafii. Osobnych kaplic nie było. W Pączewie szkoła parafialna rządowa, a druga we wsi Zelgoszcz przy kościele filialnym. W Pączewie uczył Jan Szmelcem, w Zelgoszczy zaś Franciszek Knoblau, obydwaj katolicy, ale wynagradzani przez rząd. Przytułek zbudowany z drewna sumptem parafian. Opiekę duchowną ma Proboszcz. Podczas wizytacji wybrano na opiekunów przytułku, gdzie było pięcioro podopiecznych, Michała Grabowskiego z Pączewa i Jakuba Gliński z Wolental, k. 124-126.

Sposób sprawowania sakramentów, k. 126-126v.

Proboszcz Antoni Lewiński, lat 40, Przy parafii rezydował. Duszpasterstwo sprawował przez swojego wikariusza. Miał też parafię Czarnolas, gdzie także miał wikariusza. Sam mało oddawał się duszpasterstwu, chyba iż chodziło o ostatnie sakramenty. Ale ogólnie duszpasterstwo i nabożeństwa nie były zaniedbane. Księgi metryk prowadzono. Krótki wykaz książek ofiarowanych przez proboszcza. Wikariusz Paweł Latoszewich, lat 34., gorliwy. Organista Mateusz Kuczmiński. Zakonników żadnych nie było. Stan obyczajów parafian nie budził większych zastrzeżeń, k. 116v-127v,

Stan ekonomiczny parafii, dziesięciny pobierano, był pewien zapis dawnego proboszcza Jana Babeckiego. Dobrami parafii zarządzał osobiście proboszcz. Wykaz dochodów i rozchodów, k. 127v-128v.

Spis dokładny paramentów kościelnych, w tym także własności bractwa Opatrzności Bożej, k. 128v-130.

Inwentarz własności parafialnej, tak zwierząt, jak i sprzętów oraz opis zabudowań plebańskich, k. 130-131.

Wizytacja kościoła w C z a r n o le s i e, filialnego w parafii Pączewo.

Kościół pod wezwaniem św. Andrzeja Apostoła i św. Mateusza Apostoła i Ewangelisty. Prawo patronatu należało do króla pruskiego. Świątynia z czasów krzyżackich, ale ukończona później, jak na to wskazują ,mury częściowo z kamienia, a nawet pruskiego muru. Stan świątyni dobry. Cmentarz dobrze utrzymany $\mathrm{z}$ kostnicą. Innowierca młynarz na swoim gruncie urządził cmentarz dla swoich postawił tam Krzyż, k. 131v-132. 
Spis paramentów liturgicznych, dosyć bogaty jak na kościół filialny. Ołtarzy było siedem, wystarczająco opisanych. Opis obrazów. Zakonników żadnych nie było Nie było też relikwii. Wykaz przywilejów odpustowych. Bractwo św. Józefa, Oblubieńca Najświętszej Marii Panny, bez własnego uposażenia, utrzymujące się z jałmużny. Ale posiadało swój ołtarz i paramenty liturgiczne, k. 132-133v.

Sakramenty sprawowano tak, jak w świątyni parafialnej, k. 133v.

Stan ekonomiczny oraz stan zabudowań plebańskich, w stanie kiepskim i bez żadnego inwentarza, k. $133 \mathrm{v}-124$.

Protokół powizytacyjny wystawiony w Pączewie dnia 15 XI 1780 r., podpisany przez wizytatora Andrzeja Józefa Schulza i notariusza Jana Klińskiego, k. 134.

Dekret reformacyjny dla parafii Pączewie i dla kościoła filialnego w Czarnolesie, spisany w Pączewie dnia 15 XI 1780 r., k. 134v-135.

Wykaz tabelaryczny parafii Pączewo ${ }^{72}$, k. $135 \mathrm{v}-136$.

Wizytacja generalna kościoła filialnego w Czarnolesie ${ }^{73}$, k. 137-140.

P i a s e c z n o-dekanat gniewski. Wykaz tabelaryczny parafii Piaseczno. Do parafii należały wsie: Piaseczno liczące 296 katolików, z czego po spowiedzi wielkanocnej były 221 osoby, akatolików nie było; Jelenie odpowiednio 162, 12o i 3 akatolików, Bielsk 91, 70; 10; Wyręby 82, 62; Wyrębki 5, 32. Ogółem w przy tym kościele było 606 katolików, z czego spowiadających się 505 oraz mieszkało 13 akatolików, k. 141v-142.

Wykaz tabelaryczny kościoła filialnego, dla parafii Piaseczno, we wsi Opalenie. Należały do niego wsie: Opalenie w której było katolików 61, w tym spowiadających się na Wielkanoc 46 oraz mieszkało 34 akatolików; Misterwald odpowiednio 92, 71 i27; Widlice 30, 21 i 52; Dębowy Las 35, 22 i 21; Wielkie i Małe Aplinki 16, 14, 56; Przewóz Misterwaldzki 16, 12 , i 8. Ogółem, zatem w tej części parafii było 250 katolików, spośród których spowiadało się 186 oraz mieszkało 186 akatolików, k. 141v-142.

Wizytacja kościoła parafialnego w Piasecznie. Świątynia murowana pod wezwaniem Narodzenia Najświętszej Marii Panny, patronatu królewskiego. Opis jej położenia. Wsie parafialne tak, jak w wykazie tabelarycznym. Świątynia murowana, w stanie dobrym z dwiema kaplicami od północy św. Józefa w 1755 r. złączona ze świątynią [pewnie chodzi tu o remont], i druga, po stronie przeciwnej, należąca do bractwa Szkaplerza, w $1758 \mathrm{r}$ też złączona z murem i dachem świątyni ${ }^{74}$. Opis stanu świątyni, częściowo ze sklepieniem murowanym, także nad kaplicami oraz z grobowcami. Dzwonnica, złączona ze świątynią, została nadmurowana w 1748 r. Dalszy opis wystroju zewnętrznego i wewnętrznego świątyni. Ołtarzy było dziewięć. W wielkim znajdowała się figura Matki Boskiej, słynąca łaskami. Na wieży znajdował się zegar wybijający godziny. Cmentarz przykościelny. Przy wejściu do świątyni znajdowała się trzecia kaplica murowana. Relikwii posobnych nie było. Prebend osobnych nie było. Z zapisu księcia Radziwiłła z 1648 r.,

\footnotetext{
${ }^{72}$ Jest to wykaz identyczny z wykazem na kartach $122 \mathrm{v}-123$.

${ }^{73}$ Tekst tego zapisu w pełni zgadza się z tym, co napisani na kartach 131v-134 przy opisie kościoła filialnego w Czarnolasie, parafii Pączewo.

${ }^{74}$ Chodziło tu zapewne o remonty tak świątyni jak i kaplic.
} 
kanclerza księstwa litewskiego, odmawiano oficjum o Matce Bożej w każdą sobotę. Bractwo Szkaplerza, za wiedzą Stolicy Apostolskiej zaprowadzone w 1640 r. Prowadzono księgę członków bractwa, a także dochodów i rozchodów, ale własnego uposażenia nie posiadano. Kaplic publicznych nie było. Na terenie parafii mieszkało 6 osób innej religii we wsi Bielsk. Szkoły nie było, ale mógł uczyć organista, jednakże aktualnie żadnego ucznia nie było. Przytułek stojący przy kościele nie posiadał wystarczającego uposażenia i ubodzy utrzymywali się z samej jałmużny, k. 143-144v.

Sposób sprawowania sakramentów, k. 143v.

Proboszcz Adam Niesiołowski, liczący lat 80, rezydujący przy parafii. Posiada jeszcze afiliowaną parafię w Opaleniu. Opis sprawowanego nabożeństwa i duszpasterstwa. Podano tu także wysokość opłat za posługę duszpasterską. Obok ksiag parafialnych, prowadzono także księgę wotów srebrnych przy łaskimi słynącej figurze matki Boskiej. Wikariusz Ignacy Gręca. Organista Andrzej Kosecki, Zakrystian Jakub Stempa. Żadnych zakonników nie było. Parafianie, na ile ułomność ludzka pozwalała, wiedli życie spokojne. W Wielkim Poście, w niedzielę, po wysłuchaniu kazania pasyjnego i wystawionym Najświętszym Sakramencie w Puszcze, biczowali się, bez śmiechu, ale ze skruchą ${ }^{75}, \mathrm{k} .144 \mathrm{v}-145 \mathrm{v}$.

Stan ekonomiczny parafii, na utrzymanie, której była ziemia i pewne zapisy, tu wyliczone. W 1748 r. Proboszcz własnym sumptem wystawił przytułek. Nie oddawano już dziesięciny snopowej, ale w zbożu. Wykaz dochodów i rozchodów, k. $145 \mathrm{v}-147$.

Spis dokładny paramentów liturgicznych, szat i innych rzeczy, a także książek liturgicznych. Poprzednie wizytacje zamieszczały katalog ksiąg bibliotecznych, k. $147-150 v$.

Spis rzeczy posiadanych przez bractwo Matki Bożej z Góry Karmel, czyli Szkaplerznej, k. 150v-151.

Inwentarz gospodarski, zwierząt i sprzętu, a także opis stany zabudowań plebańskich, k. 151.

Opis mieszkania organisty i kościelnego, k. 151v.

Opisy cudownych zdarzeń zdziałanych za wstawiennictwem Matki Boskiej Piaseczyńskiej, sporządzone 24 VII 1649 r. przez biskupa kujawsko-pomorskiego Wojciecha Gniewosza, k. 151v.

Wykaz wotów srebrnych i złotych składanych w Piasecznie, k. 152.

Dekret reformacyjny dla parafii Piaseczno i dla kościoła w Opaleniu, wystawiony w Piasecznie dnia 9 XI 1780 r., k. 153-154.

Wizytacja kościoła w O p a 1 e n i u, afiliowanego do parafii Piaseczno.

Kościół filialny pod wezwaniem świętych Apostołów Piotra i Pawła, murowany, fundowany w $1771 \mathrm{r}$. przez Jakuba Czapskiego, podskarbiego pruskiego, na miejscu poprzedniego $\mathrm{z}$ pruskiego muru wystawionego. O początkach poprzedniej świątyni nic nie wiadomo. Nowa jeszcze nie konsekrowana ani poświęcona. Prawo patronatu należało do króla. Opis położenia tej „parafii”. Wsie należące to

\footnotetext{
${ }^{75}$ Nie zawsze o tym zwyczaju pisano w protokołach wizytacyjnych.
} 
Opalenie, Misterwald, Widlice, Las Topolowy, Aplinki Wielkie, Aplinki Małe, Przewóz i Karczma Przewozowa ${ }^{76}$. Wymienione wsie tworzą właściwie jeden cią, jedna wieś się kończy, a zaczyna druga, k. 155.

Kościół murowany z podaniem wielkości w łokciach. Nowy, a więc jeszcze nie całkowicie ukończony. Dosyć dokładny opis wyglądu. W kościele są trzy ołtarze. Opis obrazów. Były relikwie, które po śmierci fundatora z pałacu zostały przeniesione do kościoła. Opis przywilejów odpustowych. Bractwo św. Józefa w 1748 r. zaprowadzone. Opiekowało się ołtarzem św. Józefa. Miało księgę swoich członków, księgę inwentarza oraz mszy świętych. Szkoły nie było, k. 155156.

Sposób sprawowania sakramentów, k1. 156-157.

Stan ekonomiczny, k. 156v.

Spis paramentów kościelnych, k. 156v-157.

Opis stany domy plebańskiego i innych budynków, k. 157v.

Protokół powizytacyjny dla parafii Piaseczno i dla kościoła filialnego, sporządzony w Piasecznie dnia 9 XI 1780 r., podpisany przez wizytatora Andrzeja Schulza i notariusza Klińskiego, k. 157v.

Opis kościoła w Piasecznie i Opaleniu [w] roku 178177, k. 158.

Wizytacja kościoła parafialnego w Piasecznie. Jest to opis parafii sporządzony przez proboszcza Księdza Adama Gawin Niesiołowskiego, z jego osobistym podpisem, zgadzający się, z opisanym powyżej na kartach 143-152 protokółem wizytacyjnym, k.159-162v.

Wizytacja kościoła filialnego Opalenie. Jest to opis tego kościoła, sporządzony przez proboszcza księdza Adama Gawin Niesiołowskiego, z jego osobistym podpisem, zgadzający się z protokółem wizytacyjnym zamieszczonym w księdze na kartach 155-157v, opisanym powyżej, k. 163-163v.

Li g n o w y ${ }^{78}$, dekanat gniewski, k. 164. Wykaz tabelaryczny parafii Lignowy. Do parafii należały następujące wsie: Lignowy, gdzie było 343 katolików, z czego spowiadających się na Wielkanoc 206mosób, zaś akatolików naliczono na terenie parafii 126 osób; Szprudowo 155, 118, 70; Kursztyn 1123, 85, 89; Janikowo 138, 100, 12; Pomyje 137, 106, 7, Młynek gdzie mieszkało jedynie 8 akatolików. Czyli razem w parafii było 896 wiernych z czego spowiadających się było 615 osób, a innowierców zamieszkiwało 312 osób, k. 164v-165.

Wizytacja kościoła parafialnego Lignowy. Kościół pod wezwaniem św. Marcina i św. Małgorzaty. Prawo patronatu należało do króla pruskiego. Opis położenia parafii. Wieś Lignowy aktualnie znajdowała się w posiadaniu wojewody pruskiego Czartoryskiego. Świątynia murowana, prezbiterium ze sklepieniem murowanym, nawa zaś miała sufit drewniany. W nawie grobowiec murowany. Dalszy

\footnotetext{
${ }^{76}$ Ten wykaz nieco różni się od tego z wykazu tabelarycznego.

${ }^{77}$ Data zapisana w tym kontekście nie zgadza się z datą zapisaną w protokóle wizytacji.

${ }^{78} \mathrm{~W}$ księdze nazwę tej parafii pisano Libnowy.
} 
opis kościoła, który miał częściowo potłuczone okna i dach zaciekający. Cmentarz niezbyt dobrze ogrodzony z wydzielonym miejscem na chowanie innowierców. Zakrystia zaopatrzona we wszystko, co potrzebne do liturgii. Opis trzech ołtarzy i obrazów. Relikwie św. Marcina oraz innych świętych, ale bez dokumentu autentyczności. Przywileje odpustowe. Osobnej prebendy i beneficjum nie było. Bractwo Różańcowe, posiadające swoje księgi. Posiadało zapis 1000 florenów, uczyniony przez dawnego proboszcza Karola Janowskiego, zabezpieczony na mieście Gniew. Kaplic żadnych na terenie parafii nie było. Szkoła prowadzona przez dysydentów protestant ów, k. 166-166v.

Sposób sprawowania sakramentów, k. 166v-167.

Po rezygnacji krótko przez wizytacja dotychczasowego proboszcza Stefana Antoniewicza, kanonika włocławskiego, parafia wakowała, ale był już naznaczony na następcę wikariusz niepodanego imienia Michnowski. Organista Jan Zblewski, Witrykusami byli dwaj wieśniacy wyznania protestanckiego, k. 167.

Stan ekonomiczny parafii z podaniem pobieranego mesznego oraz wykazy dochodów i rozchodów, k. 167-167v.

Spis paramentów kościelnych, z osobnym spisem rzeczy należących do bractwa, k. 168-168v.

Opis budynków plebańskich. Plebania wystawiona przez parafian innowierców, pozostałe zaś budynki zniszczone za poprzedniego proboszcza. Organistówka z bardzo złym stanie, czego parafianie nie chcą poprawić. Podano jakie wynagrodzenie pobierał organista, $\mathrm{k}$. $` 168 \mathrm{v}$.

Wizytacja kościoła s z p r u d o w s k i e g o, afiliowanego do parafii Lignowy.

Świątynia pod wezwaniem św. Szymona i Judy Apostołów, według podania fundowana niegdyś przez sołtysa szprudowskiego, murowana, nigdy nie konsekrowana, przedstawiająca stan ruiny. Wieś Szprudowo należy do króla. Katolików należy 155, do komunii zobowiązanych było 118 osób, akatolików mieszkało 70 . Opis świątyni przedstawiającej stan zgoła zły. Cmentarz przykościelny nie był ogrodzony. Nie było naczyń liturgicznych i do mszy używano z kościoła macierzystego. Wykaz pozostałych paramentów liturgicznych, bardzo skromny, Dwa ołtarze. Nie było relikwii. Przywileje odpustowe. Nie było prebend, czy beneficjów osobnych, a nawet żadnego bractwa. Na cmentarzu chowają się dysydenci. Sakramenty sprawowane tak jak w kościele macierzystym. Najświętszego Sakramentu nie przechowuje się. Ofiary składane do skarbony dla bezpieczeństwa są przechowywane u sołtysa. Nie było żadnych zabudowań dla proboszcza i organisty, k. 169-169v, 171.

Dekret reformacyjny dla kościoła macierzystego lipnowskiego i filialnego szprudowskiego, gdzie jest mowa o bardzo złym położeniu i wyrażający nadzieje na odnowienie parafii, wystawiony w Lignowych dnia 28 XI $1780 \mathrm{r}^{79}, \mathrm{k} .170$.

Protokół powizytacyjny wystawiony w parafii Lignowych dnia 28 X $1780 \mathrm{r}$., podpisany przez wizytatora Andrzeja Schulza i notariusza Jana Klińskiego, k. 171.

${ }^{79}$ Dekret reformacyjny umieszczony pomiędzy częścią protokołu wizytacyjnego na kartach 159-159v i jego zakończeniem na karcie 171. 
Wizytacja kościoła parafialnego w Lignowych. Opis parafii, z tabelą całkowicie zgodną z tą z kart 164v-165. Podaje więcej szczegółów. Między innymi podaje, że proboszczem był Jan Trebbels, eksjezuita, na probostwo instytuowany 14 I 1781 r., ale częściej rezydujący przy kaplicy królewskiej w Gdańsku. Opis sprawowanego przezeń duszpasterstwa. Wikariuszem był Józef Landzberg od 20 II 1781 r.. Ten opis nie został przez nikogo podpisany, można domniemywać, że sporządzony został już w 1781 r., po nominacji nowego proboszcza i wikariusza, k. $172-182$ v.

Wizytacja kościoła filialnego szprudowskiego, także dokładniejszy opis aniżeli w samym protokóle wizytacyjnym, zapewne sporządzony przez wikariusza w parafii Lignowy, ale podpisu brak, k. 183-187.

W a 1 i c h n o w y, dekanat gniewski, k. 188. Wykaz tabelaryczny parafii Walichnowy. Należały do parafii wsie: Wielkie Walichnowy idące 228 katolików, spośród których 200 spowiadało się na Wielkanoc oraz na terenie parafii mieszkało 75 akatolików; Małe Walichnowy 54, 30, 134; Rozgarty 202, 180, 41, Kuchnia $31,15,68$. Razem wić było 512 katolików, spowiadających się 425 oraz 318 akatolików, k. $188 \mathrm{v}-189$.

Wizytacja kościoła parafialnego w Walichnowach. Kościół we wsi Wielkie Walichnowy, pod wezwaniem św. Jana Chrzciciela, prawa patronatu monarszego. Opis położenia parafii. Świątynia bardzo zniszczona i dosyć dokładnie opisana. Była zaopatrzona we wszystko, co potrzebne do liturgii. Trzy ołtarze. Relikwie i przywileje odpustowe. Osobnych prebend nie było. Bractwa, kaplic zadnich nie było. Zamiast szkoły, organista uczył podstaw nauko około 20 uczniów, k. 190-191.

Sposób sprawowania sakramentów, k. 191-191v.

Proboszcz Kajetan Rembieliński, pochodzący z Pomorza, lat 36, zakonnik jezuita. Innej parafii nie posiadał. Kazania głosił wikariusz, proboszcz trzy razy w roku, albo gdy nie było wikariusza. Opis sprawowanych nabożeństw. Wikariusz Walerian Pernarewski, lat 28, z pochodzenia Litwin Organista Paweł Kurczewski. Parafianie nie przysparzali większych kłopotów, k.192-193.

Stan ekonomiczny parafii z wykazem dochodów i rozchodów, 1. 193-194.

Inwentarz paramentów liturgicznych z wykazem ksiąg kościelnych, k. 194$-195 \mathrm{v}$.

Opis zabudowań plebańskich oraz inwentarz gospodarski, k. 195v.

Protokół podpisany w Walichnowach przez wizytatora Andrzeja Józefa Schultza i notariusza Jana Klińskiego dnia 14 X 1780 r., k. 195v.

Dekret reformacyjny z 24 X 1780 r., k. 196-196v.

Wykaz tabelaryczny parafii dosłowny jak na k. $188 \mathrm{v}-189$.

Drugi opis parafii, zgodny z tym, co napisano w protokóle wizytacyjnym. Nie podano, kto go sporządził, ale wzorem innych parafii można się domyślać, że to proboszcz, k. 198-205v.

Odpis dokumentu z dnia 27 VII 1764 r., dotyczącego sporu pomiędzy proboszczem w Walichnowych, a niektórymi parafianami odnoszącego się do obowiązku naprawy zabudowań parafialnych, k. 206-207v. 
R a j k o w y, dekanat gniewski, k. 208. Wykaz tabelaryczny parafii Rajkowy. Obejmowała ona jedynie wieś Rajkowy, gdzie było 387 katolików, z czego spowiadało się na Wielkanoc 317 osób. Ponadto było 9 akatolików, oraz Młyn Walichnowski, gdzie mieszkało odpowiednio 8 i 6 osób. Zatem ogólnie było 397 katolików, 323 spowiadających się. Akatolików 9, a Żydów nie było, k. 208b-209 .

Wizytacja kościoła parafialnego w Rajkowach. Świątynia pod wezwaniem św. Bartłomieja Apostoła, prawa patronatu monarszego. Opis położenia parafii. Kiedy powstała dawna świątynia niewiadomo? Obecna świątynia murowana zbudowana przed około 70 laty przez proboszcza Rajkowskiego Jana Rowkiewicza, konsekrowana przez biskupa sufragana włocławskiego Bardzińskiego ${ }^{80}$. Opis nowej świątyni, murowanej i solidnej, krytej dachówką. Opis otoczenia świątyni, ale ogrodzenie murowane w kilku miejscach uszkodzone, k. 210.

Spis paramentów liturgicznych. W świątyni trzy ołtarze. Kościół posiadał relikwie i przywileje odpustowe. Bractwo różańcowe zaprowadzone przez dominikanów, posiadających nieco swoich szat liturgicznych oraz zapis 500 florenów, przez niejakiego mincarza Krzysztofa Freychel z Rajkowych i lokowanych na wsi Szprudowo. Kaplic żadnych nie było. Przytułku nie było. Szkoła była i uczył nauczyciel, człowiek świecki, opłacany prze rząd, który w szkole parafialnej dawał podstawy wiary i nauki, k. 210-211v.

Sposób sprawowania sakramentów, k. 211v-212.

Proboszcz Michał Łabuszewski, lat 45, urodzony na Pomorzu, w parafii zawsze rezydujący i sam sprawujący duszpasterstwo, k. 211v-212.

Spis książek. Zakonników w parafii nie było. Stan moralny parafian nie budził zastrzeżeń, k. 212.

Stan ekonomiczny parafian. Wykaz dochodów i rozchodów. Inwentarz żywy i martwy. Opis uposażenia organisty, k. 212-213.

Protokół podpisany w Rajkowach dnia 24 X 1780 r., podpisany przesz wizytatora Schulza i notariusza Klińskiego, k. 213.

Wykaz tabelaryczny, identyczny z tym z karty $208 \mathrm{v}-209$.

Dekret reformacyjny wystawiony w Rajkowach 24 X 1780 r.

Wizytacja generalna parafii Rajkowy. Jest to dokładny opis parafii, zgodny z poprzednim protokółem wizytacyjnym, sporządzony przez proboszcza Michała Łabuszewskiego i przezeń podpisany, k. 215-223v.

P e 1 p 1 i n, dekanat gniewski, k. 224. Wykaz tabelaryczny parafii Pelplin. Należała do niej wieś Pelplin, licząca katolików 308, w tym spowiadających się na Wielkanoc 279 oraz 10 akatolików. W drugiej wsi Wola były odpowiednio 14, 10 i 3 osoby. Zatem ogółem parafia liczyła 322 wiernych, z czego spowiadało się 289 oraz mieszkało 13 akatolików, k. 224v-225.

Wizytacja kościoła parafialnego w Pelplinie, k. 226.

${ }^{80}$ Biogram tego sufragana zob. Chodyński, Biskupi sufragani włocławscy, Włocławek 1906, s. 67-69. 
Świątynia w Pelplinie pod wezwaniem Bożego Ciała, prawa patronatu zakonników, bowiem opat mianuje dobrowolnie jednego z zakonników proboszczem. Świątyni murowana, konsekrowana przez sufragana włocławskiego w 1418 r. Opis położenia parafii. Świątynia ta była fundowana razem z klasztorem przez księcia Sambora. Opis stanu tej świątyni murowanej. Zakrystia wystarczająco zaopatrzona. Pięć ołtarzy dobrze opisanych oraz obrazy. Dwa relikwiarze4 i przywileje odpustowe. Bractwo Aniołów Stróżów zaprowadzone w 1638 r. z przywileju papieża Urbana VIII, posiadające swoje ksieggi brackie oraz niektóre paramenty liturgiczne. W szkole uczył organista dający podstawy wiary i pisania. Przytułek przy kościele, bez żadnej fundacji, ale ubogich karmi i zaopatruje klasztor, k. 227-227v.

Sposób sprawowania sakramentów, k. 227.

Obowiązki proboszcza spełniał Gwilhelmus Kostrzewski, zakonnik cysterski. Kazania bywały po polsku i po niemiecku. Na terenie parafii w klasztorze cysterskim przebywało 37 zakonników, ale ci mieli swojego wizytatora. Osobnego uposażenia parafii nie było, ponieważ proboszcz mieszkał i żywił się razem z zakonnikami, k 227v-228.

Spis inwentarza i paramentów liturgicznych, k. 228-229v.

Protokół podpisany w Pelplinie 21 [X] 1780 r., przez wizytatora Schultza i notariusza Klińskiego, k. 229v.

Dekret reformacyjny wystawiony w Pelplinie 21 X 1780 r., k. 230.

Wykaz tabelaryczny parafii Pelplin całkowicie zgodny z tym z kart 224v-225, k. $230 \mathrm{v}-231$.

Wizytacja kościoła parafialnego w Pelplinie. Opis bardzo dokładny i przejrzysty, zgodny z powyższym, sporządzony przez Gwillelma ${ }^{81}$ Kostrzewskiego, zakonnika cystersów pelplińskich, k. 232-235v.

D z i e r z ą ż n o, dekanat gniewski, k. 236. Wykaz tabelaryczny parafii Dzierzążno. Obejmowała ona wsie: Dzierzążno liczące 139 katolików, z tego 103 spowiadających się oraz mieszkało 14 akatolików, wieś Gogolewo odpowiednio 178, 146 i 10; Polskie Brody 51, 39 i 18, Młyn, czyli Stawska karczma 15, 11, 4, co razem dawało 383 wiernych, z czego spowiadało się 289 osób oraz mieszkało 46 akatolików, k. 236v-237.

Wizytacja kościoła parafialnego w Dzierzążnie. Opis kościoła według położenia i stanu. Świątynia, jak głosi podanie miała być tu zbudowana w 1001 r., lub, co najmniej w 1096 r., ale przez kogo, nie wiadomo. Nosi wezwaniem św. Jakuba Apostoła. Prawo patronatu należało do kapituły włocławskiej, z prezbiterium nowo murowanym, zaś dzwonnica z muru pruskiego. Stan świątyni dobry. W świątyni grobowiec Konstancji Starzyńskiej. Cmentarz nie był całkowicie ogrodzony. Zakrystia wystarczająca zaopatrzona w potrzebne paramenta liturgiczne i księgi. Trzy ołtarze. Relikwii nie było. Żadnej kaplicy, prebendy czy osobnego beneficjum nie było, podobnie jak szkoły, czy przytułku. Jedynie organista uczył podstaw wiary i czytania. Ubodzy mieszkają w domach parafian, k. 238-238v.

Sposób sprawowania sakramentów, k. 238v-239.

${ }^{81}$ Tak dokładnie napisano to imię. 
Zarządca parafii od 1773 r. jest, prezentowany przez kapitułę włocławską, Daniel Józef Postell, lat 34. Nie jest proboszczem, bo nie złożył wymaganego homagium i opłaty. Duszpasterstwo sprawował osobiście, jedynie na święto św. Jakuba przybywali inni kapłani. Posiadał sporo książek, które zadeklarował zostawić po swojej śmierci dla parafii Dzierzążno. Zakonników nie było. Stan moralny parafian nie budził większych zastrzeżeń., k. 239.Stan ekonomiczny parafii i wykaz dochodów i wydatków, k. 239v.

Spis dokładny paramentów liturgicznych, naczyń, szat i innego sprzętu kościelnego, , k. 239v-241,

Inwentarz gospodarczy, żywy i martwy, z wykazem zasiewów zboża. Opis zabudowań plebańskich, k. 241-241v.

Protokół podpisany w Dzierzążnie, dnia 4 XI 1780 r. przez wizytatora Schulza i notariusza Klińskiego, k. 241v.

Dekret reformacyjny dla parafii, wystawiony w Dzierzążnie dnia 4 XI 1780 r., k. 242.

Wykaz tabelaryczny parafii Dzierzążno, identyczny z tym z kart 236v-237.

Wizytacja kościoła parafialnego Dzierzążna. Dodatkowo podano tu wiadomość, iż w świątyni tej w 1739 r. został pochowany ówczesny Proboszcz Maciej Tadeusz Latoszewicz. Pozostałe wiadomości zgadzają się z protokółem powyżej przedstawionym. Opis ten podpisał osobiście ksiądz Daniel Postell, zarządca parafii Dzierzążna, k. 244-249v.

Wizytacja dekanatu nowskiego, diecezji pomorskiej.

Opis dekanatu nowomiejskiego (nowskiego), obejmującego 11 parafii, a mianowicie w Nowe, Komórsk, Lubień, Bzowo, Płochocin, Jania (Kościelna Jania), Lalkowy, Barłożno, Skórcz, Pieniążkowi i Grabowo. W Nowem ponadto był kościół szpitalny w. Jerzego. Opis położenia poszczególnych parafii. Dziekanem był Jan Łabiński, lat 41, kanonik kruszwicki, proboszcz ze Skórcza i zarządca parafii Grabowo. Dziekanem jest od 1774 r. Przeprowadzał wizytacje dekanatu. Asesorami w dekanacie byli Andrzej Dobrowolski, Proboszcz z Barłożna i Jan Halba Proboszcz z Jani. Notariuszem był proboszcz z Płochocina, ksiądz Michał Rączkowski. Charakterystyka jego działalności dziekańskiej. Wizytator pytał go o problemy dotyczące wizytowanego dekanatu. Podpisał wizytator Andrzej Józef Schulz, kanonik kruszwicki, dziekan z Tczewa, proboszcz z Kiszewa, wizytatora generalny, k. 250-250v.

S k ó r c z. Wykaz tabelaryczny parafii Skórcz. Wieś Skórcz liczyła wiernych 396, spowiadających się 236 i 1 akatolika, Wielbrądowo odpowiednio 227, 148, -; Wycinki 40, 23, 6; Wymysłowi 5, 5,-; Radogoszcz 22, 10, -; Trzebiechowo 5, 4, -; Dębiegóry 7, 4, -; Łuby 11, 5, _; Pieczyska 5, 4, -; Sucha Brzeźnica 18, 10, -; Błędno 7, 4, 4; Kasperus 94, 77, -; Szlaga 13, 8, 6; Skrzynia 9.8, -; Kozie 34, 28, -; Głucha 10,9, -; Karszenek 24, 17, 8; Wierzbiny 12, 7, -; Zajączek 25, 17, -; Ci- 
siny 11, 5, -; Grabowo, gdzie jest kościół filialny, 182, 131, -; Osiek, gdzie jest kaplica publiczna $202,112,15$. zatem ogólnie wiernych było 1382, spowiadających się 894, zaś akatolików mieszkało 40 osób, k. 250v-251.

Wizytacja kościoła parafialnego w Skórczu. Świątynia pod wezwaniem Wszystkich Świętych, prawa patronatu monarszego. Opis położenia parafii. Kościół pochodził z Czasów krzyżackich. Zbudowany z solidnego muru, a znaki pozwalają twierdzić, że był konsekrowany. Zewnętrzny stan dobry, ale wewnątrz świątynia wymagała wybielenia. Sklepienie z desek złe. Dokładny opis stan świątyni. Zakrystia ze sklepieniem murowanym. Dach z dachówki. Zakrystia wystarczająco zaopatrzona w potrzebne rzeczy. W świątyni trzy ołtarze. Relikwie św. Konstancji z dokumentem autentyczności. Przywileje odpustowe. Osobnych prebend ani beneficjów nie było. Bractwo Niepokalanego Poczęcia Najświętszej Marii Panny w 1586 r. założone z przywileju papieża Innocentego XI. Posiadało swoje uposażenie. Kaplica publiczna we wsi Osiek, gdzie za czasów polskich było starostwo. Spis paramentów liturgicznych, a więc naczyń i ornatów. Akatolicy chowają się na cmentarzy przy tej kaplicy, a nawet pochowali w niej dwóch swoich duchownych. Szkoły publicznej czy parafialnej nie było, ale organista uczył około 30 dzieci obojga płci, k. 252-253v.

Sposób sprawowania sakramentów, k. 253v.

Proboszczem aktualnie był Jan Łabiński, kanoniki kruszwicki i dziekan nowski, w parafii zawsze rezydujący. Opis sprawowanych nabożeństw. Księgi wszystkie prowadził. Wykaz książek proboszcza i będących własnością parafii. Wikariuszem był Antoni Guziński, pochodzący Pomorza, lat 42. Organista, chorujący od trzech lat, Piotr Żelewski. Witrykusami byli Florian Szpada, Paweł Mosieński i Andrzej Kitowski. Żadnych zakonników nie było. Opinia o parafianach, gdzie zdarzały się przypadki niedociagnięć, k. 253v-254v.

Stan ekonomiczny parafii. Pobierano jeszcze dziesięcinę snopowa i w pieniądzu. Wykaz wsi oddających dziesięcinę. Na utrzymanie świątyni też były osobne dochody, tu wyliczone. Także bractwo posiadało dochód z łanu ziemi. Wykaz dochodów i rozchodów, k. 254v-255v.

Inwentarz rzeczy kościelnych, a więc srebrnych i innych naczyń liturgicznych, ornatów, kap, choragwi, obrazów. Wykaz własności bractwa, k. 256-257.

Stan zabudowań plebańskich oraz domu organisty. Przytułek w ruinie, ale rządca kościoła i parafianie zapowiadają jego odbudowę, k. 257.

Wizytacja kościoła filialnego w G r a b o w i e. Świątynia pod wezwaniem św. Marii Magdaleny, zbudowana z pruskiego muru, kryta dachówka. Opis dosyć dokładny świątyni i jej otoczenia. Zakrystia wyposażona we wszystko, co potrzebne do nabożeństw, ale nie było zbyt dobrze się prezentujące. Ołtarze cztery. Relikwii nie było. Nie było na terenie podlegającym temu kościołowi filialnemu żadnych prebend, beneficjów osobnych, szkoły czy przytułku, k. 257v-258.

Stan ekonomiczny przedstawiał się bogato, bo należało 6 łanów ziemi, będących w dzierżawie, oraz były doimy dające także pewien dochód. Witrykusami byli sołtys Jakub Prabucki i Wojciech Cieśliński, k. 258.

Spis paramentów liturgicznych przy tym kościele się znajdujących, k. 258. 
Protokół podpisany w Skórczu przez wizytatora Schulza i notariusza Klińskiego dnia 23 II 1781 r., k. 258-258v.

Dekret reformacyjny dla parafii Skórcz i dla kościoła filialnego w Grabowie, wystawiony w Skórczu dnia 23 II 1781 r., k. 258v-259.

Kościół parafialny w Skórczu - jego stan i położenie, dalej opis kościoła filialnego w Grabowie oraz kaplicy publicznej w Osieku, bardzo dokładnie, nawet bardziej aniżeli w samym protokole wizytacyjnym, opisane przez proboszcza Jana Antoniego Łabińskiego i przez niego osobiście podpisane, k. 260-269v.

Miasto N o w e, dekanat nowski, k. 270. Wykaz tabelaryczny parafii Nowe. Do parafii należało najpierw miasto Nowe liczące wiernych katolików 338, z czego spowiadających się 238, akatolików 436 oraz 150 Żydów. Żydzi byli jedynie w mieście. Do parafii należały dalej Przedmieście liczące odpowiednio 178, 118 i 15; Sady 74, 43, 169; Wolnoście 6, 3, 12; Konczyce 60, 47, 16; Rybaki 80, 61, 24; Zdroje gdzie było jedynie 90 akatolików; Morgi 6, 5, 225; Kwiatek, 75 akatolików; Osiny 140 akatolików; Głodowo 5, 5, 88; Ciemnylas 10, 6, 4; Zabijak 4, 4; -; Muntasek 10, 9, 13; Recice tylko 10 akatolików; Blizany 9 akatolików; Tryll Wielki 5, 5, 289; Tryll Mały jedynie 80 akatolików; kamionka 103, 70, 17; Rychława 5, 5, 198; Kozielec 116, 80, 11; Bocklin 80, 49, 9; Mieliwko 6, 5, 160; Mieliwe 57, 37, 10; Zawada 26, 19, -; Karczemka 49, 42, 6; Łąbętki 19, 9, -; Białebłotki gdzie mieszkało jedynie 15 akatolików. W całej zatem parafii było 1243 katolików, z czego spowiadało się na Wielkanoc 864 osoby, akatolików mieszkało 2161 oraz 150 Żydów, k. 270v-271.

Wizytacja kościoła w Nowem, Świątynia w Nowem pod wezwaniem św. Mateusza Ewangelisty, pod patronatem monarszym. Opis położenia parafii. Według protokołu dawnej wizytacji, miała zostać wzniesiona ta murowana świątynia w 1105 r. przez księcia pomorskiego Przybysława. Wymieniono tu miejscowości parafialne, tak jak w wyżej podanej tabeli. Aktualnie ten kościół zbudowany z murów, znajduje się w stanie zagrażającym bezpieczeństwu, bo mury porysowane, dach zepsuty, a części drewniane zniszczone i wszystko wymaga pilnej naprawy. Opis wnętrza świątyni, gdzie okna nieszczelne. Wyposażenie też znacznie podniszczone. Dwa grobowce rodziny Konopackich i drugi mieszczan. Dzwonnica mocna z dzwonami, które są s dużej mierze uszkodzone. Cmentarz ogrodzony, ale niezbyt dokładnie, gdzie chowa się zmarłych. Przy kościele św. Jerzego też jest miejsce pochówków. W zakrystii jest wszystko, co potrzebne, ale nie wszystko jest w porządku. Opis sprzętów w kościele. Sześć ołtarzy, tu opisanych, a niektórymi opiekują się cechy lub bractwa. Relikwie św. Mateusza Apostoła i ewangelisty. Bractwo Różańcowe zaprowadzone w 1641 r. oraz bractwo Najświętszego Imienia Jezus z 11716 r. Z nich bractwo Różańcowe posiadało swoje i to dosyć duże uposażenie. Obydwa bractwa prowadziły księgi swoich statutów, członków, a także dochodów i wydatków. Na przedmieściu stal kościół św. Jerzego. Innych nie było. Akatolicy mają swoją kaplicę w ratuszu, a na przedmieściu swój cmentarz. Żydzi w jednym z domów urządzili swoją synagogę, ale nie mają cmentarza. Szkoły nie było, ale niejaka Jadwiga Stołowska w jednym z pomieszczeń przytuł- 
ku, zwanego konwentem, uczyła około 50 dzieci obojga płci. Wspomniany przytułek dla mieszczan obojga płci, gdzie przebywały aktualnie trzy osoby, miał swoje uposażenie, k. 272-273v.

Sposób sprawowania sakramentów, k. 273v-274.

Proboszcz Andrzej Chaliński, pochodzący z ziemi dobrzyńskiej, kanonik płocki, lat 54, ale w parafii nierezydujący, bo miał jeszcze parafie Biała koło Płocka, ale mający tu zarządcę. Opis nabożeństw. Wikariuszem zarządca był Józef Kitowski, z Pomorza pochodzący, dobrze spełniający swoje obowiązki. Organista Franciszek Zurewski, Zakrystianin i dzwonnik Michał Schmyt. W parafii był klasztor franciszkanów reformatów, gdzie było 18 zakonników. Podano tu wiadomości o współpracy parafii i klasztoru. Parafianie przykazania zachowują i nie było publicznych grzeszników, k. 274-274v.

Opis uposażenia parafii $\mathrm{z}$ wyliczeniem pobieranych dziesięcin. Ziemia jest wydzierżawiona niejakiemu szlachcicowi Gabrielowi Czurapskiemu, za co pobierano czynsz 938 florenów. Z tego sam dzierżawca dawał na remont kościoła 165 florenów, k. 274v-275.

Inwentarz paramentów liturgicznych, srebrnych i z innego metalu naczyń, ornatów, bielizny, ksiagg i innego sprzętu, k. 275-276.

Inwentarz gospodarski żywy i martwy oraz opis zabudowań plebańskich, domu organisty i zakrystiana z podaniem ich dochodów, k. 276-276v.

Protokół podpisany przez wizytatora Schulza i notariusza Klińskiego w Nowem, dnia 1 II 1781 r., k. 276v-277.

Dekret reformacyjny dla kościoła w Nowem, wystawiony w tym mieście dnia 1 II 1781 r., k. 277-277v.

K o m ó r s k. Wykaz tabelaryczny parafii Komórsk. Obejmowała ona wsie: Komórsk, gdzie było 563 katolików, spowiadających się 463 oraz 30 akatolików; Komórsk Mały odpowiednio 50, 44, 11; Pastwisko 57, 50, 10; Warlub 162, 137, 6; Piaski 8, 6, 191; Rolewo 127, 99, -; Rolewko 13, 8, -; Rozgarty 12, 8, -; Kurzejowo 25, 20, -. Ogólnie zatem parafia liczyła 1017 katolików, z czego spowiadało się 835, a na Terenia parafii zamieszkiwało 248 akatolików, k. 278.

Wizytacja kościoła parafialnego Komórsk, w języku niemieckim Komorz. Świątynia pod wezwaniem św. Bartłomieja, zaś patronem drugorzędnym był św. Józef, Oblubieniec Najświętszej Marii Panny. Prawo patronatu należało do biskupa kujawskiego. Opis położenia parafii. Erygowana została przez biskupa włocławskiego Wisława, i przezeń konsekrowana, jak to widać było z dokumentu z 1295r. wydanego we Włocławku. Po spaleniu się pierwotnego kościoła, obecnie stojący, drewniany, w 1684 r. został odbudowany przez biskupa Bonawenture z Niedzielska Madalińskiego, przy współudziale kapituły włocławskiej, parafian oraz Teofila z Krowiczyn Dorpowskiego, podówczas właściciela dóbr Rulewo ${ }^{82}$ i Buzna, a także szeregu innych dobrodziejów, tu wyliczonych. Wprawdzie świątynia jest drewniana, ale wieża z solidnego muru. Kościół konsekrowany przez biskupa Madalińskiego. Wymieniono też tu wsie parafialne, tak, jak w wyżej po-

\footnotetext{
${ }^{82}$ Nazwę tej wsi pisano różnie.
} 
danej tabeli. Opis stanu świątyni, wymagającej już naprawy. Cmentarz ogrodzony. Zakrystia posiada wszystkie potrzebne paramenty i sprzęty. Były relikwie oraz przywileje odpustowe. Bractwa trzy, a mianowicie Różańcowe, św. Jana Nepomucena i Aniołów Stróżów. Bractwa te, a zwłaszcza Różańcowe, posiadały uposażenie oraz własne paramenty liturgiczne. Oratorium prywatne we wsi Rolewo, z indultem na odprawianie nabożeństw, jednak z zachowaniem prawa parafii. Kapelanem był zakonnik franciszkanin reformat z Nowego. Innowiercy mieszkający na terenie parafii nie mieli swojej kaplicy, jedynie cmentarz w polu niedaleko wsi Pastwisko. Żydów nie było. Szkoły nie było, a jedynie zimą uczył organista. Przytułek, zbudowany przez parafian, gdzie w połowie mieszkali ubodzy, a w drugiej organista, k. 279-281v.

Sposób sprawowania sakramentów - powiedziano jedynie o sakramencie chrztu, k. 281v.

Proboszcz Michał Pawłowski, kanonik kruszwicki, lat 39, z Pomorza, a mianowicie urodzony we wsi rodowej Rólewko. W parafii stale rezyduje. Obowiązki duszpasterskie spełnia. Opis nabożeństw. Wikariusz Mateusz Krajnicki, lat 39. W parafii kaplica we wsi Rolewo z kapelanem zakonnikiem. Był organista, ale nie podano nazwiska. Witrykusi pochodzili z Komorska i byli to: Jakub Gosieniewski, Antoni Laskowski i Szymon Karpus. Parafianie mieli swoje zwyczaje, ale o publicznych grzesznikach nic nie powiedziano, k. 281v-282v.

Opis uposażenia parafii z wyliczeniem dziesięciny, wykazem dochodów i rozchodów. Podano dochód organisty oraz spis inwentarza plebańskiego, żywego i martwego, bardzo dokładnie sporządzony, k. 282v-284.

Inwentarz paramentów liturgicznych kościoła w Komorsku, bardzo dokładny i bogaty, k. 284-286.

Opis zabudowań plebańskich, wikaryjki i innych gospodarczych, k. 286-286v.

Opis przytułku - szpitale, wystawionego przez parafian, gdzie mieszkało 7 ubogich, k. 286v.

Protokół powizytacyjny wystawiony w Komorsku dnia 8 II 1781 r., podpisany przez wizytatora i notariusza, k. 286v-287.

Dekret reformacyjny dla kościoła w Komorski, wystawiony w tej wsi w dniu 8 II 1781 r., k. $287-287 \mathrm{v}$.

Wizytacja kościoła parafialnego w Komorsku, według położenia i stanu, przeprowadzona w miesiącu lutym $1781 \mathrm{r}$., - jest to bardzo dokładny opis parafii, nieraz dokładniejszy, aniżeli sam powyższy protokół, podpisany przez proboszcza komorskiego i kanonika kruszwickiego Michała Pawłowskiego, k. 288-312.

L u b i e ń, dekanat nowski, k. 313. Wykaz tabelaryczny parafii Lubień. Do parafii należały wsie: Lubień Wielki, liczący 66 katolików i 50 spowiadających się; Lubień mały 7, 5; Zajączkowo Wielkie 20, 19; Zajączkowo Małe, 18, 18; Montawy 9, 9; Tragasz 49, 37. Tak więc ogólnie parafia liczyła 169 katolików, $\mathrm{z}$ czego spowiadających się 138. Akatolików, ani Żydów w parafii, według tego wykazu, nie było, k. 313v-314. 
Wykaz tabelaryczny parafii Bzowo. Należały tu wsie: Bzowo liczące 409 katolików, w czym spowiadało się 306; Osiek 7, 7; Kompania 4, 4; Krusze 54, 32; Bzowo 3, 3; Fletowo 5, 5; Grupa Wysoka 35, 27; Grupa Niska 2, 5 oraz wieś Piła niezamieszkana. Zatem parafia liczyła katolików519 i spowiadających się 386. Akatolików, ani Żydów na terenie parafii nie było, k. 315.

Wizytacja kościoła parafialnego w Lubieniu. Świątynia w Lubieniu Wielkim pod wezwaniem św. Jakuba Większego, prawa patronatu królewskiego. Opis położenia parafii. Kościół murowany, nie konsekrowany, a jedynie poświęcony. Luteran mieszkało około 30, zaś menonitów około 1000 w Lubieniu i Bzowie. Żydów nie było. Świątynia wprawdzie mutowana, ale niezbyt ładnie i niska, ale z sufitem murowanym. Kryty dachówką. Grobowiec, ale zamknięcie do niego zniszczone. Ogrodzenie, tak jak i cała świątynia wymagają naprawy, k. 316.

W zakrystii wprawdzie znajdują się potrzebne paramenta, ale niedbale ułożone i niezbyt czyste. W świątyni trzy ołtarze. Relikwii osobnych nie było. Przywileje odpustowe. Nie było osobnych kaplic, beneficjów, czy prebend. Innowiercy, a więc najprawdopodobniej luteranie, a także menonici w swoich domach sprawują swoje nabożeństwa i w ogrodach swoich się chowają, k. 316-316v.

Sposób sprawowania sakramentów, k. 316v.

Proboszcz Marcin Trojnarski, kanonik katedralny włocławski ${ }^{83}$ i prepozyt sądecki, posiadający dyspensę Stolicy Apostolskiej na kumulacje beneficjów. $\mathrm{W}$ pewne tygodnie przebywa $\mathrm{w}$ parafii, a w inne przy katedrze włocławskiej. Duszpasterstwo i kazania, albo osobiście sprawuje, albo przez wikariusza. Opis nabożeństw. Parafianie, ponieważ żyją sąsiedztwie luteran i menonitów, często z nimi zawierają małżeństwa wobec ich ministrów, co na poziom moralny nie wpływa dobrze. Nie podano tu nazwiska wikariusza, k. 316v-317.

Opis stanu ekonomicznego parafii. Wykaz świadczeń dziesięcinnych z poszczególnych wsi na rzecz proboszcza. Wykaz dochodów i rozchodów, k. 317.

Spis paramentów liturgicznych, k. $317 \mathrm{v}$.

Uzupełnienie do opisu stanu uposażenia parafii, k. 318.

Protokół powizytacyjny podpisany przez wizytatora Schultza i notariusza Klińskiego, w Lubieniu, dnia 3 II 1781 r.,. k. 318.

Dekret reformacyjny dla parafii Lubień i kościoła filialnego Bzowo, wystawiony w Lubieniu, dnia 3 II 1781 r., k. 318v-319.

Odpowiedzi na 328 pytań stawianych podczas wizytacji generalnej, $319^{84}$.

Wykaz tabelaryczny parafii Bzowo, zgadzający się z tym, który zamieszczony został na karcie 315. Dodano jedynie uwagę, że nie wiadomo o liczbie akatolików. Żydów nie było, k. 320v-321.

Wizytacja kościoła w B z o w i e, afiliowanego do parafii L u b i eń. Świątynia pod wezwaniem św. Małgorzaty, dawniej filialny parafii Komórsk, a obecnie Lubień. O dacie powstanie pierwszego kościoła na tym miejscu, powiedzieć trudno. Jeżeli za czasów biskupa Rozdrażewskiego była to świątynia znacznie zniszczona, to zapewne ją odbudowano z drewna. Gdy się chyliła ku upadkowi, poprzedni

\footnotetext{
${ }^{83}$ Biogram tego kanonika włocławskiego zob. Chodyński, Katalog, k. 962-6; 967-967a-968.

${ }^{84}$ Jest to jedynie tytuł. Właściwe odpowiedzi rozpoczną się od karty 324.
} 
proboszcz, zwany Traba, rozpoczął budowę nowej świątyni, murowanej od fundamentów i zapewne tę budowę skończyłby, gdyby nie przeszkodziła śmierć. Budowy dokończył obecny Proboszcz, kanonik włocławski, Marcin Trojnarski, który, zostawiwszy dawną dzwonnicę, nową murowaną świątynię wystawił, ale nie została ona jeszcze konsekrowana. Opis położenia parafii. Dosyć dokładny opis nowego murowanego kościoła, ze sklepieniem murowanym, ale zakrystia jest w stanie złym, k. 322.

Inwentarz rzeczy kościelnych, czyli paramentów liturgicznych. Opis trzech ołtarzy. Był przywilej odpustowy. Bractwa żadnego nie było. Rolę przytułku spełniał domek, w którym żyła jedna staruszka, utrzymująca się z jałmużny. W tym kościele sprawowano sakramenty tak jak w parafialnym. Procesje z Najświętszym Sakramentem urządzano w uroczystość św. Małgorzaty, Znalezienia i Podwyższenia Świętego Krzyża, k. 322-322v.

Uposażenietegokościoła, dawniejz 4łanów, teraztylkoz trzech, któresąw dzierżawie. Inwentarz gospodarski. Plebania nowa, przez obecnego proboszcza wystawiona. Inne zabudowania gospodarskie dobre. Organista mieszka d domu plebańskim i z dochodów plebańskich był utrzymywany, k. 322v-323.

Wykaz tabelaryczny parafii Lubień, całkowicie zgodny z wykazem na kartach 313v-314, k. 323v.

Odpowiedzi dane na piśmie na pytania postawione podczas wizytacji generalnej w 1780 r. Są to bardzo szczegółowe odpowiedzi, Tu znajdujemy nazwisko Głowacki, wikariusza parafii. Odpowiedzi te zostały własnoręcznie podpisane dnia 7 XI 1780 r. przez Marcina Mikołaja Trojnarskiego, kanonika włocławskiego i prepozyta sądeckiego, proboszcza parafii Lubień i Bzowo, k. 324-336v.

P ł o c h o c i n, dekanat nowski, k. 337. Parafia ta obejmował wsie: Płochocin obejmujący 244 katolików, 102 spowiadających się i gdzie mieszkało 11 akatolików; Płochocinek odpowiednio 2, 2, 79; Krzywin 14, 11, 52; Błądziejewo 20, 18, 5; Nowa Wieś, 9, 9, -; Święta Góra 5, 5, 1; Lipianki 76, 56, -; Młyn Borowy 13, 13, 8; Hamer 10, 8, 6; Stara Huta 7, 5, 18; Nowa Huta 5, 4, -; zamczyska gdzie mieszkało jedynie 4 akatolików; Bękowo 93, 77, 7; Młyn Bękowski 16, 14, 13. Ogółem więc było katolików 413, spowiadających się 344 oraz 204 akatolików. Żydów nie było, k. 328.

Wizytacja kościoła parafialnego płochocińskiego. Świątynia pod wezwaniem św. Wawrzyńca i św. Katarzyny, dziewicy i Męczennicy, prawa patronatu dziedziców dóbr Płochocin, aktualnie Antoniego Jasińskiego, sędziego ziemskiego tczewskiego i jego matki Marianny z Rembowskich Jasińskiej. Opis położenia parafii. Zbudowana została w 1701 r. kosztem Franciszka Jasińskiego, sędziego ziemskiego puckiego i Aleksandra Czapskiego, podkomorzego malborskiego. Wewnątrz drewniana, z zewnątrz z pruskiego muru, k. 339.

Kościół ten, zbudowany jak posiedziano wyżej, znajduje się w dobrym stanie. Sufit drewniany, niepotrzebujący naprawy. Dach kryty dachówką. W prezbiterium grobowiec fundatora. Dzwonnica z pruskiego muru. Cmentarz dobrze oparkaniony. Kostnicy brak, k. 339-339v. 
Spis paramentów liturgicznych i innych sprzętów kościelnych. Cztery ołtarze, dobrze urządzone i utrzymane, z obrazami, wszystko opisane. Relikwie św. Feliksa. Przywileje odpustowe. Prebend, ani beneficjów osobnych nie było. Bractwo Różańcowe zaprowadzone w 1727 r., za zezwoleniem władzy kościelnej, ordynariusza i papieża. Zachowuje swoje przepisy, utrzymuje się z jałmużny. Prowadzi księgi członków oraz rachunkowe dochodów i rozchodów. Kaplic publicznych nie było. Kaplica prywatna we wsi Bękowo, wystawiona na nowo, w miejsce starej, ale się w niej jeszcze nie odprawiało. Akatolicy zbierają się na swoje nabożeństwa i jednym z domów w Płochocinku i Krzywinie. Niekiedy z konieczności dzieci chrzczą w kościele parafialnym. Szkoły nie było, ale organista uczył podstaw wiary i początków czytania. Przytułek, gdzie mieszkał też organista, w średnim stanie. Żyło tam czterech ubogich, utrzymujących się z jałmużny, k. 339v$-340 \mathrm{v}$.

Sposób sprawowania sakramentów, k. 340v-341,

Proboszcz Michał Józef Pączkowski, lat 53, pochodzący z Pomorza. Rezydował na miejscu w parafii i osobiście prowadził duszpasterstwo. Opis nabożeństw. Wikariusza nie było. Organista Szymon Dubielski. Witrykusi Wojciech Faletowski i Szymon Kuberski. Zakonników żadnych nie było. Wprawdzie zdarzali się parafianie niezbyt gorliwi, ale publicznych grzeszników nie było, k. 341-341v.

Stan ekonomiczny parafii. Parafia uposażona w ziemię oraz zapis z $1728 \mathrm{r}$. uczyniony przez Franciszka Jasińskiego, sędziego ziemskiego puckiego 500 florenów zabezpieczony na dobrach Płochocin, a także 250 florenów z darowizny Doroty Wyderowna, zabezpieczone na dobrach niejakiego Franciszka Gardańskiego, mieszczanina z Nowego. Wykaz dochodów z pobieranych dziesięcin. Stan zabudowań plebańskich. W przytułku stojącym naprzeciw kościoła, w połowie mieszkał organista, a w połowę zajmowali ubodzy. Opis dochodów organisty. Inwentarz gospodarki zawierający także wykaz zwierząt, sprzętów, a nawet kilka książek, k. 341v-342v.

Protokół powizytacyjny, podpisany w Płochocinie, dnia 5 II przez wizytatora i notariusza, k. 342v-343.

Dekret reformacyjny także wystawiony w Płochocinie 5 II 1781 r., k. 343.

Wykaz tabelaryczny parafii Płochocin, całkowicie zgodny z tym na karcie 338 , k. 343v-344.

Dokładny opis parafii sporządzony i podpisany przez proboszcza Płochocińskiego, Michała Józefa Piączkowskiego ${ }^{85}$, k. 345-350v.

J a n i a [Kościelna Jania], dekanat nowski, k. 351. Wykaz tabelaryczny parafii Jania. Parafia obejmowała wsie: Kościelna Jania, gdzie było katolików 153, z czego spowiadało się 107, akatolików natomiast nie było; Stara Jania licząca 172, 123, 3 akatolików; Kownatka 18, 14, 30; Bobrowiec 20, 15, 8; Wielkie Komorze 7, 4, 7; Małe Komorze 13, 8, -; Długoleszcz 16, 7, -; Grabowiec 16, 11, -; Nicponi, 9, 7, -; Pastwisko, czyli Wołownik gdzie było 6 akatolików, Leśna Janaia 173, 116, 5; Młyn Słuchacz 4, 4, -; Jaszczer 12, 6, -; Oskarpiec 16, 12. -. Ostatecz-

${ }^{85}$ To nazwisko tak tu napisano. 
nie więc w parafii ogółem katolików było 620, spowiadających się 434 oraz zamieszkiwało tu 59 akatolików, k. 351v-352.

Wizytacja kościoła parafialnego Jania. W języku polskim używano już nazwy Kościelna Jania. Świątynia pod wezwaniem Swiętej Trójcy. Dawna świątynia była drewniana. Obecna, murowana kosztem Piotra Kostka, dziedzica wsi Jania, Konsekrowana przez biskupa włocławskiego Macieja Łubieńskiego w $1681 \mathrm{r}^{86}$ Wieża pochodziła jeszcze z czasów krzyżackich. Prawo patronatu należało do córek Tomasza i Marianny Czapskich, współwłaścicielek dóbr Jania, Urszuli Małachowskiej i Konstancji Radziwiłł. Opis położenia parafii. Zapisano tu, iż w parafii było 620 katolików, spowiadających się 434, 59 akatolików, natomiast nie było Żydów, k. 353-353v.

Świątynia murowana, z dwiema kaplicami po stronie północnej św. Mikołaja i południowej św. Józefa. Murowana zakrystia za wielkim ołtarzem. Wszystko kryte dachówką. Zakrystia wyposażona w potrzebne sprzęty kościelne. Opis trzech ołtarzy, jednej w świątyni i po jednej w kaplicach. Relikwii nie było. Przywilej odpustowy z racji bractwa Świętej Trójcy oraz Drogi Krzyżowej, udzielony przez Stolicę Apostolską w 1740 r., Za wiedza Konsystorza Generalnego Gdańskiego. Prebend, ani osobnych beneficjów nie było, k. 353v-354.

Bractwo Świętej Trójcy zaprowadzone za wiedzą Stolicy Apostolskiej oraz Konsystorza Gdańskiego w 1748 r. Ma księgę swoich statutów, a także dochodów i wydatków. Nie było żadnego zapisu fundacyjnego dla tego bractwa, jak i utrzymania Drogi Krzyżowej. Spis inwentarza rzeczy należących do bractwa, k. 354$-354 \mathrm{v}$.

Nie było żadnej kaplicy prywatnej, ani publicznej. Szkoły nie było, ale w organistówce, zbudowanej kosztem parafian uczył organista zasad wiary i czytania, ale aktualnie uczniów nie było. Przytułek znajdował się obok kościoła, gdzie znajdowało się 6 ubogich. Jest też podana wiadomość o zapisie niejakiej Katarzyny Czerwińskiej 400 florenów na magistracie w Nowem, z czego dochód 6 od 100 był przeznaczony na różne cele, w tym także 6 florenów dla ubogich przytułku w Janii, k. 354v.

Sposób sprawowania sakramentów, k.354v-355.

Zarządcą parafii był Jan Józef Halba, liczący lat 47, pochodzący z Pomorza, przy kościele parafialnym rezydujący i innego beneficjum nieposiadający. Duszpasterstwo sam sprawuje. Księgi metryk prowadził. Przypomniano, jakie były zarządzenia z poprzedniej, z 1766 roku, wizytacji i czy je wykonano. Spis kilku książek. Zakonników w parafii nie było. Krótka charakterystyka parafian, k. 355$355 \mathrm{v}$.

Stan ekonomiczny parafii. Składała się na to ziemia oraz dziesięciny, tu wyliczone. Wykaz dochodów i rozchodów. Dwaj Witrykusi, z nazwiska niewymienieni, pochodzili ze wsi Kościelna Jania, k. 355v-356v.

${ }^{86}$ Jest tu oczywisty błąd. Biskup Maciej Lubieński był we Włocławku w latach 1631-1641, a potem został arcybiskupem gnieźnieńskim. 
Dokładny spis paramentów liturgicznych i innego sprzętu kościelnego oraz inwentarza gospodarskiego, tak żywego, jak i martwego z podaniem tego, co uległo straceniu za poprzedniego proboszcza, k. 356v-357v.

Opis stanu zabudowań plebańskich, a wiec samej plebanii i pozostałych zabudowań gospodarczych. Opis domu organisty i jego uposażenie, ale nazwiska organisty nie podano, k. 358 .

Szpital o trzech pomieszczeniach, w jednym mieszkało sześciu ubogich, w drugim uboga szlachcianka, a w trzecim kopacz.. Do tego przytułku należał ogród oraz wyżej wspomniany dochód 6 florenów, k. 358-358v.

Dodatkowy spis jedenastu książek, k. 358v.

Protokół powizytacyjny spisany 10 II 1781 r, w Janii i podpisany przez wizytatora i notariusza, k. $358 \mathrm{v}$.

Dekret reformacyjny wystawiony w Janii, dnia 10 II 1781 r., k. 359.

Wykaz tabelaryczny parafii Jania, całkowicie zgodny z tym, który na kartachb351-352 był już zapisany, k. 360-361.

\section{G 72}

\section{A. OPIS KSIĘGI}

[1. Sygn. akt.] G 72.

[2. Tytuł oryg.] Visitatio Generalis Ecclesiarum Parochialium in Decanatu Gedanensi et Pucensi consistentium, ex mandato Illustrissimi et Reverendissimi Domini Iosephi Rybiński Episcopi Wladislaviensis et Pomeraniae, per Perillustrem Admodum Reverendum Joannem Bastkowski, Canonicum Catchedralem Livoniae, Decanum Foraneum et Praepositum Starogardensem, generalem deputatum visitatorem ab anno 1782 inchoata et eodem anno expedita.

[3. Daty krańc.] 1782

[4. Opis zewn.] Łac.-pol. $(33,5 \times 21,0 \mathrm{~cm}$.) Kart paginowanych 378. Okładka w półskórek ze zniszczonym grzbietem. Pismo wyraźne i czytelne, zdaje, że jednej ręki. Strony puste: k. 2v, 6v, 8, 9v; 10v, 12, 22v, 43v, 51v, 52v, 67v, 70v, 80v, $89 \mathrm{v}, 103 \mathrm{v}, 114 \mathrm{v}, 115 \mathrm{v}, 119^{\mathrm{a}} \mathrm{v}, 131 \mathrm{v}, 133 \mathrm{v}, 143 \mathrm{v}, 153 \mathrm{v}, 155 \mathrm{v}, 172 \mathrm{v}, 183 \mathrm{v}, 192 \mathrm{v}$, $195 \mathrm{v}, 206 \mathrm{v}, 216 \mathrm{v}, 223 \mathrm{v}, 224 \mathrm{v}, 231 \mathrm{v}, 232 \mathrm{v}, 238 \mathrm{v}, 240 \mathrm{v}, 247 \mathrm{v}, 257 \mathrm{v}, 259 \mathrm{v}, 269 \mathrm{v}$, $277 \mathrm{v}, 286 \mathrm{v}, 297 \mathrm{v}, 305 \mathrm{v}, 307 \mathrm{v}, 313 \mathrm{v}, 323 \mathrm{v}, 331^{\mathrm{a}} \mathrm{v}, 332 \mathrm{v}, 343 \mathrm{v}, 349 \mathrm{v}, 350 \mathrm{v}$.

Niektóre karty, przy oprawie, zostały obcięte wraz z częścią tekstu. Jest kilka wypadków, że przy foliacji opuszczono niektóre karty, lub spisano je podwójnie.

[5. Uwagi] Jak widać to $z$ tytułu, wizytatorem $\mathrm{z}$ ramienia biskupa był prepozyt i dziekan starogardzki Jan Bastkowski, zaś sekretarzem Jan Bąkowski.

W księdze pod określeniem kościół, rozumiano parafię, stąd pisano wizytacja kościoła w miejscowości N, zamiast wizytacja parafii w miejscowości $\mathrm{N}$.

Parafia zarządzali proboszczowie, ale często byli to jedynie zarządcy, nazywani ,curatus”.

Księga ta kontynuuje niezwykle dokładne protokoły sporządzane z polecenia biskupa Józefa Ignacego Rybińskiego, który opracował dokładny formularz wizy- 
tacyjny. W większości przypadków proboszczowie sporządzali na piśmie odpowiedzi na 327 szczegółowych pytań, gdzie właściwie zawarte są dokładne wiadomości o parafii. Nawet zamieszczali identyczne wykazy tabelaryczne do tych zamieszczonych we właściwym protokóle wizytacyjnym. Te odpowiedzi są najczęściej bardziej dokładne, aniżeli same protokóły.

Dokładnie omawiano sprawowanie sakramentów, co umożliwia poznanie duszpasterstwa sakramentalnego,

Przy wiadomości o proboszczu zamieszczano dosyć dokładne dane o jego urodzeniu, wykształceniu, a także o sprawowanych w parafii nabożeństwach, prowadzeniu ksiag metrycznych itp. Zatem jest tu mnóstwo danych tak personalnych, jak i do sprawowanego duszpasterstwa. Ale szczegółów tych nie notowano w niniejszym repertorium..

Do statystyk niezwykle przydatne są tabele. Niektóre tabele bardzo uszkodzone i wymagałyby podklejenia. $W$ tabelach tych podawano także wiadomości o właścicielach poszczególnych wsi, ale w repertorium zrezygnowano z notowania tego.

Dosyć dokładne są opisy świątyń, a także zabudowań gospodarczych. Często podawano ilość wysianego ziarna w gospodarstwie proboszczowskim. Niekiedy notowano nazwiska dzierżawców, gdy ziemia beneficjalna nie była uprawiana przez samego zarządcę parafii. Wszystko to może być przydatne tak do badań tak nad architekturą ówczesnych gospodarstw wiejskich, jak i nad gospodarstwem plebańskim. Nazwy miejscowości podawano według brzmienia stosowanego w księdze.

\section{B. ZAWARTOŚĆ KSIĘGI}

Na wewnętrznej okładce napis: Rybiński (XII) per Bastkowski 1782 oraz notatki niemieckie.

Pierwsza karta nie liczbowana z napisem niemieckim oraz pieczęcią Archiwum Diecezji Pelplińskiej - Pelplin.

Tytuł pełny jak wyżej, k. 1 .

\section{Dekanat pucki}

Wykaz tabelaryczny parafii dekanatu puckiego, zawierający główne dane następujących parafii: Puck, Swarzewo, Mechowa, Żarnowiec, Tyłowo, Wejherowo, Rumia i Oksywie. Podano najważniejsze wiadomości o parafiach, ich oddaleniu od parafii, gdzie rezydował dziekan oraz o proboszczach, k. 1v-2.

Wizytacja dekanatu puckiego diecezji pomorskiej. Podstawowe wiadomości o dekanacie i postanowienia, co do przyszłej wizytacji, której odbycie postanowił biskup Józef Ignacy Rybiński. Dziekanem dekanatu puckiego był Jan Józef Grę$\mathrm{ca}^{87}$, k. 3-4.

${ }^{87}$ Nie zna tego kanonika Fiutak pisząc swój Katalog pratatów i kanoników kruszwickich [rkps w Archiwum Diecezjalnym we Włocławku]. 
Odpowiedzi, jakie powinny być dane przez dziekana na stawiane pytania podczas wizytacji generalnej dekanatu puckiego, dnia 18 III $1781 \mathrm{r}$. Sa tu podane najważniejsze dane dotyczące dekanatu. Dziekanem był Jan Gręca, kanonik kruszwicki, prepozyt pucki. Podano imiona proboszczów. Pytań było ogółem 35, k. 5-6.

Dekret reformacyjny odnoszący się do dziekana puckiego, wystawiony 1 VIII 1782 r., przez Jana Bastkowskiego, i przez niego osobiście podpisany i pieczęcią w opłatku uwierzytelniony. Sekretarzem był Jan Bakkowski, k. 7-7v,

Wykaz tabelaryczny dekanatu puckiego, podobny do poprzedniego. Podano tu wiadomościokościele prepozyturalnymw Pucku, kościołach parafialnych w Swarzewie, Mechowej, gdzie duszpasterstwo prowadził zakonnik z Oliwy, Żarnowcu, gdzie był klasztor benedyktynek, Tyłowie, Wejherowie, Rumii, gdzie proboszczem był zakonnik z Oliwy oraz o parafii w Oksywiu, k. 8v-9.

P u c k. Wizytacja parafii w Pucku. Opis położenia parafii. Stan świątyni parafialnej, murowanej, wyposażenia, opis ołtarzy, relikwii i przywilejów odpustowych. Bractwo Niepokalanego Poczęcia Najświętszej Marii Panny. Kaplicy publicznej w parafii nie było. Dysydenci poosiadali swój zbór i cmentarz. Żydzi mieli swoją prywatną szkolę. Parafia prowadziła szkolę w Pucku i w dwóch wsiach, gdzie uczył niejaki Jan Zienkiert. Przytułek, wystawiony z pruskiego muru, dawał schronienie siedmiu starcom. Posiadał niewielkie uposażenie. Opiekował się nim proboszcz. Prebenda przy kaplicy Chrystusa Ukrzyżowanego i druga przy kaplicy Zwiastowania Najświętszej Marii Panny. Wykaz aniwersarzy w kościele parafialnym w Pucku, k. 11-14v.

Wykaz tabelaryczny parafii w Pucku. Puck miasto (civitas) liczyło ogółem 505 katolików, z czego spowiadających się było 387 osób, akatolików 219, ponadto mieszkało tu 45 Żydów; Wieś Połczyno odpowiednio 201, 144, 4, -; Brzezino 140, 100, 8, -; Polchowo 97, 74, 1, - ; Smolno 191, 140, -, -; Brudzewo 64, 48, 3, -; .Celbowo 58, 33, 20, -; Rucewo i Kruszwica 81, 61, -, -; Żelistrzewo 142, 102, -, -; Błędzikowo 102, 70, -, -; Wielkie Stabułowo 88, 65, -, -; Małe Stabułowo 68, 65, -, -; Osłonino 248, 193, 1, -; Rekka 28,17, 1, -. Ogółem więc wiernych było 2013, spowiadających się 1481, akatolików 281 i 45 Żydów $^{88}$, k. 12.

Sposób sprawowania sakramentów, k. 14v-15v.

Proboszcz, z tytułem prepozyta, był Jan Józef Gręca ${ }^{89}$, dziekan pucki i kanonik kruszwicki. Wikariusz Bernard Getzki. Organista Michał Zienkiert, kantor i zakrystian Józef Borysz, dzwonnik Marcin Karznia. Parafianie to ludzie prości, ale publicznych gorszycieli nie było, k. 15v-17.

Stan uposażenia parafii. Wykaz pobieranych dziesięcin, k. 17-18v.

Opis świątyni w Pucku, murowanej, pod dachówką, i jej wyposażenia w paramenty liturgiczne, k. 18v-20.

${ }^{88}$ Sporządzając skrót wykazów tabelarycznych podawano ilość osób w następującej kolejności: wierni ogółem, wierni spowiadający się na Wielkanoc, akatolicy, Zydzi,

${ }^{89}$ Nie zna tego kanonika Fiutak w swoim Katalogu prałatów i kanoników kruszwickich. 
Stan zabudowań plebańskich, wystawionych w pruski mur, spis inwentarza oraz stan zabudowania dla organisty. Szpital o czterech pomieszczeniach, na gruncie miejskim, od dawna darowanym przez miasto, k. 20.

Protokół podpisany przez wizytatora Jan Bastkowskiego i sekretarza Jana Bąkowskiego, wystawiony w Pucku, dnia 18 III 1781 r, k. 20-20v.

Dekret reformacyjny dla kościoła parafialnego w Pucku, podpisany przez wizytatora Jana Bastkowkiego i sekretarza Jana Bąkowskiego, k. 21-21v.

Odpowiedzi na pytania stawiane $\mathrm{z}$ racji wizytacji parafii w Pucku, dnia 18 III 1781 r. Ogółem bardzo szczegółowych pytań było $328^{90}$, k. 22-32v.

$\mathrm{S} w$ a r z e w o ${ }^{91}$. Dekret reformacyjny dla kościoła parafialnego w Swarzewie, wystawiony 24 VII 1782 r. podpisany przez wizytatora Jana Bastkowskiego i sekretarza Jana Bąkowskiego, k. 33-33v.

Odpowiedzi na pytania stawione przy wizytacji kościoła parafialnego w Swarzewie w 1781 r. Wizytacja odbyła się 20 III 1781 r. Do parafii Swarzewo należały jako kościoły filialne Strzelno i Łebcz, k. 34-41v.

S t r z e $1 \mathrm{n}$ o. Stan drewnianego kościoła filialnego w Strzelnie, pod wezwaniem św. Marii Magdaleny. Znajdowały się niezbędne do liturgii paramenta. $\mathrm{Na}$ uposażenie były dwa łany ziemi z nadania króla Zygmunta Augusta z 1552 r., co zostało później potwierdzone w 1633 r. przez króla Władysława IV, k. 42.

Stan kościoła we wsi Ł e b c z, zniszczonego przez wichurę w 1747 r. Pozostały fundamenty i fragmenty ścian. Wyposażenie przeniesiono do Swarzewa. Pozostało uposażenie w cztery łany, jeszcze z czasów krzyżackich. Wizytator postulował potrzebę odbudowania tej świątyni, k. 42-42v ${ }^{92}$.

M e c h o w o. Wizytacja kościoła parafialnego w Mechowie w roku 1781. Kościół pod wezwaniem św. Mikołaja. Prawo patronatu należało do zakonników z Oliwy. Opis stanu świątyni i jej wyposażenia. Bractwa żadnego nie było, ani kaplic publicznych czy prywatnych. Przytułku nie było. Dzieci uczył organista Jakub Hyntzka, k. 43-46v.

Wykaz tabelaryczny parafii Mechowo, k. 45. Wsie: Mechowo liczące 152 katolików, z czego spowiadało się 126 oraz była jedna osoba akatolicka, Darzlubie z kolonią Zdrada 174, 134, 9; Łusniewo z kolonią Sikorzyn 86, 67, 2; Domanowo, Domatówko i Czechów 104, 83, -; Piaśnica Wielka, Piaśnica Mała, Muza i Bieszek 67, 56, 1; Starzyn z kolonia Głuchowo 176, 146, 6; Starzyński Zamek 57, 46, 19; Werblin 165, 140, -; Polchowo i Rzemiętówko 12, 10, 36; Parzkowo, Dąbrowa, Młynik 70, 59, 1; Kłania 87, 76, 7; Radoszewo 58, 47, 3. Ogółem więc katolików było 1208, spowiadających się 993, akatolików 85, ale nie było Żydów, k. 45 .

${ }^{90}$ Wprawdzie nie podano, kto na te pytania odpowiadał, ale najprawdopodobniej sam proboszcz Jan Gręca, ponieważ on w parafii rezydował. tatora.

${ }^{91}$ Nie ma protokółu powizytacyjnego. Zastąpi go dokładny spis odpowiedzi na pytania wizy-

${ }^{92}$ Opis świątyni w Strzelnie i tego co pozostało w Łepczu sporządził proboszcz ze Swarzewa. 
Sposób sprawowania sakramentów, k. 46v-47v.

Proboszczem był zakonnik, cysters z Oliwy, Mikołaj Lerchenfeldz. Wikariuszem był także zakonnik, Ignacy Śliwiński. Organista Jakub Hyntzka. Obowiązki witrykusów sprawowali: Maciej Bolda, będący sołtysem, Jerzy Rejszmanel i Mikołaj Brakt. Krótka charakterystyka parafian, k. 47v-49.

Stan ekonomiczny parafii, wykaz dochodów i wydatków. Opis świątyni murowanej w pruski mur i jej stan., k. 49-50.

Spis paramentów liturgicznych oraz inwentarz gospodarczy, żywy i martwy. Opis stanu zabudowań, k. 50-51.

Protokół podpisany w Mechowie dnia 23 III 1781 r. przez wizytatora Jana Bastkowskiego i sekretarza Jana Bąkowskiego, k. 51.

S t a r z y n o. Wizytacja kościoła parafialnego w Starzynie w roku 1781. Świątynia pod wezwaniem św. Michała Archanioła, murowana, wzniesiona w $1649 \mathrm{r}$. przez opata oliwskiego Aleksandra Kęsowskiego. Prawo patronatu należało do opata oliwskiego, aktualnie Jacka Rybińskiego. Opis stanu świątyni, ołtarzy i obrazów. Osobnych prebend nie było. Bractwo św. Józefa założone w 1763 r., z niewielkim uposażeniem z zapisu Franciszka Kłanickiego. Akatolicy w dobrach Krockau mieli swoje publiczne oratorium, a chowali się nas wydzielonej części cmentarza parafialnego. Przytułku nie było. Szkoła parafialna, opłacana przez rząd, gdzie uczył nauczyciel katolik, k. 53-54.

Sposób sprawowania sakramentów, k. 54v.

Proboszcz i wikariusz ci sami co w Mechowie. Na miejscu nie rezydowali, ale podprawiało się nabożeństwo w co drugą niedzielę i w drugi dzień świat. Stan ekonomiczny parafii z wykazem inwentarza kościelnego to znaczy paramentów liturgicznych. Inwentarza gospodarczego nie było, k. $54 \mathrm{v}-56$.

Protokół podpisany w Mechowie dnia 23 III 1781 r. przez wizytatora i sekretarza, k. 56-56v.

Dekret reformacyjny dla kościołów parafialnych w Mechowie i Starzynie, wystawiony dnia 5 VIII 1782 r., wystawiony przez wizytatora, k. 58-58v.

Odpowiedzi na pytania, postawione podczas wizytacji kościoła parafialnego w Starzynie w 1781 r., sporządzony zapewne przez aktualnego proboszcza, k. 59$-67$.

Opis stanu kościoła w Starzynie, k. 68-69v ${ }^{93}$.

T y ł o w o. Wizytacja kościoła parafialnego w Tyłowie z roku 1781. Świątynia pod wezwaniem Matki Bożej. Prawo patronatu należało do Józefa Przebendowskiego i jego sukcesorów. Opis jej stanu i wyposażenia w sprzęty kościelne i paramenty liturgiczne. Opis znajdujących się w nim ołtarzy i obrazów. Był zapis lokowany na dobrach Tyłowo, uczyniony przez Helenę Morszczynową na dwie msze w roku dla proboszcza. Bractwa nie było. Akatolicy chowali się na wydzie-

${ }^{93}$ Opisy kościoła w Starzynie uczynione tą samą ręka, co odpowiedzi na pytania dotyczące parafii Mechowo. 
lonej części cmentarza parafialnego. Przytułku nie było. W szkole uczył organista Paweł Munda, k. 70.73v.

Wykaz tabelaryczny parafii w Tyłowie. Wsie: Tyłowo liczące 90 katolików, spowiadających się 60 i 1 akatolika, Lubocino 40, 36, 5. Ogółem zatem parafia liczyła 130 wiernych, z czego spowiadało się 96 oraz 6 innowierców. Żydów nie było, k. 72.

Sposób sprawowania sakramentów, k. 73v-75.

Po śmierci poprzedniego proboszcza Szaskowskiego, nastał Ignacy Złochowski. Organista Paweł Munda. Zakonników nie było. Krótka charakterystyka parafian, k. 75-76.

Stan ekonomiczny parafii i jej dochody. Opis kościoła wystawionego w Pruski mur. Spis paramentów liturgicznych. Zabudowania plebańskie, k. 76-78.

Protokół powizytacyjny podpisany w Tyłowie 23 III 1781 r., k. 78-78v.

Dekret reformacyjny dla parafii Tyłowo z dnia 20 VII 1782 r., wystawiony i podpisany przez wizytatora i sekretarza, k. $79-79 \mathrm{v}$.

Odpowiedzi na pytania postawione podczas wizytacji kościoła parafialnego w Tyłowie w roku 1781 sporządzone i spisane przez zarządcę Jakuba Złochowskiego, k. $80-88 \mathrm{v}$.

W e j h e r o w o i Gó r a. Wizytacja kościoła parafialnego w Wejherowie i filialnego w Górze w 1781 r. Nowe miasto Wejherowo (oppidum) miało świątynię pod wezwaniem Trójcy Świętej, Prawo patronatu, jak przypuszczał wizytator, należało do właścicieli dóbr, nieżyjącego już Józefa Przebendowskiego [i zapewne jego sukcressorów]. Świątynia murowana, wyposażona w potrzebne rzeczy. Opis ołtarzy i obrazów. Bractwo Szkaplerza, ale nie ma swoich statutów, chociaż erygowane powagą Stolicy Apostolskiej. Kaplice w liczbie 25 w lesie sąsiadującym z Wejherowem, czyli kaplice kalwaryjskie przy klasztorze franciszkanów reformatów. Szkoły parafialnej nie było, ale franciszkanie prowadzili szkołę, gdzie uczyło się 68 uczniów. Przytułek na sześć osób, mający swoje uposażenie, tu wyliczone, k. 89-95.

Wykaz tabelaryczny parafii Wejherowo, do której należało miasto Wejherowo liczące 568 katolików, spowiadających się 396, a akatolików 262; wieś Góra 55, 38, 33; Warzkowo 48, 25, 44; Kniewo 18, 12, 256; Nanice 52, 35, 15; Śmiechowo 123, 86, 18; Łętkowice 63, 42, 1; Rybno 58, 43, 50; Zelewo 62, 49, 58; Bolszewo 69, 41, 103; Orla 12, 8, 56. Ogółem, więc parafia liczyła 1120 katolików, z czego spowiadało się na Wielkanoc 775 osób, zaś akatolików mieszkało tu 896 osób, k. 91.

Sposób sprawowania sakramentów, k. 93-94.

Proboszcz z tytułem prepozyta Franciszek Antoni Greca, rezydujący na miejscu i sprawujący duszpasterstwo. Słudzy kościoła to organista Antoni Bruch i drugi Franciszek Borysz. W parafii klasztor franciszkanów reformatów, gdzie było 13 kapłanów, 4 braci, żyjących z samej jałmużny. Szanowali prawa parafii, co do nabożeństw. Krótka charakterystyka parafian, k. 94-55v.

Stan ekonomiczny parafii i dochody oraz rozchody gospodarki beneficjum proboszcza. Opis stanu świątyni. Wykaz paramentów liturgicznych, stan zabudowań proboszczowskich oraz spis inwentarza gospodarczego, k. $95 \mathrm{v}-97 \mathrm{v}$. 
G ó r a. Opis kościoła filialnego w Górze. Świątynia pod wezwaniem św. Macieja Apostoła. Prawo patronatu należało do dziedziców dóbr Wejherowo. Stan zewnętrzny świątyni i jego wyposażenie w potrzebne sprzęty kościelne. Opis ołtarzy i obrazów. Relikwii nie było. Akatolicy posiadali swoje oratorium w Bolszewie, Szkoły ani przytułku nie było, k. 98-99.

Sposób sprawowania sakramentów, k. 99-99v.

Proboszczem był prepozyt z Wejherowa, k.99v-100.

Opis uposażenia oraz stanu świątyni drewnianej i je4j wyposażenie. Wykaz inwentarza kościelnego oraz stan zabudowań plebańskich, k. 100-101.

Protokół podpisany w Wejherowie dnia 24 III 1781 r. przez wizytatora i sekretarza, k. 101.

Dekret reformacyjny dla kościoła w Wejherowie i Górze z dnia 9 VIII 1782 r., podpisany przez wizytatora i sekretarza, k. 102-102v.

Odpowiedzi na pytania postawione podczas wizytacji parafii Wejherowo, spisane dnia 24 III 1781 r., k. 103-114.

Wykaz tabelaryczny parafii Wejherowo. Miasto Wejherowo liczyło ogółem katolików 568, z czego spowiadających się na Wielkanoc było 396, akatolików 262, Żydów natomiast w parafii nie było; Góra odpowiednio55, 38, 23; Warzkowo 48, 25, 44; Kniewo 18, 12, 236; Nanice 52, 36, 15; Śmiechowo 123, 86, 18; Petkowice 63, 42, 9; Rybno 58, 45, 50; Bolszewo 69, 41, 103; Orla 12, 8, 56; Żelewo $62,49,38$. Ogółem w parafii było 1128 katolików, spowiadających się na Wielkanoc 777, zaś akatolików mieszkało 854, k. 105.

G ó r a. Wizytacja kościoła w Górze w 1781 r. Są to także odpowiedzi na pytania wizytacyjne, ale nie na wszystkie, k. 115-119v.

R u m i a i R e da. Wizytacja kościoła parafialnego w Rumii i filialnego w Redzie, w roku 1781, k. $119^{\text {a94 }}$.

Wykaz tabelaryczny parafii Rumia, k. 120. Wsie: Rumia licząca katolików 277, spowiadających się 173, akatolików 5; Kadzmierz 44, 33, -; Reda 148, 101, 120; Zagorze 99, 67, 14; Szmolta 42, 28, 14; Ciechocino 125, 77, 7; Rekowo 116, 81, 6; Pieleszewo 70, 47, 5; Wyspowo 23, 17, 2; Gniewowo 96, 59, 2; Łężyce 98, 66, 12; Zbychowo z Cegielnia 79, 56, -; Nowa Wieś i Pynek 53, 44, 2; Nowy Dwór 35, 17, -. Zatem ogółem katolików 1305, spowiadających się 876, akatolików 192. Żydów nie było, k. 120.

Wizytacja kościoła parafialnego w Rumii, noszącego wezwanie Świętego Krzyża. Prawo patronatu należało do zakonników cystersów. Opis stanu świątyni i jej wyposażenia, ołtarzy i obrazów. Bractwo Bożej Opatrzności. Akatolicy chowali się na wydzielonej części cmentarza parafialnego. Przytułku nie było, a ubodzy mieszkali po wsiach. Dzieci uczył, zwłaszcza w okresie zimy, organista Jakub Lasynius, k. 121-122v.

Sposób sprawowania sakramentów, k. 122v-123v.

${ }^{94}$ Tylko karta tytułowa protokołu. 
Proboszcz Norbert Łyśniewski, zakonnik cysterski z Oliwy. Innych kapłanów nie było. Organista Jakub zwany Lasunius. Krótka charakterystyka parafian, k. 124-125.

Stan ekonomiczny parafii z wyliczeniem pobieranej dziesięciny oraz wykaz dochodów i rozchodów. Opis świątyni, z murowanym prezbiterium i nawą oraz dzwonnica stawiana w pruski mur. Wykaz paramentów liturgicznych oraz opis zabudowań plebańskich. Spis inwentarza gospodarczego, k. 125v-127.

Opis kościoła filialnego w Redzie. Świątynia pod wezwaniem Wniebowzięcia Najświętszej Marii Panny, zbudowana z pruskiego muru w 1770 r., staraniem ówczesnego proboszcza Mikołaja Lerchenfeldt oraz z ofiar. Prawo patronatu należało do króla pruskiego. Stan aktualny świątyni, ołtarzy i obrazów. Bractwo Różańcowe. Kaplica we wsi Zagorze, zbudowana przez dziedziców Przebendowskich, bez uposażenie i nie dla sprawowania nabożeństw, ale dla złożenia tam obrazów i innych rzeczy kościoła w Sztolcemgergu, a także tego co potrzebne dla odprawiania Drogi Krzyżowej [zapewne do kalwarii Wejherowskie]. Opiekowali się tym zakonnicy reformaci. Akatolicy chowali się na cmentarzu parafialnym. Przytułku nie było. Dzieci uczył nauczyciel jedynie zimą, k. 127v-128v.

Sposób sprawowania sakramentów, k. 128v-129.

Proboszcz ten, co w Rumii, bo w Redzie był kościół filialny. Odprawiano tu nabożeństwa w drugą niedzielę [pewnie miesiąca] oraz w święto odpustowe. Organistą był Adam Kruża, k. 129-129v.

Stan ekonomiczny kościoła. Były cztery łany ziemi, które Proboszcz wydzierżawił. Opis dokładny świątyni murowanej wystawionej w 1770 r. w pruski mur. Spis paramentów liturgicznych. Inwentarza gospodarczego nie było. Budynki plebańskie zrujnowane i potrzebują nowego wystawienia, k. 129v-130v.

Protokół wystawiony w Rumii, dnia 17 III 1781 r. podpisany przez wizytatora i sekretarza, k. 130-131.

Dekret reformacyjny dla parafii Rumia i filii Reda z dnia 23 VII 1782 r., wystawiony przez wizytatora i przezeń oraz przez sekretarza podpisany, k. 132-132v.

Odpowiedzi na pytania postawione z racji wizytacji parafii Rumia w 1781 r., k. 133-140v.

Opis kościoła filialnego w Redzie (nie dokończony), k. 141-141v ${ }^{95}$.

O k s y w i e i Chy 1 o n i a. Wizytacja kościoła parafialnego w Oksywiu i filialnego w Chylonii, k. $142^{96}$.

Wizytacja kościoła w O k s y w i u, pod wezwaniem św. Michała Archanioła. Odbudowany jako murowany, został konsekrowany w 1773 r. przez biskupa sufragana włocławskiego Cypriana Wolickiego. Prawo patronatu należało do norbertanek z Żukowa. Opis stanu aktualnego świątyni, jej wyposażenia w to, co potrzebne do nabożeństw, ołtarzy i obrazów. Bractwo św. Barbary. Kaplic, nawet dysydenckich, nie było. Przytułku nie było, zaś szkoła, chociaż był pewien fundusz rządowy na nią, praktycznie nie funkcjonowała, k. 143-145v.

${ }^{95}$ Odpowiedzi dotyczące parafii Rumia i opis kościoła w Redzie sporządzone tą samą ręką, zapewne przez proboszcza Łyśniewskiego.

${ }^{96}$ Jest to karta tytułowa tego protokółu. 
Wykaz tabelaryczny parafii w Oksywiu. Wsie: Oksywie liczyło 186 katolików, z czego spowiadało się na Wielkanoc 134, akatolików, ani Żydów nie było; Chylonia 79, 57, -; Cysowa 56, 39, 4; Gdynia 152, 113, 2; Obłuże 162, 101, -; Pogórze 115, 94, -; Dembogórze 149, 105, -; Kossakowo 80, 66, -; Pierwoszyn 80, 51, -; Mosty 96, 75, 12; Michelinka 93, 73, -; Rewa 125, 91, -; Wysokie Redłowo 14, 9, 5; Witomino 30, 22, 7; Chwarzno 10, 8, 1. Ogółem katolików 1441, spowiadających się na Wielkanoc 1038, akatolików 32, Żydów nie było, k. 144.

Sposób sprawowania sakramentów, k. 145v-146v.

Proboszcz, z tytułem prepozyta, Łukasz Krzykowski. Parafiąjednak zarządzał Jan Bekier. Innych kapłanów nie było. Organista Michał Kruza. Krótka charakterystyka stanu moralnego parafian, k. 146v-148.

Stan ekonomiczny parafii, wykaz pobieranej dziesięciny, a także dochodów i rozchodów. Dokładny opis świątyni parafialnej. Spis paramentów liturgicznych i innego sprzętu kościelnego. Stan zabudowań plebańskich i inwentarz gospodarczy, k. 148-150.

Kościół filialny w C h y 1 o n i i. Świątynia pod wezwaniem św. Mikołaja. Prawo patronatu należało do Przebendowskiego. Opis kościoła, wyposażenia, ołtarzy o obrazów. Nie było żadnego bractwa, przytułku, ani szkoły, k. 150v-151.

Sposób sprawowania sakramentów, k. 151-151v.

Proboszcz ten sam, co w Oksywiu, a więc Jan Krzykowski, i za niego także tu sprawował duszpasterstwo, jako zarządca, Jan Bekier, k. 151v.

Kościół miał pewne uposażenie, wprawdzie nie zapisy, ale kilka domów oraz ziemię, co proboszcz wydzierżawił osobie świeckiej. Opis świątyni, której prezbiterium było murowane, a nawa z pruskiego muru, natomiast dzwonnica drewniana,. Wykaz niezbędnych paramentów liturgicznych. Budynki plebańskie w złym stanie. Inwentarza żadnego nie było, k. 152-153.

Protokół powizytacyjny dla parafii w Oksywiu i filii w Chylonii z dnia 16 III $1781 \mathrm{r}$. podpisany przez wizytatora i sekretarza, k. 153.

Dekret reformacyjny z dnia 20 VII 1782 r. wystawiony i podpisany przez wizytatora oraz podpisany przez sekretarza, k. $154-154 \mathrm{v}$.

Odpowiedzi na pytania postawione podczas wizytacji parafii Oksywie w 1781 roku, spisane zapewne przez zarządzającego parafią Jana Beker, k. 155-161v.

Opis kościoła parafialnego w Oksywiu i inwentarz paramentów liturgicznych, k. 162-163.

Opis kościoła parafialnego w Chylonii (nie dokończony), k. 163-163v ${ }^{97}$.

\section{[Dekanat gdański]}

Wykaz tabelaryczny dekanatu gdańskiego, do którego należały parafie: Kłodawa, Pręgowo, Mierzeszyn, Żukowo, Kielno, Chwaszczyno, Matarnia, Oliwa, Święty Wojciech, Łęgowo, k. 164.

${ }^{97}$ Zarówno odpowiedzi na pytania dotyczące parafii w Oksywiu, jak i opis kościoła w Chylonii sporządziła ta sama ręka, zapewne zarządcy Jana Beker. 
Opis dekanatu gdańskiego oraz wykaz tabelaryczny, tej samej treści co poprzedni, k. $165-170^{98}$.

Dekret reformacyjny dla dekanatu gdańskiego, sporządzony 4 III 1782 r. przez wizytatora i przezeń oraz przez sekretarza podpisany, k. 171-171v.

K ł o d a w a. Wizytacja kościoła parafialnego w Kłodawie. Kościół pod wezwaniem św., Jakuba, zaś patronem parafii był św. Michał Archanioł. Świeckiego prawa patronatu, ale dawniej należało ono do klasztoru cystersów w Lądzie. Opat lądzki też, Łukomski, w 1735 r. wzniósł tu świątynię murowaną, konsekrowaną w 1769 r. przez sufragana włocławskiego Cypriana de Komorze Wolickiego ${ }^{99}$. Stan świątyni, tu opisany, aktualnie dobry. Zakrystia wyposażona we wszystko potrzebne do nabożeństw. Opis ołtarzy, obrazów. Bractwo Szkaplerza z aprobata Stolicy Apostolskiej. Kaplicy żadnej w parafii nie było. Także akatolicy nie posiadali własnego zboru, a chowali się na cmentarzu na wyznaczonym miejscu. W szkole parafialnej uczył nauczyciel Józef Kitowski, wynagradzany przez rodziców dzieci, których uczył. Przytułek na czterech ubogich, którzy żyli z jałmużny, k. $173-175 \mathrm{v}$.

Wykaz tabelaryczny parafii Kłodawa. Wsie należące do parafii: Kłodawa licząca 100 katolików, w tym 89 spowiadających się i 6 akatolików; Zławieś 45, 37, 7; Hamer 25, 17, 14; Żukcin 91, 77, 13; Kleszczewko 84, 70, 6; Ulkowy 84, 60, 10; Łaguszewo 160, 130, 5; Zakrzewko 22, 16, 5; Kłobuczewo 25, 20, 21; Kacki 60, 50, 2; Trąbki Małe 56, 45, -. Ogółem wiernych 752, z czego na Wielkanoc spowiadało się 620 osób, a ponadto na terenie parafii mieszkało 72 akatolików. Żydów nie było, k. 174.

Sposób sprawowania sakramentów, k. 175v-177,

Proboszcz Adam Mikołajewski. Organista Bartłomiej Kitowski. Wikariusz zz zakonu dominikanów, Donat Bartnicki. Witrykusi Michał Paca i Wawrzyniec Słoniek. Krótka charakterystyka parafian, k. 177-178v.

Stan ekonomiczny parafii. Wykaz pobieranych dziesięcin oraz dochodu i rozchodu. Opis świątyni w dobrym się znajdującym stanie. Wykaz paramentów liturgicznych, w tym także tych, które były własnością bractwa. Opis plebanii wystawionej w pruski mur oraz pozostałych zabudowań. Wykaz inwentarza żywego i martwego. Szpital, bardzo stary, wymagał wystawienia nowego, k. 178v-181v.

Protokół wystawiony w Kłodawie dnia 8 III 1781 r. podpisany przez wizytatora i sekretarza, k. $181 \mathrm{v}$.

Dekret reformacyjny dla kościoła parafialnego w Kłodawie wystawiony dnia $3 \mathrm{~V} 1782 \mathrm{r}$. podpisany przez wizytatora i sekretarza, 182-182v.

Odpowiedzi na 327 pytań postawionych podczas wizytacji parafii Kłodawa w 1781 r., zapewne spisane przez proboszcza lub wikariusza. Wykaz tabelaryczny, identyczny z tym, który na karcie 174 został umieszczony, k. 183-192.

\footnotetext{
${ }^{98}$ Prezentacja dekanatu sporządzona w dwóch, prawie identycznych opisach.

${ }_{99}$ Biogram tego sufragana włocławskiego zob. Chodyński, Biskupi sufragani włocławscy, Włocławek 1906, s. 86-88.
} 
Pr ę g o w o i Ż u ła w a. Wizytacja kościoła parafialnego w Pręgowie i filialnego Żuławie w 1781 r., k. 194.

Wizytacja kościoła parafialnego w Pręgowie. Świątynia pod wezwaniem Bożego Ciała, patronatu królewskiego, złączona z kaplicą królewską w Gdańsku. Stan aktualny świątyni dobry, posiadający wystarczające wyposażenie. Opis ołtarzy o obrazów, Bractwo Bożej Opatrzności zaprowadzone za zgodą Stolicy Apostolskiej, posiadające pewne uposażenie. Kaplica publiczna we wsi Ciepielsk, gdzie kapelanem był Józef Brzeski jezuita. Oratoria dwa, jedno we dworze Kazimierza Zboińskiego w Domachowie, drugie zaś we dworze Trembeckich w Żuławce. Kapelanem w Żuławce był Andrzej Bielski, wikariusz ze Skarszew, który jednak tu sprawował msze w niedziele i święta. Protestanci nie mieli swojej kaplicy, a chowali się w polu, chociaż na cmentarzu parafialnym znajdowało się wydzielone dla nich miejsce. Przytułku nie było. W Ciepielsko znajdowała się szkoła, gdzie uczył niejaki Antoni Wenda, k. 194-196v.

Wykaz tabelaryczny parafii Pręgowo. Wsie: Pręgowo liczyło wiernych 66, spośród których spowiadało się na Wielkanoc 46, akatolików nie było; Bielkowo z przyległościami 153, 115, 15; Bielkówko z przyległościami 137, 74, 9; Ciepielsk z przyległościami 216, 132, 30; Górna Huta 26, 16, 14; Dolna Huta jedynie 8 akatolików; Marszowy 16, 6, 7; Ostroszki 890, 44, -; Górny Rząbsz z przyległościami 73, 55, 4; Dolny Ząbszcz 33, 27, 4; Sztangwaldt z przyległościami 83, 53, 11; Zaskoczyn z przyległościami 60, 40, 6; Żuławka z przyległościami 188, 134, 5; Czerniewo z przyległościami 103, 69, 17; Graniczna Wieś 18, 10, 32; Kleszczewo z przyległościami 160, 123, 11; Górne Buszkowy i Dolne Buszkowy 198, 90, 52; Goszyn 38, 23, 21; Lisewo 65, 39, 12; Baszkowo 70, 31, 26; Domachowo $66,38,8$. Ogółem zatem było wiernych 1869, spowiadających się 1175 i 291 akatolików. Żydów nie było, k. 195.

Sposób sprawowania sakramentów, k. 196v-197v.

Proboszczem był Maciej Grzegorz Garnysz, ${ }^{100}$ biskup sufragan włocławski, prepozyt kapituły włocławskiej i oficjał gdański, ale w parafii nigdy nie rezydujący. Parafią zarządzał Andrzej Miszewski. Przy kościele filialnym w Żuławce rezydował Andrzej Bielski, zaś przy kaplicy w Ciepielsku kapelanem był Józef Brzeski. Organistą był Andrzej Niezalewski. Zakonników nie było. Krótka charakterystyka parafian, k. $197 \mathrm{v}-198 \mathrm{v}$.

Stan ekonomiczny parafii Wykaz pobieranych dziesięcin oraz dochodu i rozchodu. Opis świątyni, wystawionej z kamienia i jej wnętrza. Spis paramentów liturgicznych. Dokładny opis plebanii i pozostałych zabudowań, w tym mieszkania organisty, karczmy młyna należącego do parafii. Ponadto do parafii należał folwark zwany Popówka, gdzie też były pewne zabudowania, k. 198v-201v.

Kościół filialny w we wsi Ż u ła w k a. Nosił wezwanie św. Małgorzaty, był dobrze utrzymany i posiadał wystarczające wyposażenie w potrzebne utensylia, $\mathrm{k}$. 202-202v.

Sposób sprawowania sakramentów, k. 202v-203.

${ }^{100}$ Biogram tego biskupa zob. Chodyński, Biskupi, s. 88-90; Nitecki, Biskupi Kościoła w Polsce 965-1999, Warszawa 2000, kol. 109. 
Wprawdzie był to kościół filialny i za duszpasterstwo odpowiadał zarządca z Pręgowa Andrzej Miszewski, ale w Żuławce nabożeństwa sprawował wspomniany wyżej kapelan przy dworze Jana Trembeckiego, Andrzej Bielski, k. 203.

Stan ekonomiczny tego beneficjum był niewielki, ponieważ specjalnego uposażenia nie było, jedynie cztery łany ziemi, uprawianej przez dziedzica Żuławki. Kościół ten posiadał wystarczające wyposażenie w paramenty liturgiczne, dokładnie wyliczone, k. 203-204.

Protokół wystawiony w Pręgowie dnia 11 III 1781 r., podpisany przez wizytatora i sekretarza, k. 204-204v.

Dekret reformacyjny dla kościoła w Pręgowie, z dnia 20 V 1782 r. podpisany przez wizytatora i sekretarza, k. 205.

Wykaz tabelaryczny parafii Pręgowo, zgadzający się tabelą wyżej omówioną, k. 206.

Wizytacja kościoła parafialnego w Pręgowie, przeprowadzona 11 III $1781 \mathrm{r}$. Jest ona dosłownie tej samej treści, co wyżej podawany protokół. Spisał to wszystko w dniu 11 III 1781 r. Andrzej Miszewski, zarządzający parafią, k. 207-213v.

Wizytacja generalna kościoła w Żuławce przeprowadzona dnia 9 III $1781 \mathrm{r}$. Spisane to zapewne zostało przez rezydującego w Żuławce Andrzeja Bielskiego, k. $214-215 \mathrm{v}$.

M i e r z e s z y n. Wizytacja kościoła parafialnego w Mierzeszynie. Świątynia pod wezwaniem św. Bartłomieja. Prawo patronatu należało do króla pruskiego. Stan świątyni dobry, należycie wyposażona w potrzebne utensylia. Opis ołtarzy i obrazów. We wsi Przywidz kaplica publiczna pod wezwaniem św. Ksawerego, której kolatorem był Franciszek Trzciński. Przy tej kaplicy rezyduje, za zgodą władzy kościelnej, zarządzający parafią w Mierzeszynie Andrzej German, co było korzystne dla parafian. Przytułku nie było. Szkoła parafialna, gdzie człowiek świecki, Krystian Arniko, uczył czytania, pisania i podstaw wiary 12 uczniów, k. 216-219.

Wykaz tabelaryczny parafii Mierzeszyn. Wsie: Mierzeszyn liczył 90 katolików, z czego spowiadało się 50 osób. Akatolików (tylko w Mierzeszynie) było 300; Przywidz 40, 30; Nieder Klonau 3, 3; Ober Klonau nie miał mieszkańców; Michels Helt 9, 9; Aklt Helt 3, 2; Katarynke 4, 2; Pumlau 1, 1; Glaszberg i Schoenberg nie posiadały mieszkańców. Zatem ogółem było 120 wiernych, spowiadających się 94 oraz 300 akatolików, k. 218.

Sposób sprawowania sakramentów, k. 219-220.

Zarządzał parafią Andrzej German, jednak po polsku mówiący częściowo, bo pochodził z diecezji warmińskiej, nierezydujący w Mierzeszynie, ale przy kaplicy Przywidzu, za zgodą władzy kościelnej i co było z wygodą dla parafian. Do kościoła parafialnego przybywał $\mathrm{w}$ co trzecią niedzielą $\mathrm{i} \mathrm{w}$ święta ${ }^{101}$. Był organista, ale nie podano nazwiska. Krótka charakterystyka parafian, k. 220-221v.

Stan ekonomiczny parafii. Były 4 łany ziemi. Zamiast dziesięciny proboszcz otrzymywał składkę pieniężna. Zapisów pobożnych na kościół nie było. Ziemię

${ }^{101}$ W Mierzeszynie bowiem zamieszkiwali prawie sami innowiercy. 
dzierżawił niejaki Krystian Barciński. Spis paramentów kościoła w Mierzeszynie. Plebania nowo wystawiona przez zarządcę, ale jeszcze nieukończona, podobnie jak budynek inwentarski, k. 221v-222v.

Wykaz paramentów w kaplicy w Przywidzu. Dom rektora w Przywidzu, a także i pozostałe zabudowania, nie naprawy, ale nowego wystawienia potrzebują, $\mathrm{k}$. $222 \mathrm{v}-223$,

Protokół podpisany w Mierzeszynie dnia 10 III $1781 \mathrm{r}$. przez wizytatora i sekretarza, k. 223.

Dekret reformacyjny dla kościoła parafialnego w Mierzeszynie, wystawiony 9 V 1782 r, k. 224-224v.

Odpowiedzi na pytania postawione podczas wizytacji parafii Mierzeszyn w 1781 r., k. 225-231 ${ }^{102}$.

Ż u k o w o. Wizytacja kościoła parafialnego w Żukowie w 1781 r. Świątynia pod wezwaniem św. Jana Chrzciciela, murowana, zaś prawo patronatu należało do zakonnic norbertanek z Żukowa. Krótki opis tanu świątyni, jej wyposażenia w to, co potrzebne do nabożeństw, ołtarzy i obrazów. Bractwa żadnego nie było. Kaplica w klasztorze sióstr, murowana. W dobrach podkomorzego Wolskiego w Niestępowie i dobrach starosty starogardzkiego Tczewskiego w Tokarach znajdowały się kaplice, posiadające indult na msze, jednak tak, aby nie sprzeciwiało się to prawom parafii. Nie było osobnych kapłanów, ale zapraszano zakonników, zaś w dni świąteczne sami dziedzice brali udział a nabożeństwach w kościele parafialnym. W Żukowie szkoła parafialna, gdzie uczył katolik, ale zmarł przed kilkoma miesiącami. Nie ma następcy, stąd i nie ma uczniów. Ale było przewidziane przez władze utrzymanie dla nauczyciela. W Żukowie przy klasztorze jest dom zbudowany przez 30-toma laty jako przytułek, gdzie znajdowało się sześć wdów, ale nie było żadnego uposażenia, stąd podopieczne były na utrzymaniu klasztoru i tego, co dostaną jako jałmużnę. Przytułku dla chorych nie było, k. 232-235.

Wykaz tabelaryczny parafii Żukowo. Wsie: Żukowo liczyło 323 wiernych, z czego spowiadało się 247 osób, zaś akatolików było 17; Pempowo 10, 73, 5; Rębiechowo 52, 40, -; Lezenko 95, 73, -; Lezno 95, 73, -; Lniska 85, 65, 7; Niestępowo 46, 36, 88; Ottominko 9, 7, 17; Rembowo 19, 14, 4; Sulmino 37, 26, 24; Przyjaźń, 13, 13, 100; Otomino 43, 34, 3; Lühtefeldt 14, 11, 39; Skrzeszewo 111, 81, 32; Glincz Stary 27, 22, 24; Glincz Szlachetny z Hamer Pustkowie 56, 45, 6; Borkowo 80, 61, 6; Pikarnia 60, 44, 2; Dzierzązno 78, 58, 4; Mezowo 33, 24, 5; Sitno 14, 11, 8; Kczewo 60, 38, 8; Tokary 109, 79, 4; Czeczawa 43, 34, -; Małkowo 77, 68, 4; Mniszewo 34, 27, 15, k. $234^{103}$.

Sposób sprawowania sakramentów, k. 235-235v.

Proboszczem i spowiednikiem zakonnic norbertanek był Łukasz Jan Krzykowski, kanonik kruszwicki ${ }^{104}$, dziekan gdański i zarządzający parafią Oksywie,

\footnotetext{
${ }^{102}$ Odpowiedzi te, to właściwie powtórzony protokół wizytacyjny, tyle iż spisany prawdopodobnie ręką zarządzającego parafią.

${ }^{103}$ Prawdopodobnie dół tabeli został obcięty, bo na to wskazuje jej stan, stąd nie ma podsumowania.

${ }^{104}$ Nie zna go w Swoim Katalogu prałatów i kanoników kruszwickich Antoni Fiutak.
} 
w Żukowie nie rezydujący. W parafii pracowali dwaj wikariusze Andrzej Piechowski i Józef Becker. Organista Stanisław Jankowski i Witrykusi Jakub Głąbiowski, Bartłomiej Szymik i Andrzej Jentz. W Zukowie klasztor norbertanek Krótka charakterystyka parafian, k. 235v-236v.

Stan ekonomiczny parafii. Były pewne zapisy. Cztery Łany ziemi. Meszne pobierano z wsi parafialnych, tu wyliczone. Opis wyglądu świątyni parafialnej, w stanie dobrym. Wykaz paramentów liturgicznych. Inwentarza gospodarczego nie było, k. 236v-238.

Protokół wizytacyjny podpisany w Zukowie dnia 12 III 1781 r. przez wizytatora i sekretarza, k. 238.

Dekret reformacyjny dla parafii w Żukowie, wystawiony 4 V 1782 r. i podpisany przez wizytatora i sekretarza, k. 239-239v.

Odpowiedzi na pytania wizytacyjne dane przez proboszcza podczas wizytacji $1781 \mathrm{r}$. Odpowiedzi na poszczególne, w liczbie 328, pytania, spisane pięknym pismem, podpisane osobiście przez proboszcza Łukasza Jana Krzykowskiego, k. 241-246v.

K i e 1 n o i S z y n w a łd. Wizytacja kościoła parafialnego w Kielnie i filialnego w Szynwałdzie, w 1781 r. przeprowadzona. Świątynia pod wezwaniem św. Wojciecha,murowana, wystawionadziękiróżnymdobrodziejomizjałmużnyw 1752 r.. Prawo patronatu należało do króla pruskiego. Jednak aktualnie nie wyglądała dobrze i wołała o naprawę. W zakrystii paramenty liturgiczne. Opis pięciu ołtarzy i obrazów. Bractwo Szkaplerza zaprowadzone za zgoda Stolicy Apostolskiej. Szkoły, ani przytułku nie było. Organista w czasie zimowym uczył dzieci, k. 247-250 .

Wykaz tabelaryczny parafii Kielno. Wsie: Kielno liczące 150 wiernych, spowiadających się 128 oraz na terenie wsi mieszkało 2 akatolików; Głażyca i Grabowiec z przyległościami 104, 78, -; Czernica Głodówko 20, 15, -; Dębowa z przyległościami 17, 11, 7; Warzno z przyległościami 114, 93, 4; Szynwałd z przyległościami 203, 155, 9; Kłosowa z przyległościami 51, 43, 12; Kłosówko i Kowalewo 69, 56, 14; Kolleczkowo z przyległościami 68, 54, 2; Bieszkowice z przyległościami 55, 49, -; Okuniewo 18, 16, -; Głodowo z przyległościami 18, 16, -; Wyczlin z przyległościami 124, 112, 14; Bojanie 43, 33, 4; Dobrzewin i Karczemki 43, 34, 10; Miszewo z przyległościami 23, 18, 6; Warzenko 22, 17, 11; Donimierz Wielki 60, 54, 31; Donimierz Mały 42, 35, 8; Piekiełko z przyległościami 13, 11, 3. Ogółem w parafii było katolików 1154, spowiadających się na Wielkanoc 1028 oraz na Terenia parafii mieszkało 137 akatolików. Żydów nie było, k. 249.

Sposób sprawowania sakramentów, k. 250-251.

Proboszcz Stanisław Stypczyński, rezydujący na miejscu. Innych kapłanów nie było. Organista niepodanego nazwiska. Krótka charakterystyka parafian, k. 251-252v.

Stan ekonomiczny parafii. Wykaz pobieranej dziesięciny. Wykaz dochodów i rozchodów. Dokładny opis świątyni. Spis inwentarza kościelnego. Opis zabudowań plebańskich i inwentarz gospodarczy, k. 252v-254v. 
Kościół filialny S z y n w a łd. Świątynia pod wezwaniem św. Mikołaja. Prawa patronatu należało do króla pruskiego. Opis stanu tej świątyni drewnianej, ołtarzy, a także wyposażenia w sprzęty kościelne. Bractwo św. Barbary, posiadające potwierdzenie Stolicy Apostolskiej. Na miejscu kościoła [zapewne dawnego], przy drodze publicznej i cmentarzu, znajdowała się kaplica, także pod wezwaniem św. Mikołaja, ale w niej nie odbywały się nabożeństwa. Szkoły, ani przytułku nie było. Sposób sprawowania sakramentów tak jak w kościele parafialnym. Proboszcz ten, co w Kielnie. Stan ekonomiczny beneficjum w Szynwałdzie. Dosyć dokładny spis inwentarza kościelnego, w tym także rzeczy będących własnością bractwa, k. 255-257.

Protokół powizytacyjny podpisany w Kielnie, dnia 14 III 1781 r, przez wizytatora i sekretarza, k. 257.

Dekret reformacyjny dla kościoła parafialnego w Kielnie, wystawiony dnia 8 V 1782 r. ${ }^{105}$.

Wizytacja kościoła parafialnego w Kielnie, odbyta w 1781 r. Są to odpowiedzi na pytania, także odnoszące się do kościoła filialnego, sporządzone osobiście przez proboszcza Stanisława Stypczyńskiego i przezeń osobiście podpisane, k. $259-268 \mathrm{v}$.

P r z o d k o w o. Wizytacja kościoła parafialnego w Przodkowie w $1781 \mathrm{r}$. odbyta. Świątynia, częściowo drewniana, częściowo z pruskiego muru, pod wezwaniem św. Andrzeja Apostoła. Prawo patronatu należało do króla pruskiego. Jest ta parafia złączona z parafią w Kielnie. Stan świątyni wymagający naprawy. Zakrystia wyposażona w potrzebne paramenty. Opis ołtarzy i obrazów. We dworze Załęże, należącym do Jakuba Łebińskiego, kaplica prywatna, ale nie narusza ona prawa parafialnego kościoła. Akatolicy własnej kaplicy, ani cmentarza nie posiadali i chowali się na wydzielonej części cmentarza parafialnego. Szpitala nie było. Szkoła parafialna działała w zimie i uczył organista, k. 269-272.

Wykaz tabelaryczny parafii Przodkowo. Wieś Przodkowo liczyła 82 wiernych, z czego spowiadało się na Wielkanoc 57 osób, zaś akatolików mieszkało na terenie wsi 2; Smałdzyn 69, 55, -; Młynik 24, 19, 9; Kobusewo z kolonią Grzybna i Krymka 99, 79, 15; Kossowo 125, 92, -; nowe kolonie Grzybna i Ucisk 10, 7, 16; Załęże 49, 39, 3; Pomieczyno z koloniami Trzy Rzeki i Rąb 48, 43, 6; kolonia Barnik 9, 7, 3; Hoppy i Buterfas 25, 22, -; Szarlota z nowa kolonią Gliniana Góra 99, 40, 6. Ogółem zatem było 639 wiernych, spowiadających się 464, akatolików mieszkało na terenie parafii 60. Żydów nie było, k. 271.

Sposób sprawowania sakramentów, k. 272-273.

Zarządcą parafii był Michał Mateusz Józef Jentz. Na terenie parafii, we wsi Młynik, mieszkał kanonik kruszwicki Michał Tczewski. Był organista, ale nazwiska Anie podano. Krótka charakterystyka parafian, k. 273-274v.

Stan ekonomiczny parafii. Wykaz pobieranych dziesięcin. Dochody i rozchody. Plebania i zabudowania plebańskie w stanie złym. Świątynia przodkowska

${ }^{105}$ Nie wspomniano tu o kościele filialnym w Szynwałdzie. 
także raczej nowego wystawienia, aniżeli reperacji oczekuje. Spis paramentów liturgicznych, k. 274v-276.

Protokół powizytacyjny podpisany w Przodkowie dnia 10 III 1781 r. przez wizytatora i sekretarza, k. 276.

Dekret reformacyjny dlakościoła parafialnego w Przodkowie, wystawiony 5 VII 1782 r., podpisany przez wizytatora i sekretarza, k. 277.

Odpowiedzi na pytania postawione podczas wizytacji generalnej kościoła w Przodkowie, odbytej 13 III 1781 r., k. 278-286v ${ }^{106}$.

C h w a s z c z y n o. Wizytacja kościoła parafialnego we wsi Chwaszczyno i filialnego w Kacku w 1781 r. odbyta. Świątynia pod wezwaniem Świętych Apostołów Szymona i Judy. Prawo patronatu należało do miejscowego ordynariusza. Kościół, wybudowany z pruskiego muru, znacznie zniszczony i wymagający naprawy. Zakrystia wyposażona w paramenty liturgiczne. Opis trzech ołtarzy i obrazów. We wsi Kolebki oratorium publiczne w dobrach Przebendowskiego. Była dawna umowa, że Proboszcz z Chwaszczyna będzie tu sprawował nabożeństwa każdej niedzieli i w święta, ale teraz nie odprawia. Przy kaplicy tej jest jako kapelan zakonnik franciszkanin z Wejherowa, ale prawa parafii nie są tu naruszane. Akatolicy V swój zbór we wsi Małe Kacki. Żydów i eremitów nie było, Przytułku nie było. We wsi Wielkie Kacki (Kack), przy kościele filialnym, organista Franciszek Halman uczył około 15 dzieci, k. 287-289.

Wykaz tabelaryczny parafii Chwaszczyno. Wieś Chwaszczyno liczyło 145 katolików, z czego 98 spowiadających się na Wielkanoc oraz mieszkało tu 7 akatolików; Wielkie Kacki z Kociołem filialnym 192; 102, 9; Małe Kacki 66, 40, 148; Wielki i Mały Tuchom 85, 66, 10; Karczemki 5, 3, -; Kolebki 212, 141, 67. Ogółem zatem było 707 wiernych, z czego spowiadających się 450, a akatolików w parafii mieszkało 241. Żydów nie było. k. 288.

Sposób sprawowania sakramentów 289v-290v.

Proboszcz Antoni Józef Grochowski. Kapelan przy kaplicy w Kolebkach. Organista Franciszek Halman. Opinia o parafianach, k. 290vo291v.

Stan ekonomiczny parafii. Parafia posiadała cztery łany ziemi, pobierano dziesięcinę w zbożu i inne jeszcze dochody. Wykaz dochodów i rozchodów. Opis dokładny świątyni w Chwaszczynie, z pruskiego muru, potrzebującego naprawy. Spis inwentarza kościelnego. Stan zabudowań plebańskich oraz spis inwentarza gospodarczego, k. 291v-292 ${ }^{\mathrm{a}} \mathrm{v}^{107}$.

Kościół filialny w K a c k u. Wieś ta nosiła nazwę Wielki Kack i miała świątynię pod wezwaniem św. Wawrzyńca. Wymagała ona naprawy. Prawo patronatu, jak i parafii Chwaszczyno, należało do miejscowego ordynariusza. Opis świątyni i jej wyposażenia w paramenty liturgiczne, jej ołtarze i obrazy. Bractwa żądnego nie było, podobnie jak i przytułku. W szkole parafialnej uczył organista. Ubodzy żyją po wsi z jałmużny, k. 293.

Sposób sprawowania sakramentów, k. 293v-294.

${ }^{106}$ Odpowiedzi te, bardzo dokładne, nie zostały podpisane, ale najprawdopodobniej sporządził je sam proboszcz z Przodkowa.

${ }^{107}$ Przy foliacji pomyłkowo zapisano podwójnie kartę 292. 
Duszpasterstwo sprawuje proboszcz z Chwaszczyna, Antoni Józef Grochowski, odprawiając kolejno msze w jedna niedzielę Chwaszczynie, w druga w Kacku, k. 294-294v.

Stan uposażenia kościoła. Były tu cztery Łany ziemi, przez proboszcza wydzierżawione. Dokładny opis świątyni, wystawionej w pruski mur, wymagającej naprawy. Wykaz inwentarza kościelnego. Inwentarza gospodarczego nie było, k. $294 \mathrm{v}-295 \mathrm{v}$.

Protokół powizytacyjny podpisany w Chwaszczynie, dnia 20 III 1781 r. przez wizytatora i sekretarza, k. 295v.

Dekret reformacyjny dla kościoła parafialnego w Chwaszczynie i filialnego w Kacku, wystawiony 16 V 1782 r. i podpisany przez wizytatora i sekretarza, k. 296-296v.

M a t a r n i a. Wizytacja kościoła parafialnego w Matarni, odbytej w 1781 r. Świątynia nosi wezwanie św. Walentego. Prawo patronatu należało do opata z Oliwy. Kościół wymagał naprawy. Był jednak należycie wyposażony w paramenta kościelne. Opis ołtarzy i obrazów. Uważano, że obraz św. Walentego był łaskami słynący. Dawniej była kaplica we wsi Banino, gdzie były nawet cztery łany ziemi, teraz należące do parafii w Matarni. Przytułku nie było. W szkole parafialnej uczył niejaki Józef Gutkowski, k. 298-300v.

Wykaz tabelaryczny parafii Matarnia. Wieś Matarnia liczyła 90 wiernych, w czym 61 osób spowiadało się, akatolików nie było; Klukowo 35, 26, 3; Barniewiec 67, 49, 1; Banino 40, 34, 11; Matemblewo z kolonia Jeden Róg, Trzy Rogi, Złota Karczma 41, 31, -; Kokoszkowy i Karczemki 161, 111, 1; Smogorzyn, Żabianka i Kołpinek 68, 49, 2; Ołpin z kolonia Jakubowo 61, 49, 9; Kolberg 3, 2, -; Byszewo z kolonią Firoga ${ }^{108} 40,32$, -; Nenkowy 53, 42, 7; Czaple 18, 8, -; Borowiec 10, 6, 2. Ogółem w parafii było 987 katolików, w tym spowiadających się na Wielkanoc 500, zaś akatolików naliczono 36, k. 299.

Sposób sprawowania sakramentów, k. 300v-301v.

Zarządca parafii był Kwirynus Doryng. Innych kapłanów nie było. Organista Paweł Gutkowski. Krótka charakterystyka parafian, k. 301v-302v.

Stan ekonomiczny parafii. Pobierano dziesięcinę w ziarnie. Wykaz dochodów i rozchodów. Dokładny opis murowanej świątyni w Matarni. Spis inwentarza, to jest paramentów liturgicznych i innego sprzętu kościelnego. Dokładny opis zabudowań plebańskich, k. 302v-304v.

Protokół powizytacyjny spisany w Matarni dnia 27 III 1781 r. i podpisany przez wizytatora i sekretarza, k. 304v-305.

Dekret reformacyjny dla kościoła w Matarni, wystawiony 1 VII 1782 r., podpisany przez wizytatora i sekretarza, k. 306-306v.

Odpowiedzi na pytania stawiane podczas wizytacji generalnej Kocioła parafialnego w Matarni w 1781 r., k. 308-312 $\mathrm{v}^{109}$.

${ }^{108}$ Lekcja niepewna.

${ }^{109}$ Odpowiedzi niepodpisane, ale zapewne spisane przez zarządzającego parafią księdza Kwiryna Dyryng. 
Św ięty Woj c i e ch. Wizytacja kościoła parafialnego w we wsi Święty Wojciech, odbyta w 1781 r. Świątynia pod wezwaniem św. Wojciecha, murowana, której kolatorem był przełożony generalny Zgromadzenia Misjonarzy [św. Wincentego á Paulo], aktualnie Antoni Jacquier. Opis świątyni, jej podstawowego wyposażenia, jej ołtarzy i obrazów. Kościół ten posiadał wiele relikwii, na czele z relikwiami Krzyża Świętego, na co było potwierdzenie urzędowe z 1736 r. Bractwo św. Józefa potwierdzone w 1732 r. kaplica na górze w lesie, pod wezwaniem św. Wojciecha, bez własnego uposażenia i wyposażenia, gdzie w uroczystość Dni Krzyżowych i św. Wojciecha sięodprawia, a paramenty liturgiczne brane były zkościoła parafialnego. Ponadto dwie kaplice prywatne w domach szlacheckich. We dworze Raszyn, należącym do Piwnickich, znajdowała się kaplica wyposażona w potrzebne paramenty, mająca indult na sprawowanie mszy, gdzie kapelanem był karmelita Bogusław. Druga kaplica we wsi Straszyn w dobrach Michała Skórzewskiego, wprawdzie też posiadająca odpowiednie zezwolenie władzy kościelnej nas sprawowanie tam mszy, ale ponieważ nie było na miejscu właściciela, mszy też nie sprawowano. Akatolicy własnej kaplicy nie posiadali. Szkoły publicznej nie było, ale istniała szkoła parafialna, gdzie uczyła osoba świecka, mianowicie niejaki Jan Waschki. Przytułek, zbudowany przez Kongregacje Misjonarzy, dawał schronienie trzem wdowom, żyjącym z jałmużny i usługującej kościołowi, k. 314-317.

Wykaz tabelaryczny parafii Święty Wojciech. Miasto Święty Wojciech liczyło 449 wiernych, spowiadających się 342, zaś akatolików 112. Natomiast następujące wsie liczyły: Maćkowy 74, 55, 22; Maćkowskie grunta 12, 11, 13; Arciszewo 31, 25, 14; Borenty 16, 11, -; Będzieszyn 36, 31, 40; Straszyn 52, 41, 46; Rekszyn 62, 55, 8; Swintz i Zabianka 94, 74, -; Chudomin jedynie 8 akatolików; Berkfeldt 18, 12, 121; Tienffensec 7, 5, 26; Gołąbkowo 7, 5, 5; Janachowo 15, 10, 16; Prędzieszyn 36, 26, 43; Bartlin 6, 5, 6; Wojanowo 86, 66, 11; Jagatowo 9, 7, 17; Russocin Wielki 27, 17, 33; Rusocin Mały 3, 3, 23; Brozowka 7, 7, -; Herbert 9, 7, 23; Schynfeldt 7, 3, 11. Zatem ogółem w parafii było 1054 katolików, z czego spowiadających się 811, zaś na terenie parafii mieszkało 698 akatolików, k. 315.

Sposób sprawowania sakramentów, k. 317-317 a

Prepozytem przy tym kościele był Józef Rogali ze Zgromadzenia Księży Misjonarzy, ciagle ty rezydujący i zarządzający duszpasterstwem, wypełnianym jednak przez pomoc czterech księży z tegoż zgromadzenia, też na miejscu rezydujących. Kapłani owi to Wojciech Jabłonkowski, Szymon Graw, Franciszek Kolberg i Andrzej Bargell. Innych zakonników nie było. Krótka charakterystyka parafian, k. $317^{\mathrm{a}}-318 \mathrm{v}$.

Stan uposażenia beneficjum. Nie było specjalnych zapisów. Parafia posiadała ponad 4 łany ziemi, które w większej części uprawiano. Pobierano dziesięcinę w ziarnie, wyliczona tu według wsi ja oddającej. Wykaz dochodu i rozchodu. Opis murowanej wiatyki położonej przy rzeczce Raduni. Spis sprzętów kościelnych. Dom mieszkalny murowany. Inne zabudowania oraz folwark położony za rzeka Stara Radunią. Zabudowania plebańskie w dobrym stanie. Inwentarz gospodarczy, k. 318v-321. 
Protokół powizytacyjny podpisany w Świętym Wojciechu dnia 13 VIII 17891 r. przez wizytatora i sekretarza, k. 321-321v.

Dekret reformacyjny dla parafii św. Wojciech wystawiony dnia 6 VII $1782 \mathrm{r}$. i podpisany przez wizytatora i sekretarza, k. 322-322v.

Odpowiedzi na pytania postawione podczas wizytacji generalnej parafii Święty Wojciech w 1781 r., k. 323-330v.

Opis kościoła parafialnego Świętego Wojciecha przy Gdańsku. Oprócz opisu świątyni jest dokładny wykaz paramentów liturgicznych, argentariów, szat liturgicznych i ksiąg kościelnych ${ }^{110}$, k. 331-331 ${ }^{\text {a }}$.

Ł ę g o w o. Wizytacja kościoła parafialnego w Łęgowie odbyta w $1781 \mathrm{r}$. Kościół pod wezwaniem św. Mikołaja, którego kolatorem był opat z Oliwy, w stanie bardzo dobrym. Podobnie dobre wyposażenie zakrystii we wszystko, co potrzebne do nabożeństw. Opis czterech ołtarzy oraz obrazów. Wprawdzie było kolka relikwii, ale w większości są wattpliwości, co do ich autentyczności. Było uposażenie, zapisane przez dawnego proboszcza z Łęgowa i Różyn, na sprawowanie mszy fundowanej przy ołtarzu Natki Boskiej. Bractwo Różańcowe i drugie Najświętszego Imienia Jezus zaprowadzone za zgodą władzy kościelnej w $1750 \mathrm{r}$. Kaplic publicznych ani prywatnych nie było. Dawniej był kaplica-oratorium fundowana przez króla polskiego we wsi Grebin, gdzie odprawiali nabożeństwa zakonnicy cystersi z Oliwy, a nawet proboszcz z Łęgowa, jednak aktualnie ta kaplica została zniesiona przez króla pruskiego, zaś paramenty, jakie się w niej znajdowały, wróciły do cystersów z Oliwy. Akatolicy chowali zmarłych ma wydzielonym miejscu cmentarza, z wyjątkiem wsi Grabin. Szkoła parafialna w Łęgowie, gdzie 40 dzieci uczył świecki Józef Lipski i we wsi Skowarcz, gdzie dla 20 dzieci nauczycielem była także osoba świecka, Marcin Aleks. Przytułek dla trzech osób pochodzących z parafii, znajdował się w Łęgowie, zbudowany przez Iwona Rochweder, prepozyta $\mathrm{z}$ Łęgowa. Przytułek ten miał też pewne zapisy fundacyjne, k. 333-336.

Wykaz tabelaryczny parafii Łęgowo. Wieś Łęgowo liczyła 422 katolików, spośród których spowiadało się na Wielkanoc 317 oraz w parafii mieszkało 25 akatolików; Skowartz 232, 172, 8; Grabin 32, 32, 132; Rozenberg (Rozyny, gdzie był kościół filialny) 219, 185, 27. Zatem w parafii było ogółem 905 wiernych, 706 spowiadających się oraz mieszkało tu 192 akatolików, k. 334.

Sposób sprawowania sakramentów, k. 336-337v.

Proboszczem z tytułem prepozyta był Urban Müller, zakonnik cysterski, doktor teologii. Sam zarządzał parafią, ale głównie pracował jego wikariusz, którym był także zakonnik cysterski Uspianus Har. Organistą był Józef Lipski, zaś grabarzem niejaki Wawrzyniec. Innych kapłanów, ani zakonników w parafii nie było. Krótka opinia o parafianach, k. 237v-338v.

Stan ekonomiczny parafii. Posiadała ona pięć domów oraz dwa łany ziemi. Domy wydzierżawiano mieszkańcom. Wykaz dochodów pobieranych z poszcze-

${ }^{110}$ Ten opis został sporządzony inną ręka, niż poprzednie odpowiedzi, a przy obydwóch brak podpisów. Może sporządzili to pracujący tu kapłani, pomocnicy prepozyta? 
gólnych wsi. Do starania o dobry sta zabudowań beneficjum od dawna byli zobowiązani mieszkańcy wsi Łęgowo i Skowarcz, ale teraz zwyczaj ten ustał. Prepozyt sam uprawia wspomniane dwa łany. Na naprawy idą pieniądze składane do skarbony. Wykazdochodówirozchodów.Opisświątynimurowanej, wystawionejw 1743 r. przez proboszcza Iwona Rochweder, jego oraz Jacka Rybińskiego, opata oliwskiego staraniem. Wykaz paramentów liturgicznych. Stan zabudowań okazały, rezydencja proboszcza dwukondygnacyjna. Wznosił ja i inne wspomniany Iwo Rochweder. On także wzniósł szpital, k. 338v-342v.

Protokół powizytacyjny podpisał w Łęgowie, dnia 16 VIII 1781 r. wizytator i sekretarz, k. 342v.

R ó ż y n y. Wizytacja kościoła parafialnego Różyny w 1781 r, odbyta. Kościół pod wezwaniem św. Wawrzyńca, Prawo patronatu, ponieważ jest ta parafia złączona z parafia w Łęgowie, należało do opata oliwskiego. Świątynia murowana, wzniesiona w 1744 r. przez przeora oliwskiego i prepozyta w Łęgowie i Różynach Iwo Rochweder. Opis stanu świątyni i jej wyposażenia oraz ołtarzy o obrazów. Relikwie św. Wawrzyńca. Bractwo Matki Boskiej Bolesnej zaprowadzone w 1746 r. Innowiercy mieli swój cmentarz położony za wsią. Przytułku nie było. Szkoła parafialna nie miała żadnego funduszu też nie było, ale uczył człowiek świecki Marcin Aleks, k. 343-345v.

Sposób sprawowania sakramentów, k. 345v.

Proboszczem był Proboszcz z Łęgowa, Urban Müller, ponieważ parafia Różyny była inkorporowana do parafii Łęgowo. Msze tutaj odbywały się w druga niedziele i święta. Organista był Marcin Aleks, a grabarzem Michał Top. Charakterystyka parafian taka, jak w parafii Łęgowo, k. 346.

Stan ekonomiczny. Nie było żadnych legatów. Utrzymuje się z akcydensów i składek w świątyni. Były cztery łany ziemi, oddane przez proboszcza w dzierżawę na trzy lata niejakim Daniel Huss i Daniel Nau, pobierając opłaty. Ponadto był jeszcze ogród, oraz dochody z dziesięciny płaconej w ziarnie. Pewien dochód był też przeznaczony dla organisty. Dokładny opis świątyni parafialnej. Parafia postanowieniem biskupa włocławskiego Wawrzyńca Gembickiego dnia 17 X 1614 r. została inkorporowana do parafii Łęgowo i prawo patronatu zostało przeniesione na osobe opata oliwskiego. Zmiana ta została nawet zatwierdzona prze Stolice Apostolska, a odpowiednia bulla znajdowała się w archiwum oliwskim. Świątynia ta, zbudowana staraniem prepozyta Iwona Rochwweder, miała także darczyńcę Trembecką, która dała potrzebne drewno ze swoich lasów. Opis tej świątyni i jej wyposażenia w paramenty liturgiczne, k. 346-348v.

Protokół powizytacyjny spisany we wsi Łęgowo, dnia 15 IX 1781 r., podpisany przez wizytatora i sekretarza, k. 348v.

Dekret reformacyjna dla kościołów parafialnych w Łęgowie i Różynach, wystawiony 1 VI 1782 r., podpisany przez wizytatora i sekretarza, k. 349. 
Odpowiedzi na pytania postawione podczas wizytacji generalnej kościołów parafialnego w Łęgowie i filialnego w Różynach w 1781 r., k. 350 311 ,

Odpowiedzi dotyczące kościoła w Łęgowie na 328 pytań szczegółowych ${ }^{112}, \mathrm{k}$. $351-367 \mathrm{v}$.

Dodatek źródłowy, ujęty w 46 punktów, przytaczający zapisy proboszcza łegowskiego i niektóre dokumenty:

1. Zapis o budowie nowego kościoła przez prepozyta łęgowskiego, Iwo Rocweder, za zgodą ordynariusza miejscowego i opata oliwskiego, k. 368.

2. Dokument biskupa włocławskiego, Aleksandra Czapskiego, wystawiony w Gdańsku dnia 18 XI 1748 r., dla Iwona Rocweder, k. 368-368v.

3. Wiadomość o fundacji zegara na kościele oraz o dzwonach, k. 368v.

4, Treść epitafiów na ścianach kościoła e Łęgowie, k. 368v,

5-21 Wiadomości o stanie i wyposażeniu świątyni, k. 369-371.

22.-Dokument biskupa Czapskiego erygujący w 1750 r. bractwo różańcowe, k. $371-371 \mathrm{v}$,

23-32 Ciąg dalszy wiadomości o wyposażeniu kościoła.

33-35 opis wyposażenia ciagg dalszy oraz wiadomość o pieczęci parafialnej parafii Łęgowo i Różyny, k. 373.

36-43 wiadomość o uposażeniu parafii i rezydencji, k. 33v-374v.

45 Fundacja przytułku w Łęgowie przez prepozyta łęgowskiego Iwona Rocweder i Opara oliwskiego Jacka Rybińskiego w 1749 r., k. 374v-375.

46 Biskup Walenty Aleksaner Czapski dnia 21 II 1751 r. nadał tytuł prepozyta dla proboszcza Łęgowa i Różyny, Iwonowi Rocweder, na prośbę opata oliwskiego Jacka Rybińskiego, w uznaniu zasług położonych dla parafii Łęgowo i Różyny, k. 373-373v.

Dodatek dotyczący kościoła filialnego w Różynach, k. 376,

47. Wiadomość o inkorporacji kościoła w Różynach do Łęgowa, k.376.

48. Przeniesienie prawa patronatu parafii Różyny na opata oliwskiego, k. 376v.

49. Dokument inkorporacji parafii znajduje się w aktach oliwskich, k. 376.

50. Wiadomość o nowym kościele w Różynach stawianym przez Iwona Rocweder, dzierżawcę dóbr Rozyny Trembecką, z pomocą klasztoru oliwskiego, k. 376.

51. Budowa dzwonnicy, k. 376-376v.

52. Wystrój ściany frontowej świątyni w Różynach, k. 376v.

53. Na wieży umieszczono zegar, k. 376v.

54. Opis świątyni i zakrystii, k. 376v.

55-63. Opis wielkiego ołtarza, pozostałych ołtarzy i wystroju oraz ogólnego wyglądu wnętrza świątyni. 376v-377.

64-65. Wiadomości o bractwie matki Boskiej Bolesnej, k. 377.

66. Kościół w Różynach otrzymał relikwie św. Wawrzyńca, k. 377-377v.

${ }^{111}$ Jest to karta rozpoczynająca bardzo obszerne odpowiedzi dotyczące poszczególnych kościołów, a także licznych dodatków w postaci dokumentów dotyczących tych parafii. Karta 361 częściowo uszkodzona przez wydarcie fragmenty tekstu.

${ }^{112}$ Te odpowiedzi, ze względu na ich szczegółowy charakter mogły być spisane, z dużym nakładem czasu, przez miejscowego duszpasterza, znającego dobrze tak teren, jak i dokumentacje dotycząca parafii. A ponieważ był nim zakonnik cysters, miał dostęp do archiwum w Oliwie. 
67. Opis wyposażenia kościoła w Różynach w paramenty liturgiczne, k. 377v-378 .

68. Przywileje odpustowe kościoła w Różynach, 378.

69-74. Dochody i uposażenie kościoła w Różynach, k. 378.

75. Odpis dekretu reformacyjnego z 15 XI 1765 r., podpisany przez Bartłomieja Trochowskiego ${ }^{113}$, kanonika kruszwickiego, oficjała świeckiego, wizytatora, k. 377-8-378v.

76. Fundacja mszy w kościele w Różynach, przez dawnego proboszcza Marcina Aleks w 1762 r., k. 378v.

$\mathrm{Na}$ karcie ostatniej, która nie jest opatrzona numeracją, indeks parafii w języku niemieckim.

\section{G 82}

\section{A. OPIS KSIĘGI}

[1. Sygn. akt.] G82.

[2. Tytuł nadany] Status ecclesiarum et beneficiorum Decanatus Svecensis anno 1819

[3. Daty krańc.] 1819.

[4. Opis zewn.] Tekst Łacińsko-polski. 36,6 $\times 22,0 \mathrm{~cm}$. Kart paginowanych 42. Karty z różnych papierni. Księga pisana różną ręką, zazwyczaj przez samych proboszczów. Niekiedy atrament zalewał i kłopoty z odczytaniem. Oprawa broszurowa. Karty nie zapisane mają odcięte roki. Karty puste:, 1v, 2v, 6v.10v, 15v, $23 \mathrm{v}, 30 \mathrm{v}, 36 \mathrm{v}, 37 \mathrm{v}, 38,43 \mathrm{v}, 51 \mathrm{v}$,

[5.Uwagi] Proboszczowie mieli przedstawione pytania zebrane według czterech rozdziałów: de ecclesia, de beneficio, de paracho et ministris, de parochanis. Pytania te podano przy opisie parafii Świekatowo i Lubiewo. Poszczególne opisy, czyli odpowiedzi, bardzo różnią się co do formy, a także co szczegółów opisu. Niekiedy spisywali je sami proboszczowie, niekiedy był jedynie ich podpis uwierzytelniający opis. Są podstawowe dane o proboszczach.

Nazwy miejscowości w kilku miejscach trudne do odczytanie. Podawano je w brzmieniu podanym w księdze.

\section{B. ZAWARTOŚĆ KSIĘGI}

Karta tytułowa, a właściwie okładka, z tytułem: Status Ecclesiarum et beneficiorum Decanatus Svecensis anno 1819.

Powtórzenie tytułu oraz wykaz tabelaryczny dekanatu, liczącego 13 parafii, z podaniem najważniejszych danych statystycznych dotyczących poszczególnych parafii, których było 13, k. 1 .

${ }^{113}$ Biogram tego kanonika kruszwickiego zob. Fiutak, Katalog prałatów i kanoników kruszwickich, [rkps w Archiwum Diecezjalnym we Włocławku], s. 116. 
Tekst pisma proboszcza Gruczna, księdza Wojciecha Łakomeckiego, z dnia 12 IX 1819 r., do Konsystorza Generalnego, informujący o wysłaniu niżej umieszczonych opisów kościołów i probostw. Opisy te nadsyłali proboszczowie. Brak opisów z Przysierska, Łąkiego, Śliwic i Osi, bo z nich sprawozdań nie przesłano ${ }^{114}$, k. 2. $1819 \mathrm{r}$.

Stan kościoła parafialnego i beneficjum w Ś w i e c i u. Opis sporządzono 9 IX

Tytuł I de ecclesia. Prawo patronatu należało do króla. Opis sprawowanych nabożeństw. Kościół pod wezwaniem św. Stanisława biskupa i męczennika. Wykaz dni z przywilejem odpustowym. Kościół nie miał zapisanej ziemi, ale wiele zapisów na różnych dobrach, tu wyliczonych. Wyka ogólny dochodów i wydatków. Klucze od tabernakulum są u proboszcza, zaś od skarbony jeden u rządcy parafią, a inne u witrykusów lub kolatora, od kasy natomiast jeden u rządcy, drugi u jednego witrykusa, a trzeci u drugiego witrykusa. Stan archiwum parafialnego Stan zakrystii i jej wyposażenia. Po kradzieży, zakupiono monstrancję, puszkę i kielich. Opis świątyni, murowanej. Cmentarz (grzebalny) dawniej przy kościele, a teraz na przedmieściu, ogrodzony, dla samych katolików, k. 3-4v.

Tytuł II de beneficio. Proboszcz ma na użytek dwa łany ziemi. Spis inwentarzażywegoimartwego. Domplebańskii pięciu pomieszczeniach orazoficynaikuchnia, w stanie dobrym. Wykaz otrzymywanych dziesięcin, k. 4v-5.

Tytuł III de parocho et ecclesiae ministris. Proboszcz, a właściwie zarządca, Józef Prądzyński. Był przy parafii notariusz ${ }^{115}$, Jan Berenta, święcony w 1818 r., otrzymujący stosowne wynagrodzenie. Wikariusz Jozafat Krokowski, też mający odpowiednie uposażenie. Organista Jan Maczewski, zakrystian Karol Kremer. Witrykusi Bartłomiej Rocławski, Augustyn Miernicki, obydwaj mieszczanie ze Świecia, k. 5-5v.

Tytuł IV de parochianis. Ogólna liczna wiernych 1500 osób. Wsie parafialne Przechowo, Orzechówko, Morsk, Gungen, Solnowo, Solnówko, Ostrowo, Kozłowo, Skarszewy, Dziki, Czaple, Czapelki. Liczba Komunikujących 1300 osób. 10 chłopców i 8 dziewcząt tego roku przyjęło Komunię pierwszy raz. Do szkoły chodzi około 100 uczniów. Był jeden nauczyciel katolik i sześciu akatolików. Szpital jeden, w stanie średnim i dom dla chorych w stanie dobrym, obydwa na przedmieściu, obok klasztoru bernardynów. Szkoła odbudowana z funduszy królewskich, stan dobry, k. 5v-6.

Kościół filialny we wsi Ś w i ę t e, prawa patronatu szlacheckiego.

Wymagał naprawy. Pod wezwaniem św. Wojciecha. Nabożeństwo w święto tego patrona i na św. Katarzynę. Był tu domek, zbudowany przez proboszcza Maurzyckiego, ale został spalony przez złych ludzi. W Sartowicach znajdowała się kaplica publiczna, pod wezwaniem św. Barbary, prawa patronatu szlacheckiego, ale wymagała także remontu. Nabożeństwa, w miarę możności, w każdą nie-

\footnotetext{
${ }^{114}$ Zdaje się, że nadesłano je później, bo znajdują się w księdze.

${ }^{115}$ Trudno powiedzieć o kogo chodzi? Może to neoprezbiter?
} 
dzielę i święta. Z tych świątyń korzystało około 250 wiernych z wsi Święte Wielkie, Święta Małe, Sartowice Wielkie, Małe, Górne, Marzy Stare, Marzy Nowe, Mniszek i Michale oraz wsie królewskie Deutz Westfalen, Polisch Westfalen, Bratwin i Neühuben, k. 6.

Powyższe odpowiedzi na pytania sporządził w dniu podanym wyżej Ks. Prądzyński i spisane osobiście podpisał ${ }^{116}, \mathrm{k}$. 6 .

Stan kościoła parafialnego i beneficjum w D r z y c i m i u, k. 7.

Opis ten sporządzono w Drzycimiu w dniu 1 IX 1819 r., k. 8.

Tytuł I de Ecclesia. Prawo patronatu należało do króla. Opis nabożeństw. Świątynia pod wezwaniem Wszystkich Świętych. Wykaz dni odpustowych. Opis uposażenia kościoła. Zawartość zasobu archiwum parafialnego. Stan paramentów liturgicznych oraz opis kościoła, zbudowanego na sposób pruski, wymagającego naprawy. Cmentarz ogrodzony i dla samych katolików, k.8-9.

Tytuł II de beneficio. Dla proboszcza były cztery łany ziemi. Spis inwentarza żywego i martwego. Opis domu plebańskiego, ogrodów i innych zabudowań gospodarczych. Proboszcz miał deputat drewna. Niektóre zabudowania gospodarcze należało naprawić. Podano wielkość pobieranej dziesięciny. Inne źródła dochodów proboszcza, k. 9-9v.

Tytuł III de parocho et ecclesiae ministris. Proboszcz Maciej Kaszubowski, nie mający wikariusza, zawsze na miejscu rezydujący. Organista Maciej Minikowski, spełniający też role organisty. Witrykusi, Jakub Ratkowski i Wawrzyniec Kruczeń, obydwoje z Drzycimia, k. 9v.

Tytuł IV do parochianis. Liczba wiernych 2000. Wsie królewskie Drzycim, Gacki, Grodek, Grodeczek, Grzybek, Lniano, Mursz, Dombrowa, Polka, Ryszka, Rokosz, Sierosław, Sierosławek, Suchom, Wentfie, Ottersteig, i wsie szlacheckie Brzenczek, Brzemiona, Małe Brzemiona, Dombrówka, Dulsk, Grabowa Buchta, Hamer, Juliaanowo, Jastrzębie, Jeziorki, Łysiny, Lnianek, Lutochen, Lopsez, Mszano, Rowienica, Siemkowo, Spławie, Wąsosz, Wyry, Zalesie, Zdunki, Żuławka. Do komunii wielkanocnej było zobowiązanych 1700 osób. Do pierwszej komunii w ostatnim roku przystąpiło 20 chłopców i 36 dziewcząt. Dwóch nauczycieli katolików i czterech akatolików, ale nie mówiono nic o uczniach. Szpital przy kościele, ale bardzo stary, w nim trzech podopiecznych, żyjących z jałmużny. Dwie szkoły katolickie w Drzycimiu i Wentfuiu, ale mają być budowane następne z funduszy rządowych, k. 9v-10.

Powyższe odpowiedzi, w dniu jak wyżej, spisał w Drzycimiu i podpisał zarządzający parafią ksiądz Maciej Kaszubowski, k. 10.

Stan kościoła parafialnego i beneficjum w Przys iersku, spisany 19 IX $1819 \mathrm{r}$.

Tytuł I de ecclesiae. Prawo patronatu królewskie, Opis nabożeństw. Kościół pod wezwaniem św. Wawrzyńca. Wykaz dni odpustowych. Bractwo Różańcowe. Na kościół nie było na uposażenie żadnej ziemi, a tylko zapisy pewnych sum pie-

${ }^{116}$ Tekst spisany inną ręką, ale podpis proboszcza własnoręczny. 
niędzy. Wykaz dochodów. Klucze od tabernakulum i skarbony na plebanii, od kasy u parafian. Spis zawartości archiwum parafialnego. Krótki spis paramentów liturgicznych. Świątynia drewniana, wymagająca nie naprawy, ale odbudowania, k. $11-12 \mathrm{v}$.

Tytuł II de beneficio. Na uposażenie proboszcza dwa łany ziemi. Spis inwentarza. Uposażenie nie wystarczało na godziwe utrzymanie, dlatego postulowano złączenie z parafia i beneficjum w Łąkiem [Polskim], jak to dawniej było, k. 12v13.

Tytuł III de parocho et ecclesiae ministris. Proboszcz Maciej v. Nawoz Wojsa$\mathrm{cki}^{117}$. Rezydował na miejscu i nie miał wikariusza. Organista Ignacy Schmidl, będący jednocześnie zakrystianem. Witrykusi Wojciech Kierkowski i Szymom Wojdel, k. 13-13v.

Tytuł IV de parochianis. Liczba wiernych 434. Wieś królewska Przysiersk i wsie szlacheckie Konopa Polski, Teresdole, Drozdowo, Gawroniec, Bukowiec, Papiernia, Bramsk, Pniewno, Biechowo, Kawęczyn, Biechówko, Budin i Jastrzębieniec. Do komunii wielkanocnej było mężczyzn 294 i kobiet $246^{118}$. Do pierwszej komunii było 11 chłopców i 13 dziewcząt. Dzieci zdolnych do szkoły było około 48. Szkoły katolickie w Przysiersku i Biechówku. Szkoły akatolickie w Bukowcu i we wsi Wielki Konopa. Wierni ze wsi Poledno chodzą do Gruczna, bo jest im wygodniej. W przytułku, który miał pewne uposażenie, przebywały cztery osoby, k. 13v-14v.

Odpowiedzi powyższe spisał i osobiście podpisał Proboszcz [Maciej] v. Nawoz Wojsacki w dniu 19 IX 1819 r., k. 14v.

Stan kościoła parafialnego i beneficjum we wsi P o lsk i e $Ł$ ąki,k. 15.

Opis ten sporządzono 19 IX 1819 r., k. 16.

Tytuł I de ecclesia. Prawo patronatu należało do króla. Opis nabożeństw. Świątynia pod wezwaniem św. Bartłomieja. Wykaz dni odpustowych. Opis uposażenia świątyni. Nie było ziemi, ani zapisanych funduszy. Klucze os tabernakulum przechowywano w zakrystii, a od skarbony u witrykusów. W archiwum księgi od 1760 r. Wykaz paramentów liturgicznych, bardzo skromny. Kościół drewniany, wymagający pilnej odbudowym a nie remontu. Cmentarz obok kościoła dla samych katolików, k. 16-16v.

Tytuł II de beneficio. Proboszcz na utrzymanie miał cztery łany ziemi. Spis inwentarza oraz stan zabudowań plebańskich. Podano wiadomości o dziesięcinach. Spis inwentarza żywego. Zdaniem proboszcza beneficjum to nie wystarczało do należytego utrzymania, k. 16v-17.

Tytuł III de parocho et ecclesiae ministris. Proboszcz Antoni Smoczyński, rezydujący stale na miejscu. Wikariusza nie było. Organista Kazimierz Dignatowski. Witrykusi Paweł Jaworski i Jan Krzywiński, k. 17.

Tytuł IV de parochianis. Wiernych było 220 osób. Wisie królewskie Łąkie i Różanna oraz wsie szlacheckie Gołuczyce, Łączki, Branica i Korytowo. Spowia-

${ }^{117}$ Lekcja niepewna. Pisał sam Proboszcz.

${ }^{118}$ Liczby te nie zgadzają się z podaną wyżej liczbą ogólną katolików. 
dającychsiębyło 22oosób ${ }^{119}$. Do pierwszej komuniiostatniobyło 3 chłopcówi4dziewczęta. Do szkoły uczęszczało 20 uczniów. Na terenie parafii był jeden nauczyciel katolik i 3 akatolików. Publicznych gorszycieli i grzeszników nie było, k. 17-17v.

Odpowiedzi te, spisane w dniu jak wyżej, podpisał osobiście Proboszcz Smoczyński, k. $17 \mathrm{v}$.

Stan kościoła parafialnego i beneficjum w G r u c z n i e, k. 18.

Sprawozdanie to spisano 2 IX 1819 r., k. 18v.

Tytuł I de ecclesia. Prawo patronatu należało do kolegium wikariuszy z Gniezna. Opis sprawowanych nabożeństw. Patronem parafii był św. Jan Chrzciciel. Wykaz dni odpustowych. Bractwo św. Aniołów Stróżów, k. 18-19. Parafia nie posiadała ziemi, ale były pewne zapisy. Podano dochód i wydatki. W archiwum metryki od $1670 \mathrm{r}$ oraz inne księgi. Zakrystia wyposażona w paramenty potrzebne do liturgii. Świątynia murowana, wieża drewniana, wymagały naprawy. Cmentarz w 1815 r. na nowo ogrodzony, jedynie dla katolików, k. 18v-19v

Tytuł II de beneficio. Na uposażenie proboszcza były 4 łany ziemi. Wykaz inwentarza. Zabudowania plebańskie. Wykaz dziesięcin. Wystarczało to na utrzymanie jednego kapłana, k. 19v-20.

Tytuł III de parocho et ecclesiae ministris. Proboszcz Wojciech Łukomecki, rezydujący na miejscu. Wikariusza nie było. Organista Jan Chełkowski, spełniający także role zakrystiana. Witrykusi Fabian Buchholz, Józef Andrzejewski i Jakub Sobiechowski, wszyscy z Gruczna, k. 20.

Tytuł IV de parochianis. Wiernych było 660 osób. Wsie parafialne królewskie: Gruczno, Dworzysko, Kossowo, Krystkowo, Niedźwiedź, Lisszkowo, wsie szlacheckie Poledno, Więckowo, Bagniewo, Matyciechowo, Parlin, Żurowo, Liszkówko. Komunikujących ogółem 553 osoby, z czego mężczyzn 270 i kobiet 283. Do pierwszej Komunii w ostatnim roku przystąpiło chłopców 11, zaś dziewcząt 15. Dzieci zdolnych do szkoły w parafii było 85 , a uczęszczało 80 . Nauczyciel katolik 1, a akatolików 4. Publicznych gorszycieli nie było. Szpital przy kościele nowy, poprzedniego roku przez proboszcza odbudowany, a w nim 3 podopiecznych, żyjących z jałmużny. Szkoła katoliczka w Grucznie, akatolickich szkól było 4, k. $20-20 \mathrm{v}$.

Odpowiedzi te sporządzone zostały przez samego proboszcza Wojciecha Łakomeckiego i przezeń podpisane, k. 20v.

Stan kościoła parafialnego i beneficjum w S e r o c k u. Opis sporządzono 29 VIII 1819 r., k. 21.

Tytuł I de ecclesia. Prawo patronatu należało do króla. Opis nabożeństw. Kościół pod wezwaniem Niepokalanego Poczęcia Najświętszej Marii Panny. Wykaz dni odpustowych. Bractwo Różańcowe. Parafia nie posiadała ziemi, ale były pewne zapisane kapitały. Klucze kościoła znajdowały się na plebanii, od tabernakulum w zakrystii, a od skarbony u witrykusów. W archiwum parafialnym księgi metryk od 1665 r. oraz wiele innych materiałów archiwalnych. Zakrystia wyposa-

${ }^{119}$ Nie zgadza się to według ogólnej liczby wiernych. 
żona w to, co potrzebne. Świątynia parafialna nowa, murowana, w stanie dobrym. Cmentarz ogrodzony murem kamiennym, dla samych katolików, k. 21-22.

Tytuł II de beneficio. Proboszcz miał 4 łany ziemi. Spis inwentarza. Plebania wymagała naprawy, i byłoby lepiej, żeby przy nowym kościele i ta była nowa. Inne zabudowania gospodarcze. Ogólna ilość pobieranych dziesięcin. Za obecnego proboszcza wybudowano nowy kościól, a także nowy spichrz, k. 22.

Tytuł III de parocho et ecclesiae ministris. Proboszcz Józef Prądzyński, dziekan dekanatu świeckiego, wikariatu apostolskiego ${ }^{120}$. Miał przy parafii zarządce Wojciecha Gosienieckiego, ponieważ sam rezydował w Świeciu. Organista Tomasz Szymański, będący także zakrystianem. Witrykusi Wojciech Rosiecki i Marcin Szczygielski, k. 22v.

Tytuł IV de parochianis. Liczba akatolików wynosiła 650 osób we wsiach królewskich Serock, Stary i Nowy Jasieniec, osada młyńska Kręgiel i Jasieniec, Glinki, Corplewo, Pustkowia Korpiszewo, Wątrobowo, Szukaj, Radzinek, Piaseczno i Wielonek oraz wsie szlacheckie Łaczewo, Łowin, Nieciszewo, Brzeźno, Łowinek i Pustkowia Pasieka, Lubanie i Lipiny. Liczba komunikujących 600. W ostatnim roku do pierwszej Komunii przyjęto 8 chłopców i 7 dziewcząt. Dzieci uczęszczających do szkoły było 106. Był 1 nauczyciel katolik i 5 akatolików. Do kościoła parafialnego w Serocku chodzili także z innych parafii. Publicznych grzeszników nie było. Szpital wymagał odbudowania, k. 22v-23.

Odpowiedzi powyższe podpisał sam Proboszcz Prądzyński, k. 23.

Stan kościoła parafialnego i beneficjum w Ś w i e k a to w i e, co spisano dnia 8 VIII $1819 \mathrm{r}$.

Tytuł I de ecclesia. Kolatorem był król. Porządek nabożeństw. Kościół pod wezwaniem św. Marcina. Wykaz dni odpustowych. Bractwo Opatrzności Bożej i Szkaplerzne. Na uposażenie parafii 1 łan ziemi. Żadnych domów nie było. Był pewien zapis. Dochód i rozchód. Klucz od tabernakulum przechowywany w kościele, zaś od kościoła i skarbony u proboszcza. W archiwum parafialnym księgi metryk od 1802 r. oraz inne materiały. W zakrystii wszystko, co potrzebne. Świątynia drewniana, wymagająca całkowitej odbudowy. Na cmentarzu przy kościele chowają się jedynie katolicy, k. 24-25.

Tytuł II de beneficiis. Dla proboszcza były 4 łany ziemi, uprawiane przez dzierżawcę, za zgodą konsystorza foralnego. Wykaz inwentarza. Plebania z funduszy kolatora - króla i staraniem aktualnego proboszcza odbudowana jako murowana o 4 pomieszczeniach. Wielkość pobieranej dziesięciny. Do wystarczającego utrzymania proboszcza potrzeba przyłączenia kościoła w Łąkiem, k. 25-25v.

Tytuł III de parocho et ecclesiae ministris. Proboszcz Józef Kalicki, rezydujący na miejscu, ale nie było wikariusza. Organista Marcin Karowski. Nie było zakrystiana i kalkancisty. Witrykusi Baltazar Hylka i Antoni Piotrowski, k. 26.

Tytuł IV de parochianis. Wiernych było 408. Wsie parafialne królewskie Świekatowo, Błądzin, Zalesie, Lipienica, Gruenfelde, Brunstplatz i Baërenthal. Wsie szlacheckie Łąkie, Tuszyny, Szewno, Wyrembki, Szewienek, Krupocin, Os-

${ }^{120}$ Było to bowiem po bulli Ex imposita Nobis, a przed bullą De salute animarum. 
trowite, Huta, Sowieniec, Zacisze, Słempiska i osada młyńska Młyn łącki. Dawniej do parafii tej należały wsie szlacheckie Branica i Stążki, ale teraz należą do parafii Łąki (Polskie). Spowiadało się 191 mężczyzn i 217 kobiet. Ostatniego roku pierwszą Komunię przyjęło 10 chłopców i 11 dziewcząt. Do szkoły powinno uczęszczać 82, a chodziło 60 dzieci katolików. Było 2 nauczycieli katolików i 4 akatolików. Szpitala nie ma, ponieważ się spalił, ale ma być odbudowany. Szkoła nowa, murowana i w dobrym stanie. K. 26-26v.

Powyższe wiadomości spisał w dniu 8 VIII 1819 r. zarządzający parafią ks. $\mathrm{Kalicki}^{121}$, k. 26v.

Stan kościoła parafialnego i beneficjum w Lubiewie. Opisano to dnia 26 VIII $1819 \mathrm{r}$.

Tytuł I de ecclesiae. Prawo patronatu dawniej należało do kapituły gnieźnieńskiej, obecnie do rządu. Opis nabożeństw sprawowanych w świątyni parafialnej, a także katechizacji. Patronem świątyni jest św. Mikołaj. Wykaz innych dni odpustowych. Klucze od tabernakulum i świątyni przechowuje rektor ${ }^{122}$ kościoła, zaś od skarbony Witrykusi. Księgi metryk od 1793 r. Są też księgi dochodów i wydatków. Zakrystia wyposażona $\mathrm{w}$ to, co niezbędne. Podano również nowe nabytki poczynione przez obecnego proboszcza. Świątynia drewniana, zbudowana w 1792 r. przez parafian, naprawiana w 1812 r. i obecnie znajdowała się w stanie dobrym. Cmentarz przykościelny ogrodzony, a chowają się tu jedynie katolicy, k. 27-28v.

Tytuł II de beneficio. Proboszcz ma na utrzymanie 3 łany ziemi. Podano ile wysiewa ziarna. Spis inwentarza gospodarczego. Opis zabudowań i ogrodów plebańskich. Na opał proboszcz nie ma wolnego wyrębu, ale deputat roczny. Proboszcz wystawił nowy dom drewniany dla służby plebańskiej. Podano dochody z dziesięcin i z Kolendy. Aktualny proboszcz dbał o stan beneficjum. Uwagi na temat, co robić, aby podnieść dochody proboszcza do stanu wystarczającego, $\mathrm{k}$. $2 \mathrm{v}-29$.

Tytuł III de parocho et ecclesiae ministris. Proboszcz Paweł Ksawery Okoniewski, zawsze rezydujący na miejscu. Organista Wojciech Sieracki, bedacy zarazem zakrystianem. Witrykusi Michał Pronobis, Maciej Stencel oraz filip Jędryczka, k. 30v.

Tytuł IV de parochanis. Wiernych ogółem 920 osób, ze wsi Lubiewo, Klonowo, Sucha i Trutowo. Do komunii wielkanocnej było 830 osób, z czego mężczyzn 390 i kobiet 440/ Do pierwszej komunii chłopców 12, dziewcząt 16, czyli razem 28. Dzieci nadających ssie do szkoły ogółem 120, a uczęszczało 99. Dwóch nauczycieli katolików w Lubiewie i Suchej, w Klonowie akatolik. Parafianie uczęszczali do swojego kościoła parafialnego. Publicznych grzeszników nie było. Nie było przytułku, chociaż ubogich było wielu, ale parafianie wzbraniają się go wybudować. Szkoła dwie w 18`17 r. wybudowane w Lubiewie i Suchej, częściowo z funduszy rządowych, częściowo przez parafian, k. 29v-30.

\footnotetext{
${ }^{121}$ Wyżej był nazwany proboszczem.

${ }^{122} \mathrm{~W}$ tym protokole używa się zamiennie określenia rektor i proboszcz.
} 
Odpowiedzi na stawiane pytania sformułował i osobiście podpisał w Lubiewie, w dniu wyżej podanym, rządca parafia Paweł Ksawery Okoniewski, k. 30.

Stan kościoła parafialnego w Bysławiu i jego beneficjum, spisany w Bysławiu w dniu 1 IX 1819 r.

[Tytuł I] Prawo patronatu należało do króla. Opis nabożeństw w kościele parafialnym. Kościół pod wezwaniem Przemienienia Pańskiego. Bractwo Różańcowe. Parafia nie posiadała na swoje uposażenie ziemi, czy domów, ale zapis 400 florenów na dobrach Brzozie. Dochody i wydatki parafialne. Klucz od tabernakulum przechowywany w kościele, od kościoła u proboszcza, a od skarbony u witrykusów. Księgi metryk od $1711 \mathrm{r}$. W archiwum parafialnym jeden dokument dla kościoła i wsi jeszcze z czasów krzyżackich. Była księga zarządzeń władzy duchownej i świeckiej - zawsze spisywanych. Stan paramentów liturgicznych w zakrystii. Swiątynia murowana przezponad 500laty,jeszcze przezKrzyżaków.W 1816 r. naprawiany przez aktualnego proboszcza. Cmentarz ogrodzony, dla samych katolików, k. 31-32v.

Tytuł II de beneficio. Proboszcz miał 5 łanów miary magdeburskiej. Inwentarz gospodrczy, Stan zabudowań plebańskich. Utrzymanie dla proboszcza „mizerne”, k. $32 \mathrm{v}-33$.

Tytuł III de parocho et ecclesiae ministris. Proboszcz Józef Poperski ${ }^{123}$, zawsze tu rezydujący. Wikariusza na miejscu nie było, ale był przy kaplicy filialnej. Organista Bonawentura Poperski. Witrykusi Jakub Szwidawski i Kazimierz Szwidawski oraz Andrzej Zwiewka, k. 33v.

Tytuł IV de parochianis. Ogółem parafian 100 we wsiach Bysław Duży, Bysław Mały, Mnichowo, Piła, Szumiąca, Ruda, Platowo, Dziki, Płatka, Iwick, Wysoka, Wełpin, Wierzchlas i Byszewa. Na Wielkanoc spowiadało się 380 mężczyzn i 400 kobiet. Do pierwsze komunii przystapiło 18 chłopców i 20 dziewcząt. Dzieci szkolnych było około 80, ale do szkoły chodziło około 60. Akatolików razem z dziećmi na terenie parafii było około 60 osób. Do kościoła parafialnego chodzili wszyscy, z wyjątkiem mieszkańców Minichowa i Bysławia.. Nie było publicznych grzeszników. Szpitala nie było. Szkoła ma być odbudowana z funduszy rządowych, k. 33v-34v.

Odpowiedzi sporządził i własnoręcznie podpisał proboszcz Józef Poperski, k. $34 \mathrm{v}$.

Stan kościoła filialnego i beneficjum w Ce k c y ni e. Odpowiedzi spisane 7 IX 1819 r., k. 35.

[Tytuł I.] Prawo patronatu należało do króla. Opis porządku nabożeństw, Kościół drewniany, naprawiany staraniem proboszcza w 1816 r,. od podstaw, k. 35 .

Tytuł II de beneficio. Na uposażenie 5 łanów ziemi miary magdeburskiej. Zabudowania gospodarcze. Łąka zwana Baba i las odzyskane przez proboszcza droga procesowa. Utrzymanie mizerne, ale trudno powiedzieć, jak to naprawić, k. 35.

${ }^{123}$ Lekcja niepewna. Pismo bardzo nieczytelne, tak w odniesieniu do parafii Bysław, jak i kościoła filialnego w Cekcynie. 
Tytuł III [de parocho et ecclesiae ministris] Ignacy Chmielewski, zarządca ${ }^{124}$. Organista Jan Zieliński. Witrykusi Maciej Szyszkowski i Jakub Jazlak, k. 35v.

Tytuł IV de parochianis. Ogółem wiernych około 900. Wsie: Cekcyn, Wichobertyn, Brzozie, Zielonka, Gnina Małe, Mikołajskie, Budziska Wielkie, Budziska Małe, Krzywogonica, Olnisk, Bielska Struga, Folusz, Saminy, Nalewick, Zalesie, Koryta i Zamatre. Do spowiedzi wielkanocnej mężczyzn 380, a kobiet 390. dzieci do pierwszej komunii chłopców 22 i dziewcząt 20. dzieci zdolnych do nauki około 70, a uczyło się około 40. Akatolików mieszkało na Terenia parafii około 100 osób, k. 35v-36.

Podpisał te odpowiedzi proboszcz Poperski, k. 36.

Pismo księdza Łakomeckiego z Gruczna, do Wikariatu Apostolskiego z wiadomością że przesyła nadesłane mu sprawozdania z parafii Łąkie, Śliwice i Przysiersk. Skarży się, że nie nadesłał jeszcze sprawozdania proboszcz parafii Osie, ks. Sollochowicz, znany z tego, że nigdy nie spełnia poleceń władzy. Pod tym pismem zarządzenie wydane w Gdańsku 13 X 1819 r., skierowane do ks. Sollochowicza, aby w nieprzekraczalnym terminie 14 dni nadesłał sprawozdanie, k. 37.

Stan kościoła parafialnego i beneficjum w Ś 1 i w i c a c h, k. 38v.

Spisano to sprawozdanie w rezydencji plebańskiej w Śliwicach, dnia 2 IX $1819 \mathrm{r}$.

Tytuł I. Prawo patronatu należało do króla. Opis nabożeństw. Kościół pod wezwaniem św. Katarzyny. Wykaz dni odpustowych. Parafia posiadała dokumenty dotyczące przywilejów odpustowych. Było bractwo, ale nie podano jego imienia. Nie było ziemi parafialne, a jedynie niewielki zapis 150 florenów. Klucze od tabernakulum i kościoła przechowywał Proboszcz, zaś od skarbony Witrykusi. Księgi metryk rozpoczynały się od 1670 r. Dokumenty, jakie dawniej się znajdowały na plebanii, spaliły się. Prowadzono księgę do zapisywania rozporządzeń władzy kościelnej i cywilnej. Krótki wykaz paramentów liturgicznych znajdujących się w zakrystii. Świątynia parafialna drewniana z 1600 r., wymagająca naprawy. Wnętrze przedstawiało się dobrze, k. 39-39v.

Tytuł II de beneficio. Na utrzymanie proboszcza były 4 łany, Wykaz zasiewów. Ziemia ta uprawiana jest przez dzierżawców, którzy $\mathrm{V}$ ja na jeden rok. Proboszcz miał deputat drewna i prawo wspólnego pastwiska. Pobierał także dziesięcinę. Spis inwentarza żywego. Opis domu plebańskiego i zabudowań gospodarczych. Aktualny Proboszcz zbudował nowa plebanię oraz inne budynki. Dochód wystarcza na utrzymanie proboszcza, ale bez wikariusza, k. 39v-40.

Tytuł III de parocho [et ecclesiae ministris] Proboszcz Karol Ściniawski. Wikariusza nie było. Organista Karol Wejznerowski. Witrykusi Bartłomiej Czarnocki Andrzej Sikora, k. 40-40v.

Tytuł IV de parochianis. Katolików ogółem około 2000 osób. Wsie parafialne: Śliwice, Śliwiczki, Laski, Zazdrość, Łążek, Łęski Piec, Zdroje, Łisiny, Jabłonki, Kamionki, Brukniewo, Gacna, Koniny, Główka, Biała, Bielska Struga, Klocek,

${ }^{124}$ Parafia ta zarządzana była częściowo przez proboszcza z Bysławia, bo jak inaczej wytłumaczyć, że protokół ten przez niego został sporządzony i podpisany. 
Zegec, Woziwoda, Rzepich, Rosochata, Krąk, Lipowa, Włochi, Szlachta, Oszewek, Starzyska, Osieczna, Krowna, Zdrojno, Brzezno, Linowek, Lubocień, Lińsk, Koniny, Przepciny. Do spowiedzi wielkanocnej było 1009 mężczyzn i 861 kobiet, do pierwszej Komunii 14 chłopców i 15 dziewcząt. Dzieci zobowiązanych do szkoły naliczono około 200 , ale uczęszczało 80 . Nie było publicznych grzeszników. Nie było przytułku, a ubodzy żyli u patafian. Włóczęgów nie było. Cztery szkoły zbudowane z funduszy rządowych, k. 40v.

Odpowiedzi powyższe sporządził i podpisał zarządca Ścinawski, k. 40v.

Stan kościoła parafialnego i beneficjum w J e ż e w i e. Spisano dnia 30 VIII $1819 \mathrm{r}$.

[Tytuł I] Prawo patronatu należało do króla. Opis sprawowanych nabożeństw w kościele parafialnym oraz dni odpustowych. Świątynia pod wezwaniem Świętej Trójcy. Bractwo Świętej Trójcy. Na uposażenie kościoła był las z 8-mioma pniami pszczelimi, a także pewne zapisy lokowane na dobrach szlacheckich Laskowice, Belno, Maszewo, Jaszcz i Lipinki. Wykaz dochodów z pogrzebów oraz rozchodów. Klucze od tabernakulum i świątyni przechowywane były u proboszcza, zaś od skarbony u dwóch Witryłów. Metryki od 1752 r. Księgi rachunkowe znajdowały się u Witryłów i rzadko były sprawdzane przez dziekana. Księgę zarządzeń prowadzono. Zakrystia posiadała wszystko, co konieczne. Wyliczono nowe nabytki poczynione przez aktualnego proboszcza. Prezbiterium kościoła murowane, zaś nawa drewniana, ale ich stan zagrażał nawet bezpieczeństwu. Na cmentarzu chowali się sami katolicy, k. 41-41v.

Tytuł II de beneficio. Na utrzymanie proboszcza było 5 łanów ziemi, uprawianych przez dzierżawców. Niewielki inwentarz gospodarczy. Plebania wymagała odbudowania. Był pewien deputat na drewno z lasu oraz prawo wolnego wypasu zwierząt. Proboszcz miał też 4 domy, w jednym mieszkał organista i ubodzy, a w trzech lokatorzy. Wykaz dziesięcin. Beneficjum to, zdaniem proboszcza nie wystarczało na godziwe utrzymanie, k. 42.

Tytuł III de parocho et ecclesiae ministris. Proboszcz Wincenty Węsierski. Wikariusza nie było. Organista Jan Kalicki. Zakrystiana nie było. Witrykusi Fabian Gackowski i Walenty Zaremba, k. 42-42v.

Tytuł IV de parochianis. Liczby wiernych Proboszcz nie umiał podać, ponieważ był dopiero od poprzedniego roku w parafii. Wsie parafialne: Belno, Buzek, Bedlenek, Białe, Buszna, Busienki, Borce, Cersk, Dąbrowa Jeżewska, Długoleszcz, Huta, Jeżewo, Jaszcz, Kraplewice, Kotowka, Laskowice, Lipna, Lipinki, Łęgowo, Nowawieś, Osłowo, Piskurk, Maszewo, Zaszewko, Węglarka, Wymysłowo, Wężownice. Wiernych komunikujących na Wielkanoc było 620, w tym mężczyzn 301, zaś kobiet 319. Do pierwszej Komunii przystąpiło ostatniego roku 2 dzieci. Z powodu ubóstwa dzieci nie korzystały z nauki szkolnej. Grzechów publicznych nie było. Szpitala ani szkoły nie było, ale jeden z domów plebańskich był na to przeznaczony, k. $42 \mathrm{v}$.

Powyższe odpowiedzi na pytania sporządził 30 VIII 1819 r. zarządzający parafią ks. Wincenty Węgierski, k. 42v. 